Florida International University FIU Digital Commons

\title{
Determining magmatic processes from analysis of phenocrysts and gabbroic xenoliths contained in Calbuco andesites
}

Tiffany Sperry Horst

Florida International University

DOI: $10.25148 /$ etd.FI15071602

Follow this and additional works at: https://digitalcommons.fiu.edu/etd

Part of the Geology Commons

\section{Recommended Citation}

Horst, Tiffany Sperry, "Determining magmatic processes from analysis of phenocrysts and gabbroic xenoliths contained in Calbuco andesites" (2007). FIU Electronic Theses and Dissertations. 2007.

https://digitalcommons.fiu.edu/etd/2007 
FLORIDA INTERNATIONAL UNIVERSITY

Miami, Florida

DETERMINING MAGMATIC PROCESSES FROM ANALYSIS OF PHENOCRYSTS AND GABBROIC XENOLITHS CONTAINED IN CALBUCO ANDESITES

A thesis submitted in partial fulfillment of the requirements for the degree of

MASTER OF SCIENCE

in

GEOSCIENCES

by

Tiffany Sperry Horst 
To: Interim Dean Mark Szuchman College of Arts and Sciences

This thesis, written by Tiffany Sperry Horst, and entitled Determining Magmatic Processes from Analysis of Phenocrysts and Gabbroic Xenoliths Contained in Calbuco Andesites, having been approved in respect to style and intellectual content, is referred to you for judgment.

We have read this thesis and recommend that it be approved.

Fidel Costa Rodriguez

Grenville Draper

Andrew Macfarlane

Rosemary Hickey-Vargas, Major Professor

Date of Defense: February 16, 2007

The thesis of Tiffany Sperry Horst is approved.

Interim Dean Mark Szuchman

College of Arts and Sciences

Dean George Walker

University Graduate School

Florida International University, 2007 


\section{ACKNOWLEDGMENTS}

I wish to thank my Advisor, Dr. Rosemary Hickey-Vargas, for every aspect of her support and patience throughout the years which I have spent working on this project. Throughout this time she has supported me both intellectually and financially, and has also been a source of moral support. I have truly enjoyed working with her on both a professional and personal level.

I also wish to thank my committee members, Dr. Fidel Costa-Rodriguez, Dr. Grenville Draper, Dr. Andrew Macfarlane, and Dr. Gautam Sen, for their suggestions, corrections, guidance, help, and (seemingly incessant) question answering, without which completion of this project would have been quite difficult.

Special appreciation and thanks go to the staff of FCAEM, Tom Beasley, and Barbara Maloney, for teaching me and allowing me to use the electron microprobe, which has been an integral tool in completion of this project. I wish to thank Dr. Haggerty for his answers to my questions and willingness to help, Tatiana Trejos for her time spent devising a method to analyze my samples with laser ablation ICP-MS, and Dr. Jose Almirall for allowing me use of the machine. I also want to thank Hugo Moreno and Dr. López-Escobar, both from Chile, for sharing their expertise on Calbuco Volcano.

Thanks to all the Earth Science students who have had a hand in this project, Maria Pages for sample preparation, Shaunia Stokes and Judene Tulloch for bulk analysis preparation, and Donna Williams for ICP-ES bulk analysis of the new samples. My thanks also to Melroy Borges and Sedelia Durand for thought provoking scientific 
discussion and answers to my questions and to the rest of the FIU Earth Science department for supporting me and allowing me to pursue my degree.

My appreciation to the National Science Foundation (NSF) for the funding to make this project possible.

Special thanks go to my husband and son, Peter Horst and Brandan McKelvey, for their support and understanding as I worked on this project, and to my parents for their support and love, and to the rest of my family. 


\section{ABSTRACT OF THE THESIS}

DETERMINING MAGMATIC PROCESSES FROM ANALYSIS OF PHENOCRYSTS AND GABBROIC XENOLITHS CONTAINED IN CALBUCO ANDESITES

by

\section{Tiffany Sperry Horst}

Florida International University, 2007

Miami, Florida

Professor Rosemary Hickey-Vargas, Major Professor

Calbuco Volcano, in Southern Chile, has eruptive products of predominantly andesitic hornblende-bearing lava. A purpose of this work is to understand magmatic processes and how Calbuco magma chemistry is related to the explosive volcanic character. Calbuco lava has a mineral assemblage of plagioclase, hornblende, orthopyroxene, clinopyroxene, olivine, and magnetite and entrained gabbroic xenoliths with the same mineral assemblage. The presence of hornblende is evidence for dissolved water in the magma. Detailed petrographic/textural analysis has been done using petrographic microscopy and back-scattered electron imaging (BSE); geochemical analysis by electron microprobe (EPMA). Major findings include 1) that hornblende and hornblende-bearing gabbroic cumulates crystallize from Calbuco magma, 2) that plagioclase grains are compositionally zoned, recording evidence of temperature, chemical, and water content fluctuations in the magma, and 3) that hornblende is unstable under upper magma chamber conditions at Calbuco, and is breaking down into plagioclase, olivine, orthopyroxene, clinopyroxene, and magnetite in the magma. 


\section{TABLE OF CONTENTS}

CHAPTER

PAGE

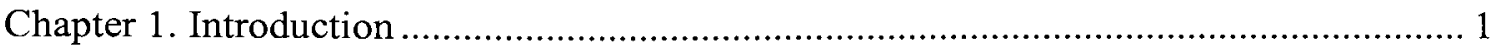

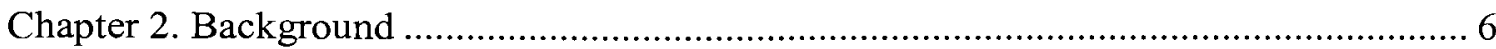

2.1 Andean Volcanic Zones - Geology and Tectonics................................................ 6

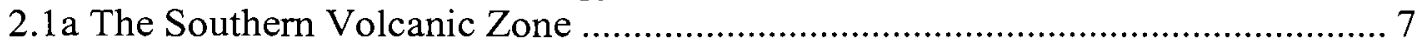

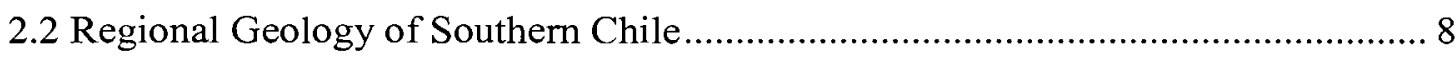

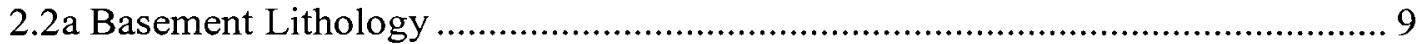

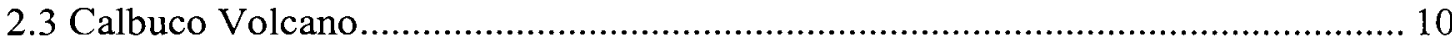

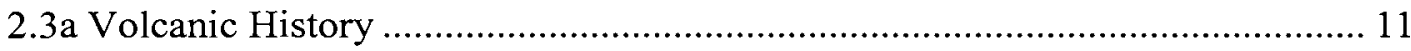

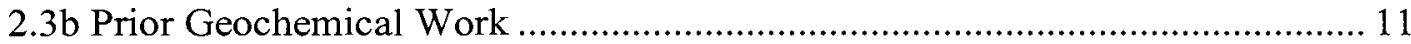

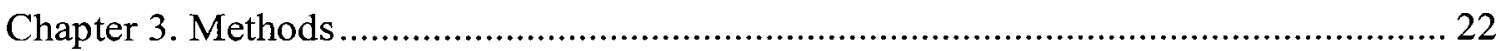

3.1 Sample Collection of New Samples ………......................................................... 22

3.2 Sample Preparation ......................................................................................... 22

3.3 Petrographic Microscope ...................................................................................... 24

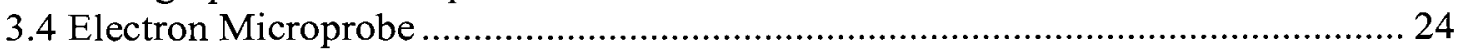

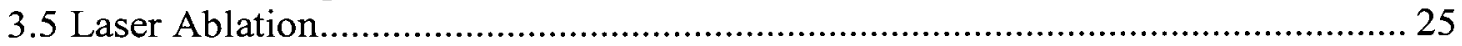

Chapter 4. Chemistry and Petrography of Eruptive Products........................................ 30

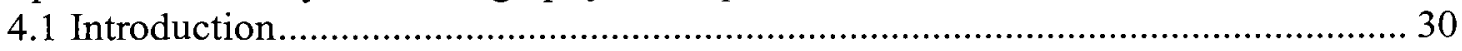

4.2 Whole Rock Chemistry of Newly Collected Samples and Samples

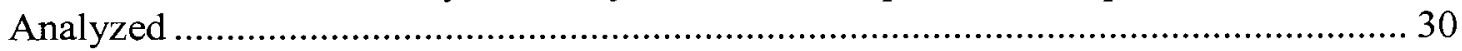

4.3 Mineral Assemblages and Textural Description of Products ................................ 31

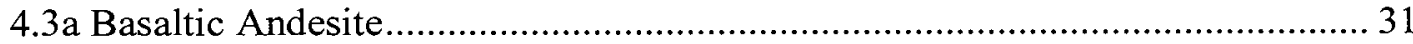

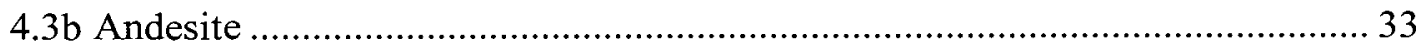

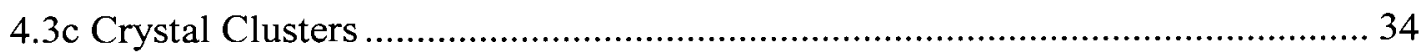

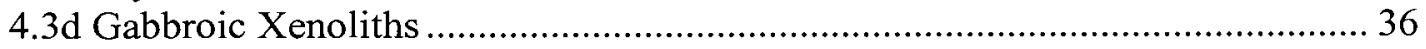

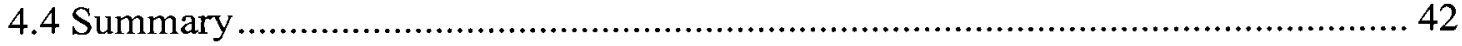

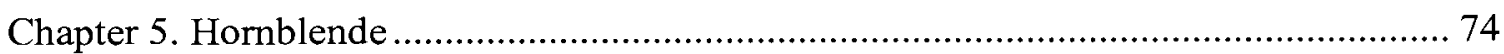

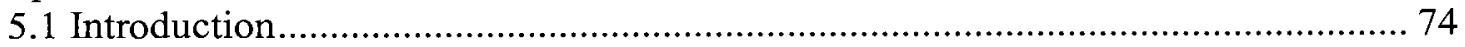

5.2 Hornblende Phenocrysts in the Lava .................................................................... 75

5.2a Textural Description and Mineral Chemistry .................................................. 75

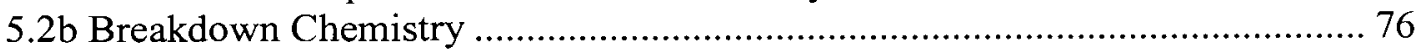

5.3 Hornblende Crystals in the Cumulate Xenoliths .................................................. 77

5.3a Textural Description and Mineral Chemistry ............................................... 77

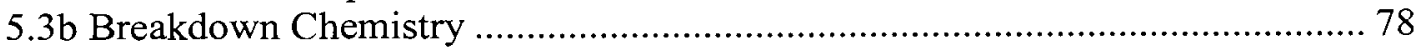

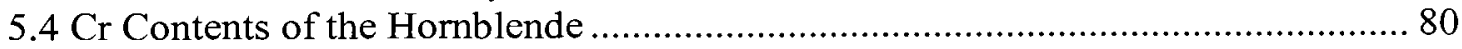

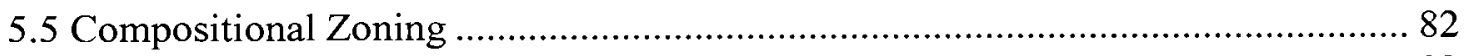

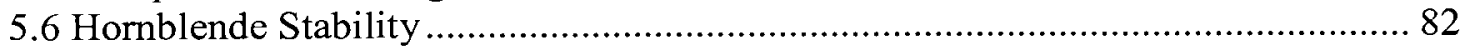

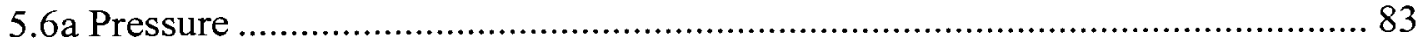




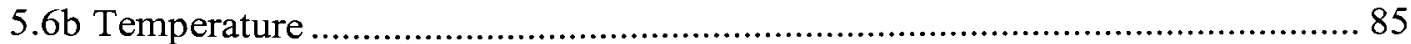

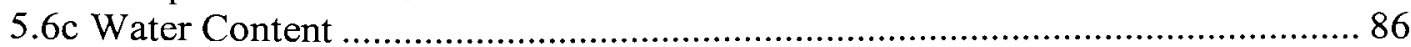

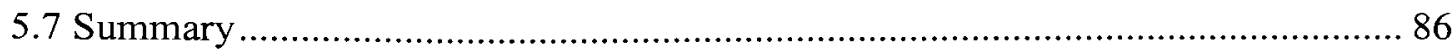

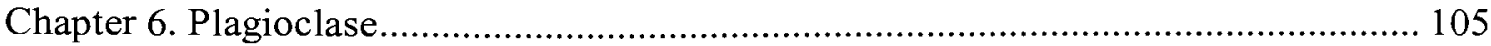

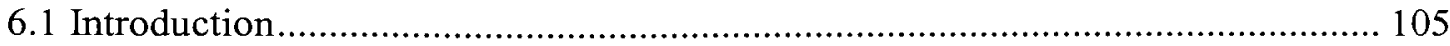

6.2 Crystal Populations and Textural Descriptions ................................................. 105

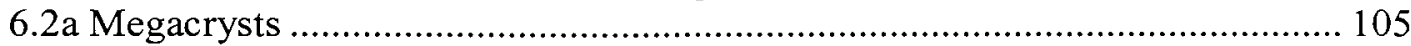

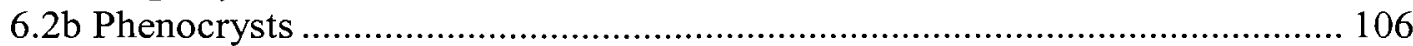

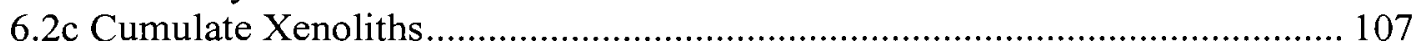

6.2d Crystal Clusters .......................................................................................... 108

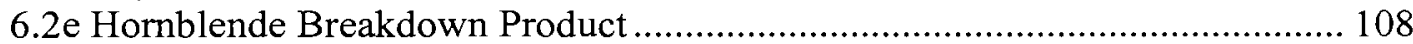

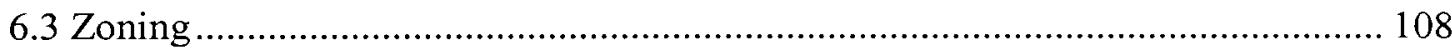

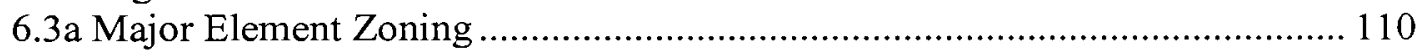

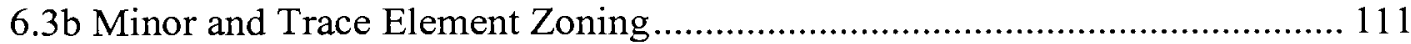

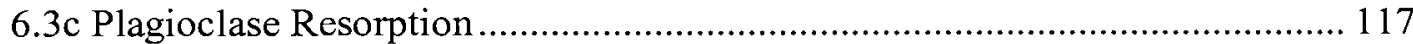

6.3d Plagioclase Growth Zones .......................................................................... 119

6.4 Chemical Composition of Glass Found in Plagioclase........................................ 120

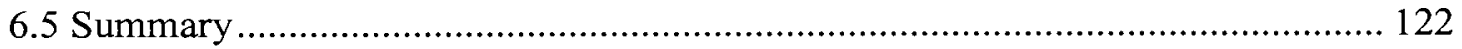

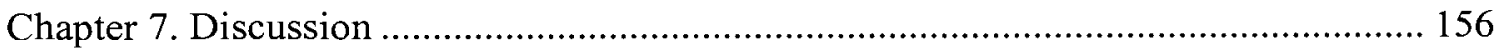

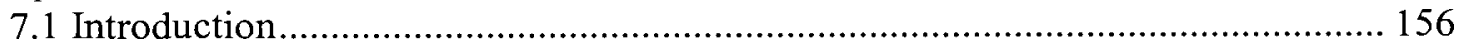

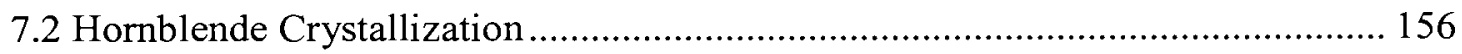

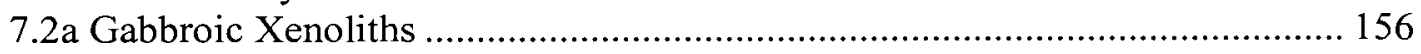

7.2b Hornblende Formation by Primary Crystallization........................................... 158

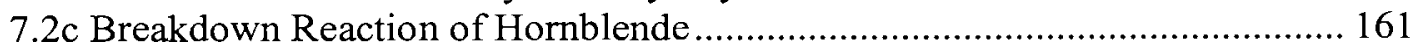

7.3 Changes in Magma Chamber Conditions Recorded in Plagioclase ...................... 166

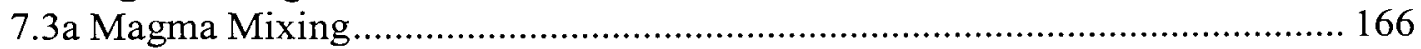

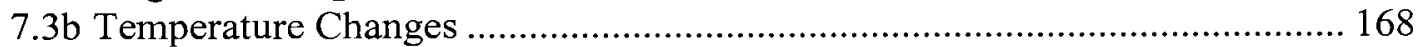

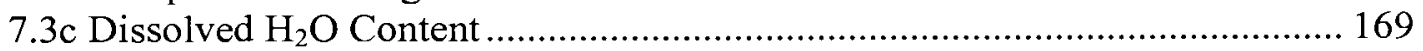

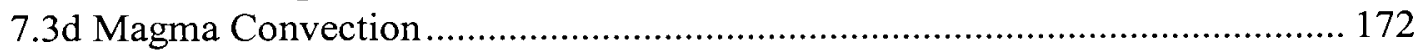

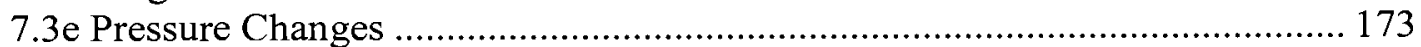

7.3f Equilibrium Crystallization Kinetics .............................................................. 174

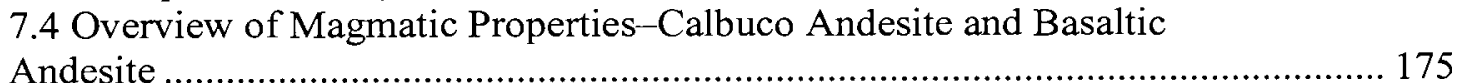

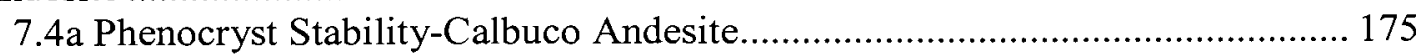

7.4b Phenocryst Stability-Calbuco Basaltic Andesite .......................................... 178

7.4c Magmatic Physical Properties-Calbuco Andesite.......................................... 179

7.4d Magmatic Physical Properties-Calbuco Basaltic Andesite............................. 182

7.4e Physical Properties of Entrained Gabbroic Xenoliths-Calbuco Andesite....... 184

7.4f Physical Properties of Entrained Crystal Clusters-Calbuco Andesite ............. 186

7.4g Physical Properties of Entrained Crystal Clusters-Basaltic Andesite .............. 186

7.4h Volcanic Glass-Calbuco Andesite .......................................................... 186

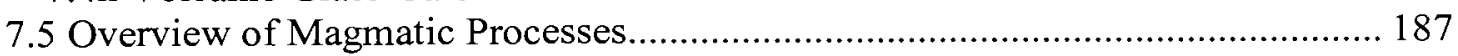

7.5a Crystal Fractionation in Andesitic Magma Chamber..................................... 188 
7.5b Magma Chamber Convection in Andesitic Magma Chamber

$7.5 \mathrm{c}$ Recharge of Andesitic Magma Chamber with Basaltic Andesite

Chapter 8. Conclusions

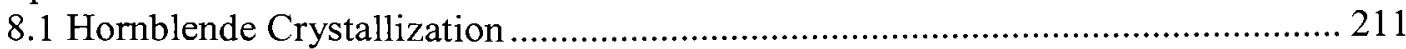

8.1 a Are hornblende-bearing gabbroic xenoliths cognate cumulates? ................... 212

8.2 How does hornblende break down?

8.3 What changes in magma chamber conditions are recorded in plagioclase zoning?

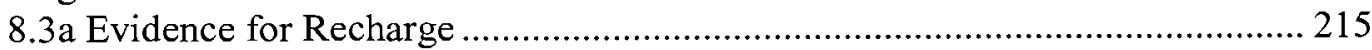

8.3b Evidence for the Presence of Water in the Magma......................................... 216

8.3c Evidence for Magma Chamber Convection .................................................... 218

8.3d Evidence for Recorded Eruption Events .......................................................... 219

8.3f Evidence for Equilibrium Crystallization........................................................ 219

8.4 Synthesis of Calbuco and the Magma Storage Zone ............................................ 219

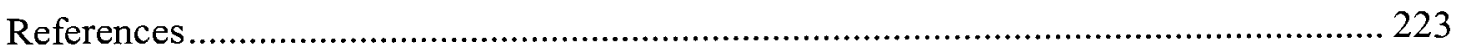

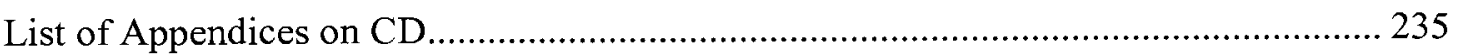




\section{LIST OF TABLES}

TABLE

PAGE

Table 1: Calbuco Samples ..................................................................... 28

Table 2: Major and trace element bulk rock analyses of newly collected samples........ 44

Table 3: Cluster type associations................................................................... 57

Table 4: Hornblende breakdown product associations. ......................................... 91

Table 5: Presence of mineral phases in hornblende breakdown. .............................. 95

Table 6: Calculated Pressure Range. ..................................................... 104

Table 7: $\mathrm{Cr}_{2} \mathrm{O}_{3} \mathrm{wt} \%$ comparison of hornblende and phlogopite............................. 104

Table 8: Point count analysis of andesite...................................................... 128

Table 9: Trace element incorporation into plagioclase....................................... 145

Table 10: Cr concentrations of hornblende........................................................ 194 


\section{LIST OF FIGURES}

FIGURE

PAGE

Figure 1: Geographic map of South America showing the location of Calbuco

Volcano. Map from: www.reliefweb.int/rw/fullMaps 5

Figure 2: Map of South America. 13

Figure 3: East-West transect across Southern Chile.................................................... 14

Figure 4: Map of the Southern Volcanic Zone (SVZ) .............................................. 15

Figure 5: Photographs of Calbuco Volcano.................................................................... 16

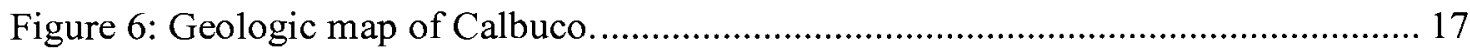

Figure 7: Geologic map of the basement rock near Calbuco.......................................... 18

Figure 8: Stratigraphic section of volcanic products from Calbuco Volcano

(Moreno et al., 2004).

Figure 9: Sr versus Nd isotope plot for Calbuco bulk rock analysis. ............................. 20

Figure 10: $\mathrm{SiO}_{2}$ versus $\mathrm{K}_{2} \mathrm{O}$ plot of gabbroic xenoliths................................................. 21

Figure 11: Map of sample collection sites from IAVCEI 2004 field trip guide...............2 27

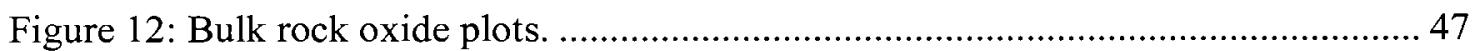

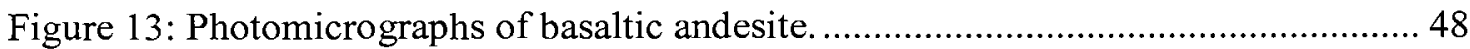

Figure 14: Histogram of An mol\% versus frequency of plagioclase phenocryst cores in basaltic andesite.

Figure 15: Ternary plot showing the composition of orthopyroxene phenocrysts in basaltic andesite.

Figure 16: Ternary plot showing the composition of magnetite phenocrysts in basaltic andesite.

Figure 17: Histogram of Fo mol\% versus frequency of olivine phenocrysts in basaltic andesite.

Figure 18: Basaltic andesite mafic mineral Mg\#. 
Figure 19: Photomicrographs of andesite.

Figure 20: Histogram of An mol\% versus frequency of plagioclase phenocryst cores in andesite samples.

Figure 21: Ternary plot showing the composition of orthopyroxene and clinopyroxene phenocrysts in andesite.

Figure 22: Histogram of Fo mol\% versus frequency of olivine phenocrysts in andesite.

Figure 23: Ternary plot of magnetite phenocrysts in andesite

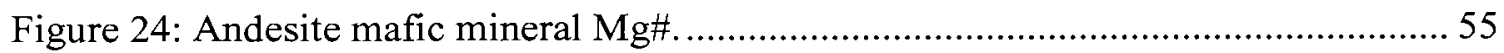

Figure 25: Photomicrographs of crystal clusters. 56

Figure 26: Histogram of An mol\% versus phenocrysts of plagioclase in type $\mathrm{A} 1, \mathrm{~A} 2, \mathrm{~B} 1, \mathrm{~B} 2, \mathrm{C}$, and D crystal clusters.

Figure 27: Ternary plot of orthopyroxene and clinopyroxene grains in type $\mathrm{A} 1, \mathrm{~A} 2, \mathrm{~B} 1$, and $\mathrm{B} 2$ crystal clusters.

Figure 28: Histogram of Fo mol\% versus frequency of olivine grains in type $\mathrm{A} 2, \mathrm{~B} 2$, and $\mathrm{C}$ 63

Figure 29: Ternary plot of magnetite in type A1, A2, B1, and B2 crystal clusters. 63

Figure 30: Crystal cluster mafic mineral Mg\#. 64

Figure 31: Photomicrograph of glass in crystal clusters 64

Figure 32: $\mathrm{SiO}_{2}$ versus $\mathrm{K}_{2} \mathrm{O}$ of bulk glass analyses. .65

Figure 33: Photomicrographs of gabbroic xenoliths. 66

Figure 34: Histogram of An mol\% versus frequency of coarse grained plagioclase in all three gabbroic xenolith samples.

Figure 35: Ternary plot of coarse grained orthopyroxene and clinopyroxene grains in all three gabbroic xenolith samples.

Figure 36: Histogram of Fo mol\% versus frequency of coarse grained olivine in all three gabbroic xenolith samples. 68 
Figure 37: Images of olivine reaction textures.

Figure 38: Ternary plot of coarse grained magnetite and ilmenite in all three gabbroic xenoliths. 70

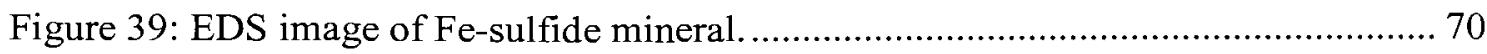

Figure 40: Gabbroic xenolith mafic mineral Mg\#.................................................. 71

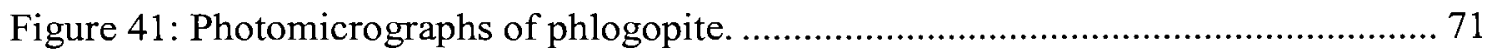

Figure 42: Photomicrographs of interstitial breakdown pockets. .................................... 72

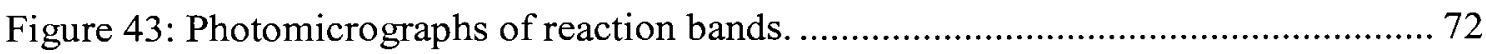

Figure 44: Photomicrographs of glass in gabbroic xenoliths......................................... 73

Figure 45: $\mathrm{SiO}_{2}$ versus $\mathrm{K}_{2} \mathrm{O}$ of glass in gabbroic xenoliths........................................ 73

Figure 46: BSE images of hornblende pseudomorphs............................................... 88

Figure 47: Hornblende phenocryst composition............................................................. 89

Figure 48: Photomicrographs of hornblende phenocryst breakdown

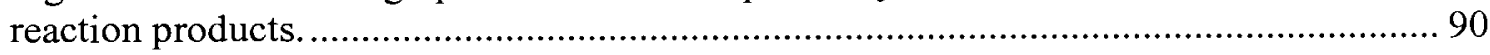

Figure 49: Histogram of plagioclase in hornblende breakdown..................................... 96

Figure 50: Ternary plot of pyroxene in hornblende breakdown..................................... 96

Figure 51: Histogram of olivine in hornblende breakdown.......................................... 97

Figure 52: Ternary plot of oxides in hornblende breakdown. ...................................... 97

Figure 53: $\mathrm{Mg} \#$ of mafic minerals in hornblende breakdown. ......................................... 98

Figure 54: Hornblende composition in gabbroic xenoliths............................................. 98

Figure 55: Photomicrographs of hornblende in gabbroic xenoliths.................................. 99

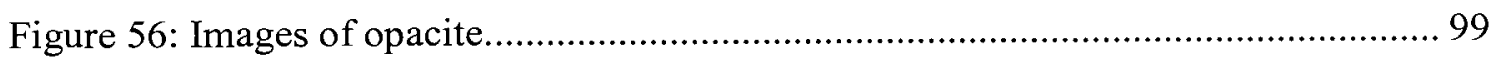

Figure 57: Histogram of plagioclase reaction products in gabbroic xenoliths. 
Figure 58: Ternary plot of pyroxene in gabbroic hornblende breakdown. 100

Figure 59: Histogram of olivine in gabbroic hornblende breakdown. 101

Figure 60: Ternary plot of oxides in gabbroic hornblende breakdown. 101

Figure 61: Andesite and basaltic andesite phase stability diagrams. 103

Figure 62: Photomicrographs of plagioclase megacrysts. 125

Figure 63: Histogram of plagioclase megacrysts. 125

Figure 64: Images of plagioclase phenocrysts. 126

Figure 65: Histogram of plagioclase phenocrysts. 127

Figure 66: Zoned plagioclase in gabbroic xenolith. 130

Figure 67: Photomicrographs of plagioclase in gabbroic xenolith 12-19-18. 130

Figure 68: Photomicrographs of plagioclase in gabbroic xenolith 12-20-8. 131

Figure 69: Photomicrographs of plagioclase in gabbroic xenolith 12-20-3. 131

Figure 70: Transects of plagioclase megacrysts in andesite. 132

Figure 71: Transect of zoned megacryst in andesite. 132

Figure 72: Transect of megacryst in basaltic andesite. 133

Figure 73: Transects of plagioclase phenocrysts in andesite. 133

Figure 74: Transects of plagioclase phenocrysts in basaltic andesite. 134

Figure 75: Reversely zoned transects of plagioclase phenocrysts in andesite and basaltic andesite.

Figure 76: Trace element transects comparing electron microprobe count times.

Figure 77: An mol\% versus. trace element partition coefficients. 137

Figure 78: An mol\% versus. trace element concentrations in plagioclase phenocrysts. 
Figure 79: Trace element transect comparison with An mol\% in andesite.

Figure 80: Trace element transect comparison with An mol\% in basaltic andesite.

Figure 81: Photomicrographs of plagioclase textures................................................... 146

Figure 82: Photomicrographs of volcanic glass in plagioclase................................... 147

Figure 83: Photomicrograph of major plagioclase resorption zones. ........................... 148

Figure 84: Photomicrograph of minor plagioclase resorption zones........................... 148

Figure 85: Plagioclase resorption and growth zones. ................................................. 149

Figure 86: $\mathrm{SiO}_{2}$ versus $\mathrm{K}_{2} \mathrm{O}$ of glass in plagioclase ............................................... 150

Figure 87: $\mathrm{SiO}_{2}$ versus oxides in bulk glass analysis in plagioclase phenocrysts.

Figure 88: $\mathrm{SiO}_{2}$ versus oxides of bulk glass analysis in all plagioclase populations.

Figure 89: Composition of hornblende phenocrysts and from gabbroic xenoliths.

Figure 90: Composition of pyroxene phenocrysts and from gabbroic xenoliths.

Figure 91: Composition of olivine phenocrysts and from gabbroic xenoliths.

Figure 92: Composition of oxide phenocrysts and from gabbroic xenoliths.

Figure 93: Composition of plagioclase phenocrysts and from gabbroic xenoliths.

Figure 94: Mg\# of mafic phenocrysts and gabbroic phases. 193

Figure 95: Volcanic glass in plagioclase and pyroxene, and interstitial glass. 194

Figure 96: Al-Si exchange in hornblende.

Figure 97: Fe-Mg exchange in hornblende. 
Figure 98: Plagioclase liquidus-solidus loop............................................................ 196

Figure 99: Ca-Na exchange in plagioclase phenocrysts and megacrysts. ...................... 198

Figure 100: Ternary Cpx-Ol-Qtz phase diagram....................................................... 199

Figure 101: Ternary Plag-Cpx-Qtz phase diagram................................................. 200

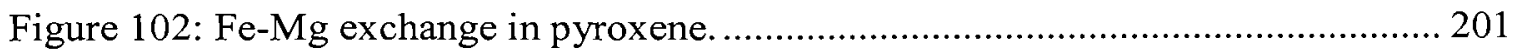

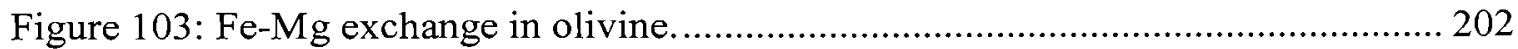

Figure 104: Bulk analysis of glass in plagioclase, pyroxene, and interstitial

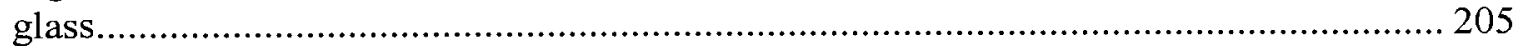

Figure 105: Bulk analysis of glass and Calbuco and Osorno eruptive products. ........... 208

Figure 106: Sketch of Calbuco Magma Storage Zones. ................................................ 209 


\section{Chapter 1. Introduction}

Calbuco Volcano is located in the Central Southern Volcanic Zone (CSVZ) of Southern Chile (Figure 1). Although it is surrounded by numerous active volcanic centers, it is different from these other volcanoes in its eruptive style and eruptive products. Calbuco is an explosive volcano in contrast to the widespread effusive volcanism in this area. Eruptions typically include lahars and pyroclastic flows, in addition to surges (lateral blasts), block and ash flows, and subplinian eruptions. Calbuco is also unusual petrographically compared to other CSVZ composite stratovolcanoes because: 1) hornblende is a phenocryst; 2) andesite is the predominant product rather than basalt; and 3) there are gabbro and granulite xenoliths in the lavas (López-Escobar, et al., 1995). The presence of hydrous minerals in the eruptive products, such as hornblende, and the explosive eruptive history suggest that the Calbuco magma is more water-rich than that at surrounding volcanic centers. The eruptive products of surrounding volcanoes do not have hydrous mineral assemblages. As an example, the nearest neighboring volcano, Osorno, $18 \mathrm{~km}$ to the north, has porphyritic eruptive products (basalt and andesite) that contain phenocrysts of plagioclase and clinopyroxene (LópezEscobar and Parada, 1991).

Previous work based on bulk rock chemistry proposed that Calbuco andesites developed by crustal contamination, fractional crystallization of an assemblage with hornblende, and magma mixing (López-Escobar et al., 1995 and Hickey-Vargas et al., 1995). This project is focused on understanding some of the internal processes at work inside Calbuco on a finer scale by examining the individual mineral phases, particularly plagioclase and hornblende. Compositional zoning of plagioclase is studied in detail to 
determine what, if any, magmatic processes are recorded during the growth of the crystal. Previous work has shown that processes, such as magma mixing, the presence of water in the magma, magmatic temperature fluctuations, and magma chamber convection can be recorded in major element zoning of plagioclase. Studies of plagioclase major and trace element zoning have been conducted at Tatara-San Pedro (Chile; Singer et al., 1995), Thera Volcano (Greece; Stamatelopoulou-Seymour et al., 1990), Medicine Lake Volcano (California; Brophy et al., 1996), Soufrière Hills (Montserrat; Zellmer et al., 2003; Stewart and Fowler, 2001), Mount St. Helens (Washington; Pearce et al., 1987), Iztaccíhuatl Volcano (Mexico; Nixon and Pearce, 1987), Seguam Volcano (Alaska; Singer et al., 1993; Singer and Pearce, 1993), Laacher See (Germany; Ginibre et al., 2004), Parinacota Volcano (Chile; Ginibre et al., 2002b), Mount Pinatubo (Philippines; Hattori and Sato, 1996), and Zigana Granitoid (Turkey; Karsli et al., 2004). Hornblende is studied to try to determine the composition of the mineral assemblage of the breakdown reaction products. The presence of hornblende in arc volcanics is not well understood. Questions as to whether it crystallizes from the magma or whether it forms due to later reactions have been posed by Costa et al. (2002). Little is known about how andesites are actually formed despite the fact that the Earth's crust has an overall andesitic composition. Arguments for andesite formation have included elevated dissolved water contents in the magma (Allen and Boettcher, 1978 and 1983; Moore and Carmichael, 1998; Foden and Green, 1992), crystal fractionation (Grove and Baker, 1984; Moore and Carmichael, 1998; Pichavant et al., 2002; Beard, 1986; Grove et al., 1982; López-Escobar et a1., 1995; Cawthorn and O’Hara, 1976 and references therein), crystallization of hornblende (Allen and Boettcher, 1978 and 1983; Green and Ringwood, 
1967; Cawthorn and O'Hara, 1976; Yagi and Takeshita, 1987; López-Escobar et al., 1995), magnetite crystallization (Cawthorn and O'Hara, 1976 and references therein; Martel et al., 1999), crustal assimilation (Grove et al., 1982; López-Escobar et al., 1995), magma mixing (Grove et al., 1982; López-Escobar et al., 1995), partial melting of subducted oceanic crust (Cawthorn and O'Hara, 1976 and references therein), and direct and partial melting of mantle peridotite (Cawthom and O'Hara, 1976 and references therein). Since Calbuco andesites have a complex mineral assemblage, each mineral phase is also examined to try to determine the relationship between phases. Study of the textures, such as breakdown textures present or phenocryst rims, and compositions of the mineral phases present in the andesite will lead to an understanding of phase stability in the Calbuco magma chamber. This study of andesites and magmatic processes at Calbuco is important to help advance the understanding of andesite genesis worldwide.

Calbuco is an understudied volcano, in comparison with well known volcanic centers such as Mt. Saint Helens or Soufrière Hills, but is actually of great importance locally due to its explosive nature. Calbuco Volcano is surrounded by inhabited towns and villages, such as Ensenada to the northeast, Puerto Varas to the west, and Puerto Montt to the south, and poses a potentially serious threat to these people by endangering their life, home, and livelihood. Proper volcanic hazard mitigation of the threat posed by Calbuco is essential, however a thorough understanding of the internal magmatic processes of Calbuco, which this project will contribute to, is essential to successfully interpret and predict the external behavior of the volcano.

The next several chapters, 2 through 6 include primarily descriptive information, followed by interpretation in chapters 7 and 8 . Chapter 2 contains a description of the 
regional geologic and tectonic information for Southern Chile Calbuco as well as the volcanic history of the volcano and a review of prior geochemical work. Chapter 3 describes the collection of new samples, their preparation, and methods of analysis. Chapter 4 contains a detailed description and comparison of the textures, chemistry and mineral assemblages of the andesite, basaltic andesite, as well as the crystal clusters found in both, and gabbroic xenoliths found in the andesite. Chapter 5 includes a detailed description and comparison of hornblende chemistry and textures in both the andesite and gabbroic xenoliths. This chapter also includes a detailed description of the hornblende breakdown products found, including texture and mineral assemblage. Chapter 6 includes a detailed description of plagioclase crystal populations present in Calbuco andesite and basaltic andesite along with the major, minor, and trace element zoning found. This chapter also details the resorption textures and surfaces found along with plagioclase growth between resorption events and the chemistry of glass trapped within plagioclase crystals. Chapter 7 contains discussion of hornblende crystallization and subsequent breakdown as well as magma chamber processes recorded in plagioclase zoning. This chapter also discusses an overview of magma properties, of both andesite and basaltic andesite, as well as an overview of magmatic processes inside Calbuco. Chapter 8 contains interpretation of hornblende formation and breakdown reaction product, as well as the genesis of cumulate gabbroic xenoliths. This chapter also contains interpretation of the magma chamber processes recorded in plagioclase zoning and the synthesis of Calbuco and the magma storage zone. Chapter 9 is a listing of the references. 


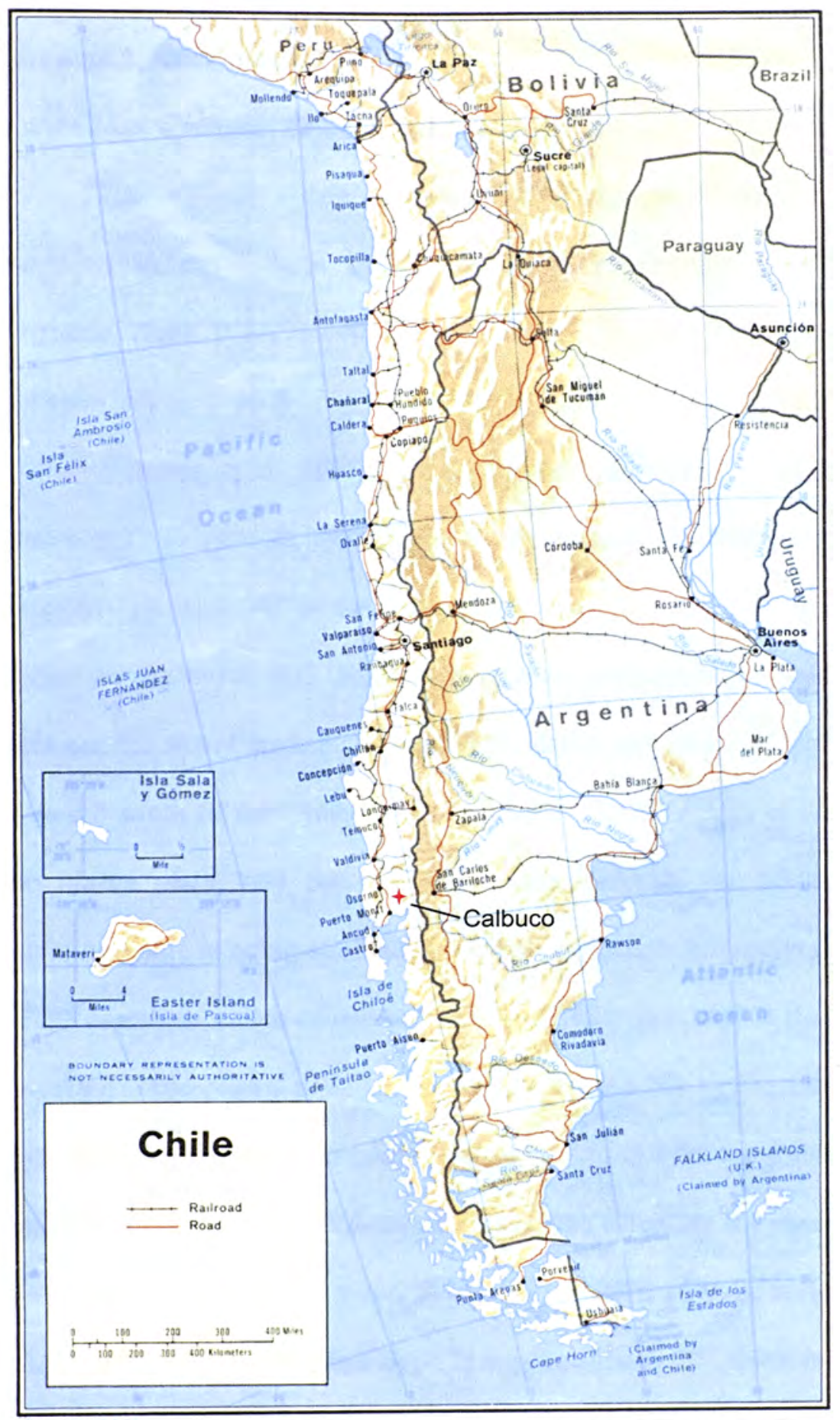

Figure 1: Geographic map of South America showing the location of Calbuco Volcano. Map from: www.reliefweb.int/rw/fullMaps 


\section{Chapter 2. Background}

\subsection{Andean Volcanic Zones - Geology and Tectonics}

The Andean Volcanoes are divided into four separate volcanic segments; the Northern Volcanic Zone (NVZ), between the latitudes of $5^{\circ} \mathrm{N}$ and $2^{\circ} \mathrm{S}$, the Central Volcanic Zone (CVZ), between $14^{\circ}$ and $28^{\circ} \mathrm{S}$, the Southern Volcanic Zone (SVZ), between $33^{\circ}$ and $46^{\circ} \mathrm{S}$, and the Austral Volcanic Zone (AVZ), between $49^{\circ}$ and $55^{\circ} \mathrm{S}$ (López-Escobar, et al., 1995). These regions are defined by geological boundaries on the Nazca plate (Figure 2). Along the Andean Cordillera from north to south, the southern boundary of the NVZ is the Carnegie Ridge. The CVZ is situated between the Nazca Ridge on the north and the Juan Fernandez Ridge on the south. The SVZ is located between the Juan Fernandez Ridge in the north and the Chile Rise in the south. The AVZ is found south of the Chile Rise. Volcanism in the Andes is the result of subduction of the Nazca plate, and the Antarctic plate, beneath the South American plate. The Antarctic plate is being subducted beneath the South American plate in the extreme south of the continent, south of approximately $48^{\circ} \mathrm{S}$ latitude, and is responsible for formation of the AVZ. The Nazca plate is moving toward the NE and is subducting below the South American plate at a rate of approximately $8 \mathrm{~cm} / \mathrm{yr}$ (Lavenu and Cembrano, 1999). The dipangle of subduction varies from north to south affecting the presence of volcanic activity. Between the latitudes of $5^{\circ} \mathrm{N}-2^{\circ} \mathrm{S}(\mathrm{NVZ}), 16-28^{\circ} \mathrm{S}(\mathrm{CVZ})$, and south of $33^{\circ} \mathrm{S}$ (SVZ and AVZ), where the subduction angle is approximately $30^{\circ}$, there is active volcanism. Areas where the subduction dip-angle is shallow, approximately $5-10^{\circ}$, are lacking in volcanism, between the latitudes of $2-15^{\circ} \mathrm{S}$ and $27-33^{\circ} \mathrm{S}$ (Thorpe, 1984). According to 
Hickey et al. (1984), in the SVZ the major volcanic chain is located approximately 300 $\mathrm{km}$ from the Peru-Chile Trench. The depth to the Benioff zone varies within the four regions of the Andes. Beneath the NVZ and CVZ it is at a depth of approximately 140 $\mathrm{km}$, and beneath the SVZ and AVZ it is shallower, at a depth of approximately 90-120 $\mathrm{km}$ (Thorpe, 1984). Within the SVZ, between $38^{\circ}-46^{\circ} \mathrm{S}$, the subduction angle of the Nazca plate is approximately $26^{\circ}$ and the age of the subducted crust decreases southward from approximately $25 \mathrm{Ma}\left(\right.$ at $38^{\circ} \mathrm{S}$ ) to approximately $0 \mathrm{Ma}$ where the Chile Ridge is currently being subducted (at $46^{\circ} \mathrm{S}$ ) (Cembrano et al., 2000).

Variations in the age and crustal thickness beneath the NVZ, CVZ, SVZ, and AVZ are detailed by Thorpe (1984). The crust beneath the NVZ is Paleozoic-Mesozoic in age and approximately $40-50 \mathrm{~km}$ thick. Below the CVZ the crust thickens to approximately $70 \mathrm{~km}$, dating $2000 \mathrm{Ma}$; this thick segment of crust may be part of the Brazilian Shield. The crust underneath both the SVZ and AVZ is also PaleozoicMesozoic in age, however in these zones the crust decreases to approximately $35 \mathrm{~km}$ thick. Volcanic products in the four different volcanic zones, NVZ, CVZ, SVZ, and AVZ, have distinct petrologic characteristics. The NVZ lavas are predominantly basaltic andesite and andesite, the CVZ lavas range from basaltic andesite to dacite, while the SVZ and AVZ lavas are typically basalt and basaltic andesite in composition (Thorpe, 1984).

\section{1 a The Southern Volcanic Zone}

The SVZ is subsequently divided into four regions, the northern SVZ (NSVZ; $33^{\circ}-34^{\circ} 30^{\prime} \mathrm{S}$ ), the transitional SVZ (TSVZ; $\left.34^{\circ} 30^{\prime}-37^{\circ} \mathrm{S}\right)$, the central SVZ (CSVZ; $37^{\circ}-$ $\left.42^{\circ} \mathrm{S}\right)$, and the southern SVZ (SSVZ; $\left.42^{\circ}-46^{\circ} \mathrm{S}\right)$ on the basis of petrological, 
geochemical, and tectonic considerations (Tormey et al., 1991). One factor which may be affecting the type of lava produced in each of the subdivisions of the SVZ is the variation in the thickness of the continental crust beneath these four regions. This variation in thickness is detailed by López-Escobar, et al. (1995). The continental crust is thickest beneath the NSVZ, 55-60 km, and the lavas produced are predominantly andesites and dacites. Beneath the TSVZ the thickness of the continental crust decreases southward from $55 \mathrm{~km}$ to $35 \mathrm{~km}$ and the prevailing lava types are andesite and dacite with an increasing abundance of basalt. The thickness of the crust beneath both the CSVZ and SSVZ was reported to be $30 \mathrm{~km}$ or less and the lavas produced are primarily basalt with the occurrence of minor andesite, dacite, and rhyolite. Calbuco Volcano is located at $41^{\circ} 20^{\prime} \mathrm{S}$ within the CSVZ.

\subsection{Regional Geology of Southern Chile}

The plate boundary off the Pacific coast of Southern Chile is an active margin caused by the subduction of the Nazca Plate beneath the South American plate. Along an east-west transect across Southern Chile (Figure 3) there are three main zones: a fore arc zone, the active volcanic zone, and a foreland zone (Lavenu and Cembrano, 1999). The fore arc zone is made up of the Coastal Range and the Central Depression. According to Lavenu and Cembrano (1999), the Coastal Range is made up of several independent blocks displaced from each other, and therefore is not a coherent coastal sliver. The border between the Coastal Range and the Central Depression consists of a series of N-S striking fault systems. The Central Depression is a half-graben over $1000 \mathrm{~km}$ long, 75 $\mathrm{km}$ wide, and trends N-S. The northern and southern limits of the Central Depression are the geographic limits of the Southern Volcanic Zone, and the eastern border of the 
Central Depression is straight and parallel to the Main Cordillera, but is not a tectonically active feature (Lavenu and Cembrano, 1999). The Main Cordillera is located in the active volcanic zone and is divided by the Liquiñe-Ofqui Fault Zone (LOFZ) (Figure 4). The (LOFZ), located within the SVZ, is one of the largest strike-slip faults associated with active subduction (López-Escobar et al., 1995). The LOFZ is an intra-arc strike-slip fault (Cembrano et al,. 2000) characterized by two main NNE trending straight lineaments which are offset from each other and connected by a series of en échelon faults. These two straight lineaments run from $39^{\circ}$ to $44^{\circ} \mathrm{S}$ and from $44^{\circ}$ to $47^{\circ} \mathrm{S}$ with a right step at $44^{\circ} \mathrm{S}$ (Cembrano et al., 1996 and 2000). In conjunction with the LOFZ, there are small eruptive centers (SEC) to the east of the main volcanic belt, which run roughly parallel to the LOFZ. These SEC consist mainly of maars and scoria cones either with or without lava flows. Lava flows ranging from basalt to basaltic andesite in composition have been found (López-Escobar et al., 1995). There is an elevation difference of 600$800 \mathrm{~m}$ between the basement east and west of the LOFZ. On the east side of the LOFZ, beneath the Main Cordillera, the basement appears to be uplifted blocks (Lavenu and Cembrano, 1999). The foreland zone is predominantly located in Argentina.

\section{2a Basement Lithology}

The oldest basement rocks exposed within the area near Calbuco are Jurassic to Cretaceous in age, and mid to late Paleozoic basement is exposed along the coast and eastern Andes (Hickey et al., 1984). The North Patagonian batholith, which forms the majority of the southern Chilean Andes, consists of a Late Jurassic-Early Cretaceous belt on the west, a narrow Miocene-Pliocene belt in the center, and a mid-Cretaceous belt on the east (Cembrano et al., 2000). Cembrano et al. (2000) describe the Patagonian 
batholith as heterogeneously deformed granodioritic to tonalitic plutonic rocks and minor undeformed granite and leucogranite, all of which intrude low- to medium-grade metamorphic rocks. Metamorphic rocks of the Sotomó Chaiquenes Metamorphic Complex are found within the active volcani belt approximately $10 \mathrm{~km}$ south of Calbuco (Figure 7). Hickey-Vargas et al. (1995) indicated that these intruded metamorphic rocks closely resemble Paleozoic sequences found in the Coastal Metamorphic Complex (Coastal Range from Lavenu and Cembrano, 1999), which is a continuous belt from $33^{\circ}$ to $55^{\circ} \mathrm{S}$ and is made up of metabasaltic and metasedimentary rocks.

\subsection{Calbuco Volcano}

Calbuco Volcano (Figure 5) is a Late Pleistocene to Holocene active composite stratovolcano located at $41^{\circ} 20^{\prime} \mathrm{S}$ in the CSVZ (Figure 2). Calbuco is $1,800 \mathrm{~m}$ in height, 2,003 $\mathrm{m}$ above sea level, and its base covers approximately $150 \mathrm{~km}^{2}$ (Moreno et al., 2004). According to Hickey-Vargas et al. (1995), López-Escobar et al. (1995), and Moreno et al. (2004), Calbuco Volcano is immediately underlain by over $550 \mathrm{~m}$ of Early Pleistocene volcanic sequences, the Hueñuhueñu and the Reloncaví Strata, which consist of volcaniclastic material and basaltic lavas (Figure 6). These volcanic sequences overlie Miocene (16 to $10 \mathrm{Ma}$ ) granites, diorites, and gabbros from the Patagonian batholith (Figure 7) (Hickey-Vargas et al., 1995; López-Escobar et al., 1995; Moreno et al., 2004). The basement beneath the area of the LOFZ consists of the same volcanic sequence, the Reloncaví Strata, which underlies Calbuco, and the SEC also overlies Miocene rocks from the Patagonian batholith (López-Escobar et al., 1995). Calbuco sits on top of an uplifted block, which is continuing to be uplift at a rapid rate of $0.9 \mathrm{~mm} / \mathrm{yr}$ (Moreno et al., 2004). 


\section{3a Volcanic History}

Calbuco is generally violently eruptive with eleven documented eruptions since the $18^{\text {th }}$ century, the most explosive eruption in 1893 (Appendix A). Typical eruptions will generate pyroclastic flows, hot lahars, subplinian eruptions, and blocky lava flows. In the last $\sim 90,000$ years there have been three caldera collapses. Calbuco's eruptive products (Figure 8), which cover a total area of approximately $1,500 \mathrm{~km}^{2}$, are divided into four units, Calbuco 1-4 (Moreno et al., 2004; Moreno, personal communication), which are separated in time by large scale caldera collapses. The first unit, Calbuco 1, predates the last glaciation and lasted until approximately 90,000 years ago. Calbuco 1 was significantly eroded by the glaciation, and the intraglacial unit, Calbuco 2, formed above the roots of the eroded volcano. Calbuco 2 lasted until approximately 13,900 years ago, collapsing toward the NNE. Dome growth during the Calbuco 3 period produced a larger cone than during the Calbuco 2 period. The collapse of Calbuco unit 3 was before the beginning of recorded history and also toward the NNE. Calbuco 4 is the volcanic unit within recorded history. Since its last major eruption in 1961, there has been a small ash eruption (1972), sporadic fumaroles on the main crater (1995-1999) and ongoing new cone growth, currently at a height of approximately $50 \mathrm{~m}$ (Moreno et al., 2004; Moreno, personal communication)

\section{3b Prior Geochemical Work}

Geographically, the distribution of basalt in the Andes seems to be concentrated south of $36^{\circ} \mathrm{S}$, and andesite and rhyolite are typically found north of $36^{\circ} \mathrm{S}$ due to the thickness of the crust (Hickey et al., 1984). Calbuco is located south of $36^{\circ} \mathrm{S}$; its lavas, however, are porphyritic andesites and rare basaltic andesites. The andesites contain 
crustal xenoliths and the mineral assemblage includes plagioclase, orthopyroxene, magnetite, and rare clinopyroxene, olivine, and hornblende. The crustal xenoliths are both pyroxene granulites and hornblende gabbronorites (Hickey-Vargas et al., 1995). The surrounding Small Eruptive Centers (SEC) and nearby stratovolcanoes, including Osorno, are predominantly basaltic. Osorno also has a small amount of dacite (LópezEscobar et al., 1995). López-Escobar et al. (1995) and Hickey-Vargas et al. (1995) studied the bulk rock elemental and isotope geochemistry of Calbuco andesite and xenoliths. They concluded: 1) there is isotopic evidence of crustal contamination of the magma (Figure 9); 2) hornblende crystallized from the magma and underwent decompression melting during ascent to the surface; 3) the isotopic and trace element evidence for magma mixing with a more silicic magma is lacking; and 4) the gabbro xenoliths are actually cognate cumulates of the crystallizing assemblage entrained in the magma rather than true xenoliths. López-Escobar et al. (1995) and Hickey-Vargas et al. (1995) concluded that subtraction of about $30 \%$ of the gabbroic assemblage from the parent basalt could produce the andesitic composition of Calbuco (Figure 10). The crustal xenoliths, both the granulites and hornblende gabbronorites, were determined not to have the appropriate geochemical characteristics to be the crustal contaminants of Calbuco andesites (Figure 9) (Hickey-Vargas et al., 1995). 


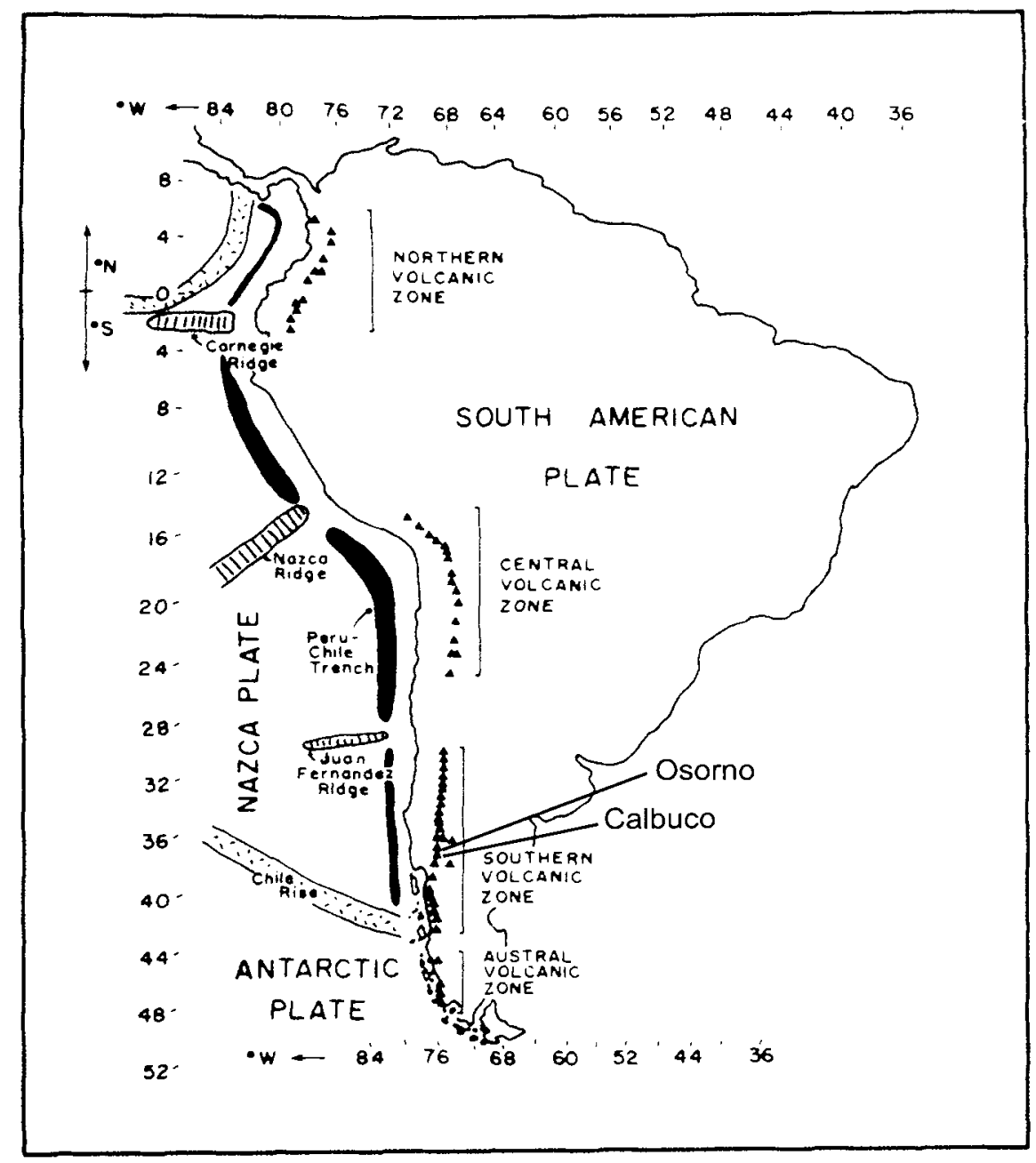

Figure 2: Map of South America.

Map of South America showing the four Andean volcanic zones and the location of the features on the Nazca plate which are responsible for the volcanic zones. Osorno and Calbuco are also shown. Figure after López-Escobar (1984). 


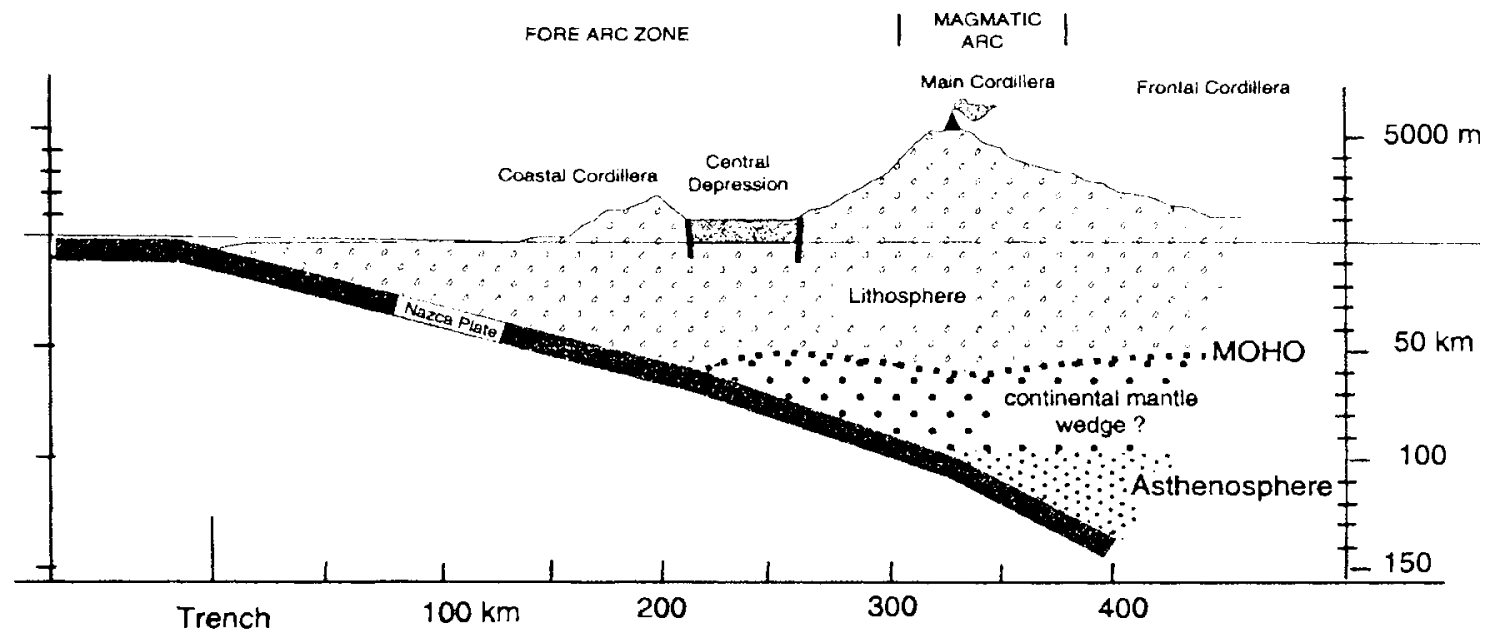

Figure 3: East-West transect across Southern Chile.

Transect across Southern Chile from east to west showing the fore arc zone, the active volcanic zone, and the beginning of the foreland zone. The fore arc zone consists of the Coastal Range (Coastal Cordillera) and Central Depression. The active volcanic zone is the Main Cordillera and is divided by the LOFZ. The foreland zone is to the east of the active volcanic zone and is mostly in Argentina. Diagram from Lavenu and Cembrano (1999). 


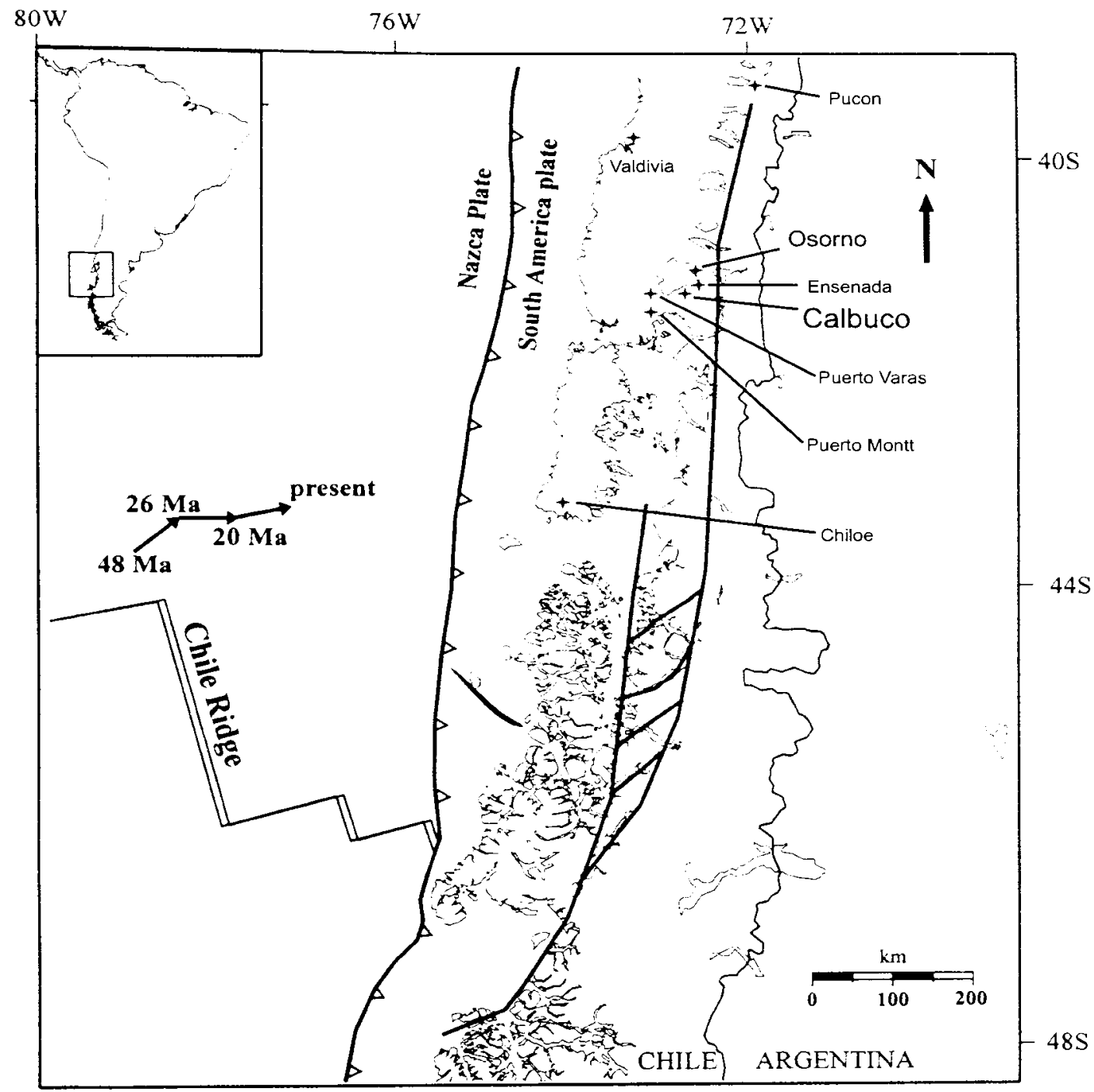

Figure 4: Map of the Southern Volcanic Zone (SVZ).

Southern Chile map with an inset showing the location of the SVZ relative to South America, and the trace of the Liquiñe-Ofqui Fault Zone (LOFZ) running from north to south. The fault has a right step at $44 \mathrm{~S}$ and the two segments are connected by a series of en echelon faults. The locations of Calbuco and Osorno are show in addition to nearby towns and cities. The direction of the motion of the Nazca plate over the last $48 \mathrm{Ma}$ is indicated. Figure after Cembrano et al. (2000). 


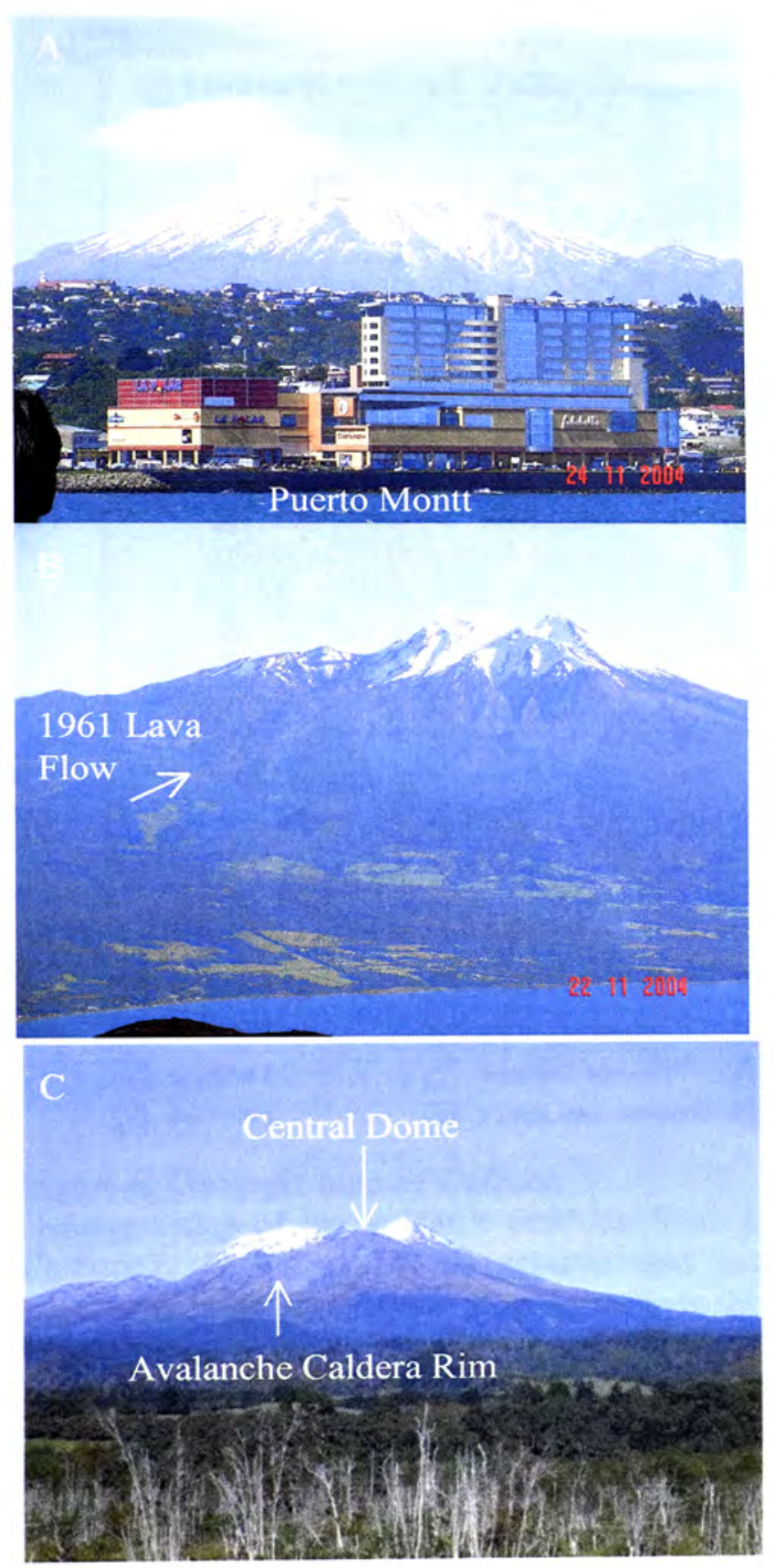

Figure 5: Photographs of Calbuco Volcano.

$\mathrm{A}$ is the view from the south of the volcano, taken from Puerto Montt, showing the proximity of the volcano to a major city. B is from Osorno volcano and the view is from the north. The lava flow from the 1961 eruption is indicated. C is also taken from the north. The avalanche caldera rim from the caldera collapse at ending Calbuco unit 2 and current central dome are indicated. Photograph $\mathrm{C}$ by Hugo Moreno. 


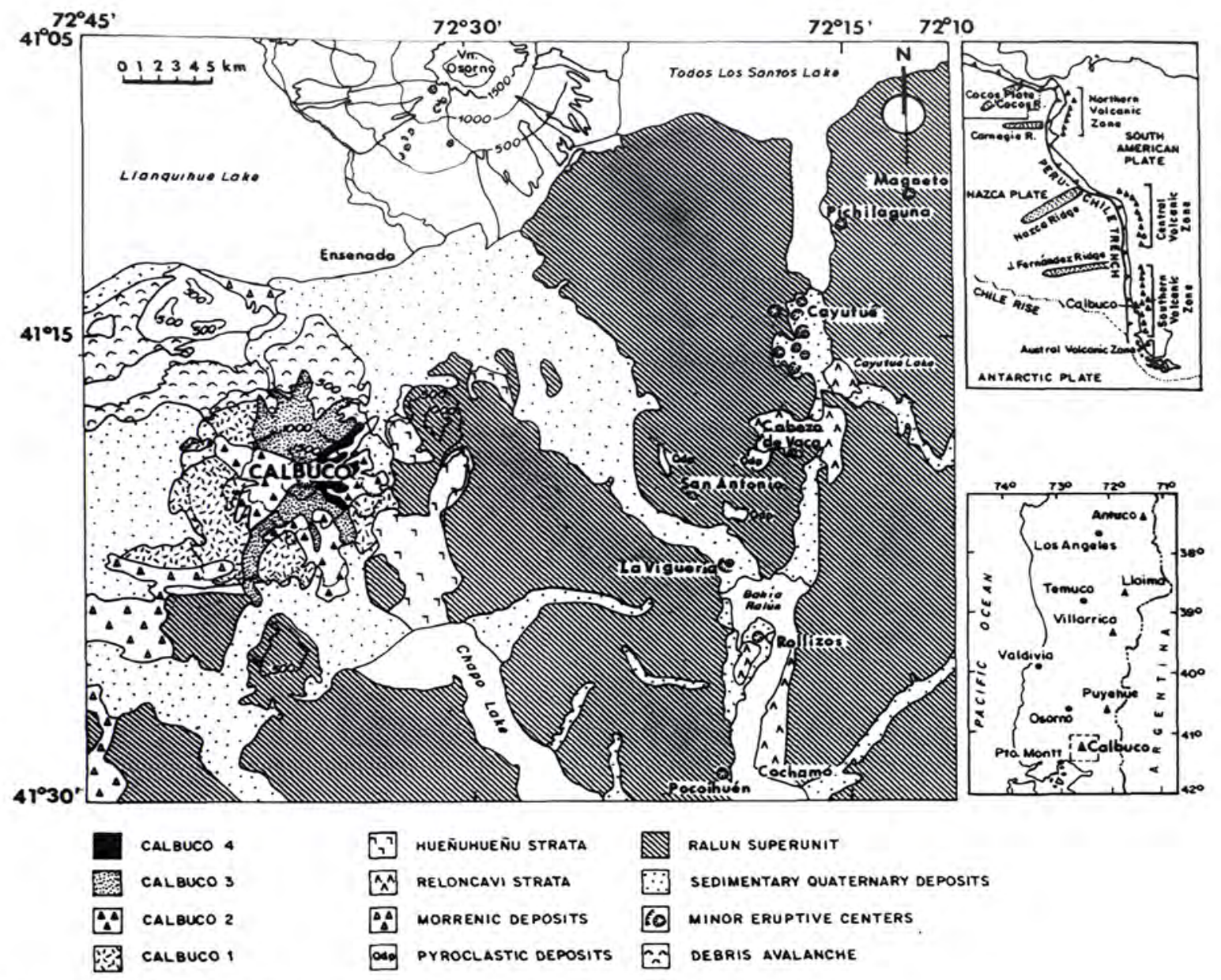

Figure 6: Geologic map of Calbuco.

Geologic map of the volcanic products from Calbuco showing the four volcanic units, Calbuco1, 2, 3, and 4, pyroclastic and debris avalanche deposits, and basement sequences. The basement sequences include the Reloncaví Strata and Hueñuhueñu Strata which are early Pleistocene volcanic sequences. The Reloncaví Strata consists of basaltic lavas, volcanic breccia, and lapilli. The Hueñuhueñu Strata consists of volcaniclastic material and basalt. The Ralún Superunit consists of a Miocene plutonic belt of the Northern Patagonian Batholith (López-Escobar et al., 1992). Map and description of basement units from López-Escobar et al. (1995). 


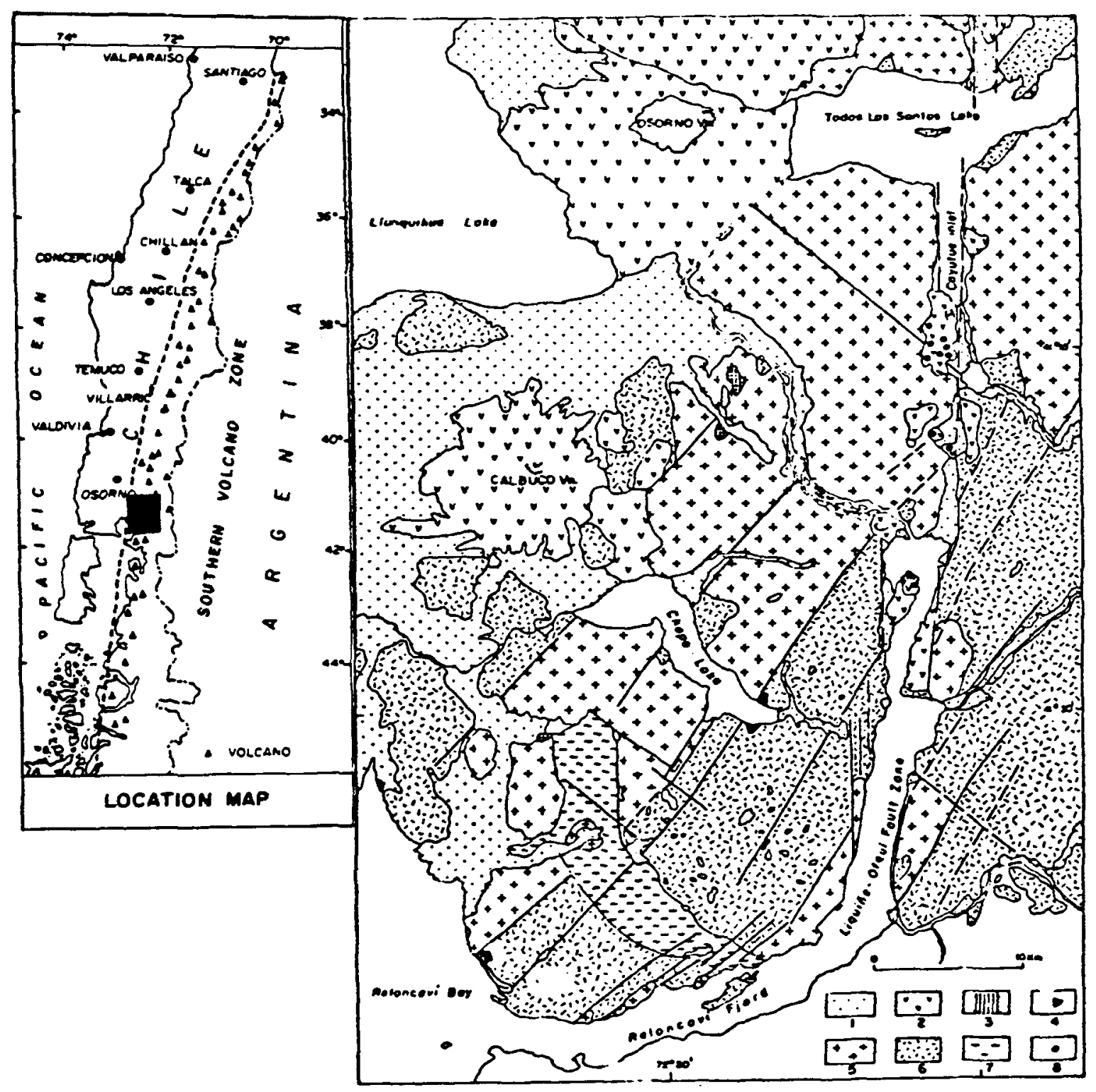

Figure 7: Geologic map of the basement rock near Calbuco.

Geologic map of the basement rock in the area of Calbuco with an inset map of Chile showing the location of the Southern Volcanic Zone and the area mapped. Symbols in the key are: 1-quaternary sediments; 2-modern lava and pyroclastic flows; 3-Peninsula Rollizos gabbro (Miocene); 4-Lago Chapo unit (leucogranites; Miocene); 5-Cayutue unit (gabbro, diorite, quartz diorite; Miocene); 6-Reloncaví unit (tonalites, granodiorites; Miocene); 7-Sotomó-Chaiquenes high grade metamorphic complex (schist and gneiss; Paleozoic); 8-deposits from small eruptive centers. Diagram from Parada et al. (1987). 


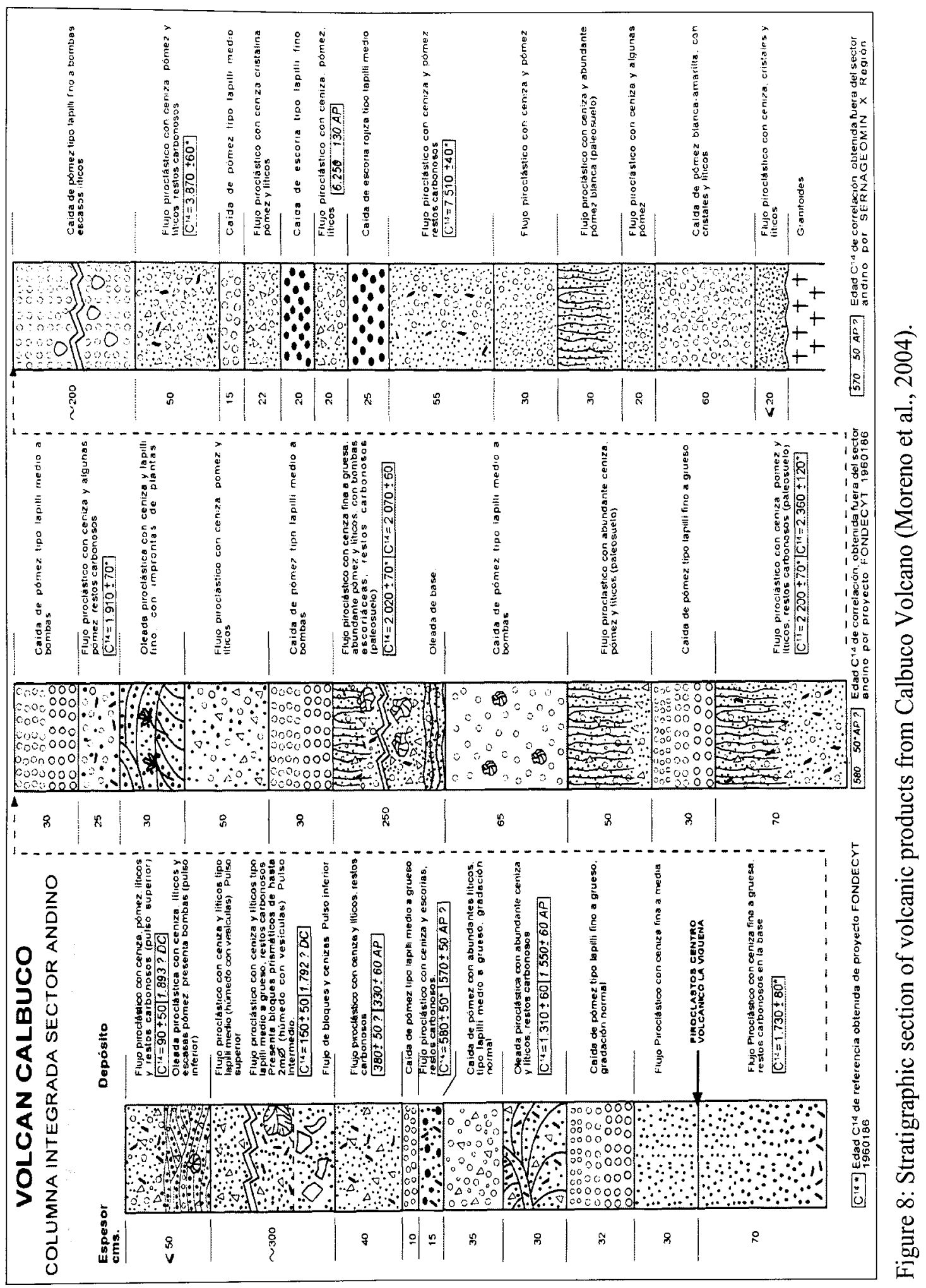




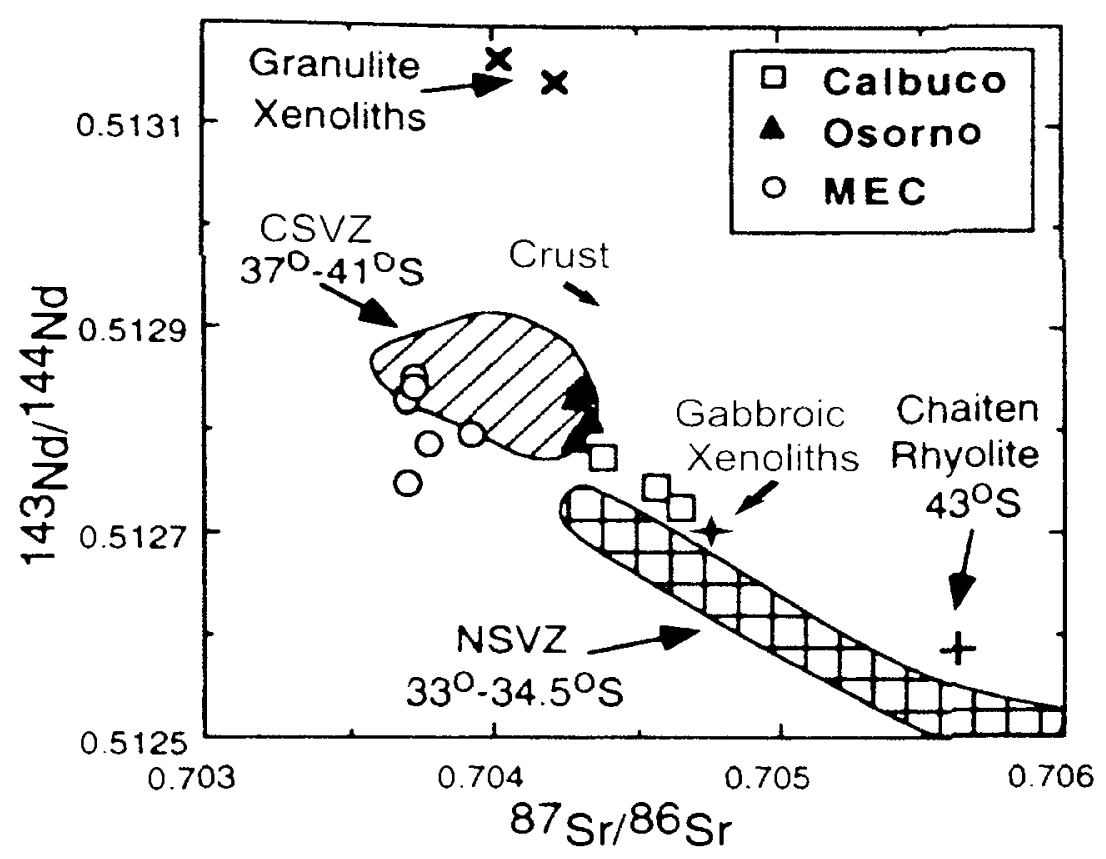

Figure 9: Sr versus Nd isotope plot for Calbuco bulk rock analysis.

Plot showing Sr versus Nd isotopes for Calbuco, Osorno, the Small Eruptive Centers, granulite and gabbronorite xenoliths, and the CSVZ and NSVZ regions. An increasingly negative correlation between $\mathrm{Sr}$ and $\mathrm{Nd}$ in magma is indicative of increasing crustal signature, or crustal contamination. Calbuco plots away from Osorno and the rest of the CSVZ in the direction of the crust. This plot also shows that the granulite xenoliths do not have the isotopic signature to be crustal contaminants of Calbuco. Figure after López-Escobar et al. (1995). 


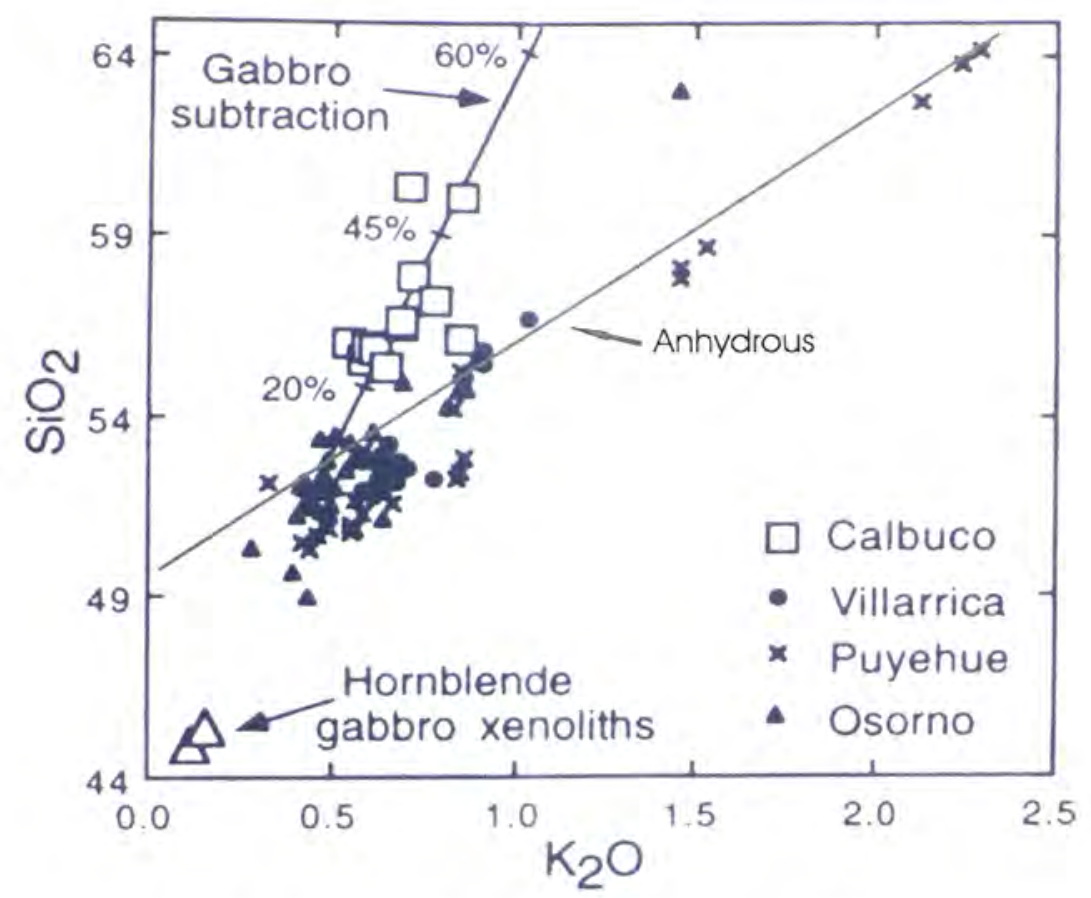

Figure 10: $\mathrm{SiO}_{2}$ versus $\mathrm{K}_{2} \mathrm{O}$ plot of gabbroic xenoliths.

$\mathrm{SiO}_{2}$ versus $\mathrm{K}_{2} \mathrm{O}$ plot showing cumulate xenoliths (i.e. hornblende gabbros) in relation to Osorno and Calbuco Volcanoes. Gabbro subtraction line was calculated by LópezEscobar et al. (1995) and indicates that Calbuco lavas do not plot along an anhydrous trend and can be reproduced by subtracting approximately $30 \%$ of the cumulate gabbro assemblage from Osorno lavas. Figure after López-Escobar et al. (1995). 


\section{Chapter 3. Methods}

\subsection{Sample Collection of New Samples}

A small number of new samples from Calbuco unit 2 were collected from Calbuco Volcano in November of 2004. These samples were of lava flows, pyroclastic and surge deposits, block and ash flows, and debris avalanche flow in contrast to all previous samples which were only of lava flows. Figure 11, which is from a field trip guide prepared by Moreno et al., 2004, shows the location of collection of each of these and is referred to in the following explanation. On the west side of the volcano, samples were collected at field trip stops C-4 2.1, 2.4, and 2.5. One sample (C-4 2.1A) of potentially "juvenile material" (Moreno, personal communication) was collected at a road cut labeled 2.1 on the map, which was a hummock, or debris avalanche deposit. Location 2.4 on the map was a pyroclastic/surge deposit and a block and ash flow deposit which had been used as a quarry. Three samples of lava blocks and scoria were collected at this location (C-4 2.4A, C-4 2.4B, and C-4 2.4C). The last sample collected on the west side of Calbuco was scoria (C-4 2.5 A) at location 2.5, which was a block and ash flow and surge flow deposit. On the east side of the volcano two pumice samples were collected (C-4 3.3A upper and C-4 3.3B lower). These samples were collected at location 3.3 which was a fallout deposit. This particular deposit was very weathered.

\subsection{Sample Preparation}

Both recently and formerly collected samples were selected and cut for thin section preparation and for whole rock analysis. The polished thin sections were made by National Petrographics and were suitable for use with the petrographic microscope but 
were not adequately polished for microprobe analysis. I attempted to polish approximately four of them but I was unsuccessful.

Thick rock chips, cut to the approximate size of $1 \times 2$ inches and between $1 / 4$ and $1 / 2$ inch thick, were prepared for laser ablation ICP-MS analysis of plagioclase phenocrysts. These were also polished to be used on the microprobe, by Maria Pages, an undergraduate Geosciences major. These samples were first to be put into the microprobe for major element analysis of the plagioclase zoning by running a transect from core to rim, and then a second transect, which could be run parallel to the microprobe transect, was to be run for trace elements using laser ablation. This method would ensure that the two transects were sampling the same material. After applying this method in my research, I would not recommend this method for future use. Due to the thickness of these samples, analysis with the petrographic microscope was not possible and textural analysis was limited to the use of back-scattered imaging. I would recommend samples being made into thick sections, rather than thin sections, which are thick enough for laser ablation, but still thin enough for use on the petrographic microscope.

Samples selected for whole rock analysis were crushed, powdered, and digested and prepared for major and trace element analysis by Judene Tulloch and Shaunia Stokes, undergraduate interns with the GeoSCOPE program. Whole rock analysis was done for major and trace elements using JY 70 Type III Inductively Coupled Plasma Emission Spectrophotometry (ICP-ES) at Florida International University. Major element analysis was completed by Donna Williams, an undergraduate Geoscience major, and I completed the trace element analysis at a later date. Whole rock analysis was done of the following 
samples: Calbuco-1, C-4 2.1A, C-4 2.4A, C-4 2.4B, C-4 2.4C, C-4 2.5A, C-4 3.3A upper, and C-4 3.3B lower (Table 1).

\subsection{Petrographic Microscope}

An Olympus BH-2 petrographic microscope with a Nikon COOLPIX 5700 digital camera was used for optical and textural analysis and for acquiring photomicrographs. Optical and textural analysis was done on both lava and cumulate xenolith samples using newly prepared thin sections as well as thin sections previously prepared during research by Hickey-Vargas et al. (1995) and Abdollahi (1990).

\subsection{Electron Microprobe}

Electron microprobe analysis of mineral phases in lava and cumulate xenolith samples was done and the Florida Center for Analytical Electron Microscopy (FCAEM) at Florida International University using a JEOL 8900R Electron Microprobe (EPMA) with Back-Scattered Electron Imaging (BSE). Mineral phases analyzed included plagioclase, orthopyroxene, clinopyroxene, magnetite, ilmenite, hornblende, phlogopite, apatite, and olivine. Major element analysis was done with a 30 second count time, 10 second background count time, using $15 \mathrm{kv}$ and a 20 na current and trace element analysis was done with a 240 second count time, 80 second background count time. Major elements analyzed included the following: for plagioclase- $\mathrm{Si}, \mathrm{Al}, \mathrm{Fe}, \mathrm{Mg}, \mathrm{Ca}, \mathrm{Na}$, and $\mathrm{K}$; for orthopyroxene, clinopyroxene, and olivine- $\mathrm{Si}, \mathrm{Ti}, \mathrm{Al}, \mathrm{Cr}, \mathrm{Fe}, \mathrm{Mn}, \mathrm{Ni}, \mathrm{Mg}, \mathrm{Ca}, \mathrm{Na}$, and $\mathrm{K}$; for hornblende- $\mathrm{Si}, \mathrm{Ti}, \mathrm{Al}, \mathrm{Cr}, \mathrm{Fe}, \mathrm{Mn}, \mathrm{Mg}, \mathrm{Ca}, \mathrm{Na}, \mathrm{K}, \mathrm{F}$, and $\mathrm{Cl}$; for magnetite and ilmenite- Si, Ti, Al, Cr, Fe, Mn, Ni, Mg, and S; for phlogopite- Si, Ti, Al, Cr, Fe, Mn, $\mathrm{Mg}, \mathrm{Ca}, \mathrm{Na}, \mathrm{K}, \mathrm{F}, \mathrm{Cl}$, and $\mathrm{Ba}$; for apatite- $\mathrm{Si}, \mathrm{Fe}, \mathrm{Ca}, \mathrm{Ce}, \mathrm{Na}, \mathrm{P}, \mathrm{S}, \mathrm{Mn}, \mathrm{Sr}, \mathrm{F}$, and $\mathrm{Cl}$. Trace elements were only analyzed for plagioclase and included Fe, $\mathrm{Ti}, \mathrm{Mg}$, and $\mathrm{Sr}$. 
Minerals were analyzed on both thin sections and thick rock chips, however with the sample holders available at FCAEM it was difficult to position the rock chips so they were perfectly flat on top and I would not recommend this procedure in the future. Volcanic glass analysis was done using a 10 diameter defocused beam at a 30 second count time and 10 second background count time. Glass was analyzed for $\mathrm{Si}, \mathrm{Ti}, \mathrm{Al}, \mathrm{Fe}$, $\mathrm{Mn}, \mathrm{Mg}, \mathrm{Ca}, \mathrm{Na}, \mathrm{K}$, and P. BSE images were collected of all samples analyzed.

\subsection{Laser Ablation}

Laser ablation analysis was done at Florida International University in the Chemistry Department using a Perkin Elmer Sciex, ELAN DRC II, UP-213 Laser Ablation Inductively Coupled Mass Spectrometer (LA-ICP-MS) with the help of Tatiana Trejos. Samples analyzed were the thick cut rock chips. The initial aim of using laser ablation was to analyze trace elements within individual zones within compositionally zoned plagioclase. The smallest spot size that the laser could be taken down to was 8 microns which caused two problems. First, the compositional zones in the plagioclase were smaller than 8 microns, so data acquisition on individual zones was impossible, and second, with a spot size that small the laser could not return quantitative data. Results of these tests are given in appendix A. The thickness and shape of these rock chips also caused difficulty with the laser ablation analysis. Sample holders for the laser ablation unit hold round samples, and the rock chips were rectangular. Because of this, the laminar air flow that introduces the particles into the mass spectrometer was interrupted and the analysis could not be done without cutting the samples to $5 \mathrm{~mm}$ or less in thickness. Once it was determined that plagioclase zoning could not be analyzed, homogenous cores of plagioclase megacrysts were supposed to be analyzed for trace 
elements. A spot size of 80 microns was to be used and three spots were to be analyzed in the core for $\mathrm{Sr}, \mathrm{Ba}, \mathrm{Ti}, \mathrm{Mg}, \mathrm{B}, \mathrm{Cs}, \mathrm{Rb}, \mathrm{P}, \mathrm{K}$, and $\mathrm{Cr}$. Fe was also to be analyzed with three separate spots, for a total of 6 spots analyzed. This was not possible due to mechanical problems with the instrument. Data reduction of the initial tests was done using the Glitter software package in the Chemistry Department. 




Figure 11: Map of sample collection sites from IAVCEI 2004 field trip guide.

Map from IAVCEI 2004 field trip guide showing Calbuco Volcano and Osorno Volcano. Numbers indicate field trip stops. Samples were collected at stops 2.1, 2.4, 2.5, and 3.3. See text for details of samples collected at each stop. Figure from Moreno et al., 2004. 


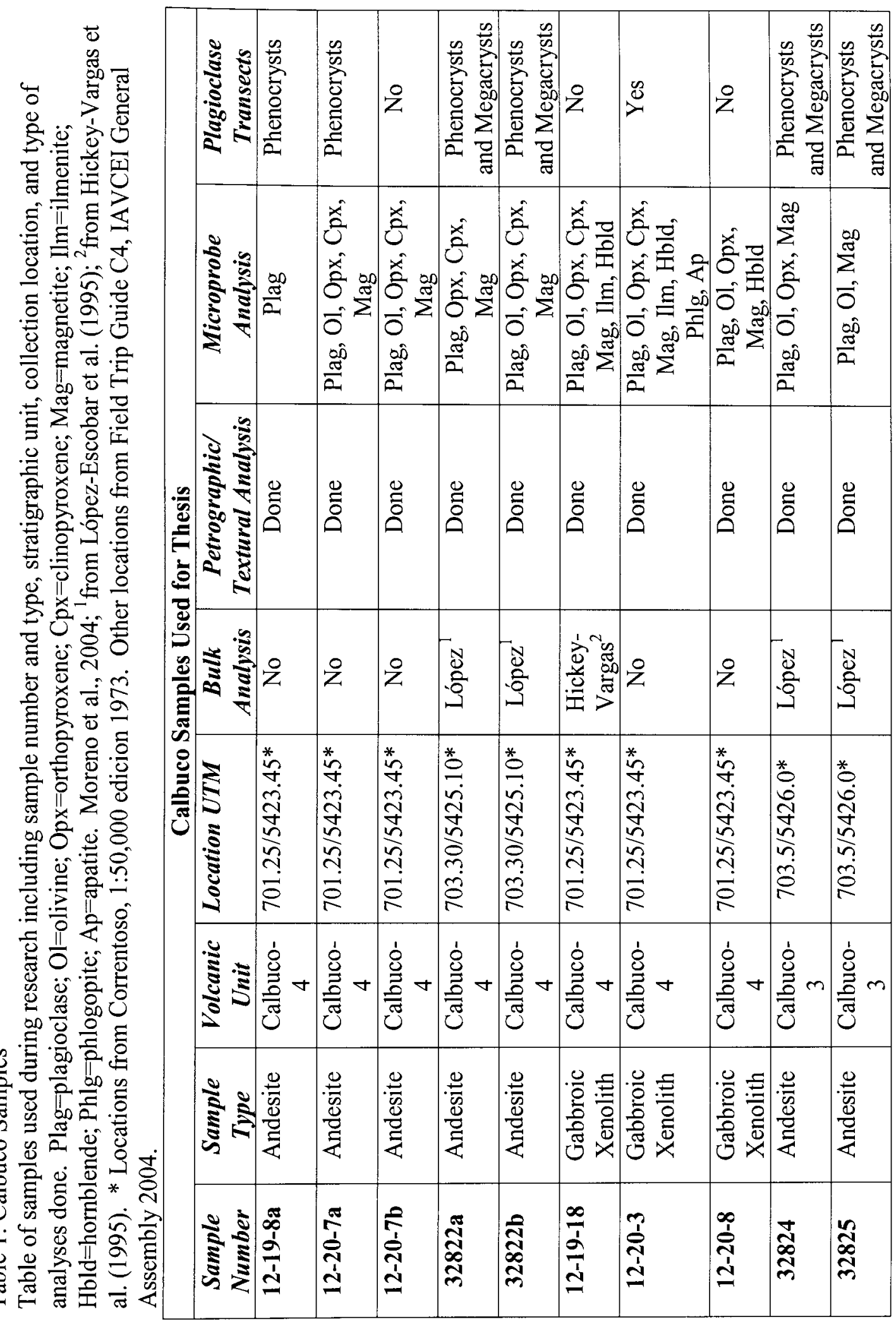




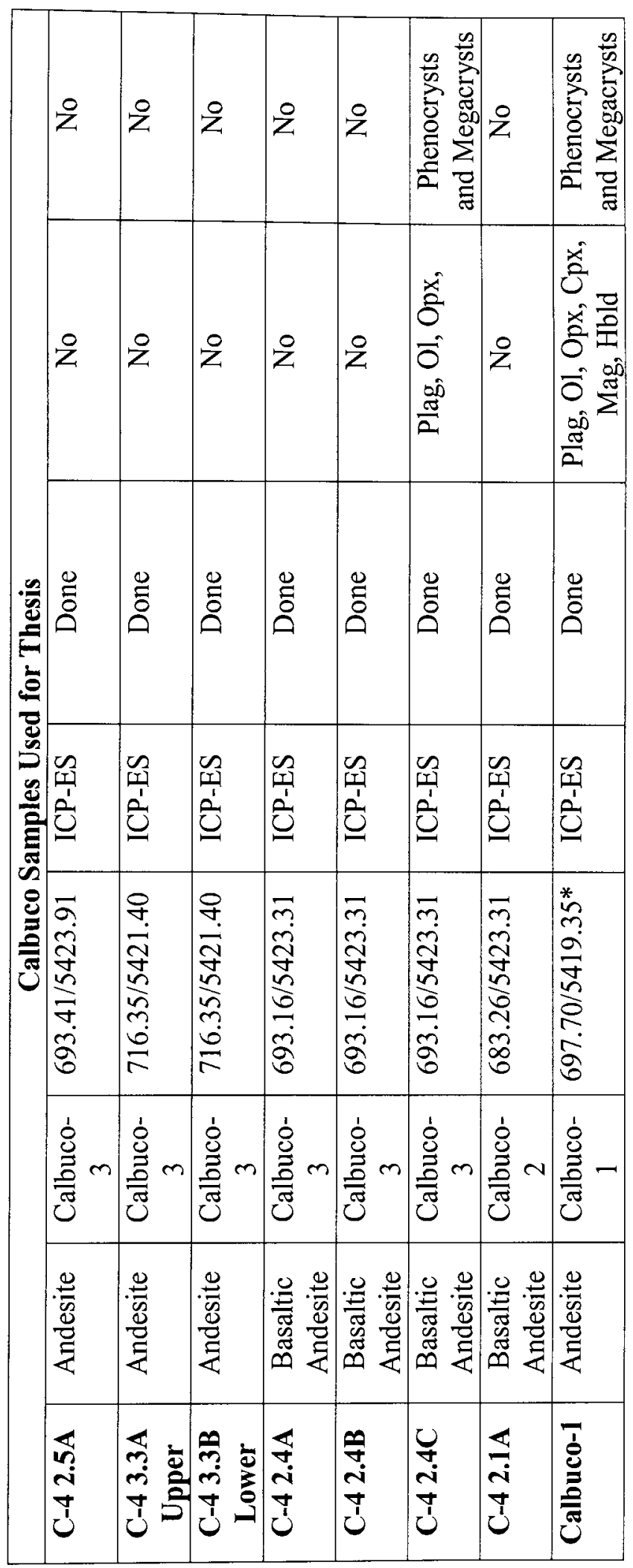




\section{Chapter 4. Chemistry and Petrography of Eruptive Products}

\subsection{Introduction}

Eruptive products from Calbuco, including basaltic andesite, andesite, crystal clusters and gabbroic xenoliths in the andesite, and the individual mineral phases contained in each rock type, have been analyzed chemically. Andesite and basaltic andesite samples have been analyzed for whole rock chemistry by ICP-ES. Volcanic glass and individual mineral phases, plagioclase, clinopyroxene, orthopyroxene, olivine, hornblende, and magnetite, in the basaltic andesite, andesite, crystal clusters, and gabbroic xenoliths have been analyzed for major, minor, and trace element content by electron microprobe. This chapter contains the details of these chemical analyses, along with textural descriptions of the mineral phases present in each eruptive product, together with comparisons of mineral and glass chemistry, and rock and mineral textures in different eruptive products.

\subsection{Whole Rock Chemistry of Newly Collected Samples and Samples Analyzed}

Table 2 gives ICP-ES analysis of the newly collected pyroclastic, surge, fallout, and debris flow deposits. Compositional ranges of these products are from basaltic andesite to dacite. The surge deposit (scoria; $55 \% \mathrm{SiO}_{2}$ ) and fallout deposit (pumice; 58$61 \% \mathrm{SiO}_{2}$ ) samples both fall into the andesitic range with dacite at the higher end of the pumice compositions. The pyroclastic (scoria; 53-54\% $\mathrm{SiO}_{2}$ ) and debris flow (juvenile material; $53 \% \mathrm{SiO}_{2}$ ) deposits are both basaltic andesite. Major element plots (Figure 12) of these newly collected samples and published data (López-Escobar et al., 1995) show that $\mathrm{MgO}, \mathrm{Fe}_{2} \mathrm{O}_{3}, \mathrm{Al}_{2} \mathrm{O}_{3}$, and $\mathrm{CaO}$ are negatively correlated with $\mathrm{SiO}_{2}$ at Calbuco. This is also true for basalts, basaltic andesites, and dacites from Osorno, and Osorno basalts have 
higher concentrations of these oxides than Calbuco. In contrast, $\mathrm{Na}_{2} \mathrm{O}, \mathrm{K}_{2} \mathrm{O}$, and $\mathrm{P}_{2} \mathrm{O}_{5}$ are all positively correlated with $\mathrm{SiO}_{2}$ at both Osorno and Calbuco, and the concentration of these oxides at Osorno is lower than at Calbuco. However $\mathrm{TiO}_{2}$ is positively correlated with $\mathrm{SiO}_{2}$ in mafic Osorno products, and negatively correlated among Calbuco products. The concentration of this oxide is roughly the same for both volcanoes. In all of the whole rock analyses, the oxides in the Calbuco fallout deposits group together with the lava flows from Calbuco while the pyroclastic and debris flows and surge deposits group together directly between the group of Osorno products and Calbuco lava flows. Relative to Calbuco lava flows and fallout deposits, the pyroclastic and debris flows and surge deposits have higher $\mathrm{MgO}, \mathrm{Fe}_{2} \mathrm{O}_{3}, \mathrm{Al}_{2} \mathrm{O}_{3}, \mathrm{TiO}_{2}$, and $\mathrm{CaO}$ and lower $\mathrm{Na}_{2} \mathrm{O}, \mathrm{K}_{2} \mathrm{O}$, and $\mathrm{N}_{2} \mathrm{O}$. The bulk rock analysis of the newly collected lava, pyroclastic, and debris flows and fallout and surge deposit samples is in agreement with the bulk rock analyses reported by López-Escobar et al. (1995). The chemical composition of andesite from Calbuco Volcano falls into a narrow range (55-60 wt\% $\mathrm{SiO}_{2}$ ) according to (LópezEscobar et al., 1995). This narrow silica range has been consistent over the life of the volcano as seen in samples from all four Calbuco units. Samples previously collected and analyzed (López-Escobar et al., 1995) were from Calbuco units 1, 2, 3, and 4, and the samples studied are representative of the andesitic eruptive products of Calbuco.

\subsection{Mineral Assemblages and Textural Description of Products}

\section{3a Basaltic Andesite}

The basaltic andesite scoria (Figure 13) is porphyritic with plagioclase, pyroxene, olivine, and magnetite phenocrysts (complete electron microprobe data of all mineral phases can be found in appendix B). Plagioclase phenocrysts are compositionally zoned, 
ranging overall from $\mathrm{An}_{33-92}$ (Figure 14), with an average low at approximately $\mathrm{An}_{60}$. Plagioclase zoning is discussed in detail in a later chapter (chapter 6). The two pyroxene varieties found are orthopyroxene and pigeonite (Figure 15). Contrary to the mineral assemblage of the andesite and the gabbroic cumulates, clinopyroxene does not occur as a phenocryst mineral phase in the basaltic andesite. Orthopyroxene, compositionally ranging from $\mathrm{En}_{69-73} \mathrm{Wo}_{2-4}$, occurs as phenocrysts which are generally rimmed with pigeonite, $\mathrm{En}_{56-59} \mathrm{Wo}_{7-9}$. There are also microphenocrysts of pigeonite with the same composition as the rims on the orthopyroxene phenocrysts. Oxide minerals in the basaltic andesite are magnetite, ranging from $\mathrm{Mt}_{50-64}$ (Figure 16). Compositionally, olivine (Figure 17) ranges from $\mathrm{Fo}_{63-79}$. Two grains analyzed were zoned with cores ranging from $\mathrm{Fo}_{78-79}$ and rims from $\mathrm{Fo}_{66-68}$, and three more are rimmed with pigeonite with the same En range as the orthopyroxene rims. Five olivine grains, ranging from Fo $70-72$, are reacting to form orthopyroxene. Only a small overall number of grains are poikilitically enclosed within other grains; there are magnetite grains enclosed in pyroxene and pyroxene grains enclosed in olivine. Comparison of the Mg-number of the mafic minerals (Figure 18) shows a bimodal distribution for olivine, from 78-80 and 6373. Orthopyroxene compositions, ranging from $71-76$, tend to be more magnesian than the lower olivine Mg-number range, with a slight overlap at the less magnesian end of the range for orthopyroxene. The majority of the orthopyroxene crystals seem to fall in between the bimodal Mg-numbers of olivine. Pigeonite rims and microphenocrysts have Mg-numbers which range from 61-64 and barely overlap the least magnesian olivine analyzed. 


\section{3b Andesite}

Calbuco andesite (Figure 19) is fine grained and porphyritic with phenocrysts of plagioclase, orthopyroxene, clinopyroxene, olivine, oxide minerals, and rare hornblende (complete electron microprobe data of all mineral phases can be found in appendix B). There are a small number of poikilitically textured grains. Poikilitic texture is observed in some of the phenocrysts in the basaltic andesite and andesite samples as well as one of the cumulate xenoliths (12-20-8; discussed below). This texture can be indicative of one of two different processes. First, it can indicate a phenocryst growth sequence, the enclosed grain being the first to have formed. The second indication could be that the enclosing grain was simply growing faster than the one it enclosed. Plagioclase is poikilitically enclosed in grains of magnetite, pyroxene, and hornblende. Orthopyroxene is poikilitically enclosed in olivine and plagioclase, and magnetite is enclosed in pyroxene. Hornblende crystals (discussed in detail in chapter 5) are unstable and are breaking down. The overall compositional range (Figure 20) of the plagioclase cores is $\mathrm{An}_{60-93}$. Pyroxene phenocrysts (Figure 21) are both orthopyroxene and clinopyroxene. The clinopyroxene is augite, compositionally ranging from $\mathrm{En}_{43-46} \mathrm{Wo}_{38-42}$. Orthopyroxene phenocrysts range from $\mathrm{En}_{54-75} \mathrm{Wo}_{2-5}$ in composition and some are rimmed with pigeonite and sub-calcic augite $\left(\mathrm{En}_{49-59} \mathrm{Wo}_{5-16}\right)$. Olivine phenocrysts (Figure 22) in the andesite have the same compositional range (Fo $\left.\mathrm{F}_{6-79}\right)$ as the olivine phenocrysts found in the basaltic andesite. Similar to the olivine found in the basaltic andesite, the olivine in the andesite $\left(\mathrm{Fo}_{63-75}\right)$ is reacting to from orthopyroxene. The composition of the plagioclase phenocrysts ranges from $\mathrm{An}_{2 \mathrm{l}-94}$, with the more calcic compositions found predominantly in the cores of the phenocrysts. Oxide minerals are 
magnetite, ranging from $\mathrm{Mt}_{49-68}$ (Figure 23). The Mg-number of the mafic minerals, Figure 24, ranges from 64-69 and 75-80 for olivine, 67-71 for hornblende, 72-76 for clinopyroxene, 56-77 for orthopyroxene, with the majority between $65-74$, and 57-63 for pigeonite rims. Olivine shows a bimodal distribution, as it does in the basaltic andesite, with the less magnesian compositions nearly overlapping the hornblende compositions. Clinopyroxene tends to overlap the majority of the orthopyroxene compositions and also tends to overlap the gap between olivine Mg-numbers. Pigeonite is much less magnesian than the other minerals with the exception of a few orthopyroxene grains.

\section{3c Crystal Clusters}

Anhydrous clusters of mafic minerals (Figure 25) are found entrained in the andesite and basaltic andesite erupted from Calbuco Volcano. These clusters are aggregates of minerals which are also found as phenocrysts in the lava and as coarse grains in the cumulate xenoliths. Crystal clots like these are common in volcanoes throughout the world, both calc-alkaline (examples include Scarfe and Fujii (1987), Garcia and Jacobson (1979), Castro and Stephens (1992), Sial et al. (1998)) and tholeiitic (Amma-Miyasaka and Nakagawa, 2003). According to Garcia and Jacobson (1979), these crystal clots must have no interstitial glass present. López-Escobar et al. (1995) have termed the mineral aggregates which resulted from hornblende breakdown in Calbuco Volcano as crystal clots, however, Garcia and Jacobson (1979) have made a distinction between the mineral aggregates and hornblende breakdown products based on the textures found in each. The crystal clusters found in Calbuco lavas have very different textures from the hornblende breakdown products found, and are therefore can be assumed to be genetically different. Although these clusters are coarse grained 
mineral aggregates, they typically have some interstitial glass present and therefore the majority can not be termed "crystal clots" in the terminology of Garcia and Jacobson (1979).

\section{3c.i Mineral Assemblage and Textural Description}

Based on the mineral assemblage of these crystal clusters, they have been grouped in to four categories, or types; types A, B, C, and D (Table 3). Types A and B are further divided in to sub categories A1, A2, B1, and B2 (complete electron microprobe data of all mineral phases can be found in appendix B). All categories of the A and B type crystal clusters have the same basic mineral assemblage of orthopyroxene, plagioclase, and magnetite. Type A1 clusters (Figure 26, Figure 27, and Figure 29) are made up of only this basic assemblage (orthopyroxene $\mathrm{En}_{54-73} \mathrm{Wo}_{2-5}$; plagioclase $\mathrm{An}_{42-91}$; magnetite $\mathrm{Mt}_{42-92}$ ) with interstitial glass sometimes present. The plagioclase grains may or may not be zoned. Type A2 clusters (Figure 26, Figure 27, Figure 28, Figure 29) have orthopyroxene $\left(\mathrm{En}_{67-74} \mathrm{Wo}_{3-4}\right)$, plagioclase $\left(\mathrm{An}_{61-91}\right)$, magnetite $\left(\mathrm{Mt}_{56-69}\right)$, in addition to olivine $\left(\mathrm{Fo}_{68-75}\right)$. The olivine is typically reacting to form orthopyroxene. Again, there may or may not be interstitial glass present and the plagioclase may or may not be zoned. Type B clusters differ from type A by the presence of clinopyroxene. Type B1 clusters (Figure 26, Figure 27, Figure 29) have clinopyroxene $\left(\mathrm{En}_{42-45} \mathrm{Wo}_{38-43}\right)$, orthopyroxene $\left(\operatorname{En}_{65-71} \mathrm{Wo}_{2-3}\right)$, plagioclase $\left(\mathrm{An}_{67-91}\right)$, and magnetite $\left(\mathrm{Mt}_{57-68}\right)$, while type $\mathrm{B} 2$ clusters (Figure 26, Figure 27, Figure 28, Figure 29) have clinopyroxene $\left(\operatorname{En}_{41-46} \mathrm{Wo}_{40-42}\right)$, orthopyroxene $\left(\mathrm{En}_{64-72} \mathrm{Wo}_{2-3}\right)$, plagioclase $\left(\mathrm{An}_{64-91}\right)$, magnetite $\left(\mathrm{Mt}_{60-71}\right)$, and olivine $\left(\mathrm{Fo}_{67-71}\right)$. Interstitial glass is sometimes present in both type B1 and B2 clusters, and the plagioclase may or may not be zoned. Types $\mathrm{C}$ and $\mathrm{D}$ are distinct from the first groups in 
that they do not typically have interstitial glass. Type C clusters (Figure 26, Figure 28) are made up of large, zoned, high An plagioclase $\left(\mathrm{An}_{84-92}\right)$ and moderate to high Fo olivine $\left(\mathrm{Fo}_{66-80}\right)$. This olivine may or may not be reacting to form orthopyroxene. Type D clusters (Figure 26) are aggregates of only large zoned plagioclase crystals $\left(\mathrm{An}_{87-90}\right)$. Mg-numbers of the mafic minerals within all cluster types are generally overlapping (Figure 30).

\section{3c.ii Chemical Composition of Volcanic Glass}

Quenched volcanic glass is found interstitially in the crystal clusters and also trapped in plagioclase crystals (Figure 31). The glass is clear and brown, ranging in shades from medium to dark. Analysis of the interstitial glass and glass trapped within plagioclase grains (Figure 32) was done on cluster types A1, B1, B2, and C in one representative lava sample (12-20-7a). The interstitial glass is rhyodacitic to rhyolitic in composition, ranging from $64-75 \mathrm{wt} \% \mathrm{SiO}_{2}$. The $\mathrm{SiO}_{2}$ range for the interstitial glass for type $\mathrm{A} 1$ clusters is $71-74 \mathrm{wt} \%$, for type $\mathrm{B} 1$ clusters the $\mathrm{SiO}_{2}$ range is $65-74 \mathrm{wt} \%$, type $\mathrm{B} 2$ clusters range from 64-75 wt $\% \mathrm{SiO}_{2}$, and type $\mathrm{C}$ clusters have $73-74 \mathrm{wt} \% \mathrm{SiO}_{2}$ glass. The composition of the glass trapped in the plagioclase crystals is detailed in a later chapter dealing specifically with plagioclase (chapter 6) however it is compositionally similar to the interstitial glass (complete electron microprobe data of all volcanic glass can be found in appendix B).

\section{3d Gabbroic Xenoliths}

Evolved calc-alkaline volcanic rocks originate from fractionation of a crystallizing assemblage within the magma chamber. The fractionated crystal assemblage is preserved as cumulate "piles" and can be subsequently entrained in the 
volcanic eruption as cumulate xenoliths. An alternative origin for gabbroic xenoliths is that they are derived from plutonic basement rock. Gabbroic xenoliths are fairly common among subduction zone volcanoes (some examples include Volcán Calbuco, Chile, Hickey-Vargas et al., 1995 and McKelvey and Hickey-Vargas, 2004; Volcán San Pedro, Chile, Costa et al., 2002; Mt. Pelée, Lesser Antilles, Pichavant et al., 2002 and Fichaut et al., 1989; Mt. St. Helens, Cascades, Medicine Lake, California, Arenal, Costa Rica, Costa et al, 2002; and several localities in Japan, Yagi and Takeshita, 1987 and Costa et al., 2002). Three xenolith samples with similar mineral assemblages have been studied for this project, in addition to previous studies done on several xenoliths (Abdollahi, 1990). The specific samples chosen differ from each other as to the degree of hornblende breakdown; sample 12-19-18 has the least broken down hornblende, sample 12-20-3 has the most advanced hornblende breakdown, and the degree of hornblende breakdown in sample $12-20-8$ is intermediate between the two.

\section{3d.i Mineral Assemblage and Textural Description}

Sample 12-19-18 (Figure 33) consists of coarse grains of hornblende, plagioclase, olivine, orthopyroxene, magnetite and minor ilmenite, rare clinopyroxene, and ironsulfide minerals. The hornblende, discussed in detail in chapter 5 , is pargasitic and the xenolith is composed of only one very large hornblende grain poikilitically enclosing all other mineral grains. In this xenolith, the hornblende breakdown is very slight, however where present this breakdown is forming symplectites (Abdollahi, 1990). Plagioclase grains are approximately $0.05-5 \mathrm{~mm}$ in size, unzoned, and are subhedral to anhedra' (Abdollahi, 1990) and range in composition from An90-97 (Figure 34). Orthopyroxene is approximately $0.5-4 \mathrm{~mm}$ in size and the composition ranges from $\mathrm{En}_{71-75} \mathrm{Wo}_{1-2}$ (Figurs 
35). Only one clinopyroxene grain (Figure 35) was analyzed which was augite $\left(\mathrm{En}_{43} \mathrm{Wo}_{43}\right)$. Olivine grains (Figure 36) range from $\mathrm{Fo}_{70-73}$ and are approximately 0.5-3 $\mathrm{mm}$ in size. The olivine in this xenolith is reacting in two different ways (Figure 37), the first of which is a reaction to orthopyroxene. This reaction typically takes place at a grain boundary between the olivine and plagioclase and sometimes includes vermicular magnetite. The second type of olivine reaction results in the crystallization of plagioclase, orthopyroxene, and magnetite. These two types of olivine reaction are the same as the reaction observed in the lava samples and crystal clusters. Compositionally, magnetite ranges from $\mathrm{Mt}_{52-100}$ and ilmenite from $\mathrm{Ilm}_{70-90}$ (Figure 38) and both are approximately $0.05-1 \mathrm{~mm}$ in size. Iron sulfide minerals were not quantitatively analyzed, however an EDS image indicates that the minerals are predominantly made up of Fe and S (Figure 39), and have been identified in reflected light as pyrrhotite and chalcopyrite (Macfarlane, personal communication). Orthopyroxene Mg-numbers range from 73-77, clinopyroxene Mg-number is 76, olivine Mg-numbers range from 72-74, and hornblende ranges are 62-70 (Figure 40). Since the hornblende in this sample is one large grain, the variation in $\mathrm{Mg}$-number over several different points indicates compositional zoning. The orthopyroxene, clinopyroxene, and olivine have overlapping Mg-numbers, which does not overlap the range of hornblende numbers.

Sample 12-20-3 (Figure 33) is medium to coarse grained and has hornblende, phlogopite, plagioclase, olivine, orthopyroxene, rare clinopyroxene, magnetite, minor ilmenite, accessory apatite, and glass (discussed in following section). This xenolith has a granoblastic matrix of plagioclase supporting large mesh textured crystals of hornblende, olivine, orthopyroxene, and clinopyroxene. These mesh textured minerals 
are several orders of magnitude larger than the matrix plagioclase. The metamorphic texture of this particular sample is probably due to the more extensive breakdown of hornblende and subsequent release of water. Plagioclase grains are approximately 0.25 $\mathrm{mm}$ in size and range from $\mathrm{An}_{70-93}$ (Figure 34) compositionally, with a few grains as sodic as $\mathrm{An}_{56}$. The plagioclase is typically unzoned with only rare crystals displaying zoning. Hornblende, discussed in detail in chapter 5 , is one of the mesh textured minerals and is pargasitic and its breakdown results in symplectites. Magnetite and ilmenite (Figure 38) range compositionally from $\mathrm{Mt}_{56-93}$ and $\mathrm{Ilm}_{66-73}$, and approximately 0.05 to $0.3 \mathrm{~mm}$ in size. Olivine is another mesh textured mineral which ranges compositionally from $\mathrm{Fo}_{71-74}$ (Figure 36). There are only three analyzed clinopyroxene grains which are augite $\left(\mathrm{En}_{42-43} \mathrm{Wo}_{42-45}\right)$, and orthopyroxene ranges from $\mathrm{En}_{71-77} \mathrm{Wo}_{1-2}$ (Figure 35). Phlogopite grains (Figure 41) are euhedral to subhedral and bladed, ranging in size from 0.25-0.5 mm. Mg-numbers of the mafic minerals (Figure 40) are 73-78 for orthopyroxene, 72-78 for clinopyroxene, 71-74 for olivine, 67-75 for hornblende, and 7779 for phlogopite. Orthopyroxene and clinopyroxene have overlapping Mg-number ranges. Olivine and hornblende Mg-numbers are lower than both pyroxene types, but do overlap the pyroxene ranges at the low magnesian end of the range. The more magnesian end of the hornblende Mg-numbers overlap olivine Mg-numbers, but the total hornblende range continues to less magnesian compositions. The phlogopite Mg-numbers are higher than all other ranges overlapping the most magnesian ortho- and clinopyroxene.

Sample 12-20-8 (Figure 33) is comprised of coarse grains of plagioclase, hornblende, orthopyroxene, olivine, magnetite, and glass (discussed in following section). Clinopyroxene is absent. Plagioclase grains are approximately $0.5-5 \mathrm{~mm}$ in size and 
compositionally range from $\mathrm{An}_{73-92}$ (Figure 34). Magnetite ranges in composition from $\mathrm{Mt}_{61-74}$ (Figure 38) and are 0.06-0.75 $\mathrm{mm}$ in size. The hornblende, discussed in detail in chapter 5, is pargasitic and breakdown of the grains results in symplectic textures. Olivine is approximately $0.06-1.5 \mathrm{~mm}$ in size and ranges from $\mathrm{Fo}_{67-72}$ (Figure 36). Orthopyroxene grains are 0.03-0.3 $\mathrm{mm}$ in size and range from $\mathrm{En}_{71-72} \mathrm{Wo}_{1-2}$ (Figure 35). Interstitial pockets of minerals exhibiting breakdown textures are found between large plagioclase and hornblende grains involving all minerals (Figure 42). Surrounding the central coarse grains are five concentric reaction bands (Figure 43) consisting of plagioclase, olivine, orthopyroxene, minor magnetite and ilmenite, and one hornblende grain. In these reaction bands, hornblende is pargasitic, similar in composition to the coarse grains, magnetite ranges from $\mathrm{Mt}_{64-69}$, ilmenite ranges from $\mathrm{Ilm}_{72-73}$, plagioclase ranges from $\mathrm{An}_{79-94}$, orthopyroxene ranges from $\mathrm{En}_{69-76} \mathrm{Wo}_{1-3}$, and olivine ranges from Fo $_{67-76}$. The ranges of $\mathrm{Mg}$-numbers in this sample (Figure 40) are 72-74 for orthopyroxene, 68-72 for olivine, and 64-71 for hornblende. The Mg-numbers for olivine and hornblende overlap with a few hornblende grains which are less magnesian. The orthopyroxene is more magnesian than the olivine or hornblende.

In comparing the Mg-numbers of the individual minerals between the three cumulate xenolith samples (Figure 40), the Mg-numbers of the orthopyroxene in 12-1918 and $12-20-3$ overlap but the orthopyroxene in $12-20-8$ is less magnesian than in the other two cumulate xenoliths. The overall range of the Mg-numbers of the clinopyroxene grains in all three samples overlaps the overall $\mathrm{Mg}$-number range of the orthopyroxene in all three samples. The majority of the Mg-numbers of the olivine in all three samples overlaps the less magnesian end of the ortho- and clinopyroxene ranges with a few less 
magnesian grains. The olivine in sample 12-19-18 is more magnesian than the olivine in 12-20-8, and the olivine in 12-20-3 overlaps the ranges of the other two samples. Overall, the Mg-numbers of the hornblende in the three samples is overlapping, the majority of which overlap the less magnesian end of the olivine Mg-numbers. The Mgnumbers of the phlogopite is more magnesian than the range of any of the other mafic minerals (complete electron microprobe data of all mineral phases can be found in appendix B). Of the three xenoliths studied in detail, 12-19-18 is the only sample with iron-sulfide minerals, however it is also the only sample without glass. Olivine is reacting to form orthopyroxene, oxides, and plag in 12-19-18 and 12-20-8, which both have igneous textures, and not in 12-20-3, which has a granoblastic texture.

\section{3d.ii Chemical Composition of Glass}

Quenched glass is found in the cumulate gabbroic xenoliths both interstitially and trapped in plagioclase and pyroxene crystals. Pyroxene crystals containing glass are relatively few in number. The glass is similar in appearance to the glass in the crystal clusters, clear and medium to dark brown (Figure 44). Analysis of interstitial glass was done on two xenolith samples (12-20-3, 12-20-8); plagioclase and pyroxene trapped glass was analyzed on one sample (12-20-3). Interstitial glass is dacitic to rhyolitic in composition, ranging from $61-74 \mathrm{wt} \% \mathrm{SiO}_{2}$, overlapping the compositional range of the crystal clusters described above (Figure 45). Glass found trapped inside plagioclase grains is detailed in a later chapter (chapter 6), and does however overlap compositionally with the interstitial glass although the $\mathrm{SiO}_{2}$ range does not quite stretch as high or low as the interstitial $\mathrm{SiO}_{2}$ range. Glass within the pyroxene has a very narrow compositional range of $69-70 \mathrm{wt} \% \mathrm{SiO}_{2}$, which is likely due to the scarcity of pyroxene crystals 
containing glass and the subsequent low number of analyses (complete electron microprobe data of all volcanic glass can be found in appendix B).

There is a general trend in the glass, both interstitial and trapped within plagioclase and pyroxene, toward a dacitic to rhyolitic composition. Pyroxene grains in the crystal clusters record only a rhyolitic composition, however, the range is still within the upper limits of the overall $\mathrm{SiO}_{2}$ range. One reason for this may be that some pyroxene grains have crystallized only from highly evolved magma, however the similarity in the composition of all pyroxene grains in all eruptive products tends to point away from this as an explanation for the glass compositional range. An alternative explanation is that the high $\mathrm{SiO}_{2}$ content is due to post entrapment crystallization.

\subsection{Summary}

Andesite is the predominant volcanic product from Calbuco Volcano, although rare basaltic andesite has been erupted. Entrained in the lava are crystal clusters and cumulate gabbroic xenoliths with the same mineral assemblage as the lava. The andesite has phenocrysts of zoned plagioclase, orthopyroxene, magnetite, rare hornblende and minor olivine and clinopyroxene. The rare hornblende phenocrysts are breaking down. They have opacite rims and black microcrystalline patches of breakdown reaction products. The basaltic andesite has phenocrysts of zoned plagioclase, orthopyroxene, olivine, magnetite, and microphenocrysts and phenocryst rims of pigeonite. Olivine is found in both andesite and basaltic andesite. In the andesite the grains are few and in reaction, however in the basaltic andesite olivine is a major phase and the majority of the phenocrysts are intact. Hornblende and clinopyroxene are not found in the basaltic andesite. The entrained crystal clusters have the same overall mineral assemblage as the 
phenocryst assemblage in the andesite (zoned and unzoned plagioclase, orthopyroxene, clinopyroxene, olivine, and magnetite) and rhyodacitic to rhyolitic glass. Hornblende is not found in the crystal clusters. Entrained cumulate gabbroic xenoliths also have the same overall mineral assemblage as the phenocryst assemblage in the andesite (unzoned plagioclase, orthopyroxene, magnetite, hornblende, and rare clinopyroxene), with the presence of accessory minerals, apatite, Fe-sulfides, phlogopite, and ilmenite, which are not found in the andesite, and dacitic to rhyolitic glass. In contrast to the low modal abundance of hornblende phenocrysts in the lava, hornblende is abundant in the gabbroic xenoliths and occurs without opacite rims. The hornblende in the xenoliths does however have the same black microcrystalline breakdown reaction products found in the phenocrysts. Major element chemistry of individual mineral phases shows overlapping compositions for respective phenocryst phases and crystals in gabbroic xenoliths and crystal clusters. Ranges of Mg-numbers of the individual mafic mineral phases are also generally overlapping. 






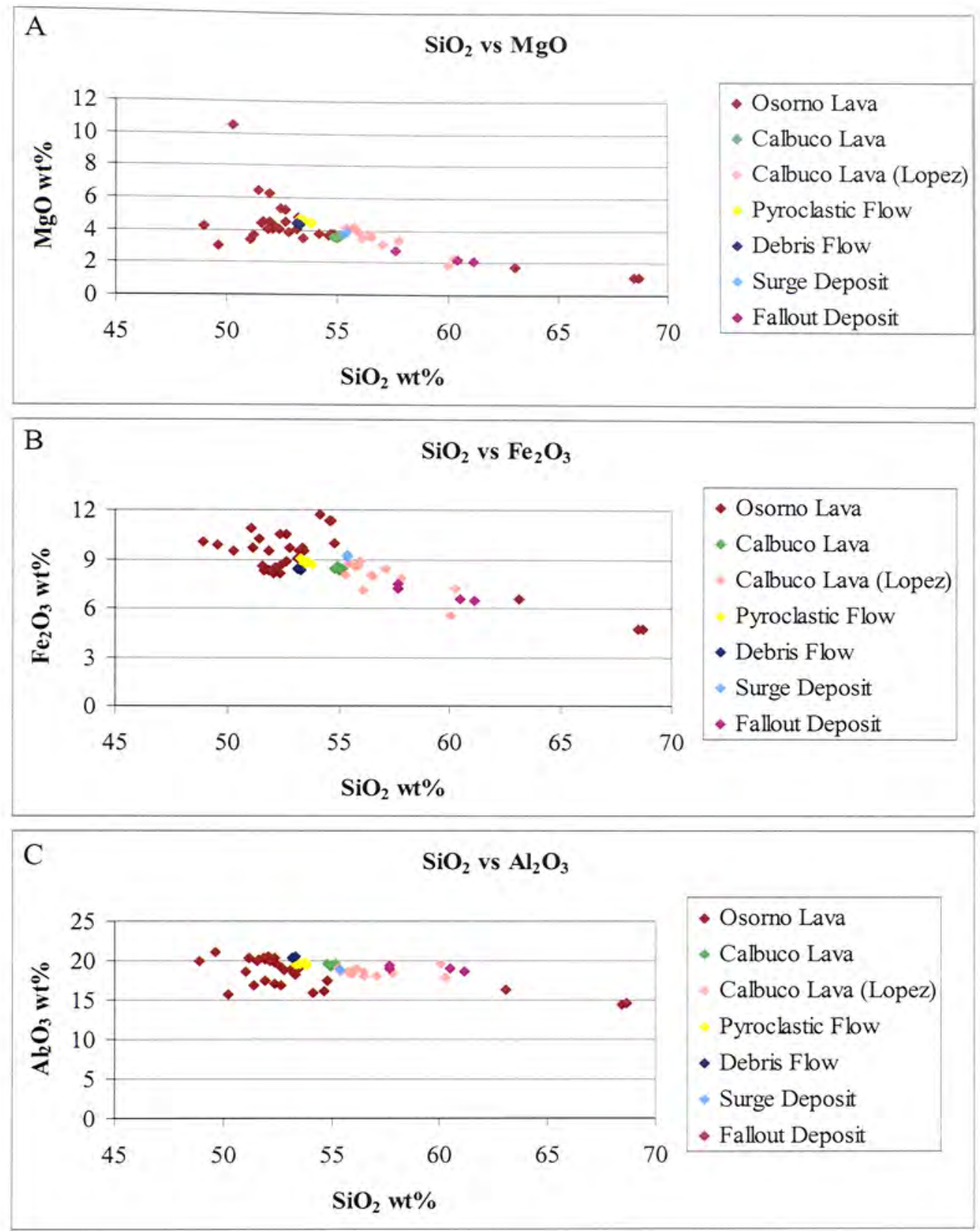

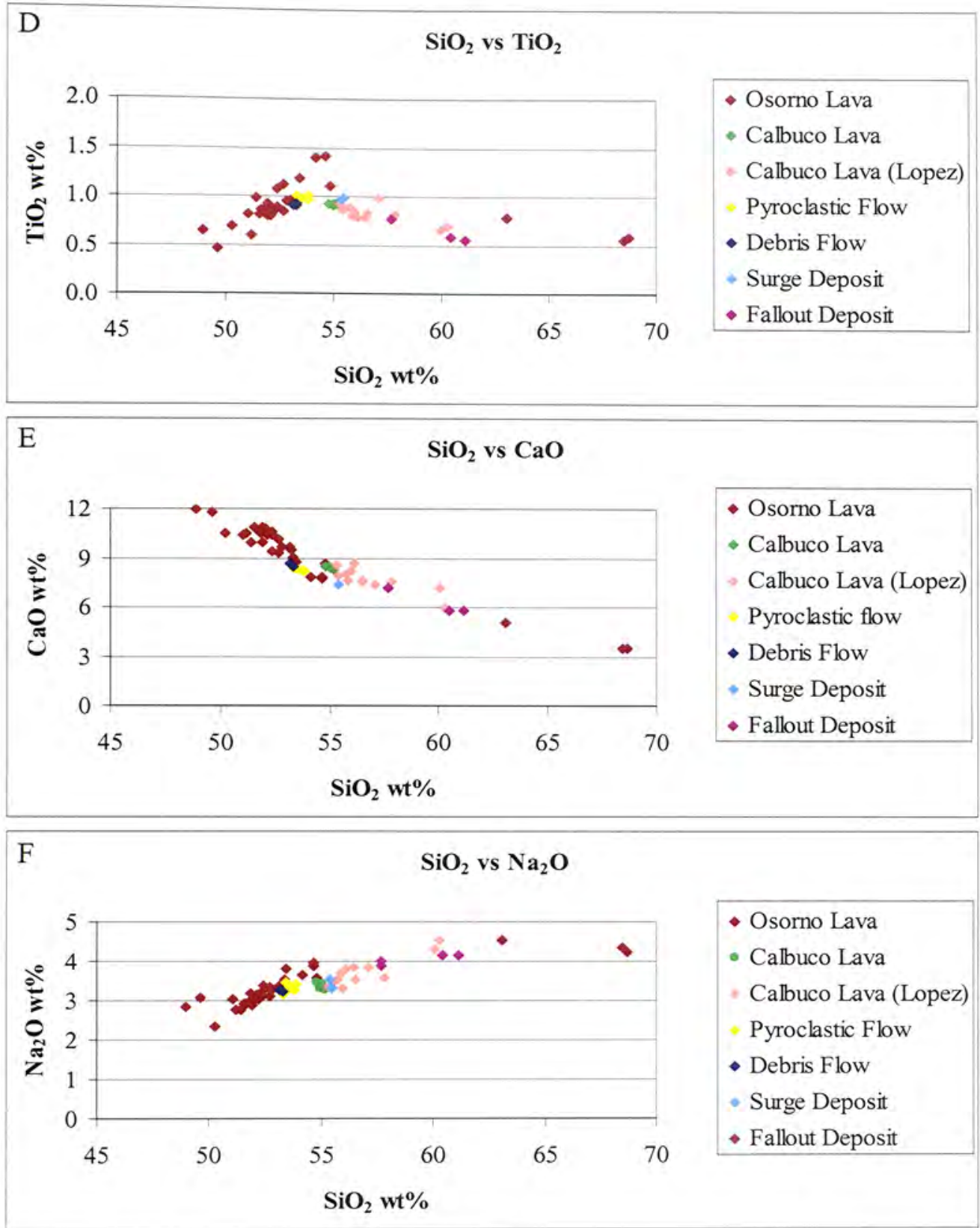

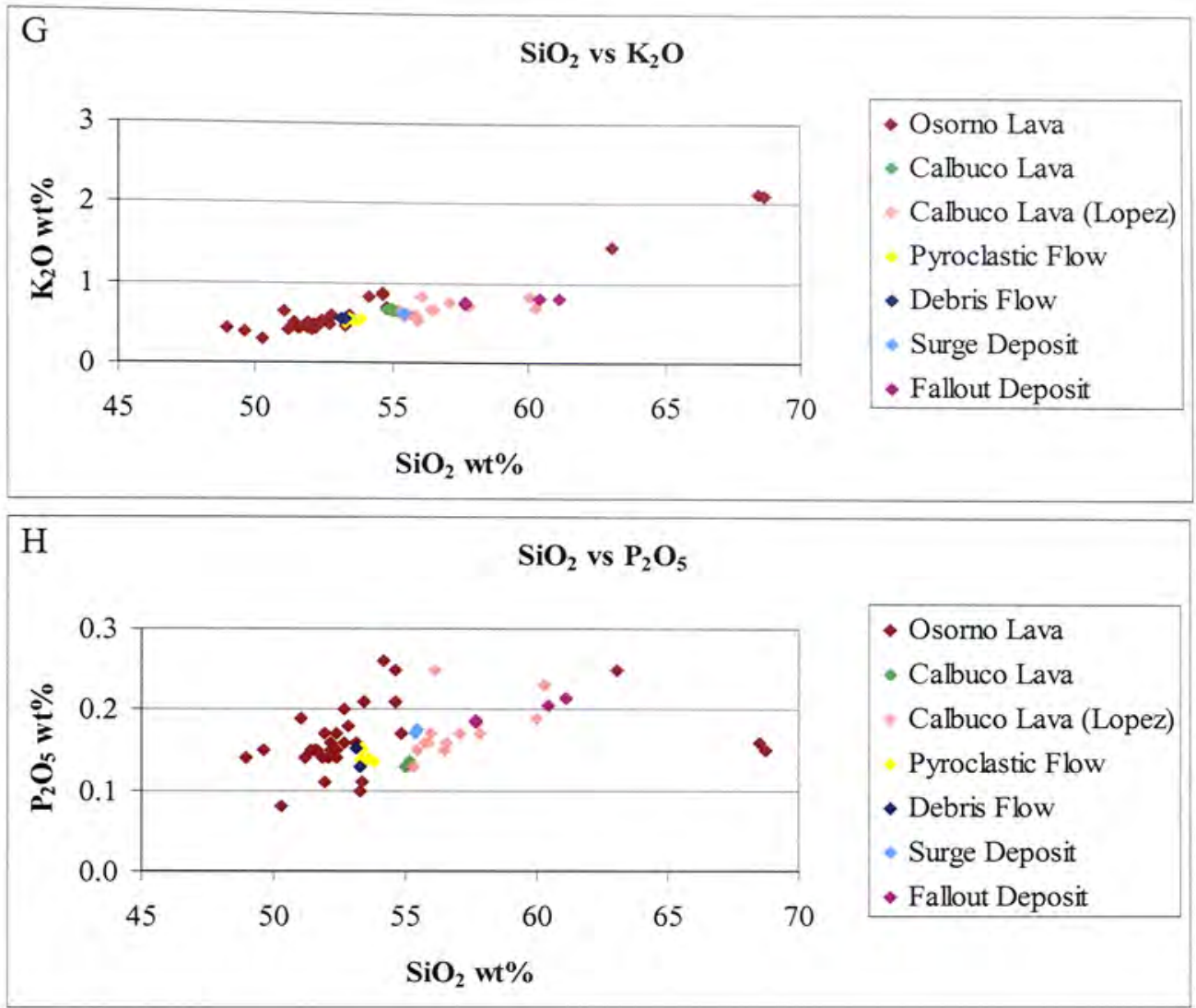

Figure 12: Bulk rock oxide plots.

Bulk rock $\mathrm{MgO}, \mathrm{Fe}_{2} \mathrm{O}_{3}, \mathrm{Al}_{2} \mathrm{O}_{3}, \mathrm{TiO}_{2}, \mathrm{CaO}, \mathrm{Na}_{2} \mathrm{O}, \mathrm{K}_{2} \mathrm{O}$, and $\mathrm{P}_{2} \mathrm{O}_{5}$ wt $\%$ versus $\mathrm{SiO}_{2}$ wt $\%$. Bulk rock analyses of newly collected lava blocks, pyroclastic and debris flow deposits, and surge and fallout deposits from Calbuco, in addition to previously reported Calbuco and Osorno lava blocks (López-Escobar et al., 1995). 

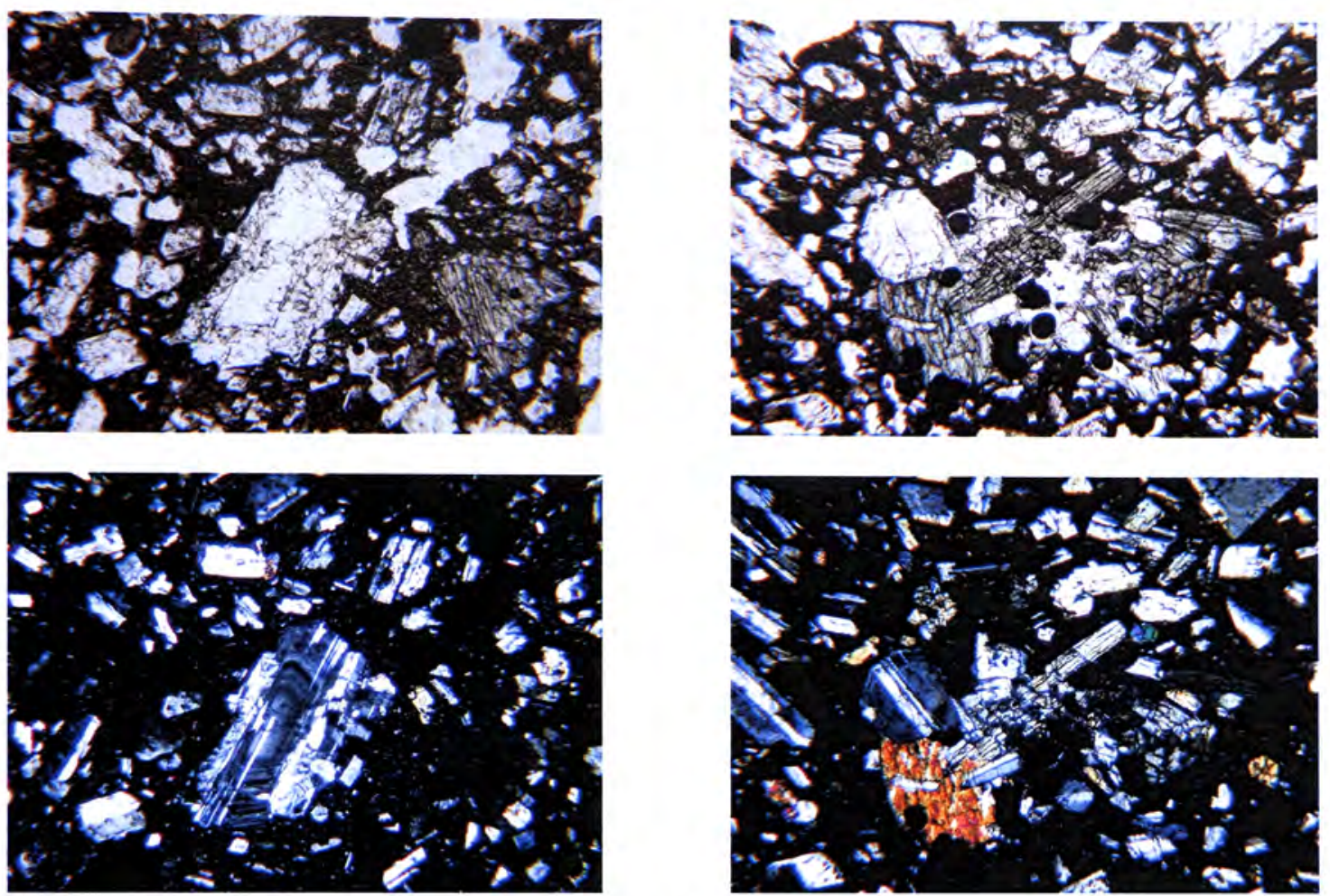

Figure 13: Photomicrographs of basaltic andesite.

Photomicrographs in plane and cross polarized light of newly collected basaltic andesite. Field of view is $2.8 \mathrm{~mm}$. 


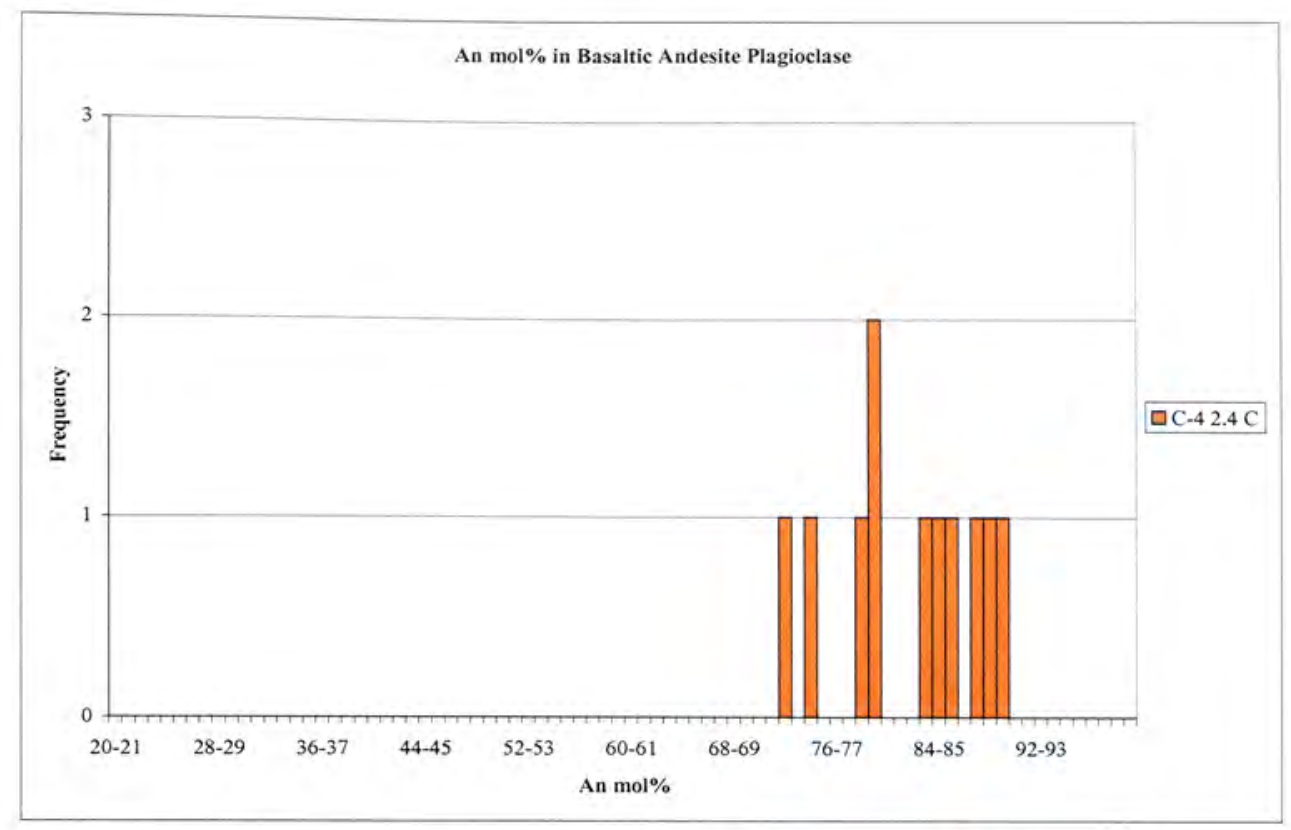

Figure 14: Histogram of An mol\% versus frequency of plagioclase phenocryst cores in basaltic andesite.

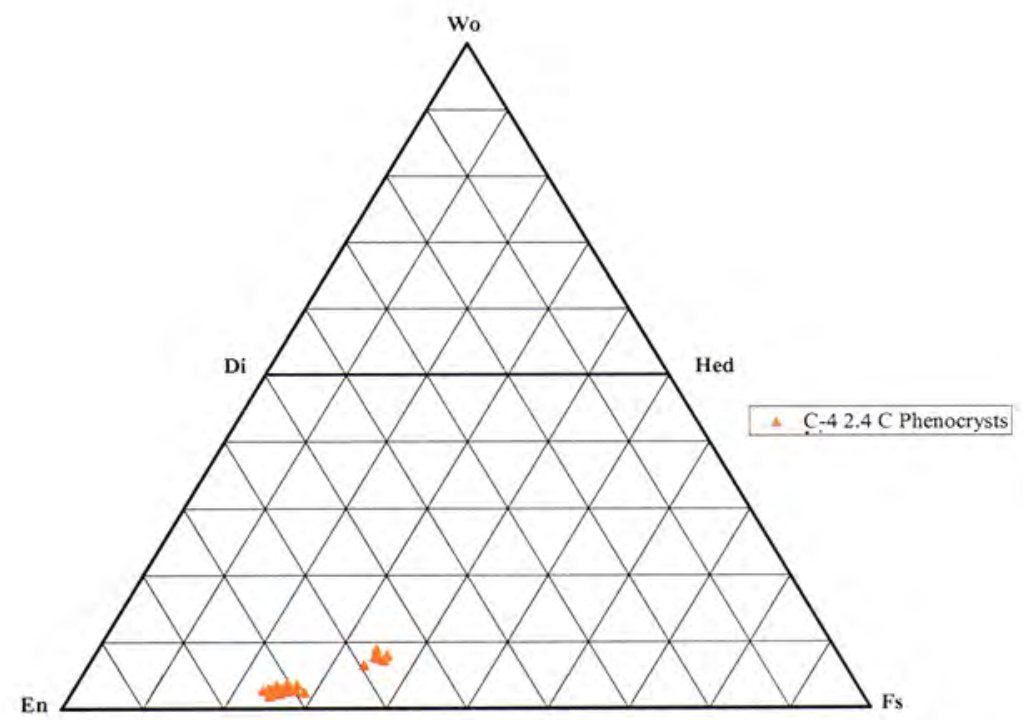

Figure 15: Ternary plot showing the composition of orthopyroxene phenocrysts in basaltic andesite. 


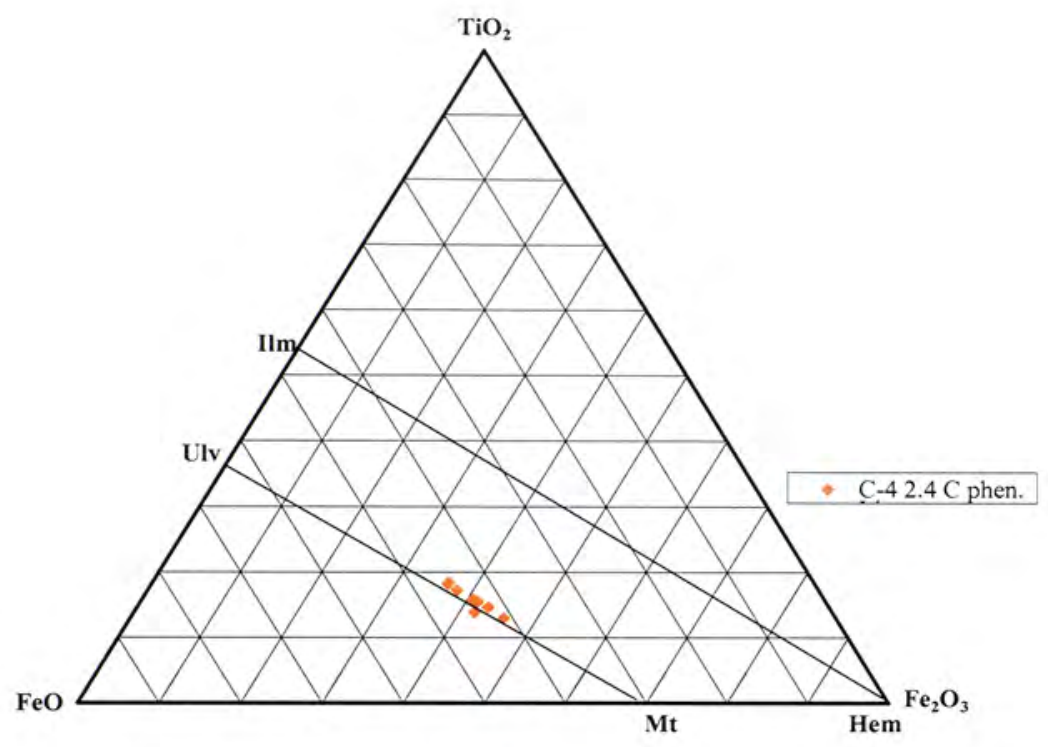

Figure 16: Ternary plot showing the composition of magnetite phenocrysts in basaltic andesite.

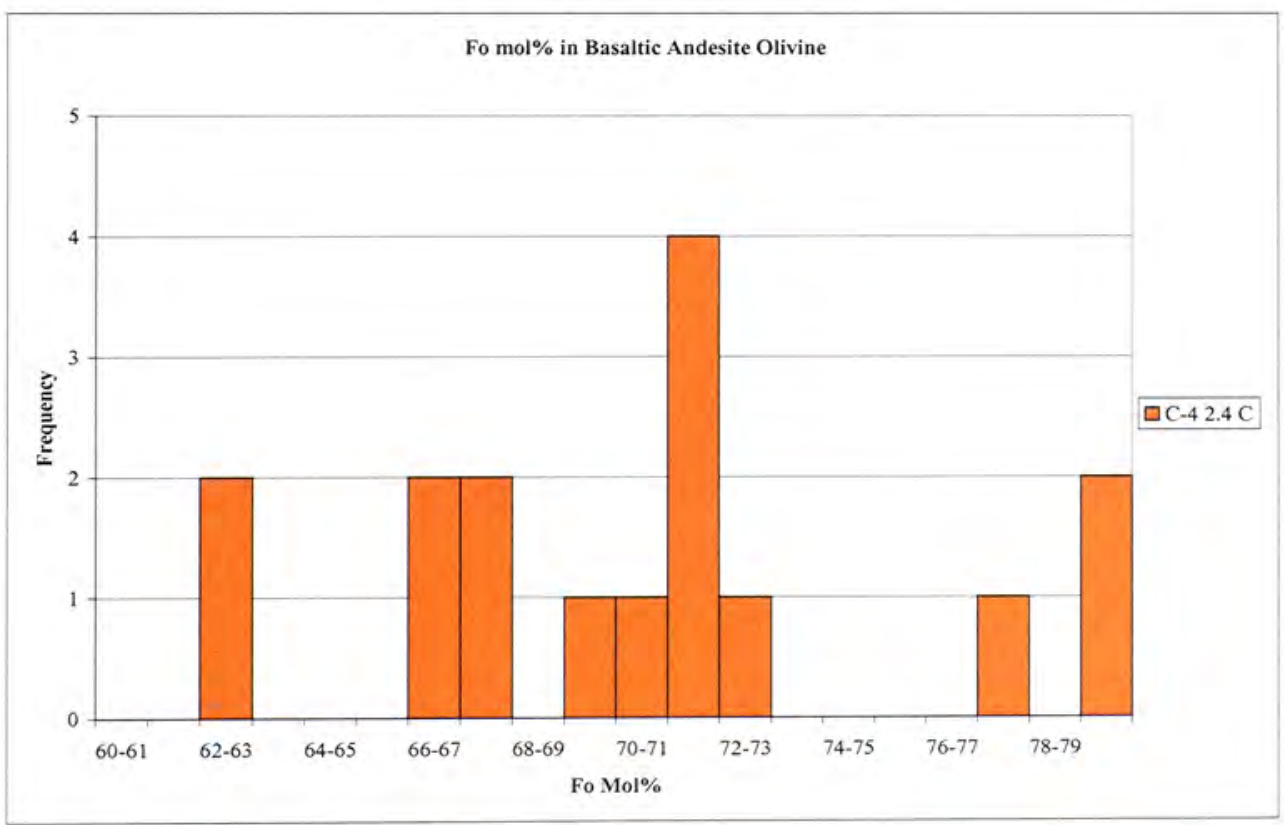

Figure 17: Histogram of Fo mol\% versus frequency of olivine phenocrysts in basaltic andesite. 


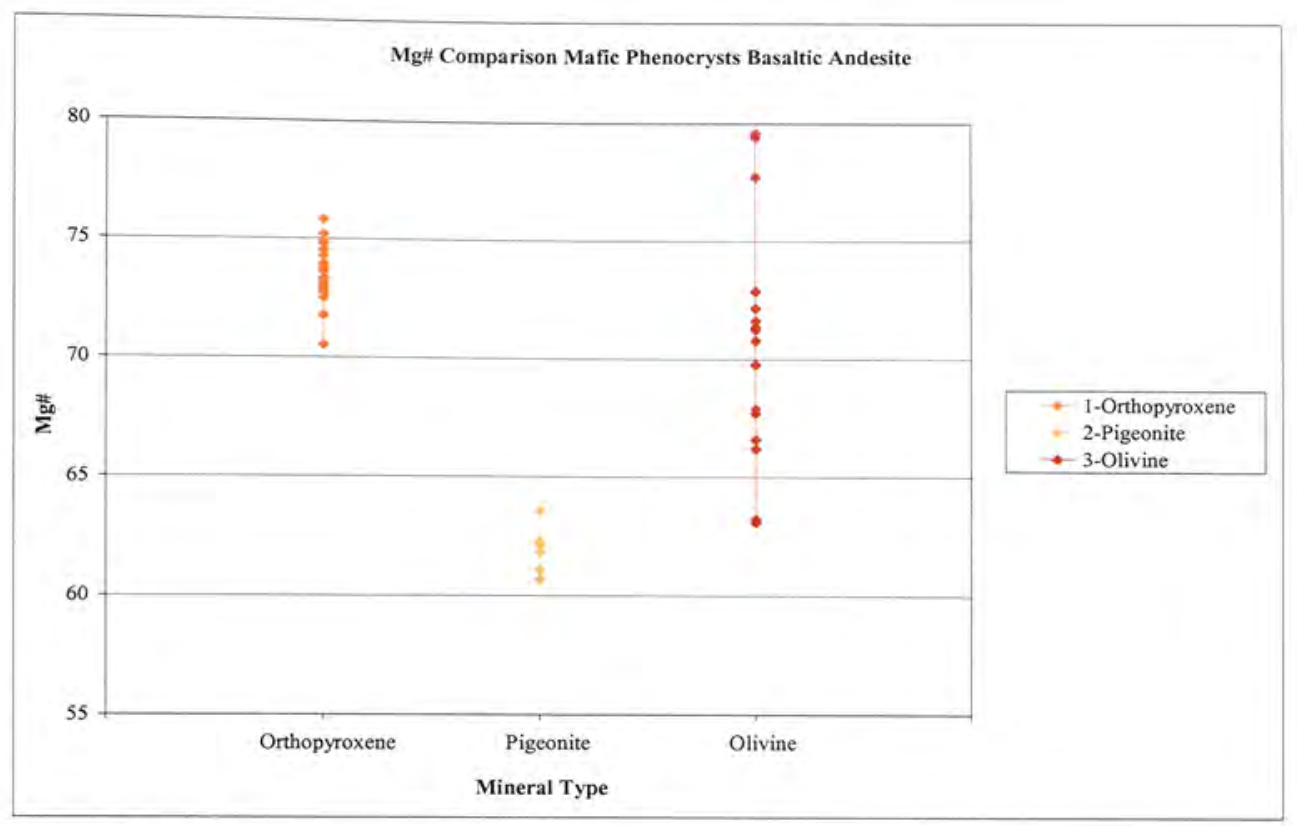

Figure 18: Basaltic andesite mafic mineral Mg\#.

Plot of mineral type versus Mg-number ranges of mafic minerals (orthopyroxene, pigeonite, and olivine) in basaltic andesite. 

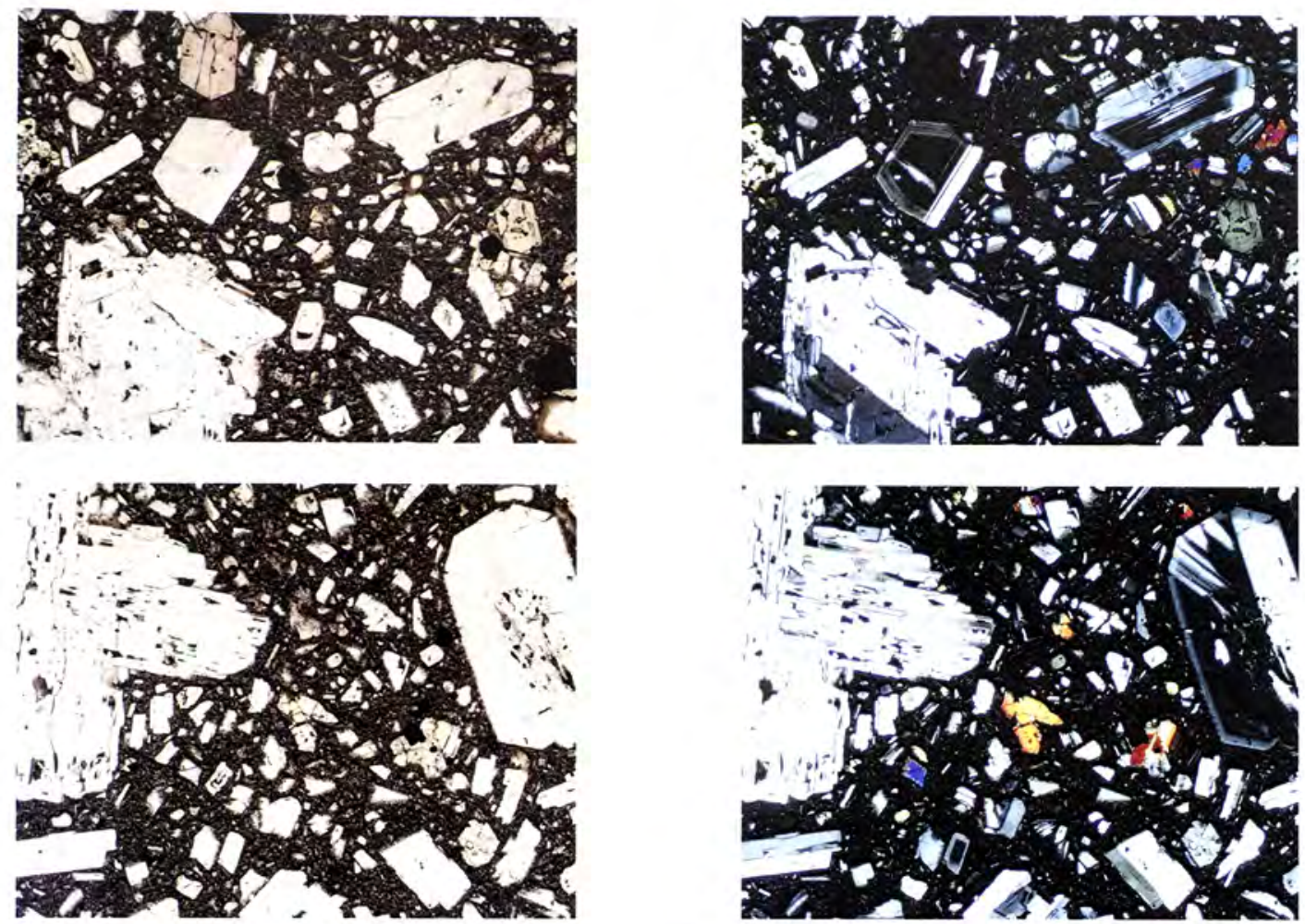

Figure 19: Photomicrographs of andesite.

Photomicrographs in plane and cross polarized light of andesite. Field of view is $2.8 \mathrm{~mm}$. 


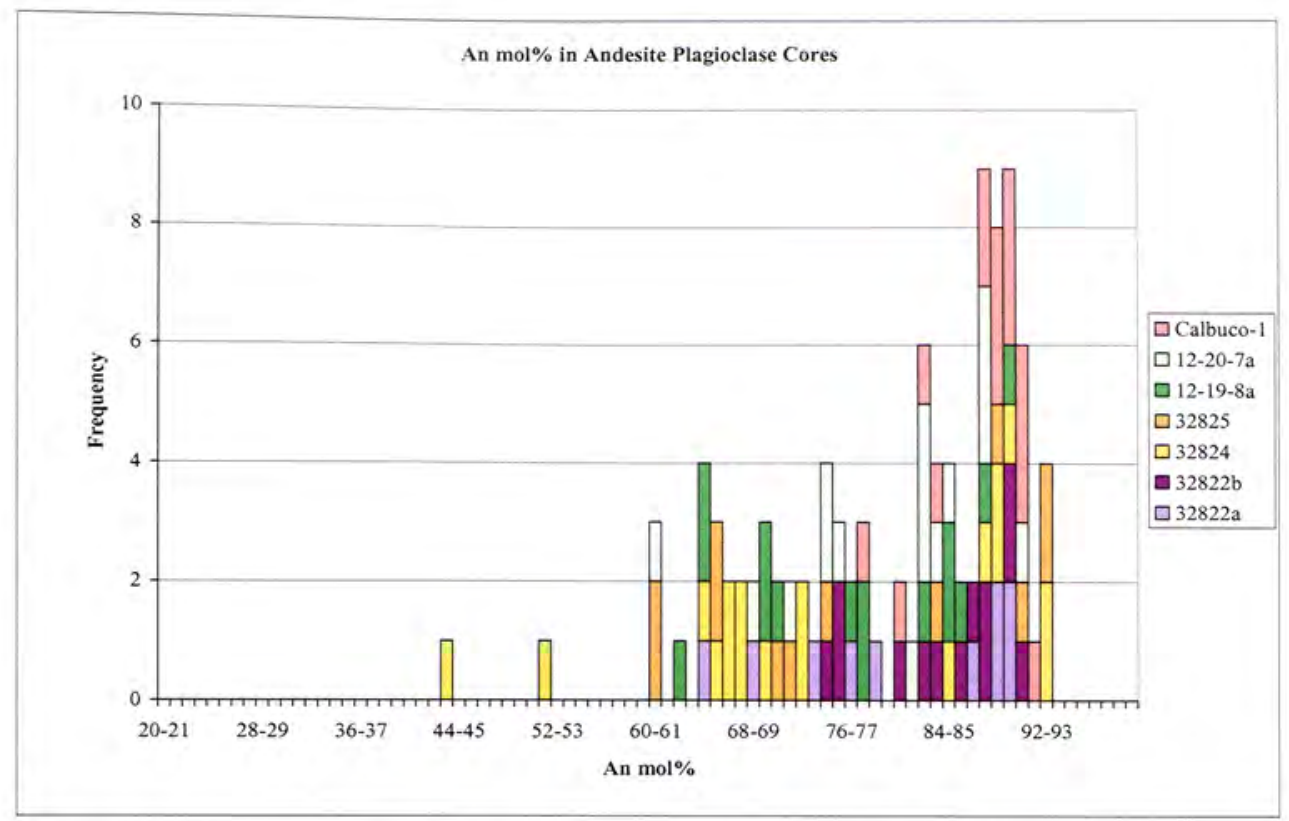

Figure 20: Histogram of An mol\% versus frequency of plagioclase phenocryst cores in andesite samples.

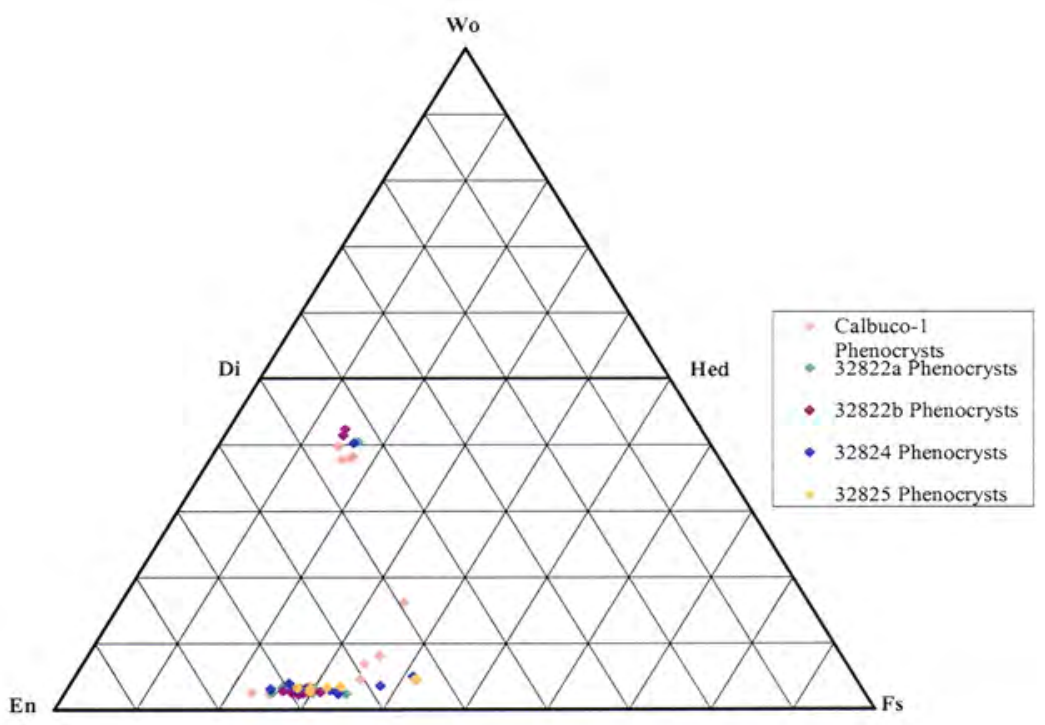

Figure 21: Ternary plot showing the composition of orthopyroxene and clinopyroxene phenocrysts in andesite. 


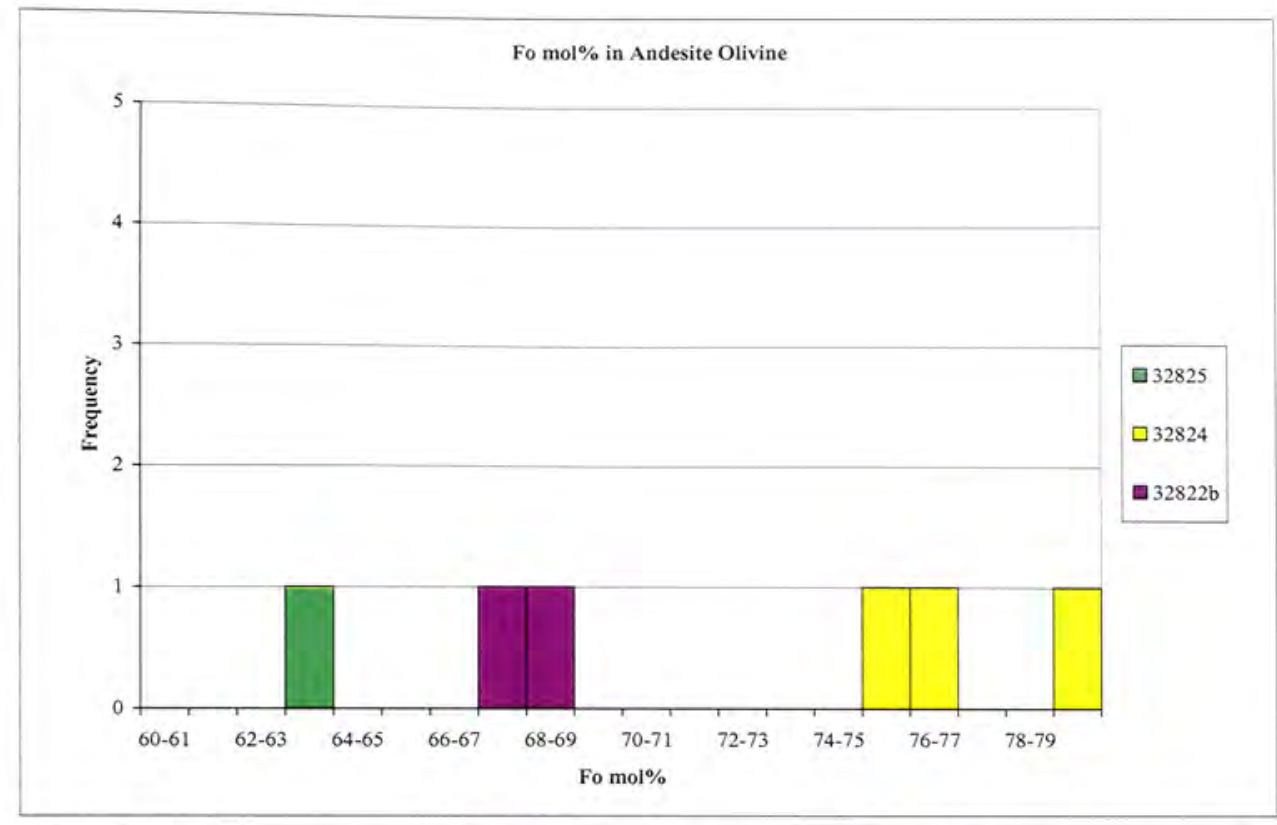

Figure 22: Histogram of Fo mol\% versus frequency of olivine phenocrysts in andesite.

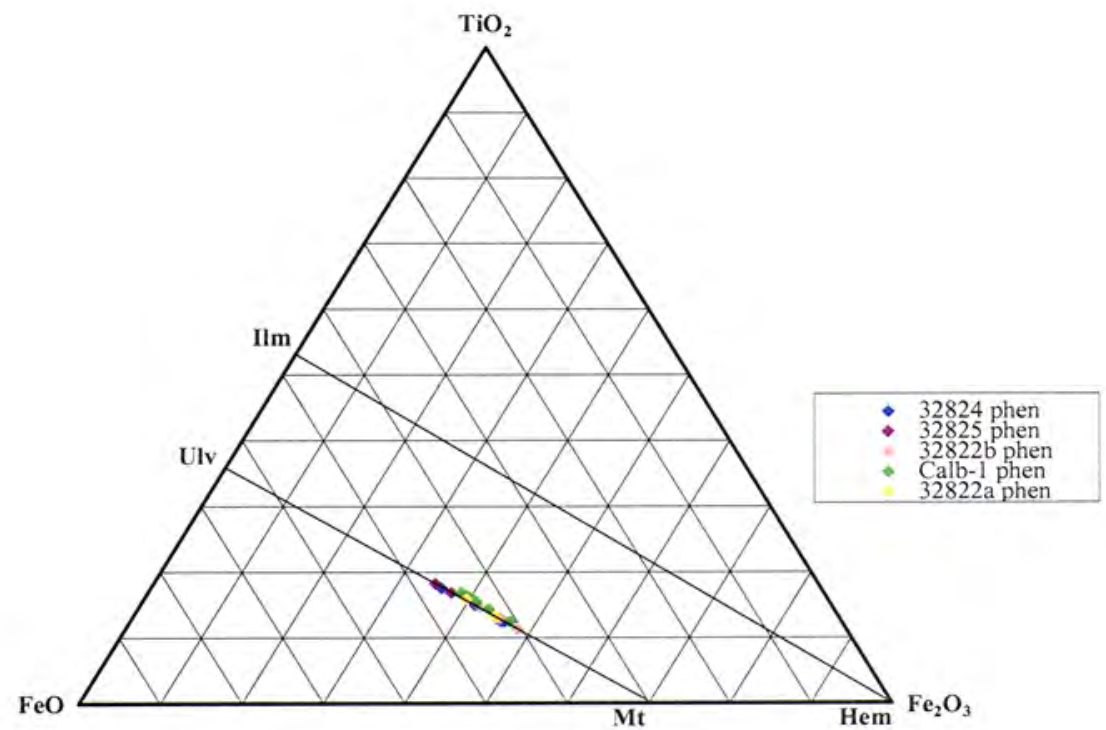

Figure 23: Ternary plot of magnetite phenocrysts in andesite. 


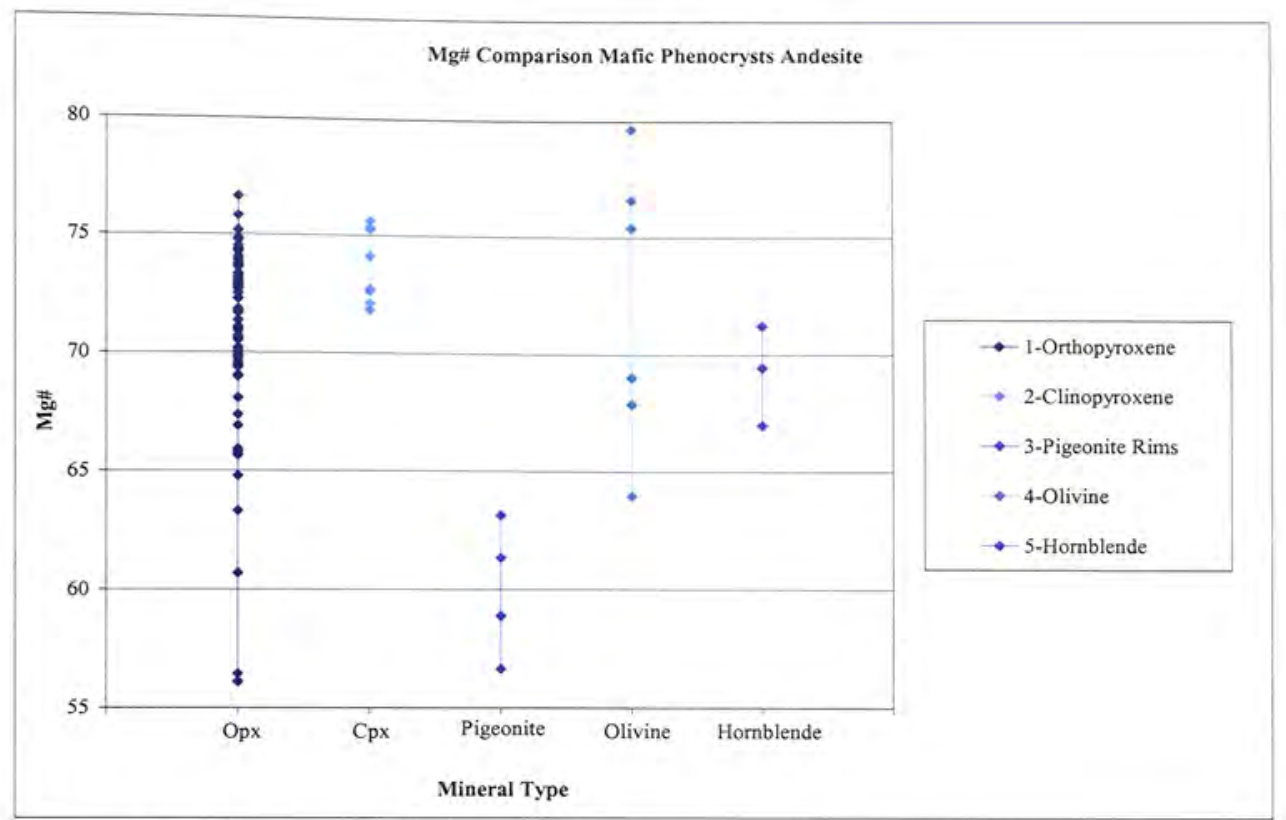

Figure 24: Andesite mafic mineral Mg\#.

Plot of mineral type versus mg-number ranges of mafic minerals (orthopyroxene, clinopyroxene, pigeonite, olivine, and hornblende) in andesite. 

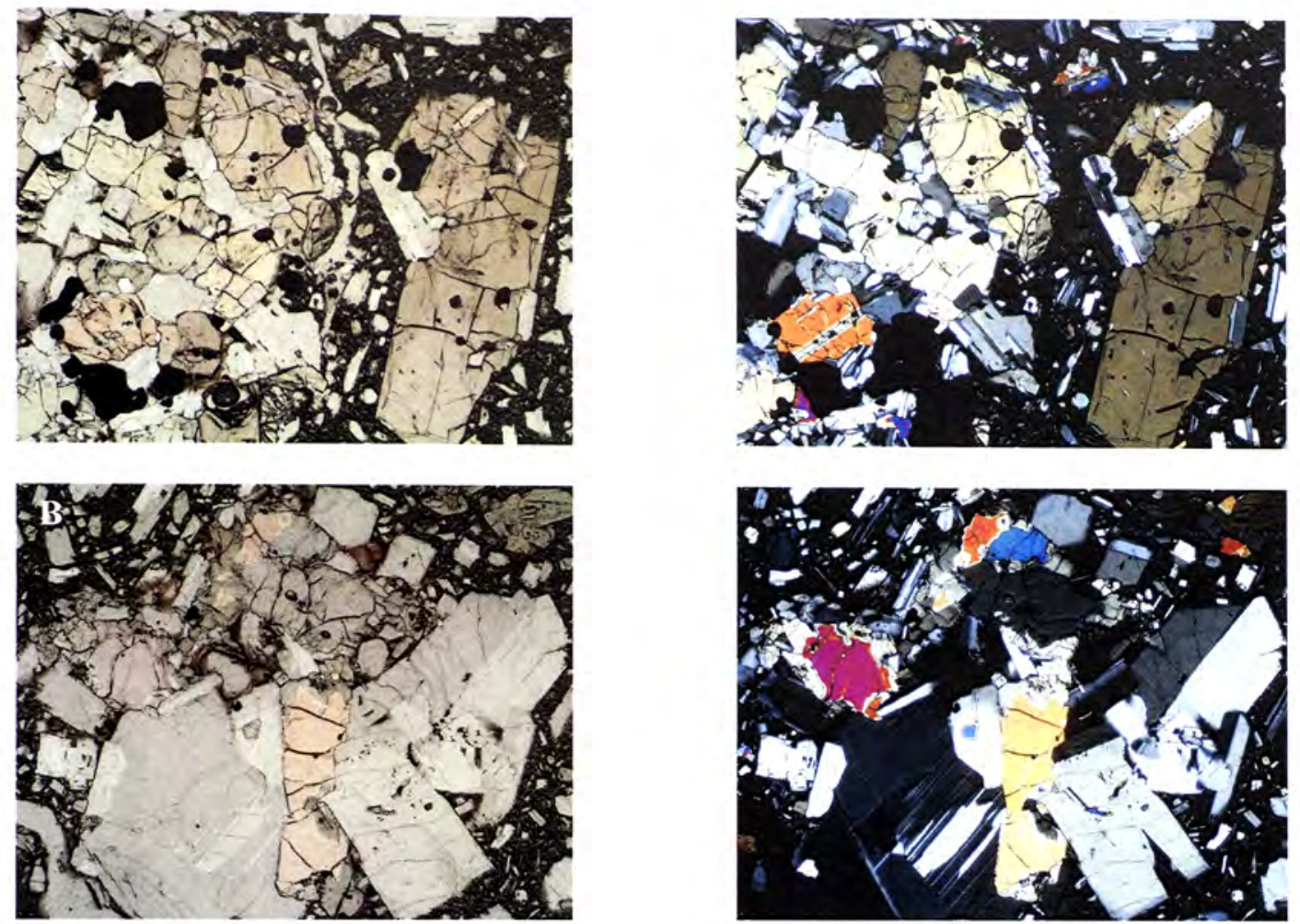

Figure 25: Photomicrographs of crystal clusters.

Photomicrographs in plane and cross polarized light of crystal clusters in lava samples. A: Type B1 crystal cluster (plagioclase, orthopyroxene, clinopyroxene, and magnetite). B: Type A2 crystal cluster (plagioclase, olivine, orthopyroxene, and magnetite) with interstitial glass. Field of view is $2.8 \mathrm{~mm}$. 


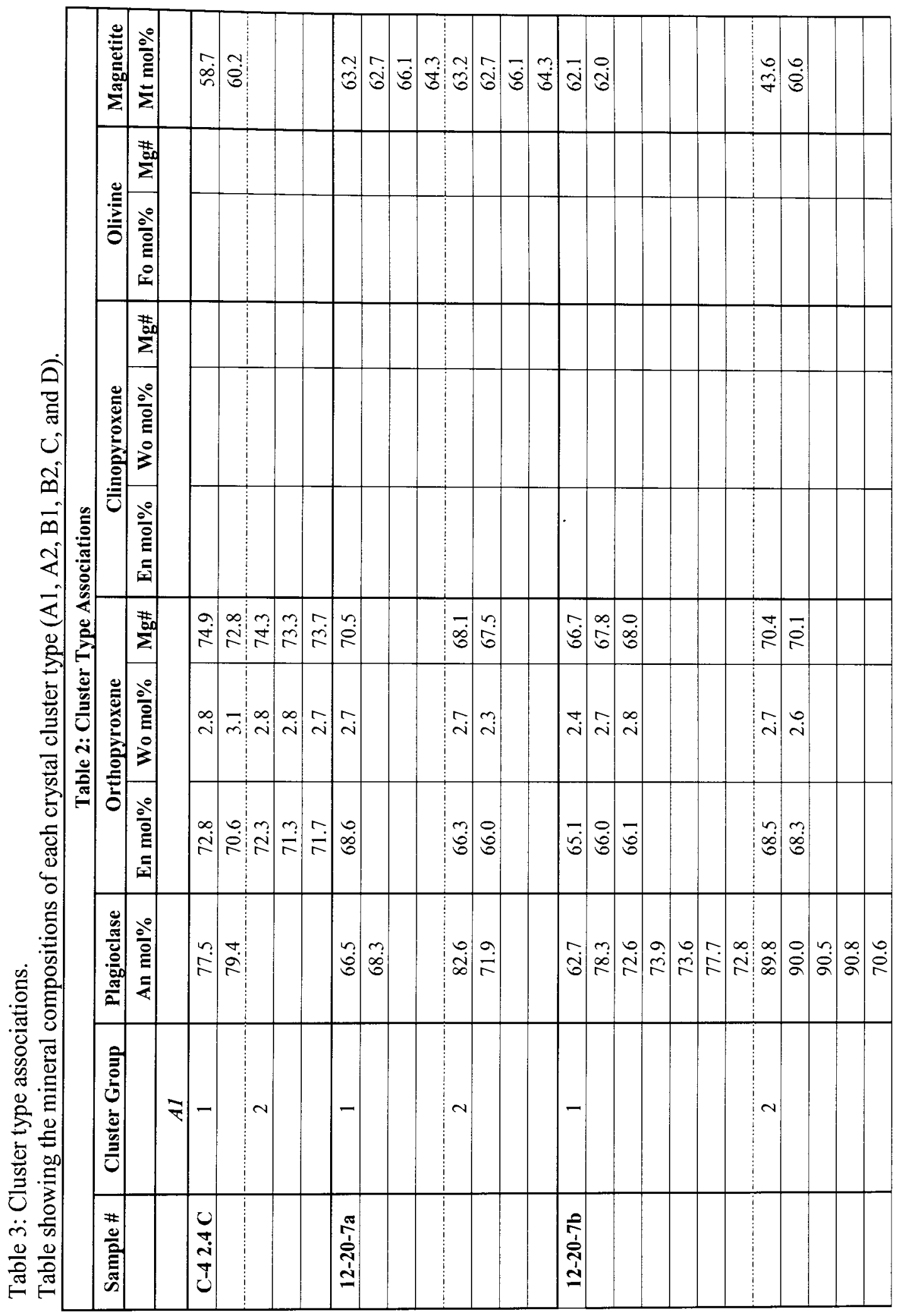




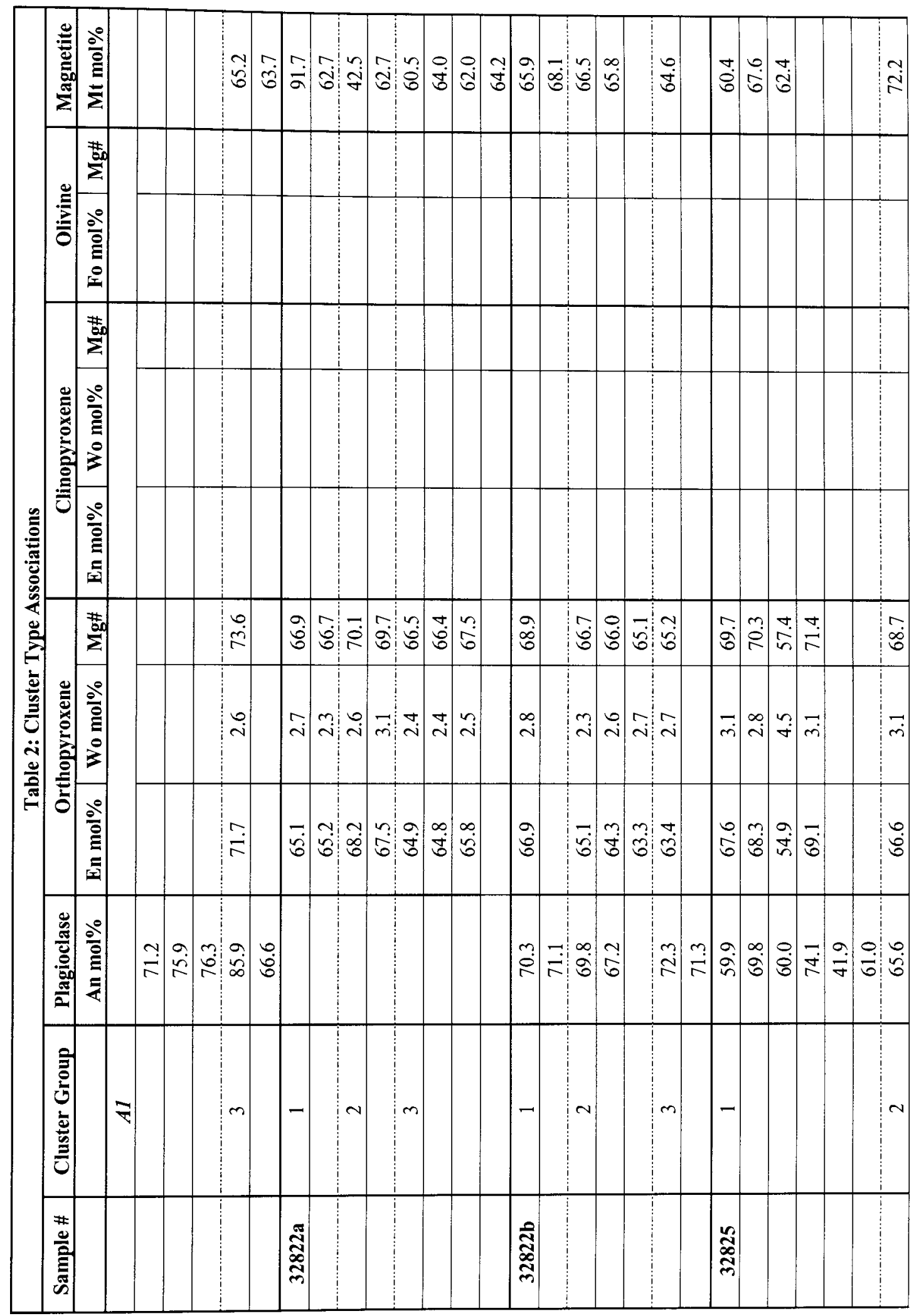




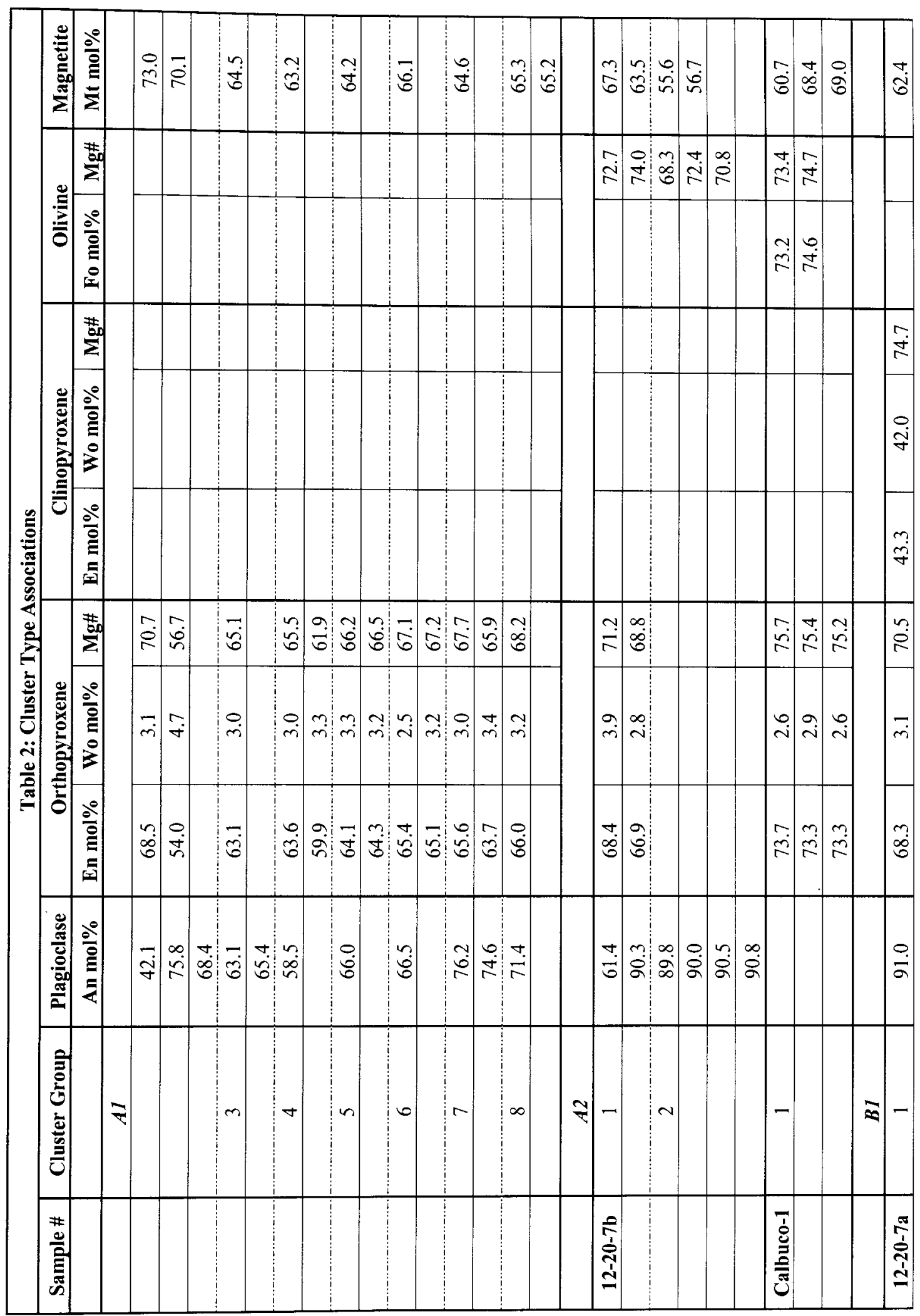




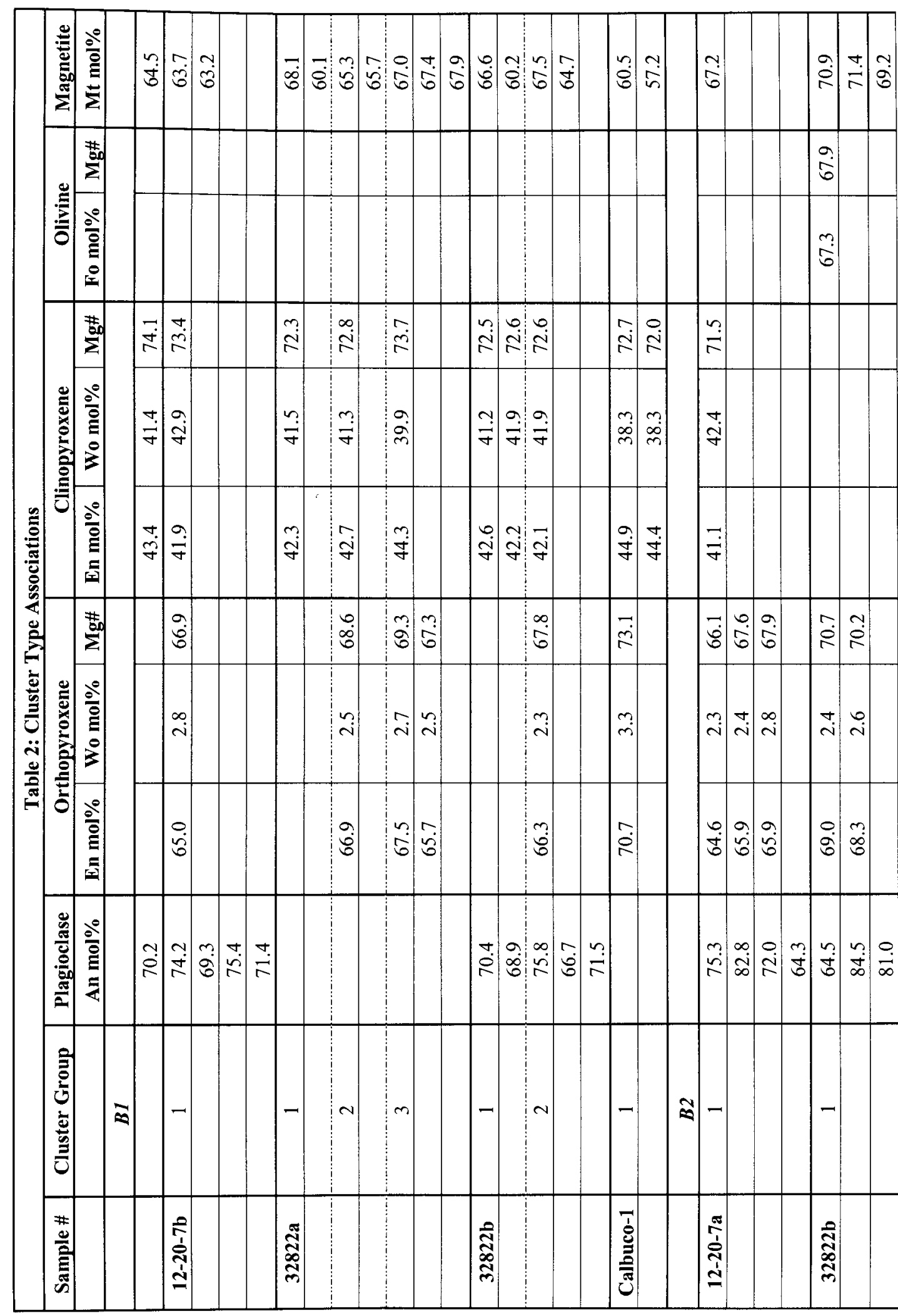




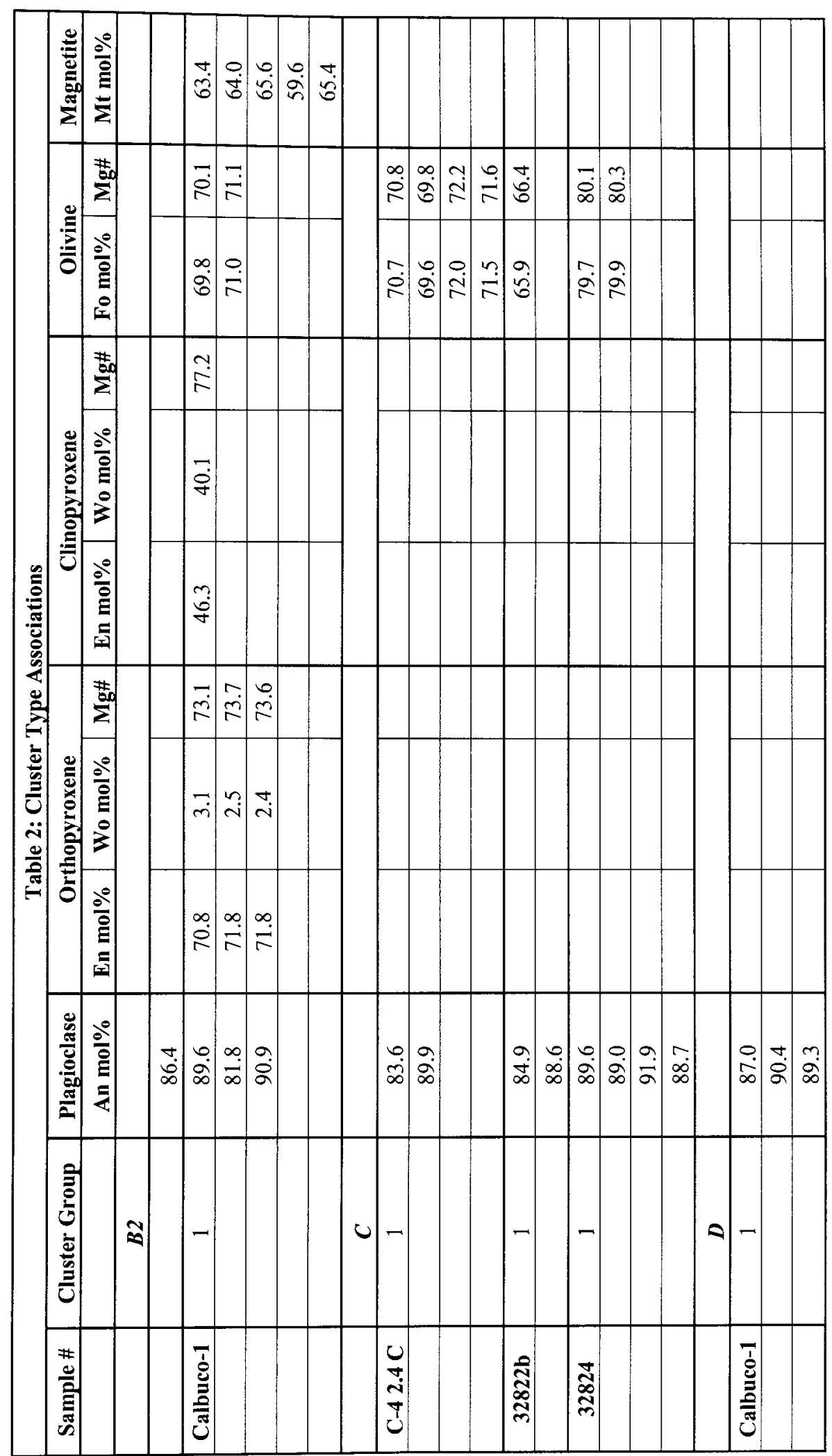




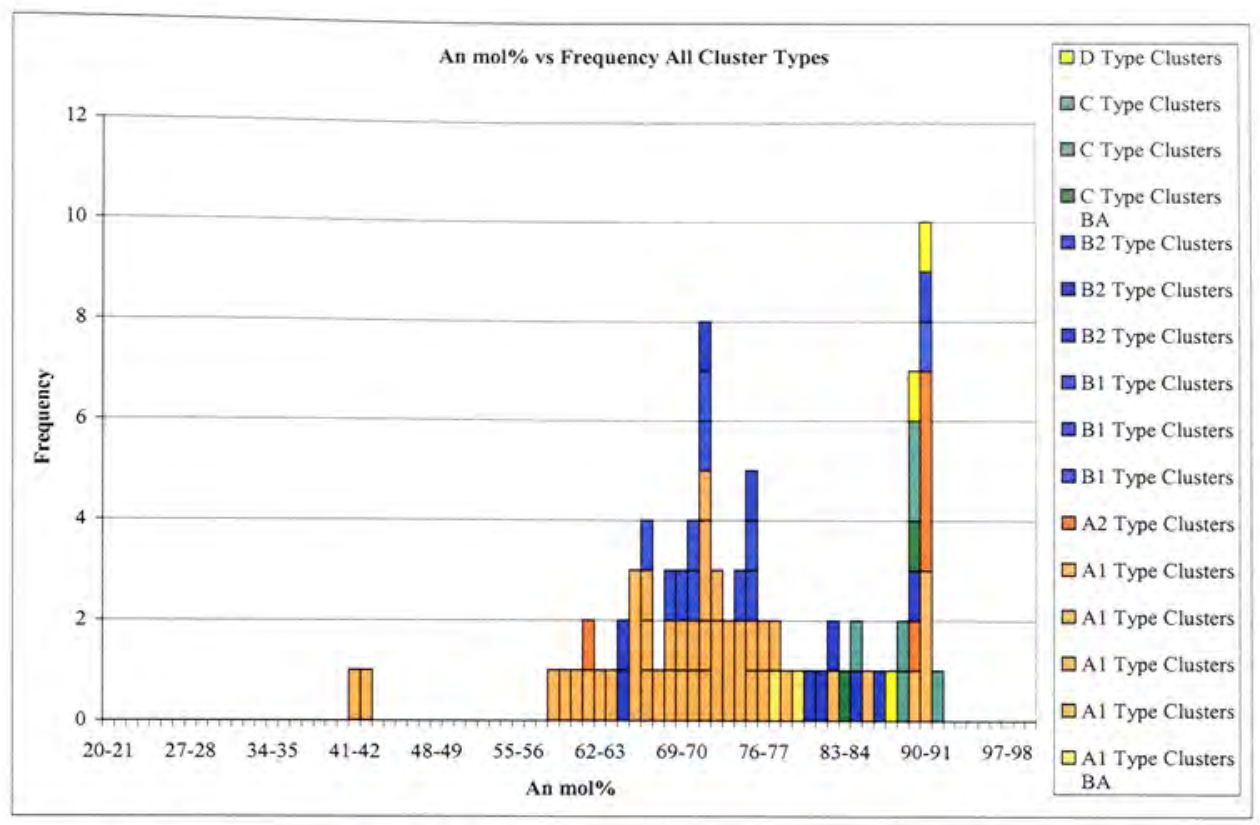

Figure 26: Histogram of An mol\% versus phenocrysts of plagioclase in type A1, A2, B1, $\mathrm{B} 2, \mathrm{C}$, and D crystal clusters.

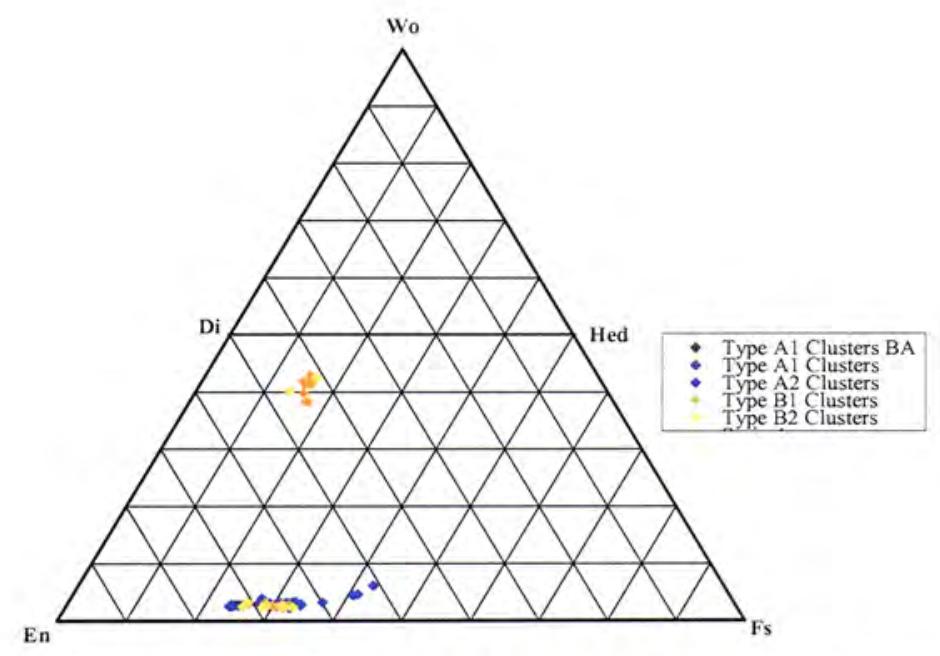

Figure 27: Ternary plot of orthopyroxene and clinopyroxene grains in type A1, A2, B1, and B2 crystal clusters. 


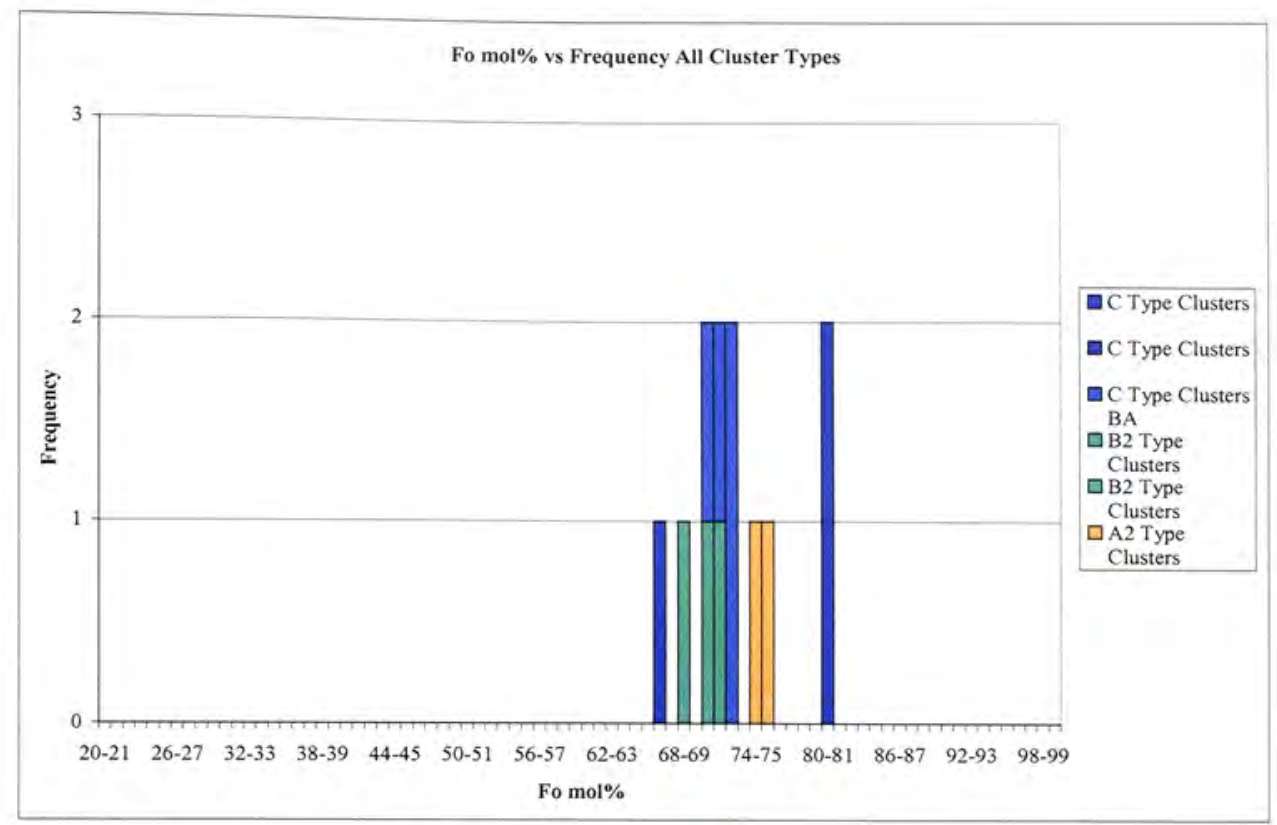

Figure 28: Histogram of Fo mol\% versus frequency of olivine grains in type A2, B2, and C.

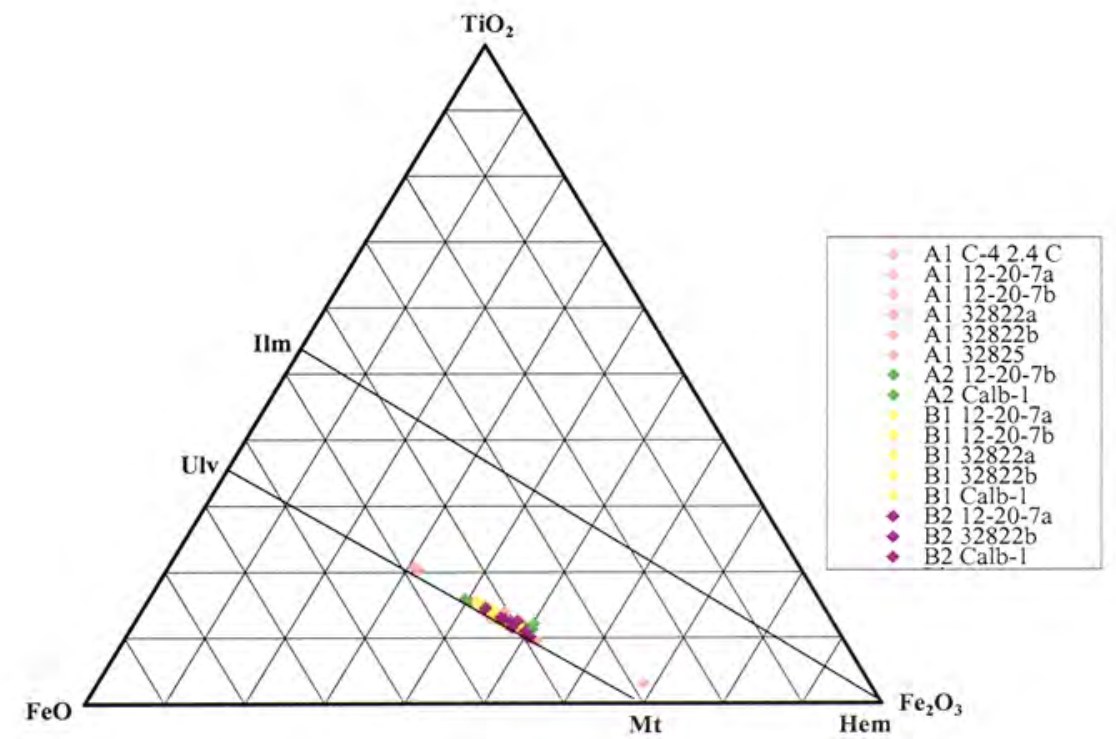

Figure 29: Ternary plot of magnetite in type A1, A2, B1, and B2 crystal clusters. 


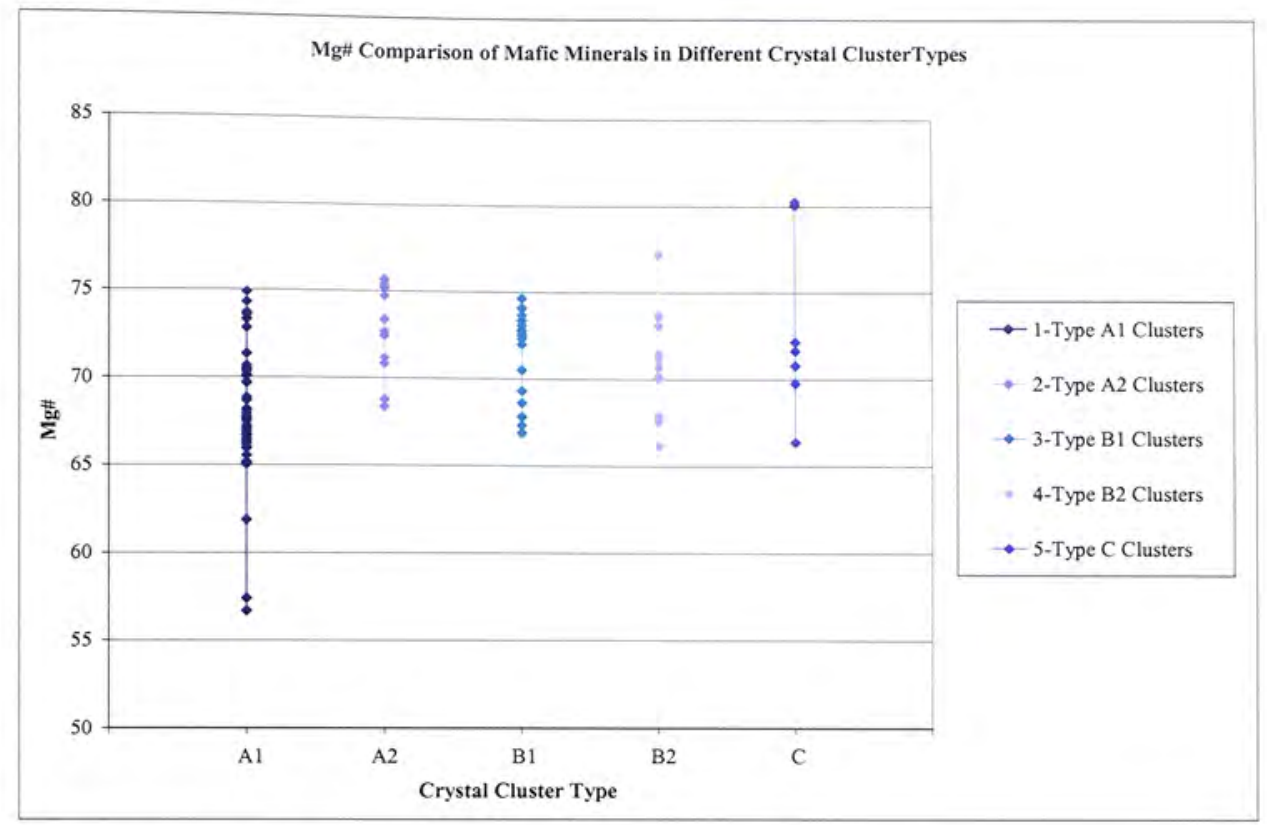

Figure 30: Crystal cluster mafic mineral Mg\#.

Plot of cluster type versus Mg-number ranges of mafic minerals in type A1, A2, B1, B2, and $\mathrm{C}$ crystal clusters.

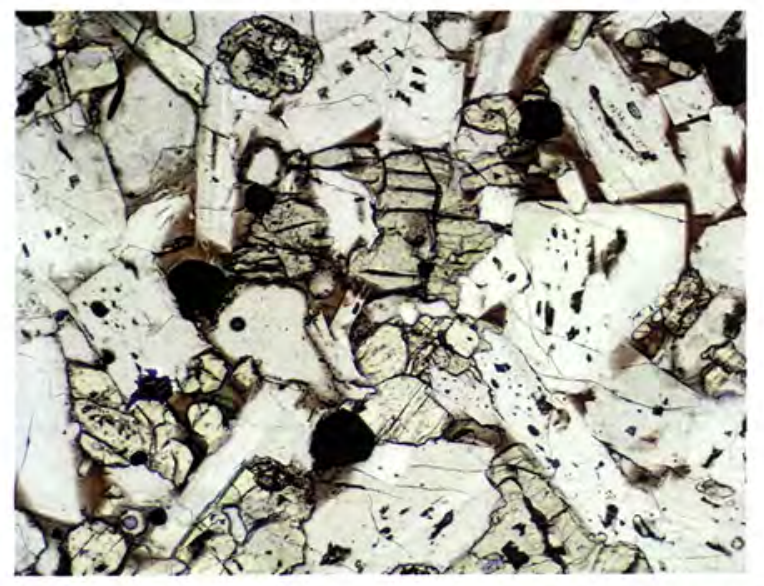

Figure 31: Photomicrograph of glass in crystal clusters.

Photomicrograph in plane polarized light of glass in crystal clusters. Field of view 1.1 $\mathrm{mm}$. 


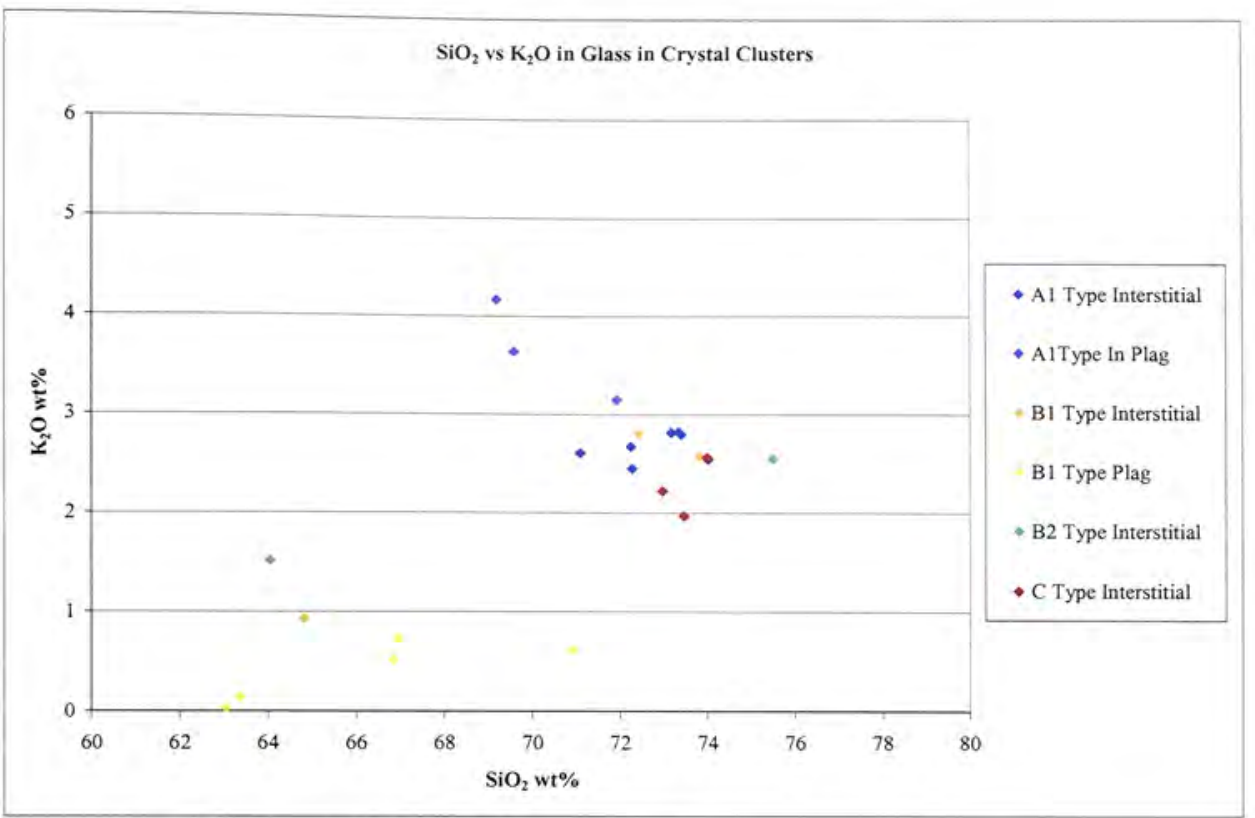

Figure 32: $\mathrm{SiO}_{2}$ versus $\mathrm{K}_{2} \mathrm{O}$ of bulk glass analyses.

Plot showing $\mathrm{SiO}_{2}$ wt \% versus $\mathrm{K}_{2} \mathrm{O}$ wt \% of interstitial glass and glass trapped in plagioclase crystals in crystal clusters. 

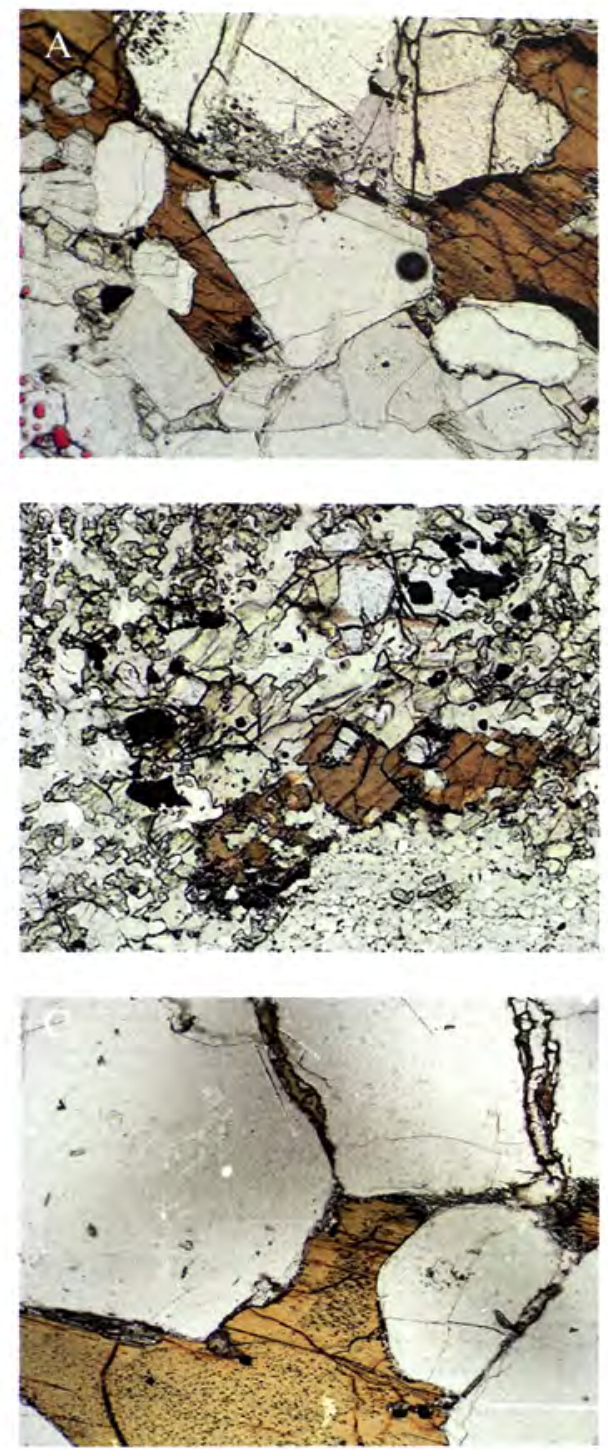
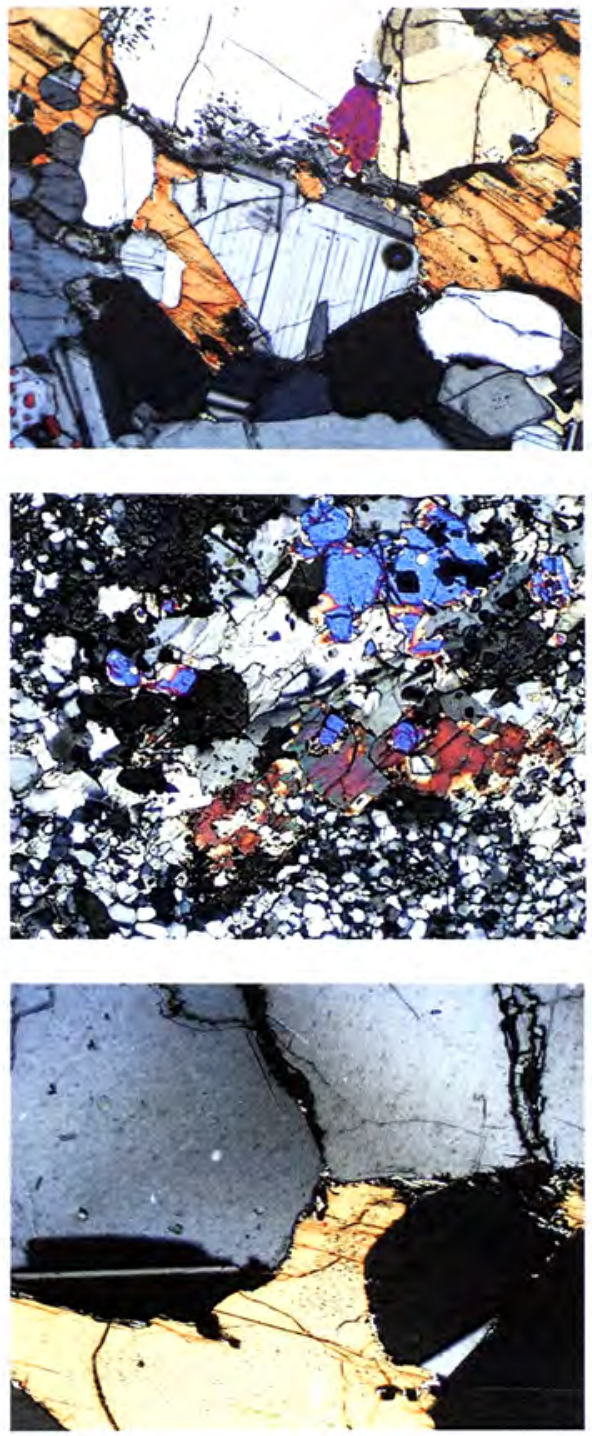

Figure 33: Photomicrographs of gabbroic xenoliths.

Photomicrographs in plane and cross polarized light of the gabbroic cumulate xenolith samples. A: sample 12-19-18, B: sample 12-20-3, C: sample 12-20-8 (interior). 


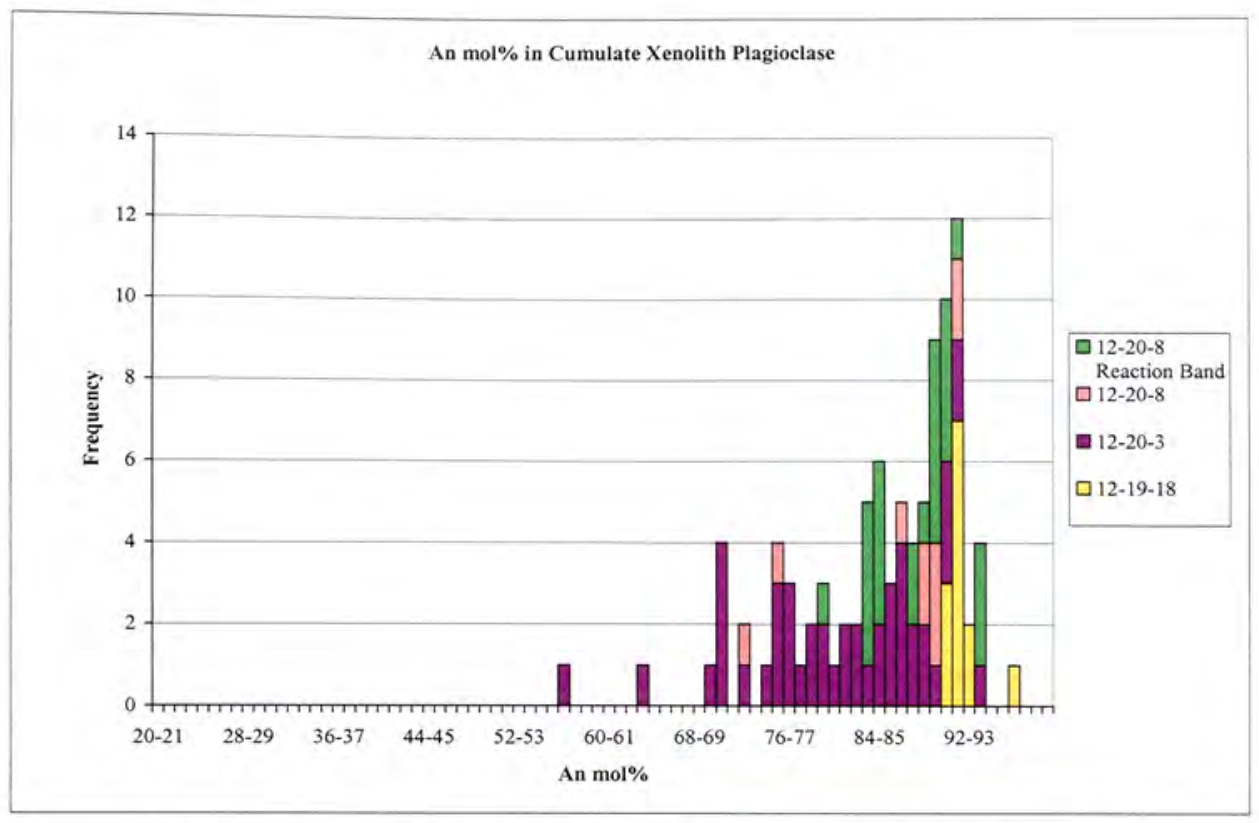

Figure 34: Histogram of An mol\% versus frequency of coarse grained plagioclase in all three gabbroic xenolith samples.

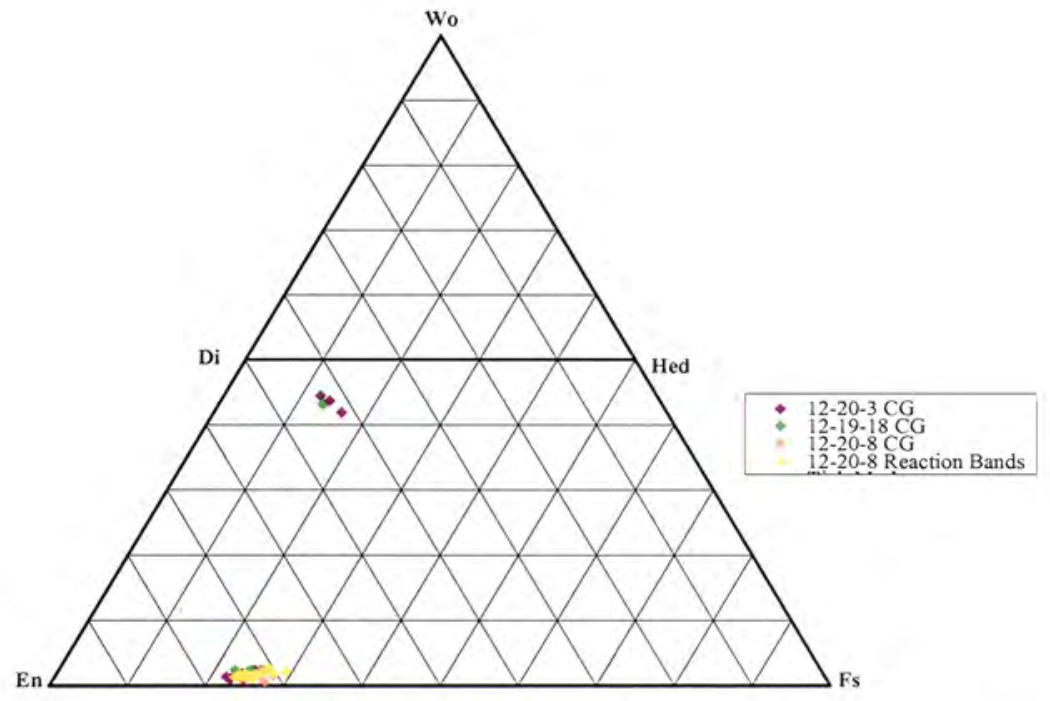

Figure 35: Ternary plot of coarse grained orthopyroxene and clinopyroxene grains in all three gabbroic xenolith samples. 


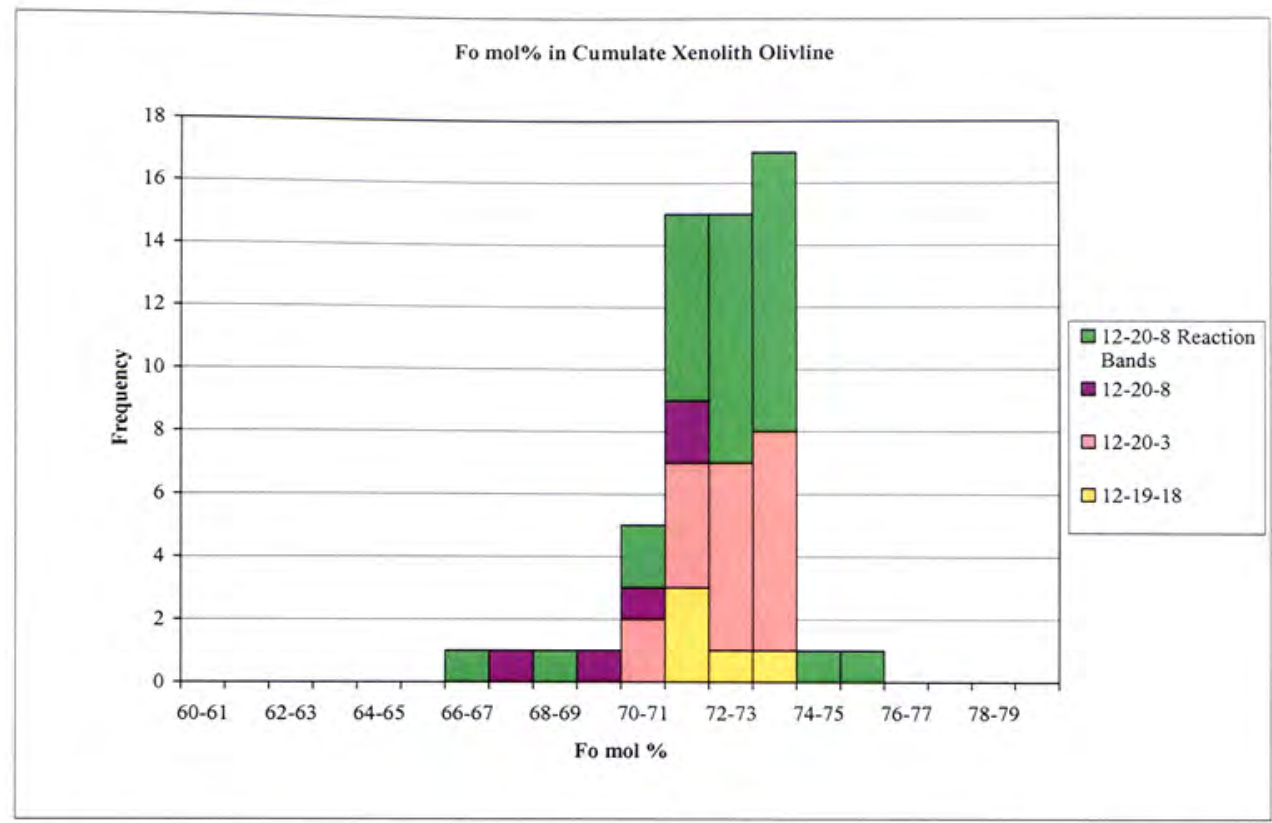

Figure 36: Histogram of Fo mol\% versus frequency of coarse grained olivine in all three gabbroic xenolith samples. 

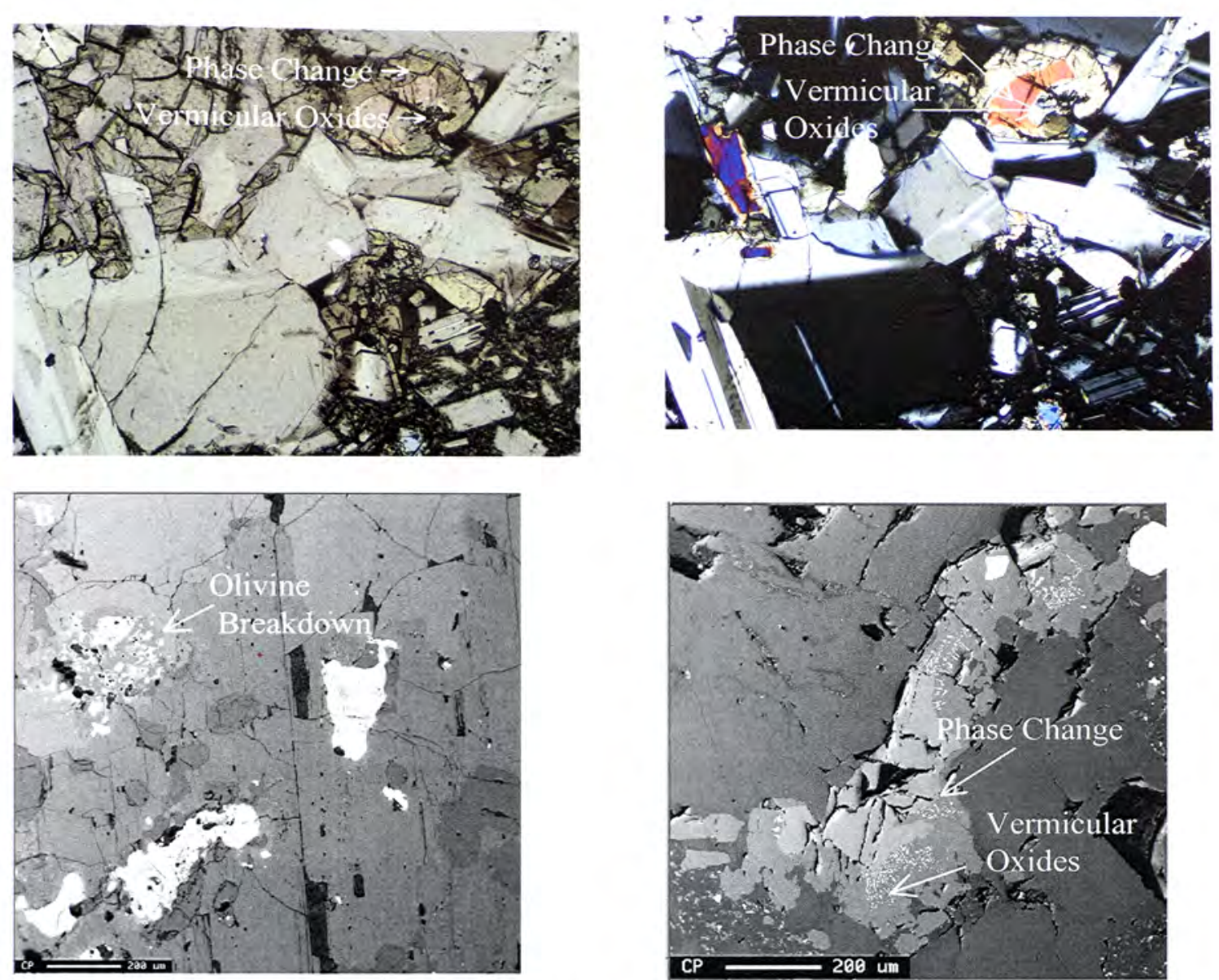

Figure 37: Images of olivine reaction textures.

A) Photomicrographs in plane and cross polarized light of olivine reaction textures in crystal cluster in lava. Field of view $1.1 \mathrm{~mm}$. B) Back scattered electron images of olivine reaction textures in cumulate xenolith samples. 


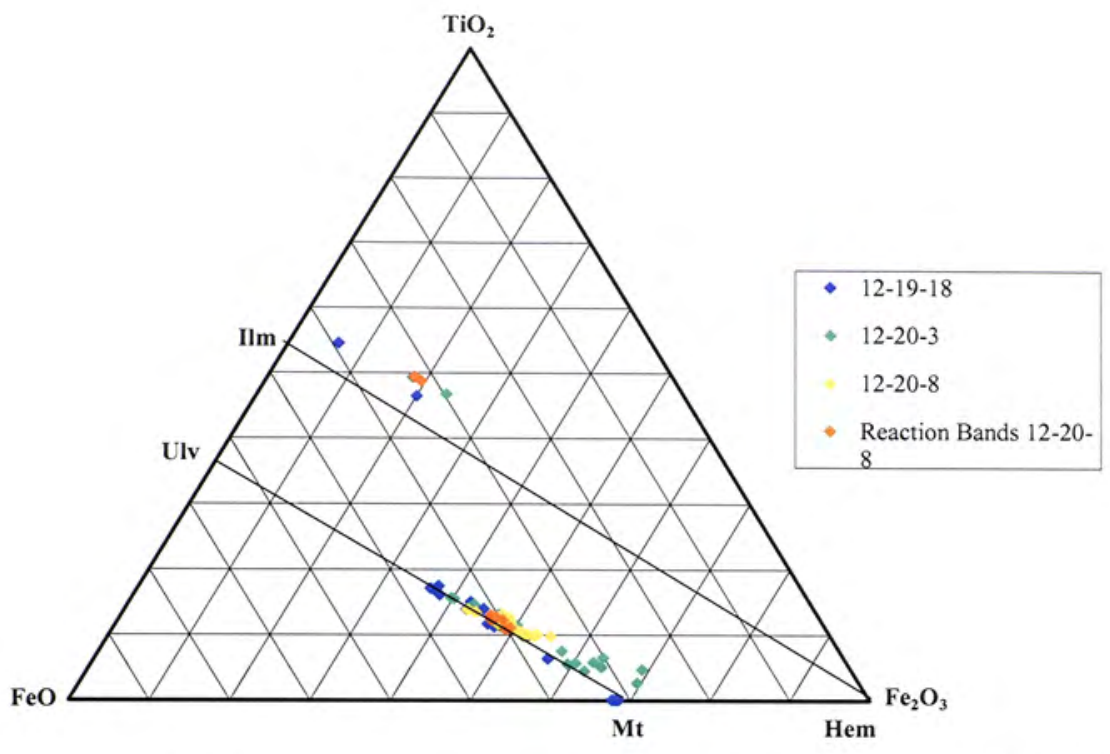

Figure 38: Ternary plot of coarse grained magnetite and ilmenite in all three gabbroic xenoliths.

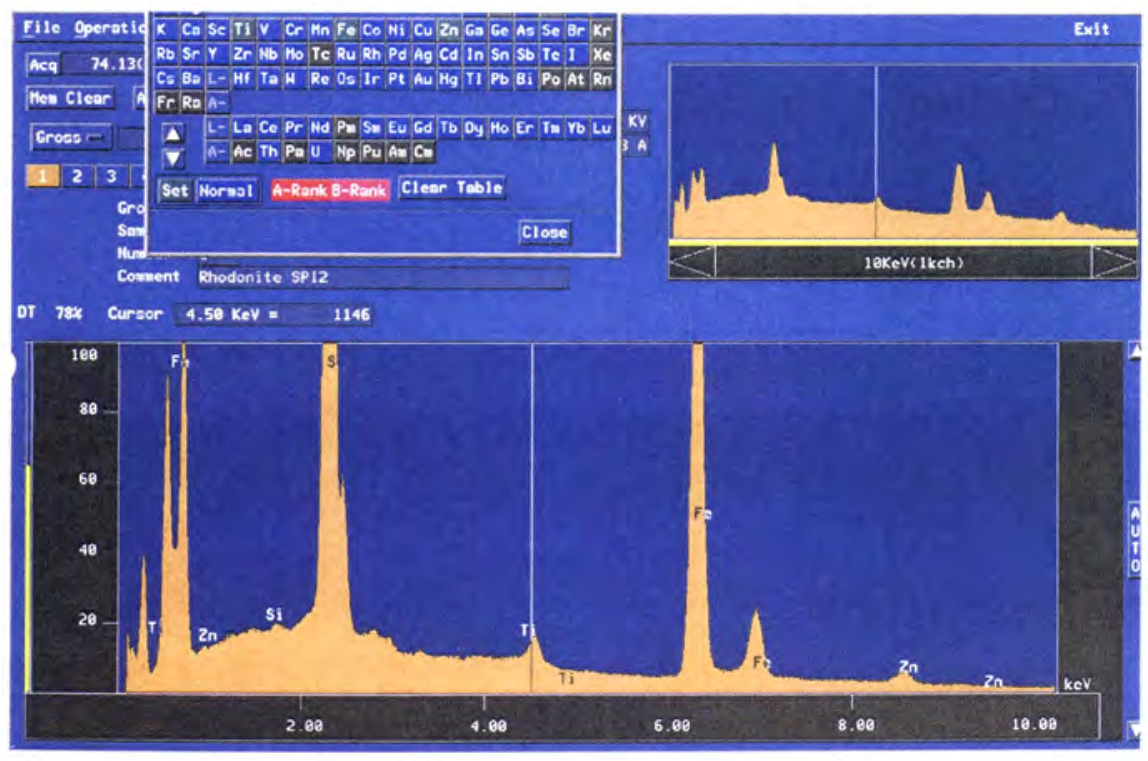

Figure 39: EDS image of Fe-sulfide mineral.

Image of EDS analysis showing relative elemental make-up of coarse grained iron sulfide in cumulate xenolith sample 12-19-18. 


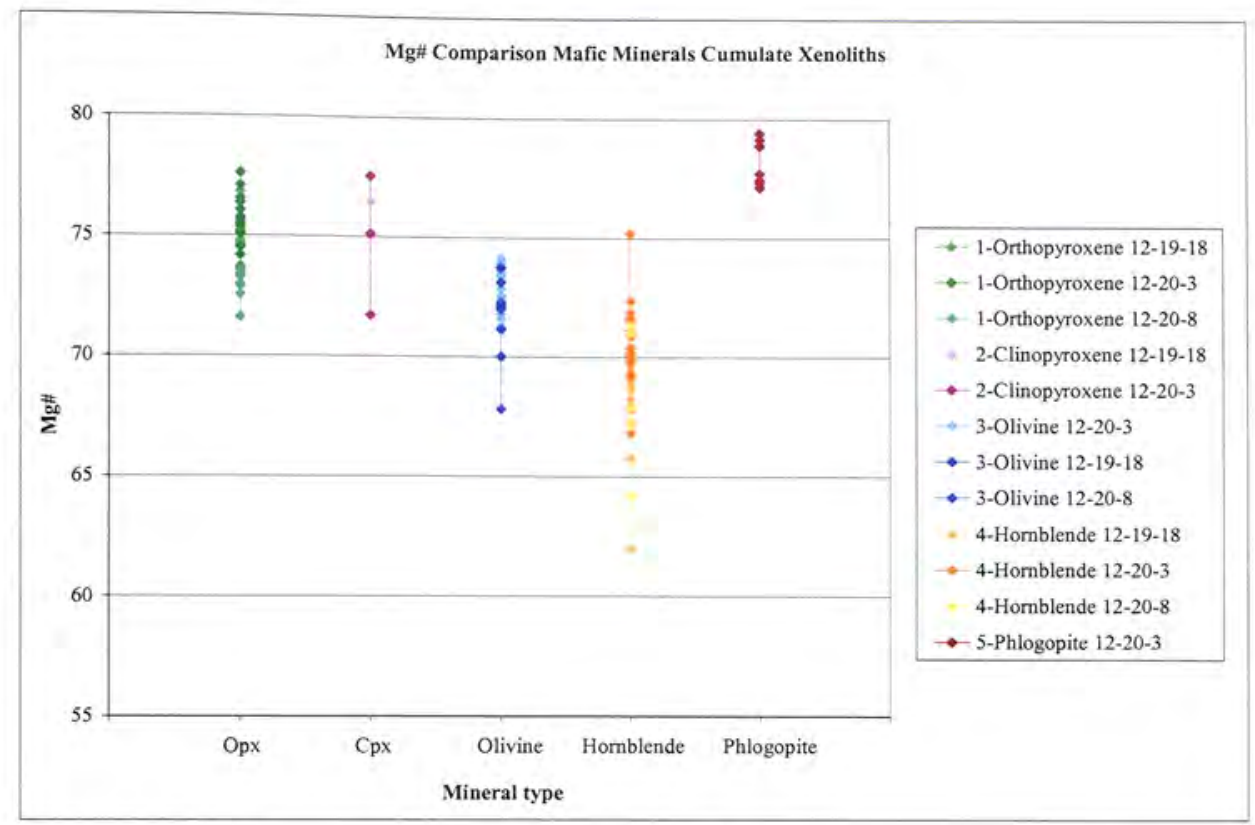

Figure 40: Gabbroic xenolith mafic mineral Mg\#.

Plot of mineral type versus $\mathrm{Mg}$-number range of coarse grained mafic minerals (orthopyroxene, clinopyroxene, olivine, hornblende, and phlogopite) in all three cumulate xenolith samples.
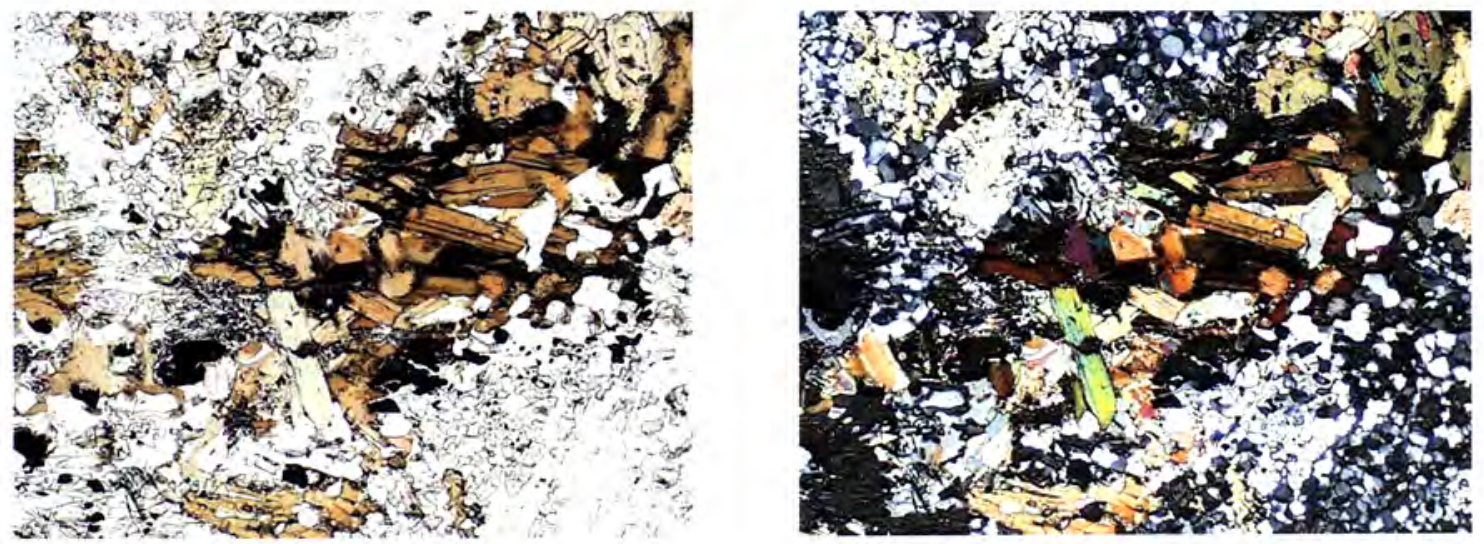

Figure 41: Photomicrographs of phlogopite.

Photomicrographs in plane and cross polarized light of phlogopite crystals in gabbroic xenolith sample 12-20-3. Field of view $2.8 \mathrm{~mm}$. 

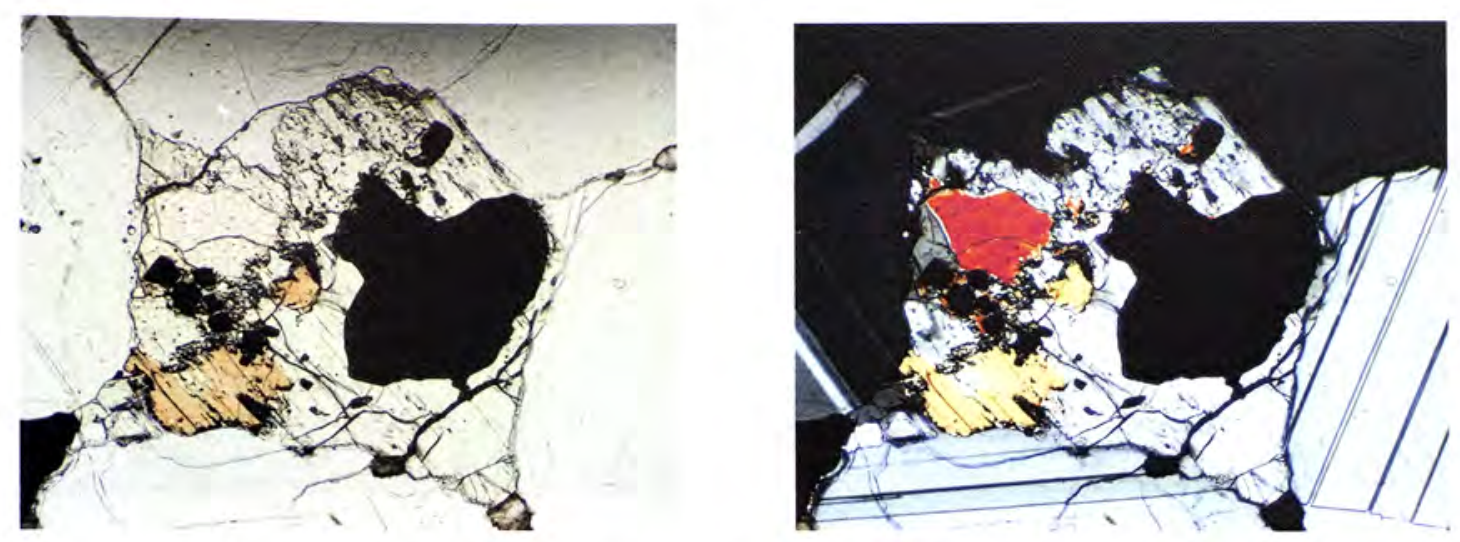

Figure 42: Photomicrographs of interstitial breakdown pockets.

Photomicrographs in plane and cross polarized light of breakdown pockets, containing olivine, orthopyroxene, magnetite, and hornblende, between coarse grained plagioclase in gabbroic xenolith 12-20-8. Field of view $2.8 \mathrm{~mm}$.
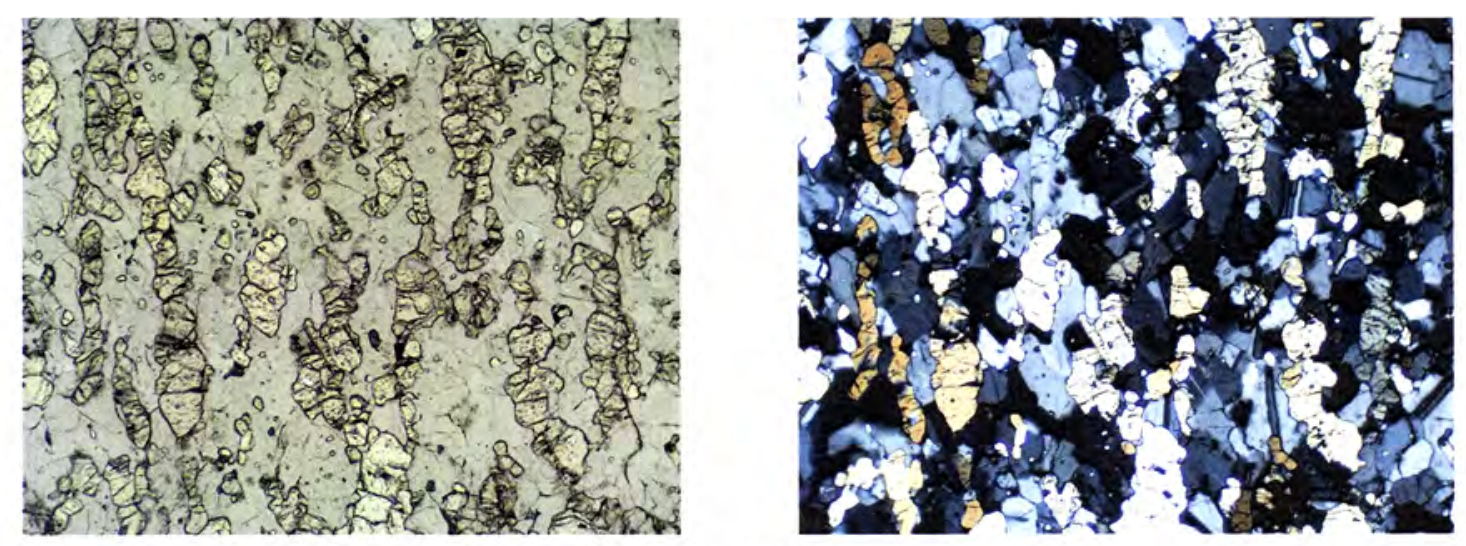

Figure 43: Photomicrographs of reaction bands.

Photomicrographs in plane and cross polarized light of reaction bands in sample 12-20-8. Field of view $2.8 \mathrm{~mm}$. 

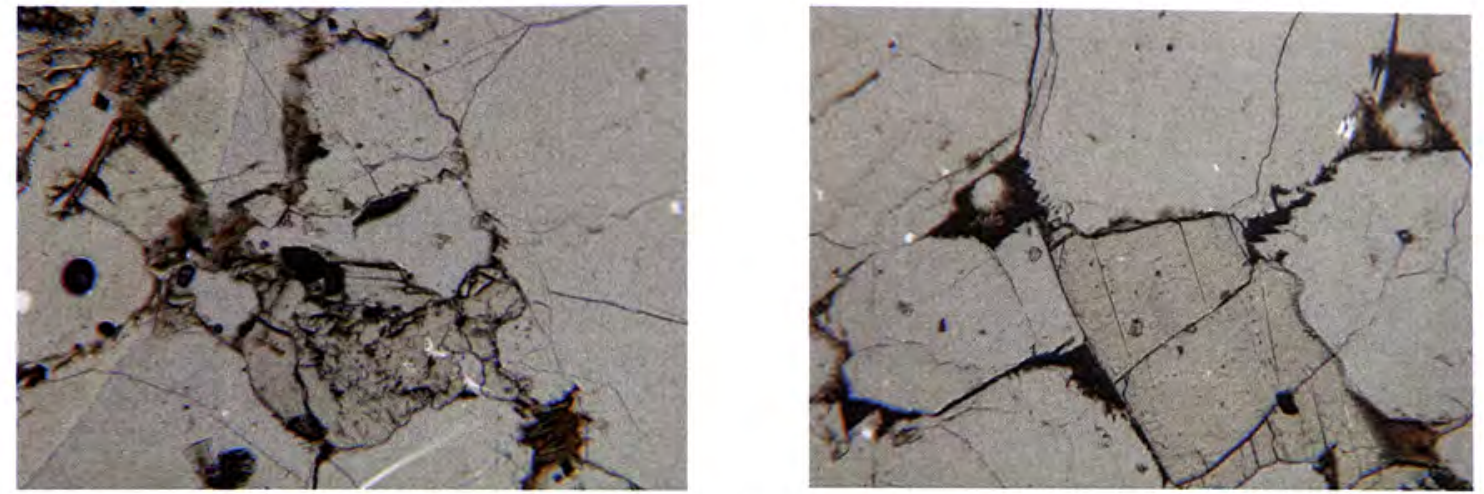

Figure 44: Photomicrographs of glass in gabbroic xenoliths.

Photomicrographs in plane polarized light showing the interstitial glass in cumulate xenolith samples. Field of view $1.1 \mathrm{~mm}$.

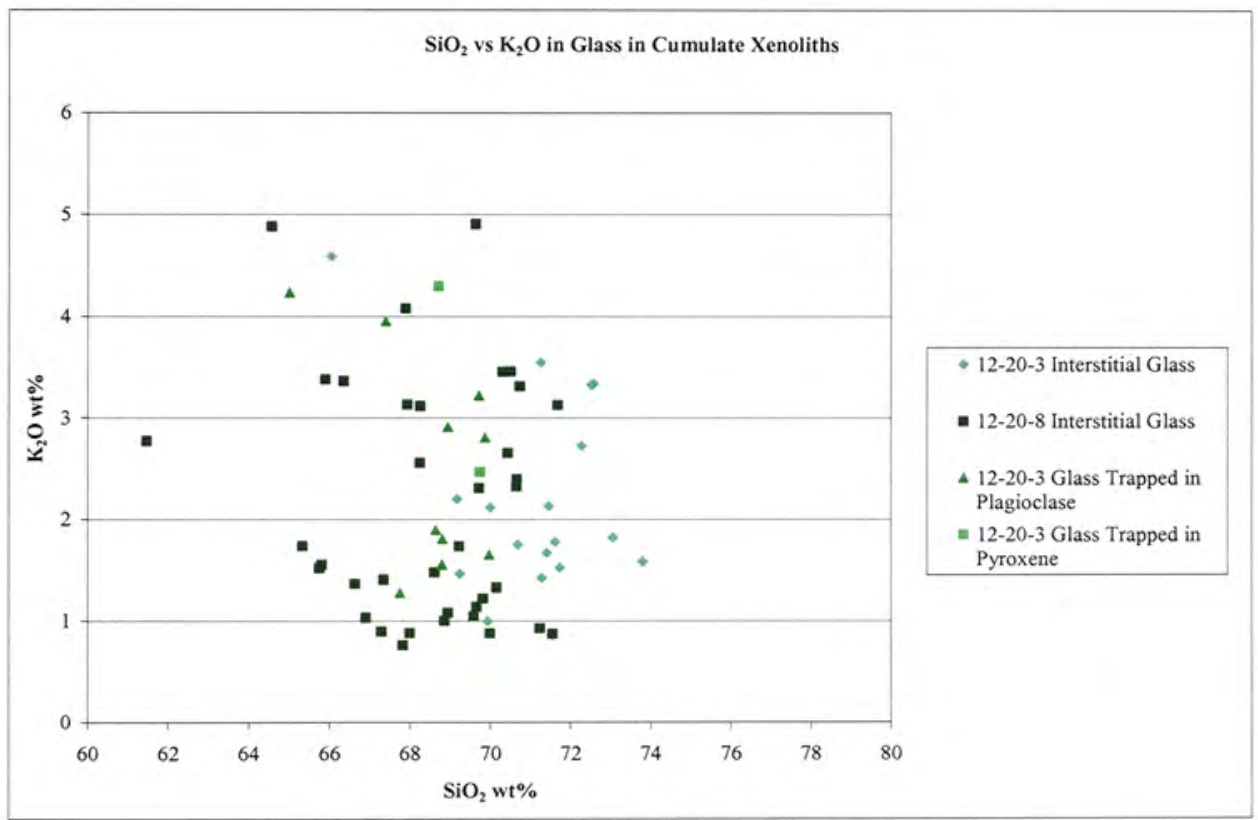

Figure 45: $\mathrm{SiO}_{2}$ versus $\mathrm{K}_{2} \mathrm{O}$ of glass in gabbroic xenoliths.

Plot of $\mathrm{SiO}_{2}$ wt $\%$ versus $\mathrm{K}_{2} \mathrm{O}$ wt $\%$ of interstitial glass and glass trapped in coarse grained plagioclase and pyroxene in gabbroic xenolith samples $12-20-3$ and 12-20-8. Glass analyses have been screened for crystal structure, however outlying data points may be overlap, due to use of a defocused beam on the electron microprobe, between the glass and host crystals or post entrapment crystals. 


\section{Chapter 5. Hornblende}

\subsection{Introduction}

Results of López-Escobar et al. (1995), Hickey-Vargas et al. (1995), and McKelvey and Hickey-Vargas (2004) have shown that hornblende is present in both the cumulate gabbronorite xenoliths as coarse grains and in the andesite lava as phenocrysts. The presence of hornblende, a hydrous mineral, among the eruptive products of Calbuco is evidence for the involvement of water in Calbuco's magmatic processes. There have been numerous previous reports of hornblende associated with arc volcanism (examples include Cawthorn and O'Hara, 1976; Yagi and Takeshita, 1987; Anderson, 1980; Foden and Green, 1992). Experimental studies of basalts (Yagi and Takeshita, 1987; Foden and Green, 1992; Green and Ringwood, 1967; Cawthorn and O'Hara, 1976) have shown that that hornblende fractionation is an important factor in the genesis of calc-alkaline andesites (Yagi and Takeshita, 1987). Hornblende is a silica-poor mineral (pargasitic hornblende $<40 \mathrm{wt} \% \mathrm{SiO}_{2}$ ) and as it crystallizes it drives the residual magma toward higher $\mathrm{SiO}_{2}$ contents (Foden and Green, 1992) than does the crystallization of other ferromagnesian minerals, such as pyroxenes.

This chapter is a discussion of hornblende at Calbuco, including the chemistry and texture of both hornblende phenocrysts and coarse grained hornblende in gabbroic xenoliths, a comparison of the two hornblende populations, and a description of the texture, mineral assemblage, and chemistry of hornblende breakdown reaction products. It also details stability of the hornblende crystals and the Cr contents of the phlogopite and both hornblende populations compared with the $\mathrm{Cr}$ contents of the respective mineral phases in Volcán San Pedro andesite. 


\subsection{Hornblende Phenocrysts in the Lava}

Hornblende phenocrysts are found in the andesitic lavas, but not in the basaltic andesite. The observed phenocrysts are breaking down and are therefore apparently unstable at the upper magma chamber conditions of Calbuco. Hornblende analysis was done on one partially reacted crystal remaining in the center of a hornblende pseudomorph (Figure 46). Two similar hornblende pseudomorphs were found in a second thick section sample with no hornblende remaining. The reaction products of these three pseudomorphs were analyzed (complete electron microprobe data of all hornblende and associated breakdown reaction products can be found in appendix C).

\section{2a Textural Description and Mineral Chemistry}

Amphibole phenocrysts in the lava are pargasite (Figure 47), which is a calcic hornblende, $\mathrm{NaCa}_{2}\left(\mathrm{Mg}_{4} \mathrm{Al}\right) \mathrm{Si}_{6} \mathrm{Al}_{2} \mathrm{O}_{22}(\mathrm{OH})_{2}$, according to the method detailed in Leake et al. (1997). López-Escobar et al. (1995) reported the presence of edenite phenocrysts, $\mathrm{NaCa}_{2} \mathrm{Mg}_{5} \mathrm{Si}_{7} \mathrm{AlO}_{22}(\mathrm{OH})_{2}$, which have slightly higher $\mathrm{Si}$ and $\mathrm{Mg}$ and lower $\mathrm{Al}$ than pargasite. Three different types of breakdown products are observed (Figure 48), all of which typically occur as pseudomorphs of hornblende crystals with a detectable rim. The first type (Figure 48A, B) is black and "muddy looking" and consists of metamorphic textured microcrystalline mineral grains. In this type the original hornblende crystal is either completely or nearly broken down. The second type (Figure 48C, D) consists of medium grained, unzoned crystals with patches of the same black microcrystalline material as in the first type. No remaining hornblende has been found associated with the second type of reaction product. These two types of breakdown products are similar to the "black type" and "gabbroic type" reaction products described by Garcia and Jacobson 
(1979) in lavas from the Cascade Range respectively, which may coexist in the same sample. The third type of breakdown products are reaction rims on the hornblende phenocrysts (Figure 48E, F). Two different types of rims are found, the first type is black and microcrystalline and the second is lighter in color and medium to fine grained. The light-colored, medium grained rim is made up of plagioclase and pyroxene with rare oxide minerals (presumably magnetite) and has only been found on one hornblende phenocryst. This rim type is similar to the reaction rims described by Devine et al. (1998a, b) and Rutherford and Devine (2003) in lavas from Soufrière Hills. The black microcrystalline rims, also described by Devine et al. (1998b) and Rutherford and Devine (2003) as opacite rims, are similar to the "black type" reaction products described above. Electron microprobe analyses have been done of the "black type" breakdown products but not the light-colored reaction rims or "gabbroic type" reaction products due to polished section quality (see chapter 3 for details).

\section{$5.2 b$ Breakdown Chemistry}

Products of hornblende phenocryst breakdown (Table 4, Table 5) include microcrystalline grains of plagioclase, olivine, magnetite, and pyroxene, all of which range in size up to approximately 5 microns. Plagioclase compositions (Figure 49) range from oligoclase to labradorite $\left(\mathrm{An}_{27-61}\right)$. Pyroxene varieties include orthopyroxene, lowCa clinopyroxene (pigeonite), and clinopyroxene (augite); with clinopyroxene the most abundant of the three. The compositions of the different pyroxene varieties (Figure 50) are orthopyroxene, $\mathrm{En}_{63}, \mathrm{Wo}_{3}$, clinopyroxene $\mathrm{En}_{43-48}, \mathrm{Wo}_{34-42}$, and pigeonite, $\mathrm{En}_{56-62}, \mathrm{Wo}_{9}$ -

15. Compositionally, olivine ranges from $\mathrm{Fo}_{66-70}$ (Figure 51). Magnetite grains were recalculated following the procedure outlined in Droop (1987), and compositionally 
range from to $\mathrm{Mt}_{54-64}$ (Figure 52). Mg-numbers for the different mafic phases in the hornblende breakdown products are shown on Figure 53. The olivine and pigeonite have a bimodal distribution of Mg-number ranges. The less magnesian end of the olivine range overlaps the compositions of orthopyroxene and hornblende, however, clinopyroxene is more magnesian than this range. Only two pigeonite grains were analyzed, however the more magnesian of the two overlaps with the composition of the clinopyroxene. The more magnesian olivine and less magnesian pigeonite compositions do not coincide with any other compositions.

\subsection{Hornblende Crystals in the Cumulate Xenoliths}

Hornblende is a common phase in gabbroic xenoliths in arc related lava (Yagi and Takeshita, 1987; Costa et al., 2002). These hornblende-bearing gabbros have been interpreted to reflect differentiation processes, specifically crystal fractionation (Costa et al., 2002), inside many volcanic systems including Calbuco (Hickey-Vargas et al., 1995). Yagi and Takeshita (1987) suggested that fractionation of approximately $40 \%$ of a hornblende gabbroic assemblage from hydrous, high-alumina basalt could produce calcalkaline andesitic magma. Compositions of the gabbronorite xenoliths from Calbuco are consistent with fractionation of this assemblage from a moderate-alumina basaltic andesite (see chapter 2 for discussion) (López-Escobar et al., 1995).

\section{3a Textural Description and Mineral Chemistry}

Coarse grained amphibole in three cumulate xenolith samples was recalculated using the same procedure as the phenocryst recalculation (Leake et al., 1997). As a result of this recalculation, there are two types of calcic hornblende in the cumulate xenoliths, pargasite and edenite (complete electron microprobe data of all hornblende and 
associated breakdown reaction products can be found in appendix C). The pargasite is similar in composition to the pargasitic hornblende phenocrysts in the lava (Figure 54). Hornblende in the cumulate xenoliths is also unstable and breaking down, although the individual gabbroic samples exhibit varying degrees of this breakdown reaction from slight to extreme. Hornblende in sample $12-19-18$ is one grain poikilitically enclosing all of the other grains in the gabbro and is only slightly broken down (Figure 55A). Samples 12-20-3 and 12-20-8 have individual hornblende grains with stability ranging from slightly reacted (Figure 55B) to extremely broken down (Figure 55C). Similar to hornblende phenocryst breakdown above, products of this reaction form black microcrystalline patches around and throughout the crystals, consistent with "black type" breakdown products from Garcia and Jacobson (1979), which are also collections of mineral grains 5 microns or less in size (Figure 56).

\section{$5.3 b$ Breakdown Chemistry}

Mineral breakdown products of the hornblende (Table 4, Table 5) in the three cumulate xenoliths are the same as products of the phenocryst breakdown (plagioclase, olivine, clinopyroxene, low-Ca clinopyroxene, orthopyroxene, and magnetite with accessory ilmenite). Overall, the composition of the reaction-produced plagioclase overlaps in all three xenoliths; the only variation being in the $\mathrm{Na}$ content of the most sodic grain found in each sample. Compositionally, plagioclase in sample 12-19-18 ranges from andesine to bytownite $\left(\mathrm{An}_{45-79}\right)$, plagioclase in sample 12-20-3 from oligoclase to bytownite $\left(\mathrm{An}_{26-83}\right)$, and plagioclase in sample $12-20-8$ from albite to bytownite $\left(\mathrm{An}_{7-81}\right)$. The majority of these grains range from oligoclase to labradorite $\left(\mathrm{An}_{26-66}\right)$, overlapping the compositional range of $\mathrm{An}_{27-61}$ for the plagioclase in the 
hornblende phenocryst breakdown (Figure 57). Olivine is only found as a hornblende reaction product in two of the three xenoliths, samples 12-19-18 and 12-20-3. Olivine in sample $12-19-18$ is $\mathrm{Fo}_{65-68}$, in sample $12-20-3$ is $\mathrm{Fo}_{67-69}$ and $\mathrm{Fo}_{80-85}$, with no grains existing between the two ranges (Figure 59). Magnetite and ilmenite (Figure 60) were recalculated following the same procedure as for the phenocryst breakdown products. Compositionally, magnetite ranges from $\mathrm{Mt}_{44-100}$, with one outlying grain of $\mathrm{Mt}_{20}$ in sample 12-19-18, from $\mathrm{Mt}_{4-13}$ and $\mathrm{Mt}_{48-82}$, with no compositions found in between in sample 12-20-3, and $\mathrm{Mt}_{23-54}$ in sample 12-20-8. Only two ilmenite grains were analyzed in sample 12-20-3 which range from $\operatorname{Ilm}_{56-61}$. Orthopyroxene, clinopyroxene, and low-Ca clinopyroxene (Figure 58) occur in the reaction products, and, similar to the phenocryst breakdown, clinopyroxene is the most abundant. The orthopyroxene formed in the hornblende reaction in all three samples ranges compositionally from $\mathrm{En}_{71-72}, \mathrm{Wo}_{3}$ in sample $12-19-18, \mathrm{En}_{73-75}, \mathrm{Wo}_{2-5}$ in sample $12-20-3 ; \mathrm{En}_{71-72}, \mathrm{Wo}_{2-3}$ in sample $12-20-8$. Clinopyroxene crystallized from the breakdown reaction is augite and diopside; diopside forming only in breakdown products in two of the three xenoliths $\left(\operatorname{En}_{36-45}, \mathrm{Wo}_{40-48}\right.$ in sample 12-19-18; $\mathrm{En}_{33-48}, \mathrm{Wo}_{34-45}$ in sample 12-20-3; $\mathrm{En}_{42-53}, \mathrm{Wo}_{25-39}$ in sample 12-20-8). The low-Ca clinopyroxenes in the xenolith breakdown products are subcalcic augite and pigeonite with pigeonite only crystallizing in two of the three samples $\left(\mathrm{En}_{40-58}, \mathrm{Wo}_{19-23}\right.$ in sample 12-19-18; $\mathrm{En}_{43-69}, \mathrm{Wo}_{7-23}$ in sample 12-20-3; $\mathrm{En}_{52}, \mathrm{Wo}_{8-23}$ in sample 12-20-8).

Comparison of the ranges of $\mathrm{Mg}$-numbers of the mafic phases in the breakdown reaction products is shown on Figure 53 and is also compared to the compositions of the mafic phases in the phenocryst breakdown reaction products. The compositional range of the orthopyroxene in samples 12-19-18 and 12-20-8 are matching and are less magnesian 
than the orthopyroxene in 12-20-3. The overall Mg-number range of the orthopyroxene in the reaction products of the three cumulate xenoliths is more magnesian than in the phenocryst reaction products. In sample 12-20-3 there is a bimodal distribution of olivine compositions similar to the trend in the phenocryst reaction products, however, the upper end of the range in 12-20-3 is not as magnesian. The lower end of the range of $\mathrm{Mg}$ numbers for olivine in 12-20-3 overlaps with the olivine compositions of both sample 1219-18 and the phenocryst reaction products and the hornblende compositions of the phenocrysts and all three cumulate xenoliths. The pigeonite follows the same trend as in the phenocryst reactions where the distribution of Mg-numbers is bimodal or nearly bimodal, and the lower end of the compositional range is lower than all other Mg-number ranges. The upper end of the pigeonite ranges in all three cumulate xenoliths overlaps the clinopyroxene ranges. Overall, Mg-number ranges of clinopyroxene in all three cumulate xenoliths are overlapping although some outlying points are more and less magnesian. This range also overlaps the clinopyroxene Mg-number range in the phenocryst reaction products. With the exception of orthopyroxene, the elemental compositions and Mgnumbers of all phases in the breakdown products of both the phenocrysts and coarse grains in the cumulate xenoliths are similar. In addition, the elemental compositions and Mg-numbers of the original hornblende crystals are similar. This match in composition supports the idea of crystallization of both the hornblende phenocrysts and the coarse grained hornblende in the gabbroic xenoliths from similar liquids.

\subsection{Cr Contents of the Hornblende}

Costa et al. (2002) suggested that crystallization of hornblende and phlogopite in gabbroic xenoliths in lavas from Volcán San Pedro, TSVZ, is the result of reaction 
between migrating evolved melts \pm aqueous fluids and anhydrous cumulus minerals. Volcán San Pedro is located in the Southern Volcanic Zone in Chile, north of Volcán Calbuco, at $36^{\circ} \mathrm{S}$ latitude. The gabbroic xenoliths studied were found within dacitic and andesitic lava flows and have been classified by the authors into two groups. The first group consists of olivine-hornblende norites and melanorites with interstitial glass surrounded by euhedral crystals. The second group includes clinopyroxene leuconorites and hornblende leuconorites, both of which exhibit subsolidus exsolution and deformation textures. Costa et al. (2002) cite high $\mathrm{Cr}_{2} \mathrm{O}_{3}$ contents and high Mg-numbers of the hornblende and phlogopite crystals and high $\mathrm{Na}_{2} \mathrm{O}$ wt $\%$ of phlogopite as evidence for crystallization as a result of reaction. They report (Table 7) $\leq 1.2 \% \mathrm{Cr}_{2} \mathrm{O}_{3}$ in hornblende for group I xenoliths and $\leq 0.6 \% \mathrm{Cr}_{2} \mathrm{O}_{3}$ for group II xenoliths and in phlogopite $\leq 0.6 \% \mathrm{Cr}_{2} \mathrm{O}_{3}$ for group I xenoliths and $\leq 0.4 \% \mathrm{Cr}_{2} \mathrm{O}_{3}$ for group II xenoliths. The Mg-numbers in hornblende range from $72-80$ in group I xenoliths and group II xenoliths with hornblende; group II xenoliths with clinopyroxene have Mg-numbers ranging from 64-77. For the phlogopite, the Mg-numbers in group I xenoliths range from 77-82, and in group II from 77-84 for samples containing hornblende and from 70-81 in samples containing clinopyroxene. The reported $\mathrm{Na}_{2} \mathrm{O} w t \%$ of their phlogopite is 2.21 3.36 for group I xenoliths, 1.13-1.92 for group II xenoliths with clinopyroxene, and 1.944.08 for group II xenoliths with hornblende. Phlogopite is found in only one cumulate xenolith from Calbuco and ranges from 1.34-1.94 wt $\% \mathrm{Na}_{2} \mathrm{O}$, which does overlap the values in the group II xenolith with clinopyroxene from Costa et al. (2002).

Gabbronorite xenoliths erupted in Calbuco andesites have $\mathrm{Cr}_{2} \mathrm{O}_{3}$ contents ranging from $0.002-0.08 \mathrm{wt} \%$ in the hornblende, with five anomalously high values from 0.12 - 
0.27 , and $0.02 \mathrm{wt} \%$ in the phlogopite. For hornblende only four data points fall into the range of $\mathrm{Cr}_{2} \mathrm{O}_{3}$ wt\% reported by Costa et al. (2002), and all of the phlogopite has lower concentrations; however the hornblende and phlogopite Mg-numbers do fall into the Costa et al.'s reported range (hornblende: 65-71; phlogopite: 77-79). The lower $\mathrm{Cr}_{2} \mathrm{O}_{3}$ contents of found at Calbuco suggests crystallization of the Calbuco hornblende from a more Cr-poor liquid than that from which the Volcán San Pedro hornblendes crystallized.

\subsection{Compositional Zoning}

Compositional zoning in hornblende, found in phenocrysts in Soufrière Hills andesites, is typically not optically distinguishable, but can be present as inverse variations of $\mathrm{MgO}+\mathrm{SiO}_{2}$ with $\mathrm{FeO}_{\text {total }}+\mathrm{Al}_{2} \mathrm{O}_{3}$ (Rutherford and Devine, 2003). There is evidence of zoning in all three cumulate xenolith samples, as well as the analyzed phenocryst. In all hornblende analyzed, there is a trend toward higher Si contents in the hornblende formula near the breakdown reaction products, and sometimes an increase in Mg-number. Edenite has higher Si contents in the formula than pargasite, and the presence of edenite in the both the cumulate xenoliths and phenocrysts appears to be the result of compositional variation in the hornblende as it is breaking down.

\subsection{Hornblende Stability}

Experimental determination of hornblende stability has been explored under varying water saturation, oxygen fugacity, initial composition, and temperature conditions. Sisson and Grove (1993a) have conducted experiments on high-alumina basalts (HAB) at $2 \mathrm{~kb}$ water saturated conditions and found that hornblende is a nearliquidus mineral in $\mathrm{HAB}$ if the starting material has at least $3 \mathrm{wt} \% \mathrm{Na}_{2} \mathrm{O}$. If less than 3 $w t \% \mathrm{Na}_{2} \mathrm{O}$ is present, hornblende will not appear until the liquid differentiates to the 
point of andesite. Their findings are in agreement with that of Cawthorn and O'Hara (1976) who reported the same $\mathrm{Na}_{2} \mathrm{O}$ wt\% constraints on hornblende crystallization at $5 \mathrm{~kb}$ water saturated conditions. Hornblende can be used as an indicator of pressure, temperature, volatile content, and oxidation state of the magma (Ghiorso and Evans, 2002). Pressure, temperature, and water contents of hornblende formation are discussed below, however, oxygen fugacity was not able to be determined from the present data. An attempt was made to determine oxygen fugacity of the hornblende breakdown reaction based on published coexisting magnetite and ilmenite compositions from Spencer and Lindsley (1981), however it could not be determined because the compositional range was too wide.

\section{6a Pressure}

The $\mathrm{Al}^{\mathrm{T}}$ versus $\mathrm{Al}^{\mathrm{iv}}$ relationship in hornblende has been used by Hammarstrom and Zen (1986) to calculate an igneous geobarometer. $\mathrm{Al}^{\mathrm{iv}}$ is the $\mathrm{Al}$ which fills the remaining space in the $\mathrm{T}$ sites, after $\mathrm{Si}$, in the crystal structure. Their formula calculates the pressure of hornblende crystallization to within \pm 2 kbars (Table 6). Use of hornblende for this type of calculation must be done under the assumption that the magmatic Al content in the crystal is preserved. Hammarstrom and Zen (1986) found that the $\mathrm{Al}$ content is preserved due to the fact that $\mathrm{Al}$ is one of the least mobile elements in a crystalline environment and that diffusion of Al within the hornblende would take orders of magnitude longer than crystallization in a slow cooling pluton. Their geobarometer does however require the coexistence of quartz with the hornblende to "lock" the Si content in the crystal due to the negative correlation of $\mathrm{Al}^{\mathrm{iv}}$ content with $\mathrm{Si}$ in the hornblende structure. According to Rutherford and Devine (2003), hornblende not 
in equilibrium with quartz will have higher $\mathrm{Al}_{2} \mathrm{O}_{3}$ contents than it would if it were in equilibrium with quartz. Rutherford and Devine (2003) have used an alternative Al in hornblende geobarometer to calculate pressures at Soufrière Hills without quartz and hornblende existing in equilibrium. They found that the use of the geobarometer without the required mineral stability was justified due to the fact that it returned a pressure which was consistent with the necessary water pressure to produce the $\mathrm{H}_{2} \mathrm{O}$ observed in melt inclusions. Higher $\mathrm{Al}$ contents in the hornblende, caused by the lack of quartz in the mineral assemblage at Calbuco, used in Hammarstrom and Zen's calculation will return higher values for pressure than if quartz was crystallized from the magma. Under these conditions, the calculated pressure values could represent the upper limit of the possible pressure range. The overall range of calculated pressures for the hornblende phenocryst is $6-8 \pm 2$ kbars. For the cumulate xenoliths, the calculated pressure ranges are $4-7 \pm 2$ kbars for sample 12-19-18, 3-11 \pm 2 kbars for sample 12-20-3, 3-8 2 kbars for sample 12$20-8$, and $3-10 \pm 2$ kbars for sample 12-18-1. The phenocryst and cumulate xenolith $12-$ 19-18 have the same narrow range of calculated pressures, within error, but the three remaining cumulate xenolith samples have broad calculated pressure ranges and only overlap the range of the hornblende phenocryst and sample 12-19-18 at the lower end of the broad range.

Experimentally derived phase diagrams (Figure 61) have been constructed for lower pressure ranges for andesite (1.25-4 kbars) and basaltic andesite (2-4 kbars) than the $\mathrm{Al}$ in hornblende calculation. Based on the total mineral assemblage at Calbuco, the pressure ranges inferred from individual phase diagrams are $1.25+$ kbars (Rutherford and Devine, 2003), 1.5-2.25 kbars (Luhr, 2002), and 4 kbars (Pichavant et al., 2002) for 
andesites, and 2+ kbars (Rutherford and Devine, 2003), up to $2.1 \mathrm{kbars}$ (Luhr, 2002), and 4 kbars (Pichavant et al., 2002) for basaltic andesite. These pressures correspond to depths of $3.8+\mathrm{km}, 4.5-6.8 \mathrm{~km}$, and $12 \mathrm{~km}$ for andesite respectively and $6.7+\mathrm{km}, 1.2-6.3$ $\mathrm{km}$, and $12 \mathrm{~km}$ for basaltic andesite respectively. As expected from the lack of equilibrium of the hornblende with quartz, the pressures extrapolated from these phase diagrams is lower than the pressure calculated with the geobarometer from Hammarstrom and Zen (1986).

\section{$5.6 b$ Temperature}

Thermometry calculations of melt in equilibrium with hornblende also require that the melt be quartz saturated. No quartz has been found in any of the andesite from Calbuco and high- $\mathrm{Al}_{2} \mathrm{O}_{3}$ contents of the hornblende suggest that quartz could not be crystallizing (Rutherford and Devine, 2003). Following the reasoning above, an attempt was made at temperature calculations using the plagioclase-hornblende geothermometer from Holland and Blundy (1994). For the overall pressure range of 1-4 kbars and dissolved $\mathrm{H}_{2} \mathrm{O}$ range of 4-7 wt $\%$, the calculated temperature range is approximately $840-$ $930^{\circ} \mathrm{C}$ for the phenocryst and approximately $900-1090^{\circ} \mathrm{C}$ for the three xenoliths collectively. Published phase diagrams (Figure 61) for volcanic rocks of similar composition and mineral assemblage show the first appearance of hornblende with cooling of the magma from approximately $900-1000^{\circ} \mathrm{C}$. Based on experimental phase assemblages and the observed mineral assemblage of the andesite and basaltic andesite from Calbuco, an overall temperature range for the eruptive products is $845-975^{\circ} \mathrm{C}$ for the andesites and $900-1145^{\circ} \mathrm{C}$ for basaltic andesites. According to individual phase diagrams, the temperature ranges for phase stability are $845-895^{\circ} \mathrm{C}$ for andesite, 900 - 
$950^{\circ} \mathrm{C}$ for basaltic andesite (Rutherford and Devine, 2003), $925-975^{\circ} \mathrm{C}$ for andesite and $975-1145^{\circ} \mathrm{C}$ for basaltic andesite (Luhr, 2002), and $935-970^{\circ} \mathrm{C}$ for andesite and $935+{ }^{\circ} \mathrm{C}$ for basaltic andesite depending on $\mathrm{H}_{2} \mathrm{O}$ concentration (Pichavant et al., 2002). Overall, these published temperatures overlap the calculated temperatures, despite the lack of quartz in equilibrium with the hornblende.

\section{6c Water Content}

Rutherford and Devine (2003) and Luhr (2002) have conducted experiments under water saturated conditions using Soufrière Hills and Colima andesite respectively, Pichavant et al. (2002) have conducted experiments under water under-saturated conditions using Mt. Pelée basaltic andesite, all of which have a similar mineral assemblage to Calbuco andesites and basaltic andesites. Phase diagrams have been constructed (Figure 61) using wt\% water in the magma as one of their parameters by Luhr (2002) and Pichavant et al. (2002). At 4 kbars pressure, hornblende is stable above $5 \mathrm{wt} \% \mathrm{H}_{2} \mathrm{O}$ (Figure 61C) and at a pressure range of $1-3 \mathrm{kbars}$ hornblende is stable from $2-7+\mathrm{wt} \% \mathrm{H}_{2} \mathrm{O}$ (Figure 61B).

\subsection{Summary}

Hornblende is found in Calbuco eruptive products as phenocrysts and as coarse grains in gabbroic xenoliths. In both instances, the mineral chemistry is overlapping and the crystals are pargasite, a variety of calcic hornblende. Hornblende phenocrysts are chemically stable in the andesite, but are breaking down due to changes in physical properties in the magma chamber, such as decompression on ascent, dehydration of the magma, and oxidation of the magma. This breakdown forms three types of reaction products, 1) reaction rims and 2) "gabbroic type" reaction products, both found only in 
association with phenocryst breakdown, and 3) opacite found on all hornblende crystals. Chemical analysis of opacite in phenocryst and gabbroic coarse grained hornblende breakdown shows that the mineral make-up of the opacite consists of microcrystalline plagioclase, olivine, magnetite, clinopyroxene, and orthopyroxene.

$\mathrm{Cr}$ contents of the hornblende and phlogopite from Calbuco have also been compared to $\mathrm{Cr}$ contents reported for the same minerals for Volcán San Pedro. The high Cr contents of these two mineral phases in Volcán San Pedro eruptive products have been cited by Costa et al. (2002) as evidence for their formation as a result of reaction between migrating evolved melts \pm aqueous fluids and anhydrous cumulus minerals. Cr contents for hornblende and phlogopite from Calbuco are significantly lower than those reported for Volcán San Pedro.

Determination of hornblende stability ranges for pressure and temperature of phenocrysts and gabbroic coarse grains has been attempted using published calculations. Calculations for both pressure and temperature of hornblende crystallization require the coexistence of quartz, to stabilize the Si content in the hornblende crystal structure, which does not crystallize in Calbuco andesite. Despite the lack of quartz, a calculated pressure range of 3-1 $1 \pm 2$ kbars was determined for gabbroic xenolith hornblende, which is likely to have been affected by the lack of quartz in equilibrium, and 6-8 \pm 2 kbars for phenocryst hornblende, higher than the range (1.25-4 kbars) extrapolated from published phase diagrams of andesite with a similar mineral assemblage. In contrast to the pressure calculations, temperature calculations for both phenocryst $\left(840-930^{\circ} \mathrm{C}\right)$ and coarse grained gabbroic hornblende $\left(900-1090^{\circ} \mathrm{C}\right)$ overlap the temperature ranges $\left(845-975^{\circ} \mathrm{C}\right)$ extrapolated from published the same phase diagrams. 



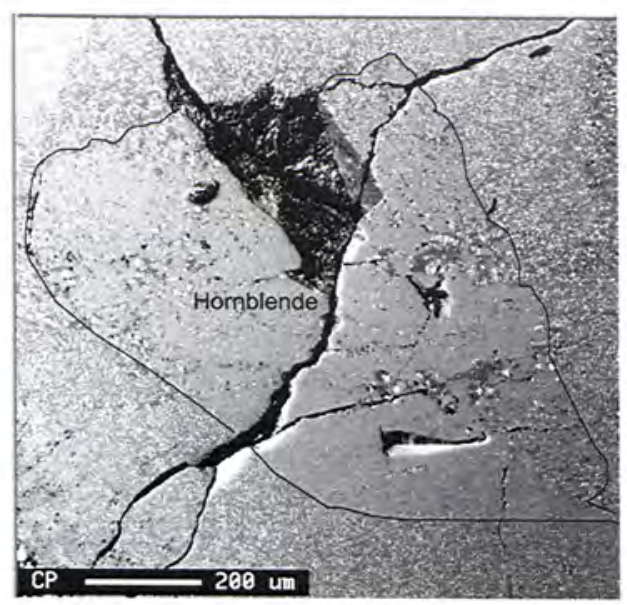

Figure 46: BSE images of hornblende pseudomorphs.

A, B, C: Back-scattered electron images of pseudomorph of hornblende phenocryst breakdown reaction products. $\mathrm{C}$ : partially reacted hornblende grain (outlined) remaining in center of reaction products. 


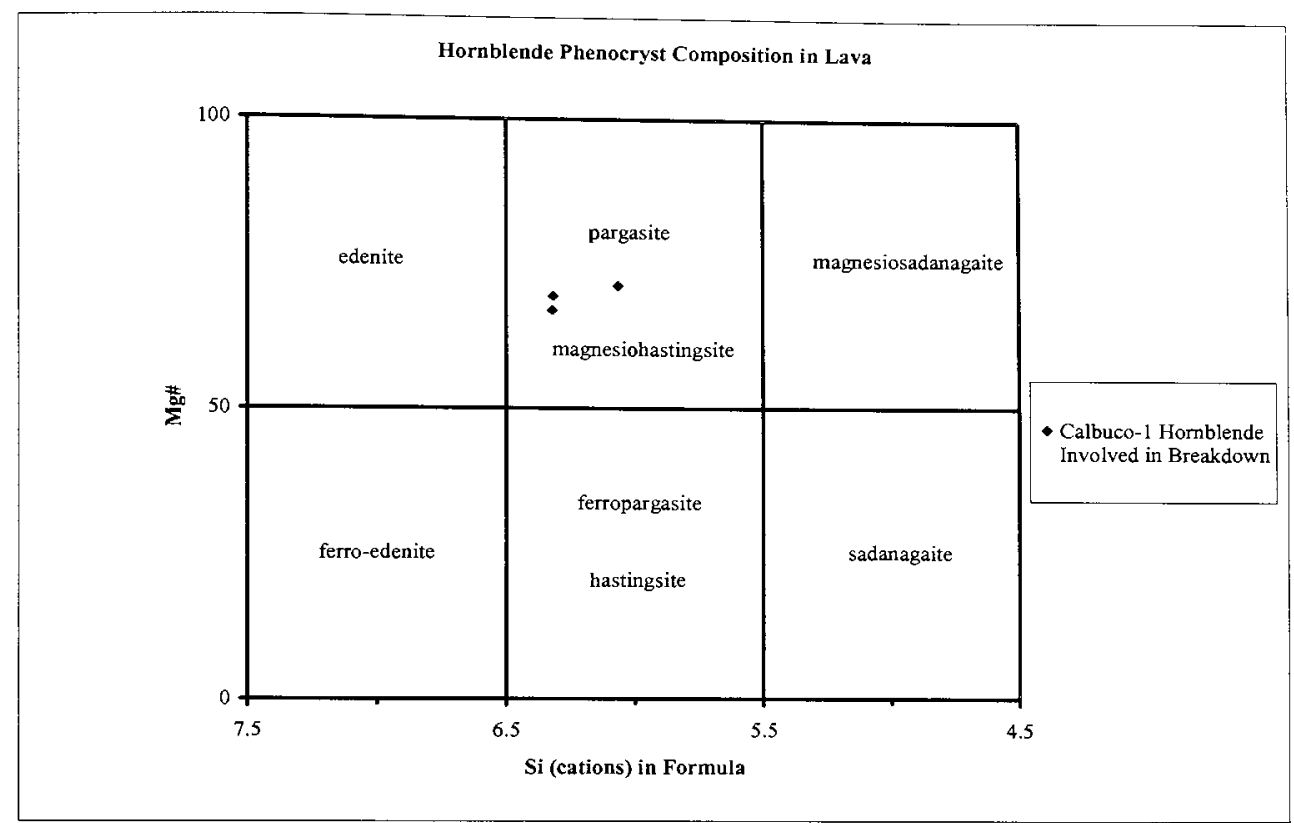

Figure 47: Hornblende phenocryst composition.

Plot of Si cations in recalculated hornblende formula against $\mathrm{Mg}$-number of hornblende phenocryst. Recalculation and plot after Leake et al., 1997. 

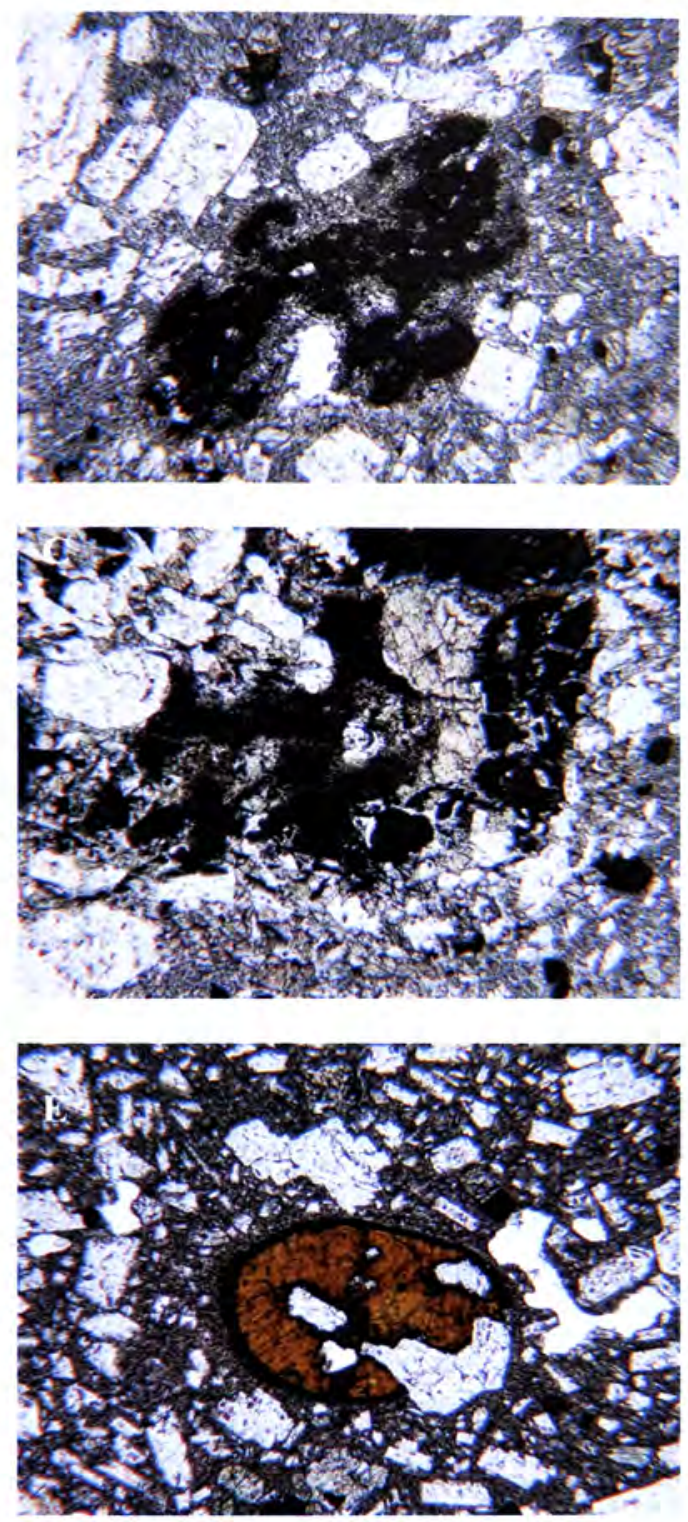
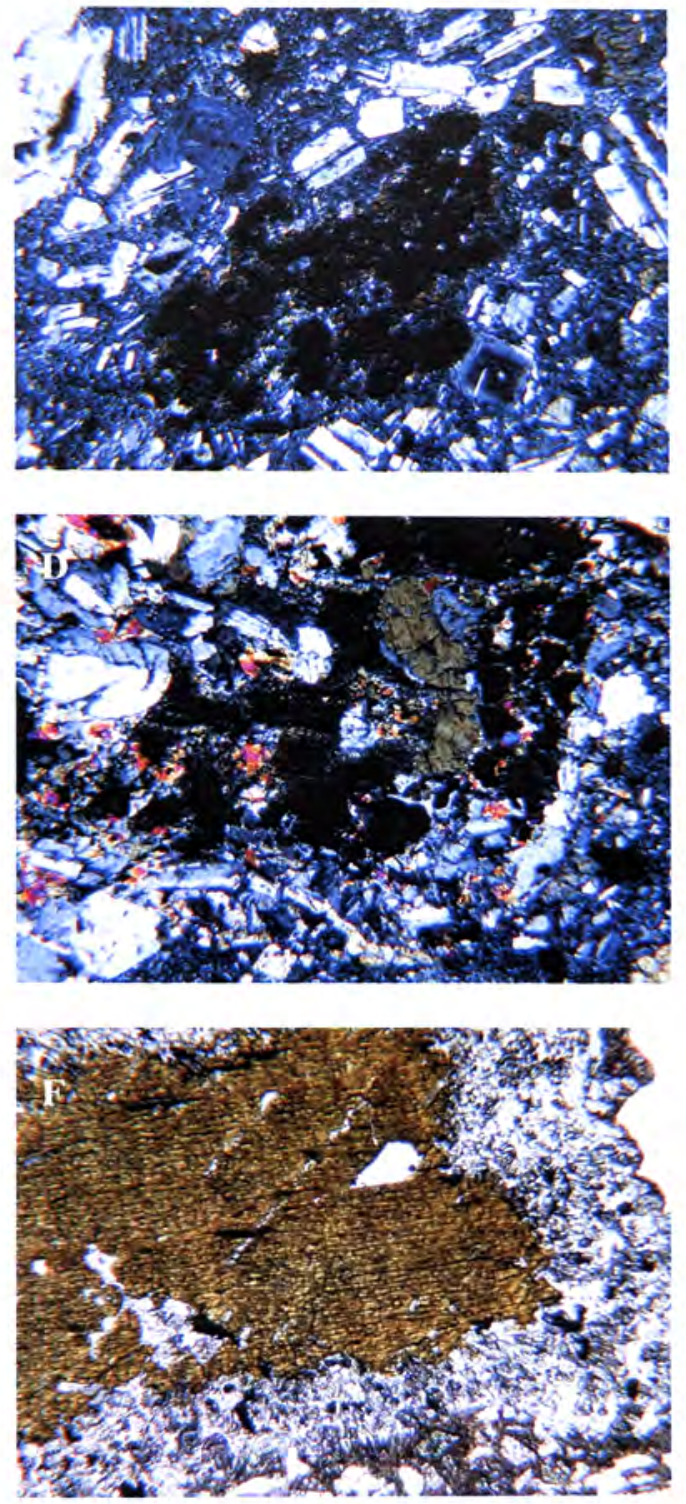

Figure 48: Photomicrographs of hornblende phenocryst breakdown reaction products.

Photomicrographs of hornblende phenocrysts showing "black type" and "gabbroic type" breakdown reaction products and reaction rims. A, B: Hornblende in plane-polarized (A) and cross-polarized (B) light showing "black type" breakdown reaction products. C, D: Hornblende in plane-polarized (C) and cross-polarized (D) light showing "gabbroic type" breakdown reaction products. The "black type" reaction product is also present. E: Hornblende in plane polarized light with a microcrystalline opacite reaction rim. F: Hornblende in plane polarized light with a white reaction rim consisting predominantly of plagioclase and pyroxene. Field of view is $2.8 \mathrm{~mm}$. 


\begin{tabular}{|c|c|c|c|c|c|c|c|c|c|c|c|c|c|c|c|c|c|c|c|}
\hline 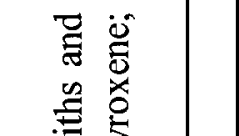 & $\underline{\underline{E}}$ & 촌 & & & 1 & ' & ' & ' & 1 & & 1 & I & 1 & ' & $\vec{b}$ & 1 & & ' & ' \\
\hline 월 & $\sum^{80}$ & $=\sqrt[5]{5}$ & & ?ై & $\frac{m}{6}$ & $\begin{array}{l}0 \\
\dot{0} \\
0\end{array}$ & 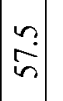 & 1 & $\stackrel{0}{2}$ & ' & 1 & ฉ̀ & $\mid \begin{array}{l}\infty \\
\dot{\alpha}\end{array}$ & 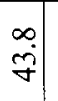 & $\stackrel{\mathrm{i}}{\mathrm{i}}$ & $\mid \begin{array}{l}0 \\
0\end{array}$ & O. & ' & $\vec{\infty}$ \\
\hline 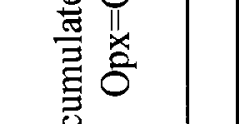 & & 䓵 & & & 1 & ' & ' & & $\stackrel{+}{\dot{\infty}}$ & के & 7 & 1 & I & ' & $\stackrel{0}{\infty}$ & ' & 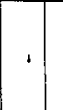 & 1 & \\
\hline 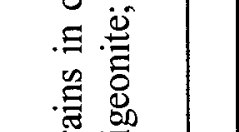 & 0 & $2 \frac{3}{5}$ & & & 1 & ' & ' & ' & $\stackrel{i}{0}$ & $\begin{array}{l}0 \\
0 \\
0\end{array}$ & $\begin{array}{l}3 \\
6 \\
3\end{array}$ & 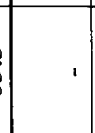 & ' & ' & $\stackrel{\sim}{\infty}$ & 1 & & 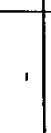 & \\
\hline $\begin{array}{l}\text { का } \|_{1} \\
\text { कू }\end{array}$ & & \& & & ' & $m$ & $\begin{array}{c}0 \\
2 \\
r\end{array}$ & $\stackrel{i}{i}$ & ' & 1 & 1 & ' & ' & ' & ' & 1 & 1 & & & \\
\hline$\stackrel{0}{0}$ & 0 & $\stackrel{3}{3}$ & & ' & $\begin{array}{l}0 \\
-i\end{array}$ & $\left|\begin{array}{l}0 \\
\sim \\
0\end{array}\right|$ & $\left|\begin{array}{l}0 \\
i \\
\sim\end{array}\right|$ & 1 & ' & 1 & 1 & 1 & ' & ' & I & 1 & & & \\
\hline 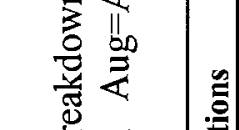 & & 这 & & & $\stackrel{0}{i}$ & $=$ & $\stackrel{\infty}{\stackrel{2}{2}}$ & 1 & ' & 1 & ' & 1 & ' & 1 & I & ' & , & 1 & \\
\hline 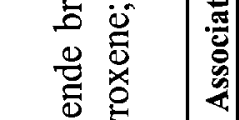 & : & 䒧 & & & $\stackrel{\ominus}{\ominus}$ & ' & ' & 1 & ' & 1 & ' & $\stackrel{\sim}{\mathrm{n}}$ & ' & 1 & ڤึ & I & 1 & ' & $\begin{array}{l}\forall \\
\sim \\
n\end{array}$ \\
\hline 高㑒 & है & $=\frac{5}{2}$ & & & $\begin{array}{c}0 \\
\infty \\
\infty\end{array}$ & ' & ' & 1 & 1 & 1 & ' & $\begin{array}{c}0 \\
\text { ते }\end{array}$ & I & 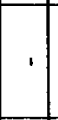 & ָ̊! & ' & 1 & $\cdot$ & $\stackrel{\bullet}{\vec{N}}$ \\
\hline 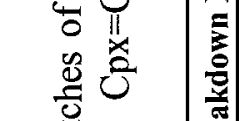 & 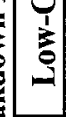 & 송 & & & $\frac{0}{n}$ & ' & ' & 1 & ' & 1 & ' & $\stackrel{\sim}{\mathcal{Q}}$ & & ' & $\begin{array}{l}n \\
8\end{array}$ & ' & ' & ' & $\tilde{y}$ \\
\hline 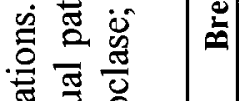 & & 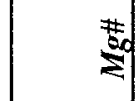 & & & $\begin{array}{l}\infty \\
\stackrel{\infty}{r} \\
\stackrel{n}{0}\end{array}$ & $\begin{array}{l}0 \\
\stackrel{0}{2}\end{array}$ & ' & ' & 1 & $\overrightarrow{8}$ & & $\underset{D}{Z}$ & & 1 & $\frac{a}{N}$ &. & ' & . & \\
\hline 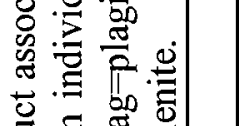 & U⿺ & $\equiv \frac{0}{5}$ & & ‘ & $\vec{j}$ & $\begin{array}{c}0 \\
\dot{g} \\
\dot{\sigma}\end{array}$ & ' & $\cdot$ & 1 & $\stackrel{\circ}{\stackrel{0}{+}}$ & & $\begin{array}{l}\infty \\
\stackrel{0}{ } \\
\dot{n}\end{array}$ & ‘ & ' & $\begin{array}{l}\infty \\
\stackrel{\sim}{0}\end{array}$ & 1 & ' & 1 & ' \\
\hline 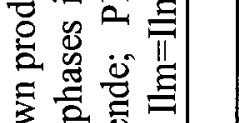 & & $=\frac{20}{8}$ & & & $\begin{array}{l}\vec{v} \\
\vec{v}\end{array}$ & $\begin{array}{l}\stackrel{\sim}{\sim} \\
\dot{y}\end{array}$ & ' & ' & ' & O̊. & & $\begin{array}{l}0 \\
\stackrel{f}{q}\end{array}$ & ' & ' & 高 & 1 & ' & ' & ' \\
\hline 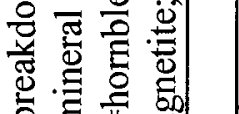 & $\frac{900}{\pi}$ & $=\frac{20}{8}$ & & $\begin{array}{l}n \\
8 \\
8\end{array}$ & $\vec{i}$ & $\begin{array}{c}0 \\
\infty \\
\infty\end{array}$ & $\mid$ & $\stackrel{t}{2}$ & $\begin{array}{c}0 \\
\dot{y}\end{array}$ & ñ & 3 & $\stackrel{\infty}{\dot{0}}$ & $\stackrel{3}{\circ}$ & $\begin{array}{l}0 \\
\text { ț }\end{array}$ & $\stackrel{q}{\dot{y}}$ & $\begin{array}{l}n \\
\dot{q}\end{array}$ & $\underset{\sim}{\tilde{v}}$ & $\begin{array}{l}\infty \\
\grave{m}\end{array}$ & $\bar{\infty}$ \\
\hline 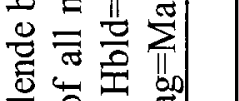 & 든 & 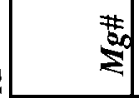 & & $\frac{\square}{\square}$ & $\frac{7}{6}$ & ' & ' & ' & $\frac{-}{6}$ & $\frac{0}{6}$ & & $\begin{array}{l}0 \\
\ddot{0}\end{array}$ & ' & ' & $\begin{array}{l}N \\
8\end{array}$ & . & ' & 1 & $\frac{\pi}{6}$ \\
\hline 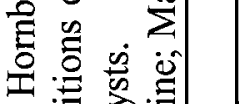 & $\bar{E}$ & ลั้ & & है & is & & & & 㩆 & 哭 & & 焉 & & & 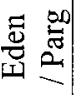 & & & & 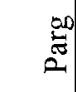 \\
\hline 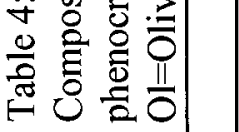 & & $\frac{0}{5}$ & 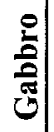 & 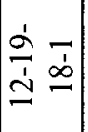 & $\mid \begin{array}{ll}1 & \sim \\
\vdots & 1 \\
\beth & 0\end{array}$ & & & & 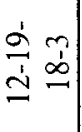 & $\mid \begin{array}{ll}\dot{2} & \\
\dot{1} & 0 \\
& 0\end{array}$ & & 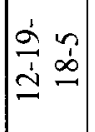 & & & 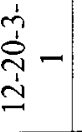 & & & & 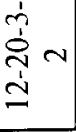 \\
\hline
\end{tabular}




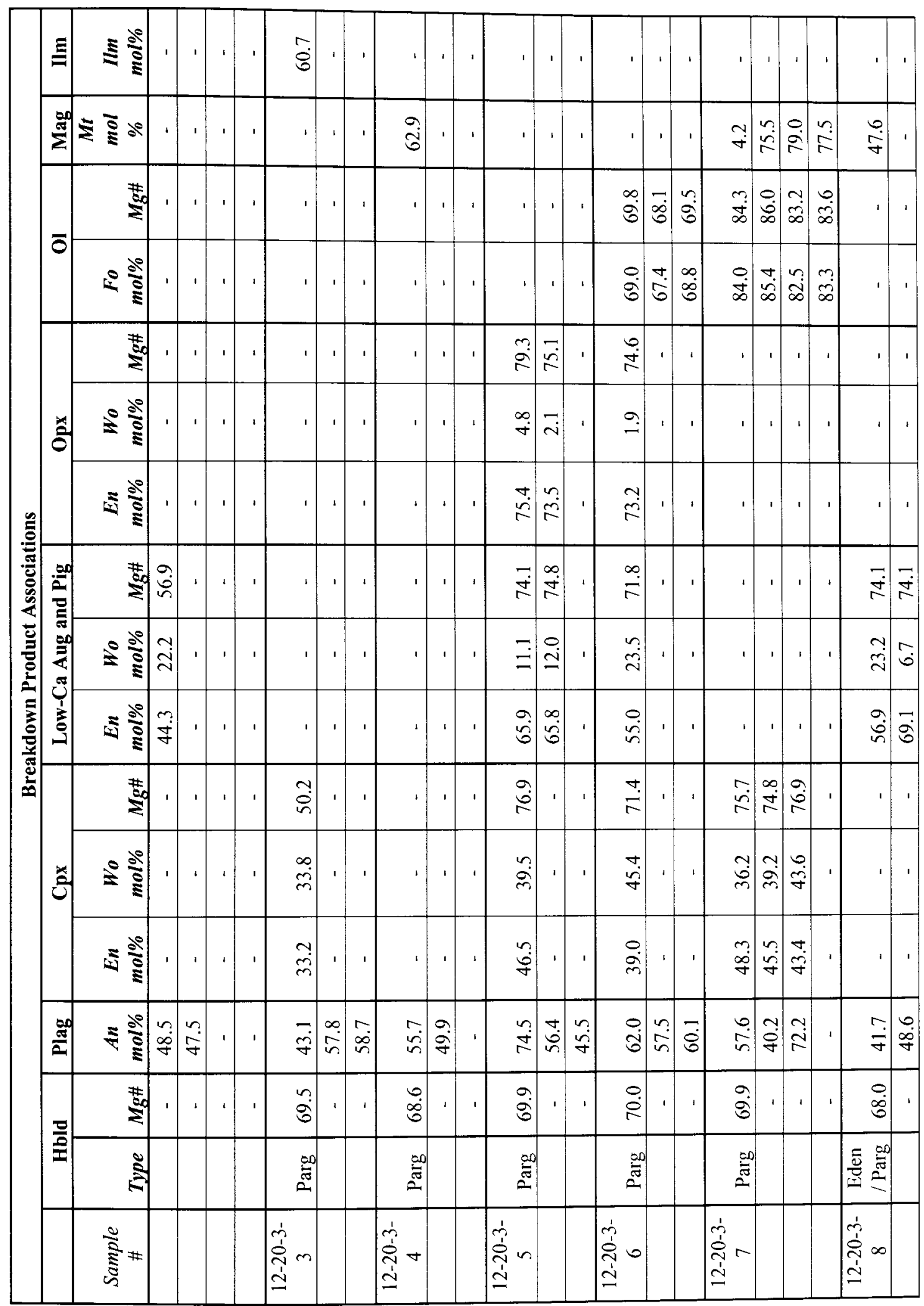




\begin{tabular}{|c|c|c|c|c|c|c|}
\hline 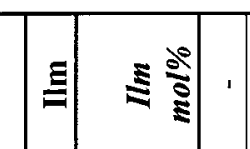 & & & & & & \\
\hline yy & & & & 列 & 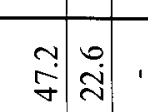 & i) \\
\hline 湆: & & & & |. & 而 & \\
\hline $2 \frac{8}{2}$ & & & &. & , & \\
\hline 溇 & शे & & & \begin{tabular}{|l|l|l|} 
\\
\end{tabular} & י. & \\
\hline 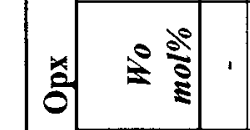 & 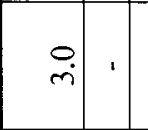 & & & $\approx$ & . & \\
\hline 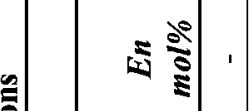 & : & & & $\stackrel{\circ}{=1}$ & 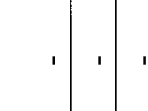 & ' \\
\hline$\frac{1}{4}$ & 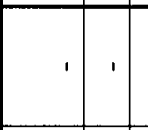 & & & . & : & 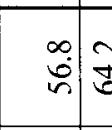 \\
\hline 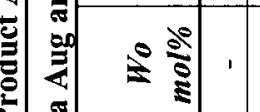 &. & & & & \% & 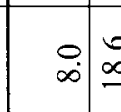 \\
\hline$\left(\begin{array}{lll}n \\
5\end{array}\right.$ & t. & & &. & : & $\mid$ 재예 \\
\hline 亲: & $\frac{0}{0}$ & : & $: 8:$ & & 8 & ' \\
\hline $\begin{cases}0 \\
0\end{cases}$ & 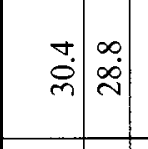 & : & 령 & & +2 & \\
\hline 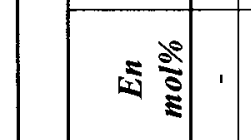 & : & 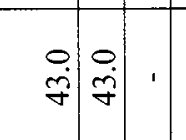 & ㅇ: &. & $\because \%$ & . \\
\hline 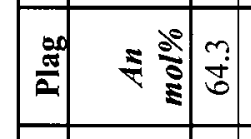 & 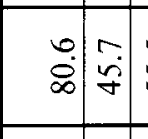 & $\because A$ & $\left(\frac{\infty}{m}\right)$ & 9 & 20 & 匏: \\
\hline 意 & 8 & : & : & : & 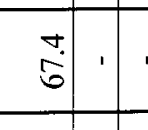 & \begin{tabular}{|l|l|}
3 \\
\end{tabular} \\
\hline 音 & 器 & 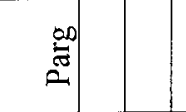 & 部 & : & 部 & 嵒 \\
\hline 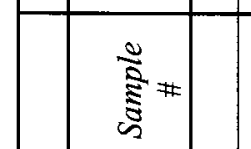 & $\stackrel{3}{3}$ & 先 & 要 & 商- & 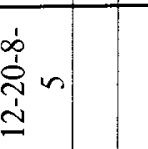 & 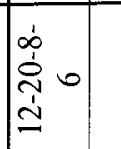 \\
\hline
\end{tabular}




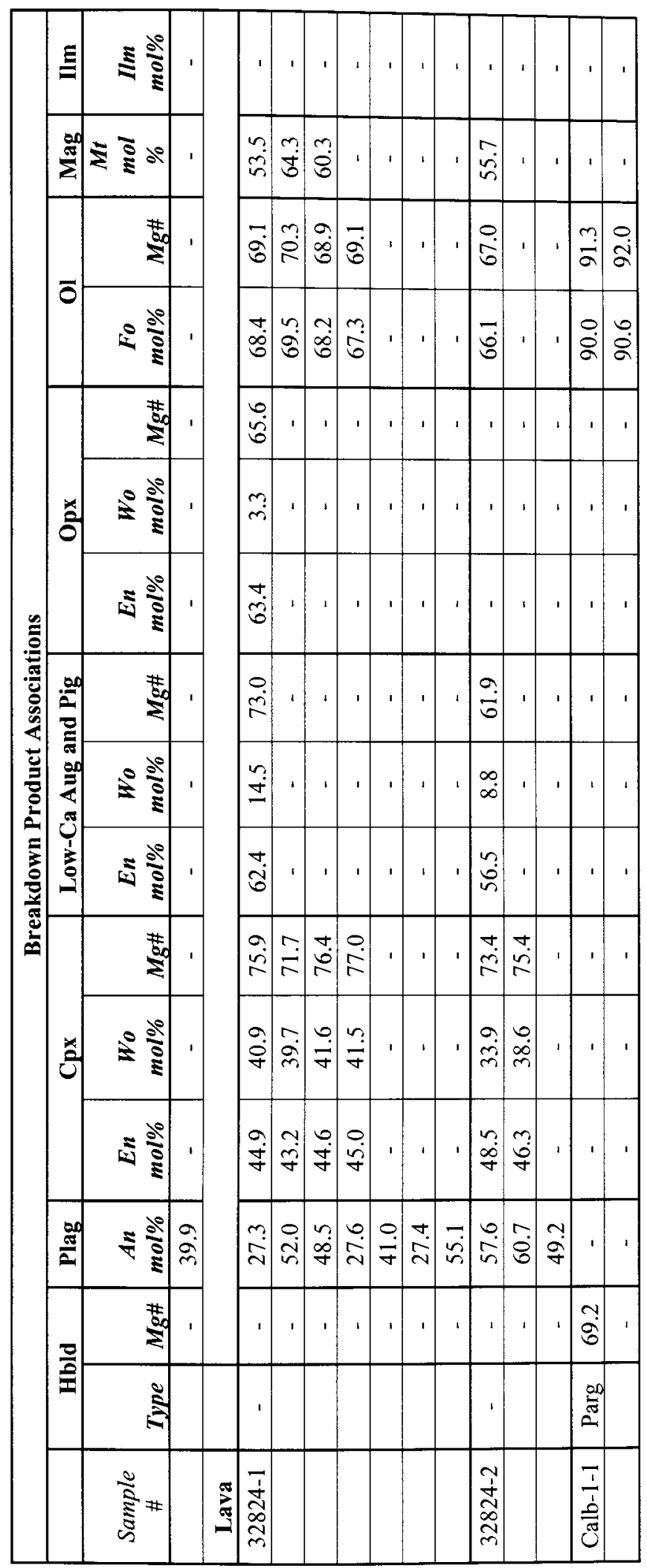




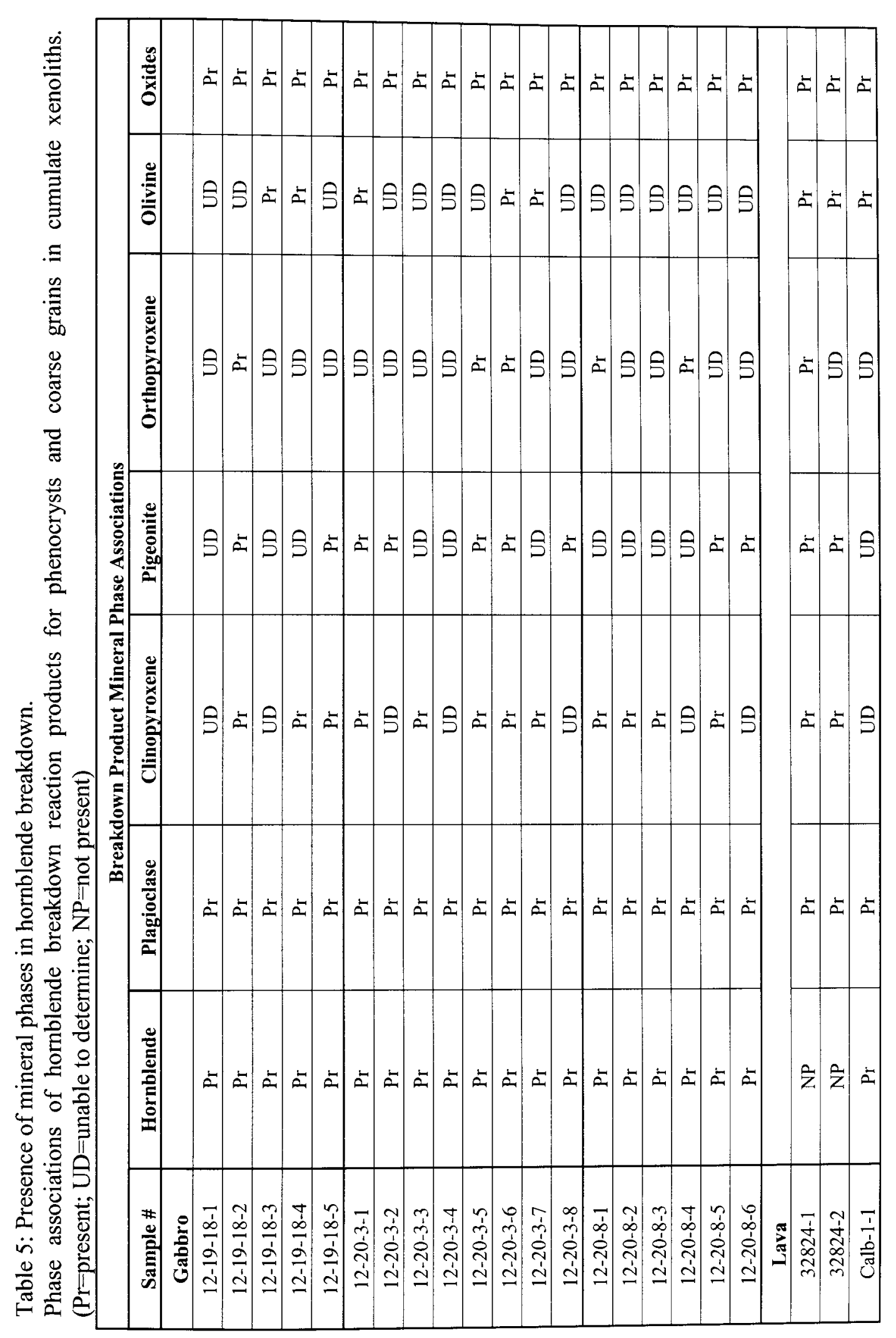




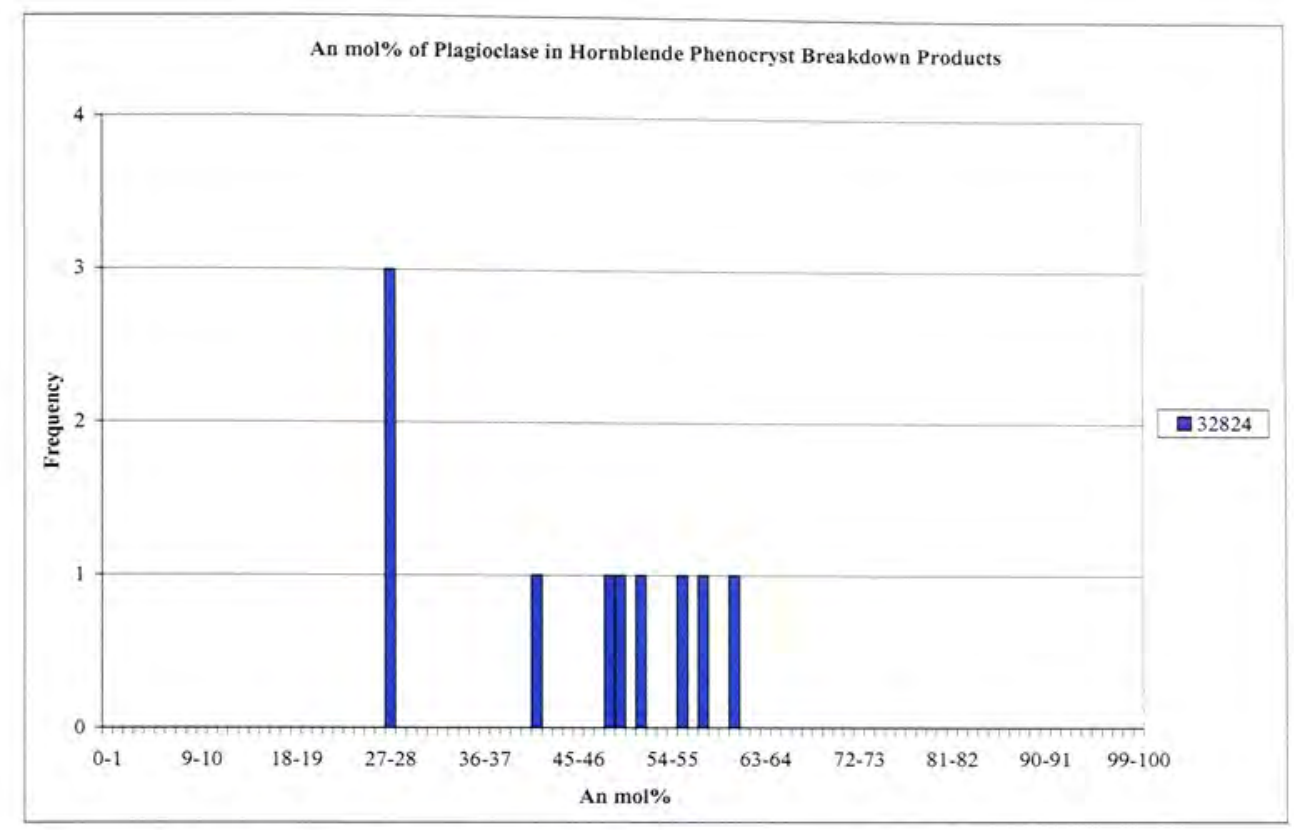

Figure 49: Histogram of plagioclase in hornblende breakdown.

Histogram of frequency versus An mol\% showing the composition of plagioclase in hornblende breakdown products of phenocrysts.

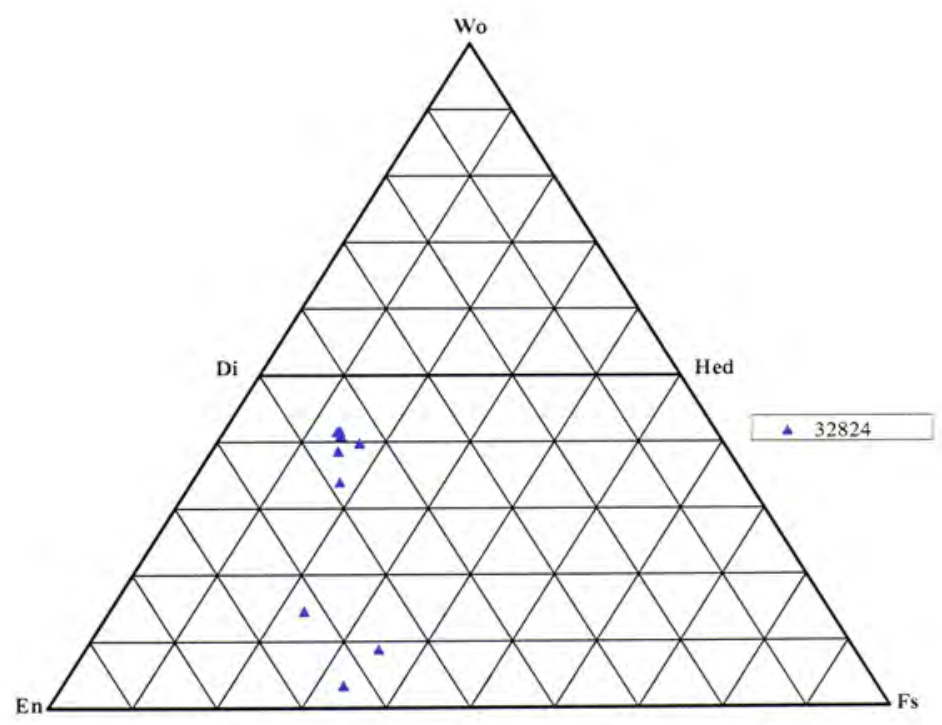

Figure 50: Ternary plot of pyroxene in hornblende breakdown.

Ternary plot showing compositions of ortho- and clinopyroxene in hornblende breakdown products of phenocrysts. 


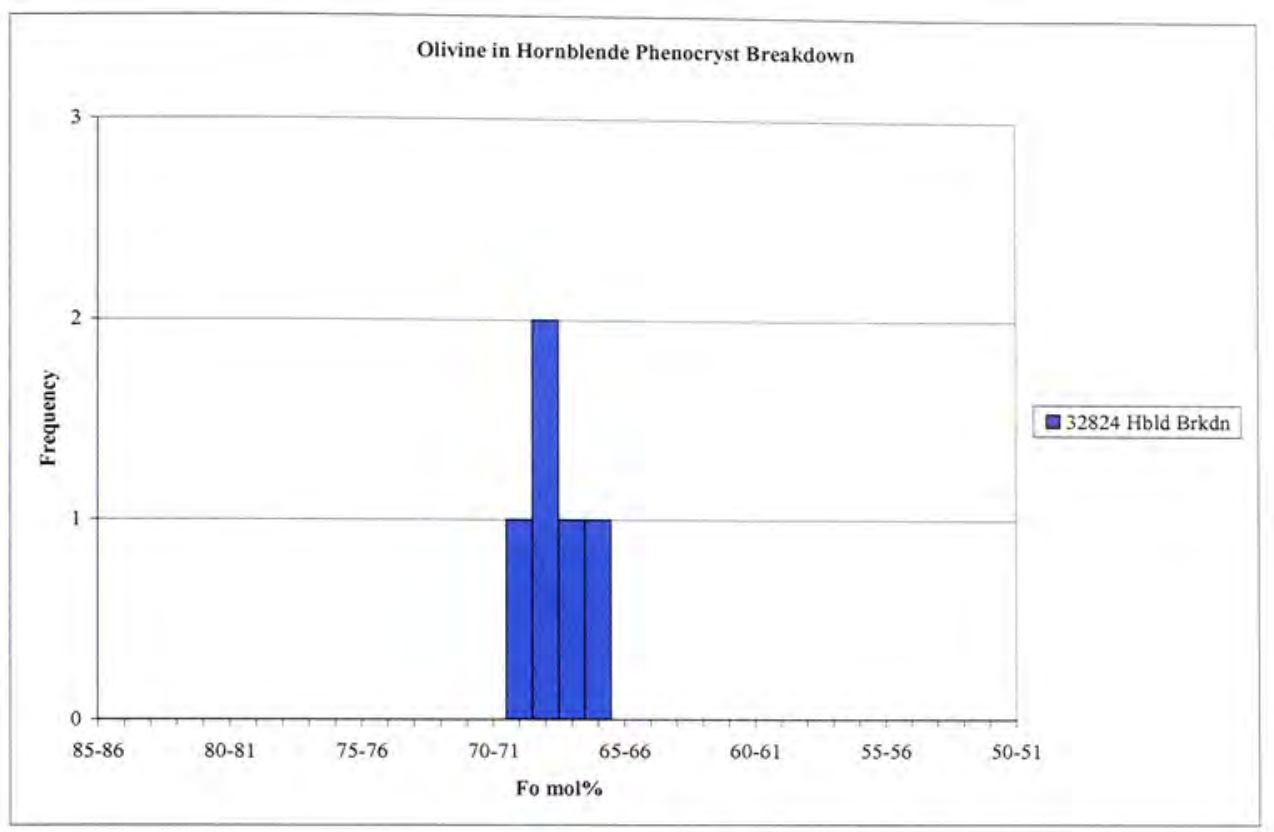

Figure 51: Histogram of olivine in hornblende breakdown.

Histogram of frequency versus Fo mol\% showing composition of olivine in hornblende reaction products of phenocrysts.

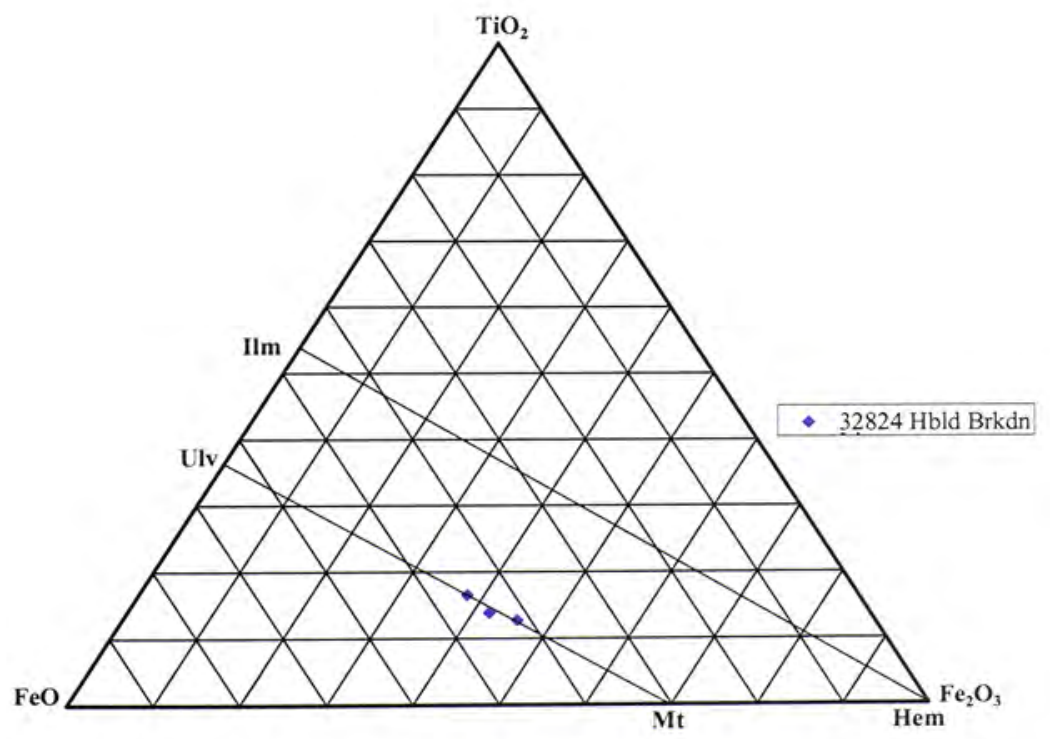

Figure 52: Ternary plot of oxides in hornblende breakdown.

Ternary plot of magnetite composition in hornblende phenocryst breakdown products. 


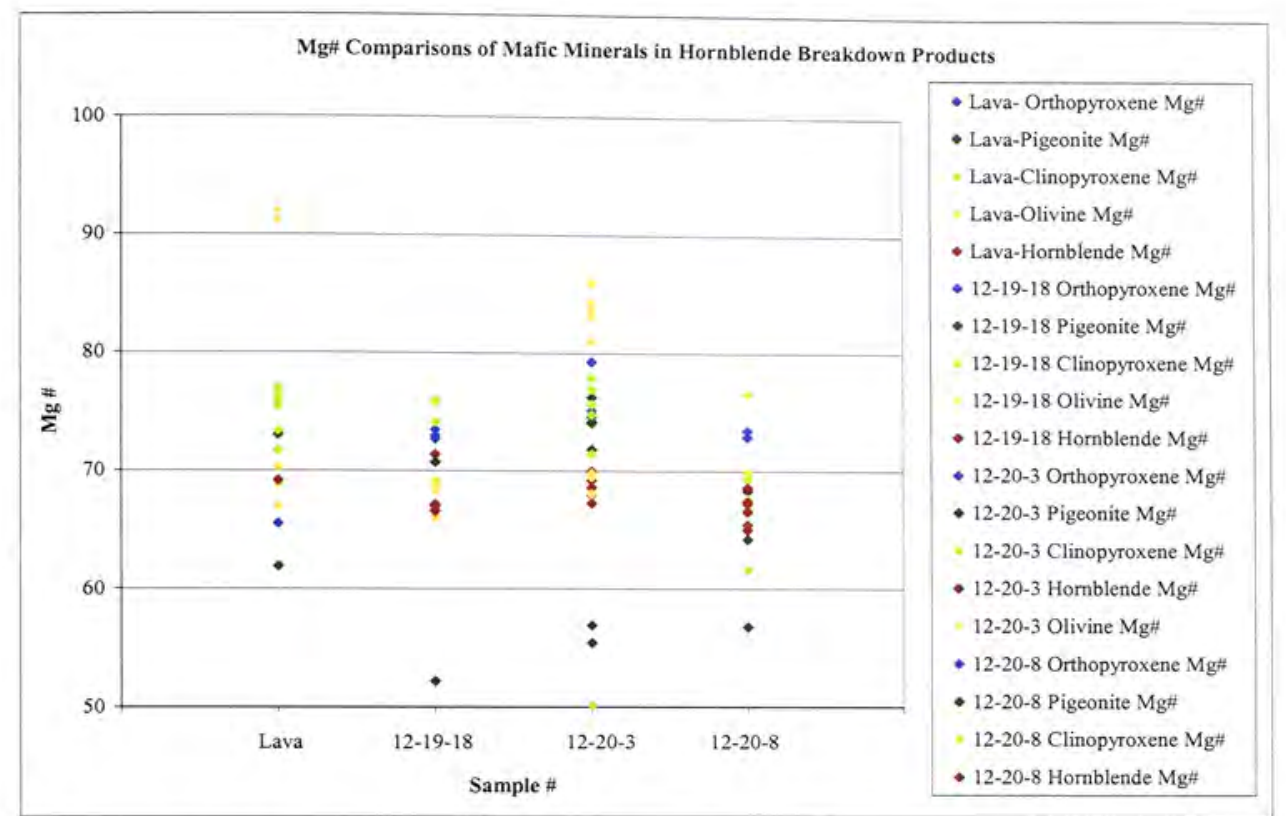

Figure 53: Mg\# of mafic minerals in hornblende breakdown.

Plot comparing Mg-numbers of mafic phases found as phenocrysts in the lava with mafic phases found in cumulate xenoliths.

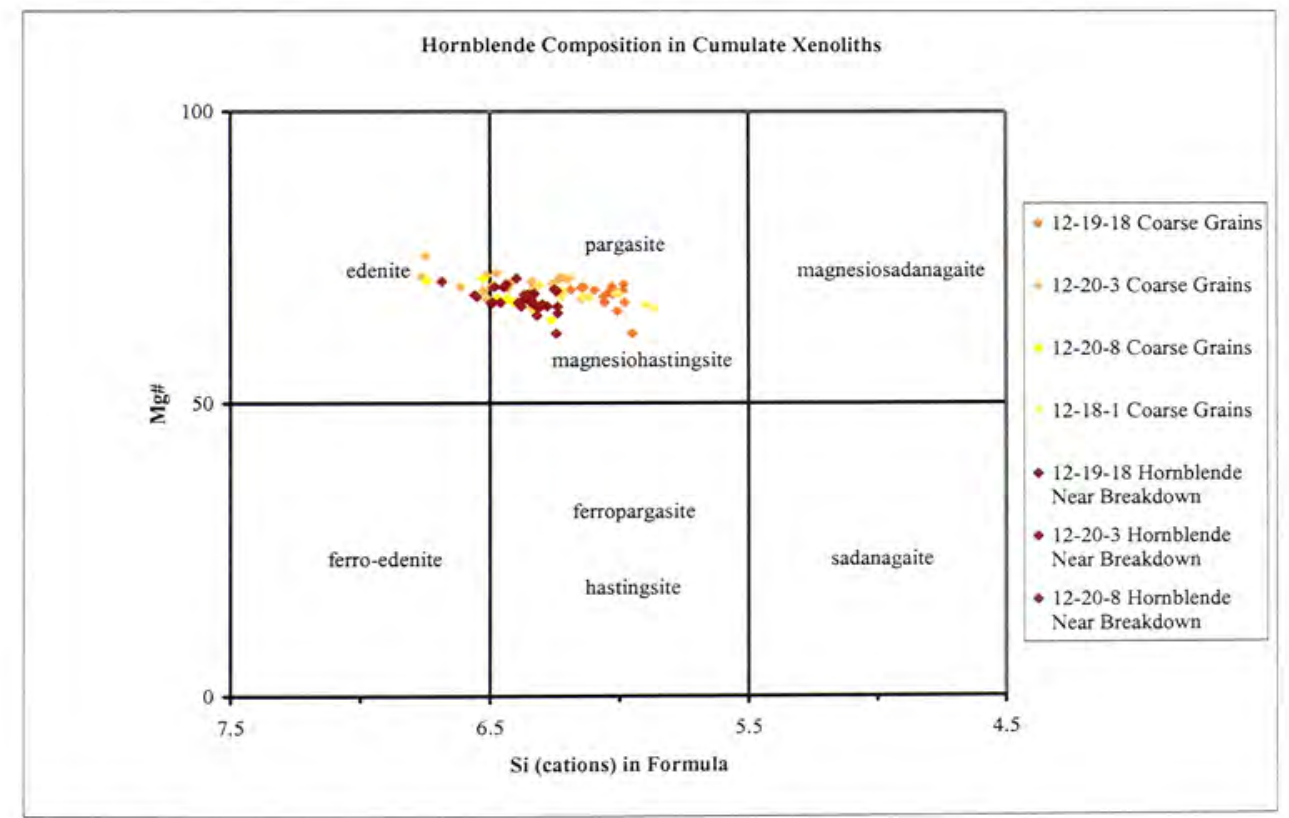

Figure 54: Hornblende composition in gabbroic xenoliths.

Plot of Si cations in hornblende recalculation formula versus Mg-number of hornblende for coarse grained hornblende in cumulate xenoliths. Plot and recalculation after Leake et al., 1997. 

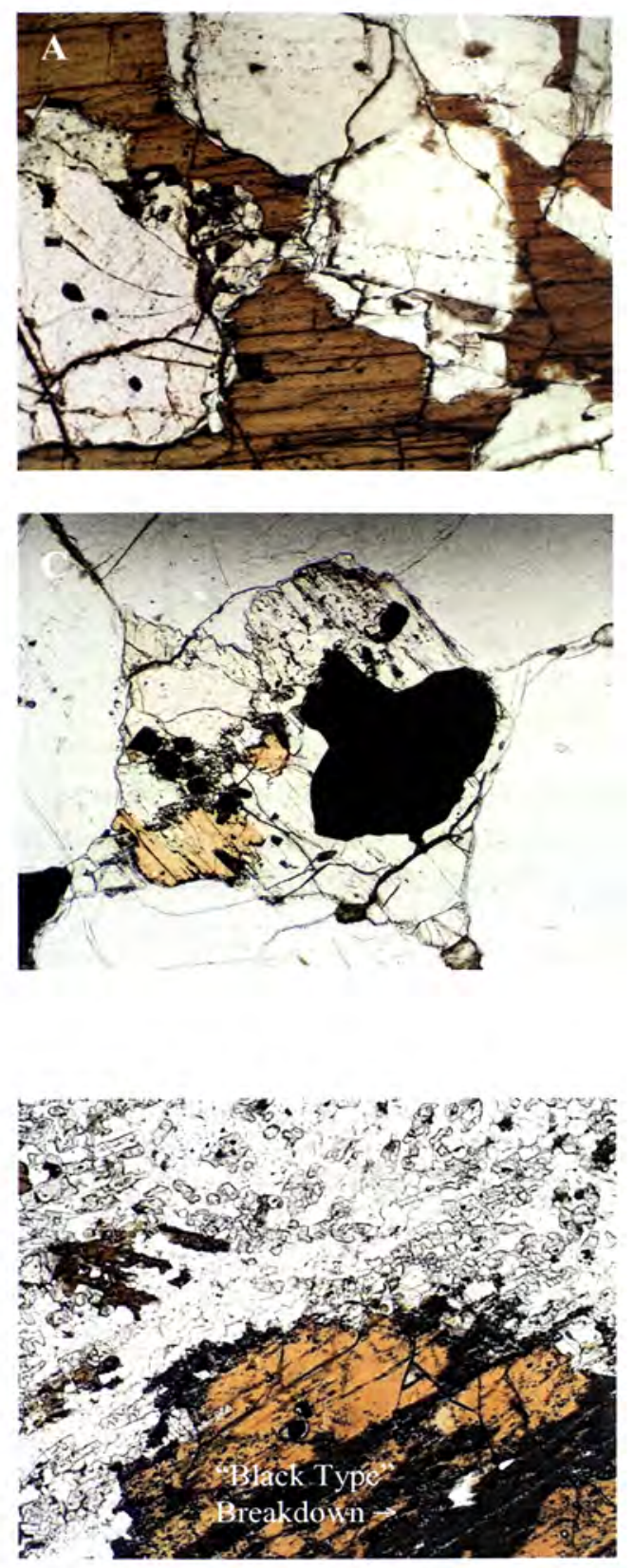

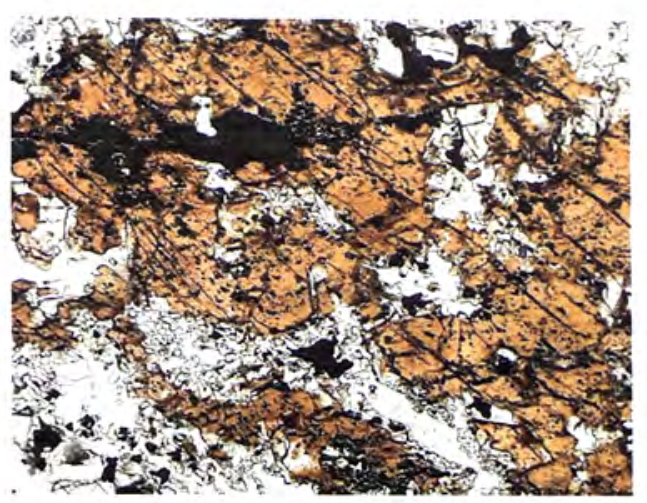

Figure 55: Photomicrographs of hornblende in gabbroic xenoliths.

Photomicrographs in plane polarized light of coarse grained hornblende in three cumulate xenoliths. A: sample 1219-18 showing little hornblende breakdown. B: sample 12-20-3 showing severe breakdown. C: sample 12-20-8 showing moderate breakdown. Field of view is $2.8 \mathrm{~mm}$.

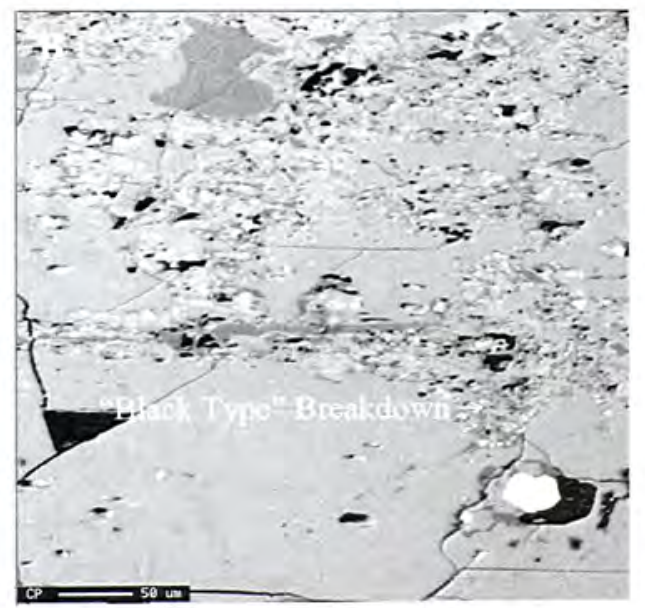

Figure 56: Images of opacite.

A: Photomicrograph of hornblende in plane polarized light showing microcrystalline "black type" breakdown products in coarse grain in cumulate xenolith. Field of view is $2.8 \mathrm{~mm}$. B: Back-scattered electron image showing texture of "black type" hornblende breakdown reaction products. 


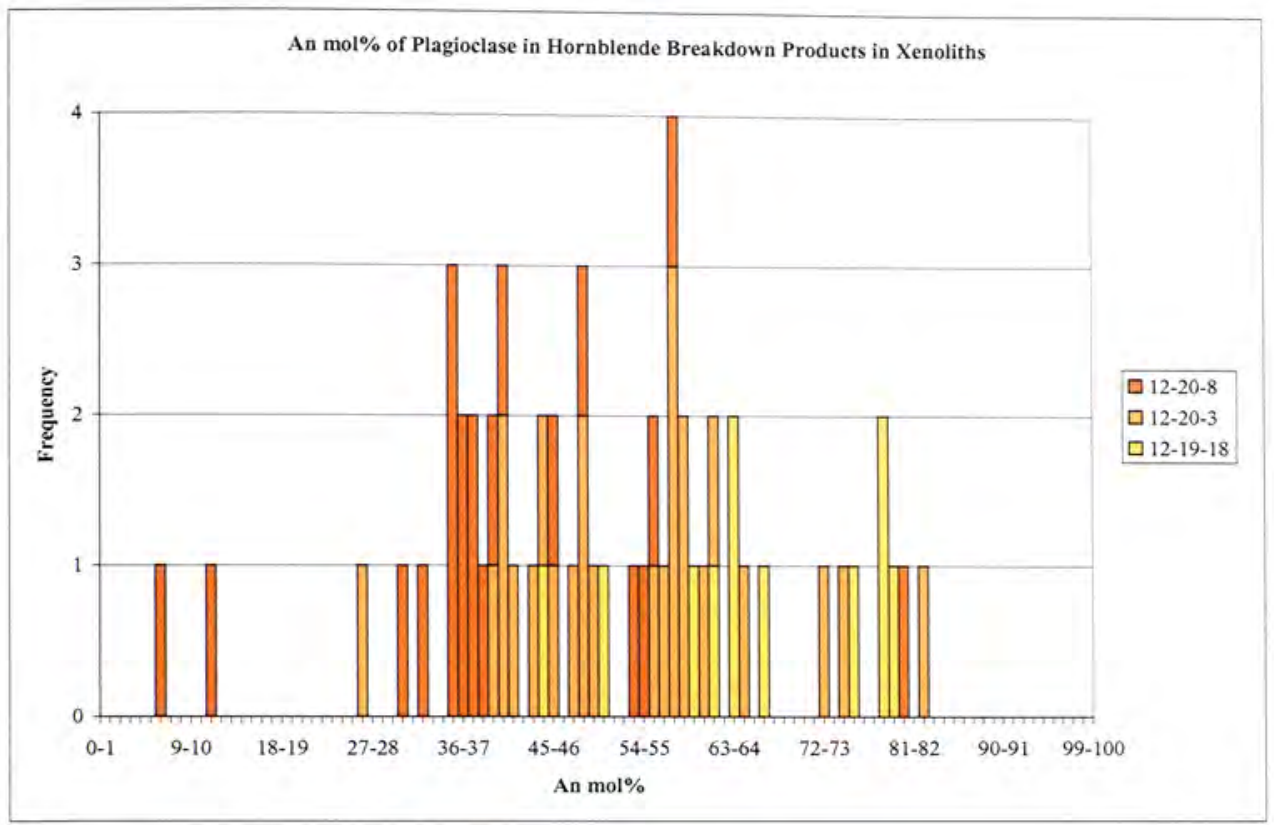

Figure 57: Histogram of plagioclase reaction products in gabbroic xenoliths. Histogram of frequency versus An mol\% of plagioclase in hornblende reaction products from breakdown of coarse grains in cumulate xenoliths.

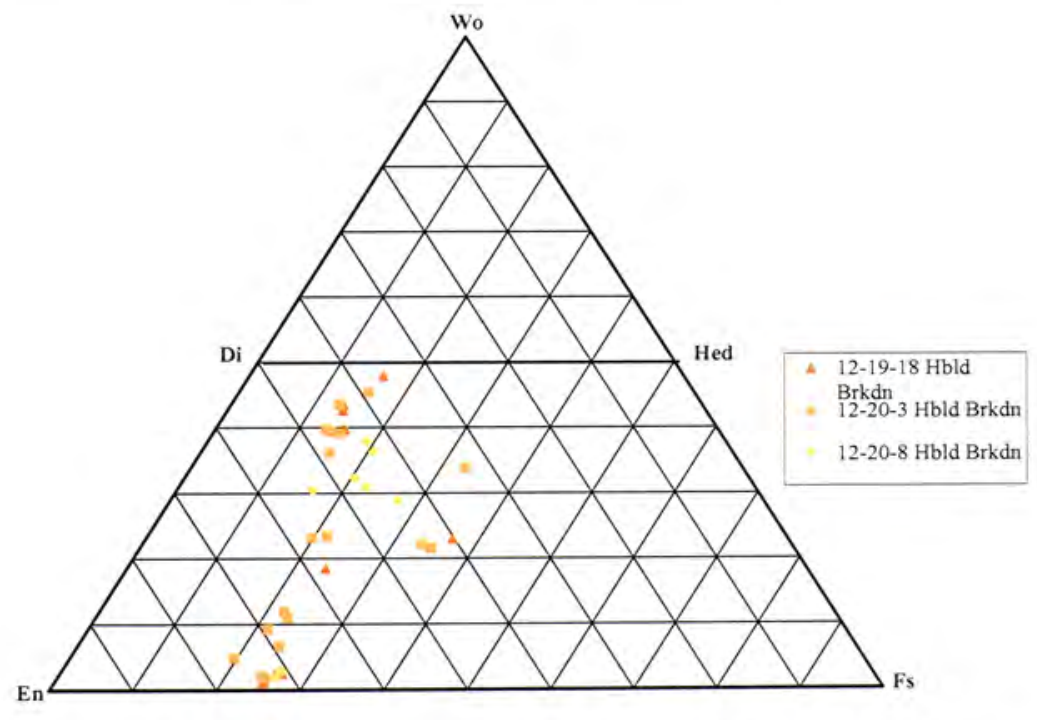

Figure 58: Ternary plot of pyroxene in gabbroic hornblende breakdown.

Ternary plot showing ortho- and clinopyroxene compositions in hornblende reaction products from breakdown of coarse grains in cumulate xenoliths. 


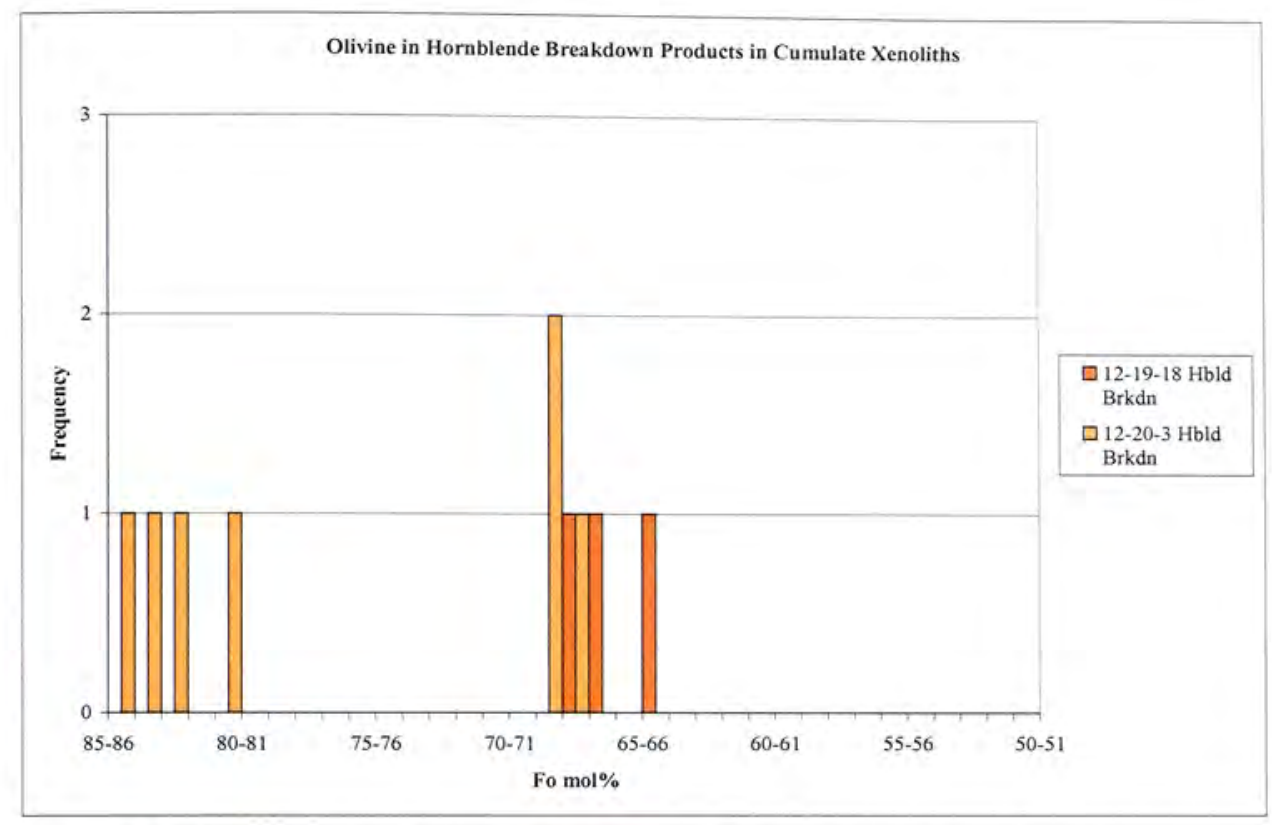

Figure 59: Histogram of olivine in gabbroic hornblende breakdown.

Histogram of frequency versus Fo mol\% of olivine in hornblende reaction products from breakdown of coarse grains in cumulate xenoliths.

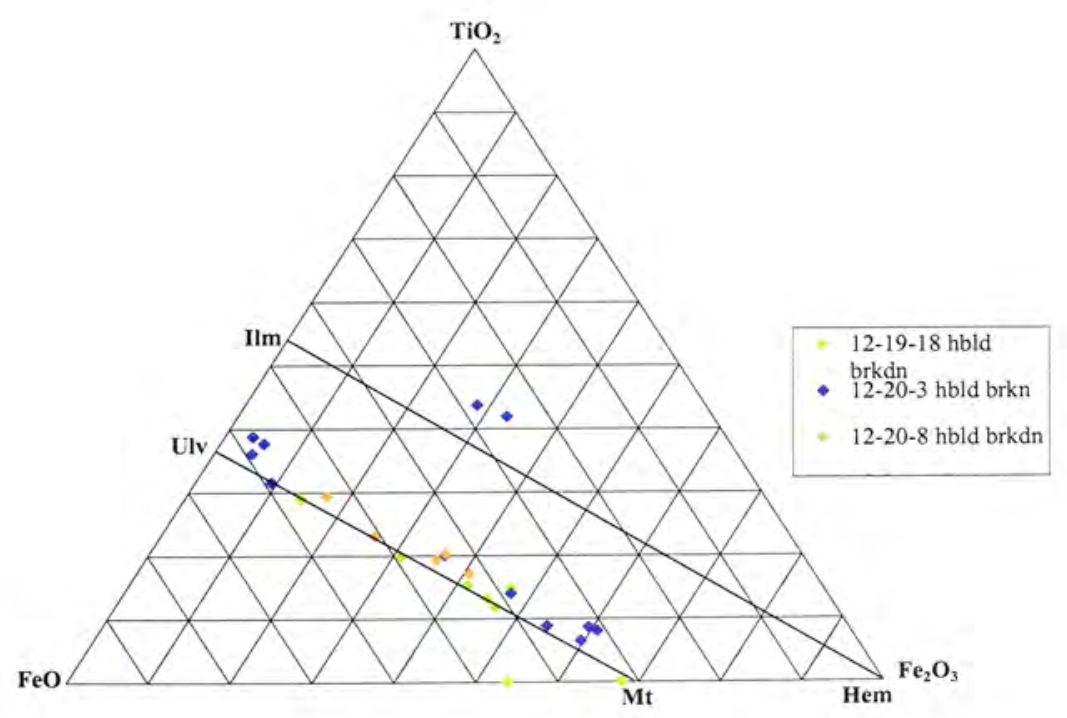

Figure 60: Ternary plot of oxides in gabbroic hornblende breakdown.

Ternary plot showing compositions of magnetite and ilmenite in hornblende reaction products from breakdown of coarse grains in cumulate xenoliths. 

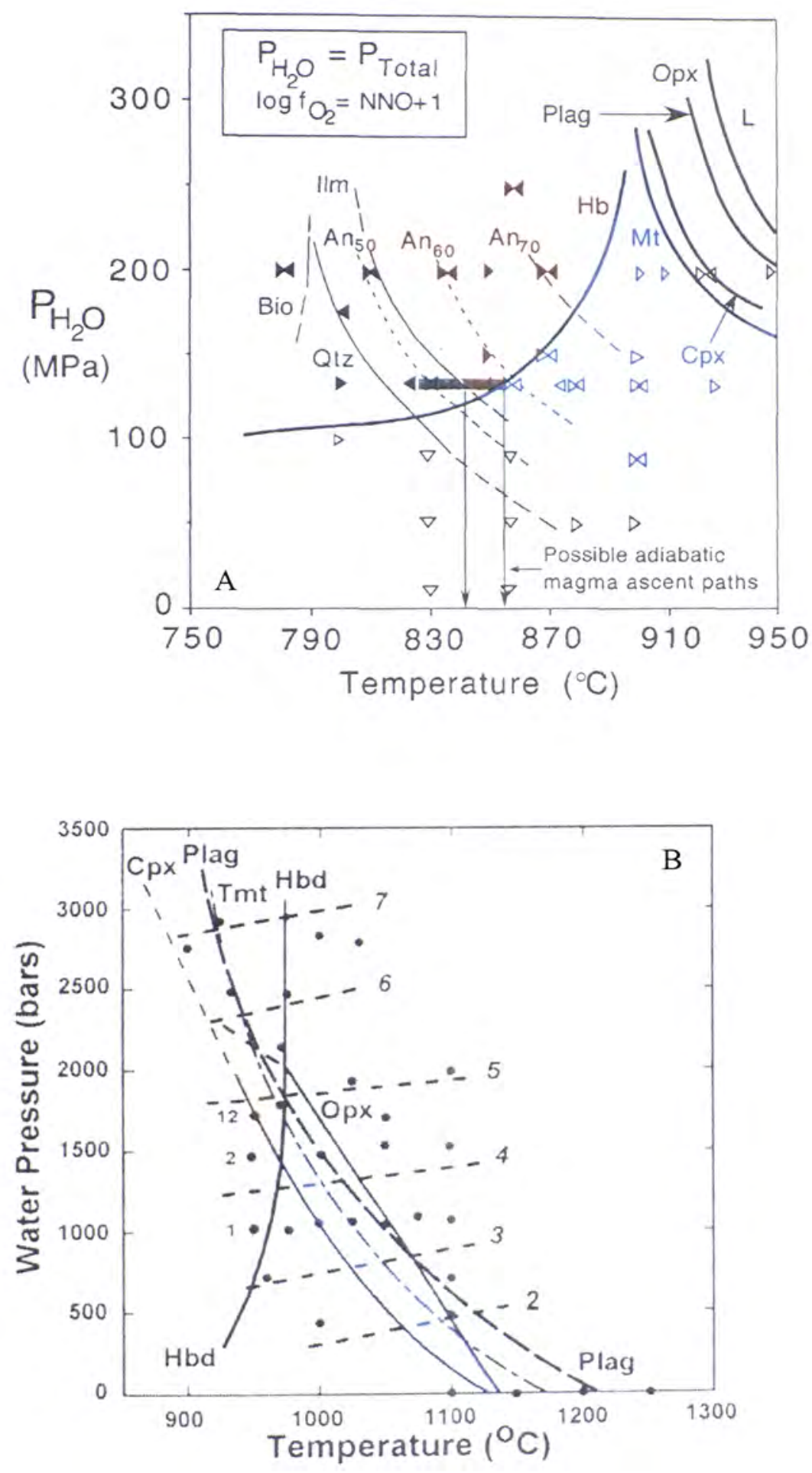


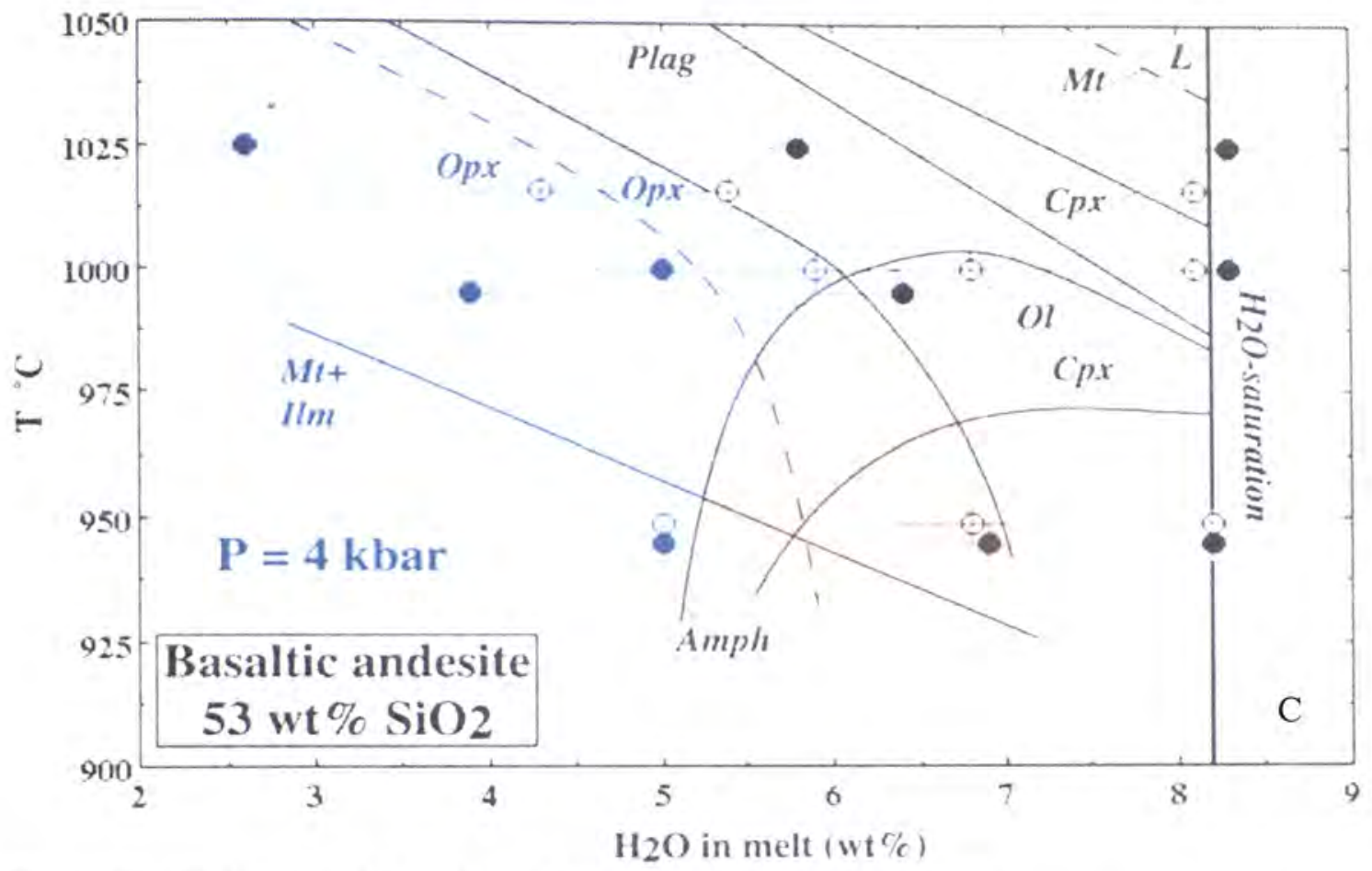

Figure 61: Andesite and basaltic andesite phase stability diagrams.

Phase diagrams showing stability of hornblende in andesite (A, B) and basaltic andesite (C). Orange and blue shaded areas on all three diagrams correspond to conditions under which Calbuco andesite (plagioclase + hornblende + magnetite + orthopyroxene \pm clinopyroxene \pm olivine) and basaltic andesite (plagioclase + olivine + orthopyroxene + olivine \pm clinopyroxene) would be stable respectively. A: (after Rutherford and Devine, 2003) shows the stable phases in Soufrière Hills andesite at water saturated conditions. Stability fields indicate first appearance with decreasing temperature. Triangles on the plot indicate experimental results from Rutherford and Devine (2003) for Soufrière Hills andesite and the black bar indicates pressure and temperature based on natural samples. B: (after Luhr, 2002), shows pressure versus temperature for Colima andesite under water saturated conditions with oxygen fugacity at the NNO buffer. Stability fields indicate first appearance with falling temperature. Filled black dots and corresponding numbers indicate experimental results from Luhr (2002), gray shaded area indicates the mineral assemblage from natural Colima samples, and slanted dashed lines represent the $\mathrm{wt} \%$ $\mathrm{H}_{2} \mathrm{O}$. C: (after Pichavant et al., 2002) for Mount Pelée basaltic andesite at water undersaturated conditions and oxygen fugacity variations of $\Delta \mathrm{NNO}<+1$ to $\Delta \mathrm{NNO}>+2.5$. Stability curves are labeled with mineral names inside their stability field. Circles on the diagram correspond to experimental results; open circles $\Delta \mathrm{NNO}<+1$ and closed circles $+1<\Delta \mathrm{NNO}<+1.5$ and $\Delta \mathrm{NNO}>+2.5$. Dashed lines for Opx and Mt stability fields correspond to $\triangle \mathrm{NNO}>+2.5$. These diagrams show that hornblende is stable below approximately $900-1000^{\circ} \mathrm{C}$, at pressures above approximately $0.5 \mathrm{kbar}$, and above $2-5 \mathrm{wt} \%$ water. 
Table 6: Calculated Pressure Range.

Table showing the calculated pressures of hornblende crystallization using a geobarometer based on the amount of $\mathrm{Al}$ in the crystal. Data for sample 12-18-1 from Abdollahi (1990). Calculations after Hammarstrom and Zen (1986).

\begin{tabular}{|c|c|c|c|c|c|c|c|c|c|c|c|c|c|c|}
\hline \multicolumn{15}{|c|}{ Ranges of Calculated Pressures (kbars) } \\
\hline \multicolumn{3}{|c|}{ Lava } & \multicolumn{12}{|c|}{ Cumulate Xenoliths } \\
\hline \multicolumn{3}{|c|}{ Calbuco-1 } & \multicolumn{3}{|c|}{$12-19-18$} & \multicolumn{3}{|c|}{$12-20-3$} & \multicolumn{3}{|c|}{$12-20-8$} & \multicolumn{3}{|c|}{$12-18-1$} \\
\hline 7.7 & 6.8 & 8.0 & 7.4 & 6.5 & 7.3 & 8.8 & 8.2 & 10.9 & 7.7 & 6.9 & 8.0 & 8.3 & 7.6 & 9.5 \\
\hline 7.0 & 6.0 & 6.4 & 5.1 & 4.1 & 3.7 & 4.5 & 3.6 & 3.1 & 4.5 & 3.6 & 3.1 & 4.7 & 3.8 & 3.3 \\
\hline
\end{tabular}

Table 7: $\mathrm{Cr}_{2} \mathrm{O}_{3} \mathrm{wt} \%$ comparison of hornblende and phlogopite.

Table comparing the $\mathrm{Cr}_{2} \mathrm{O}_{3}$ wt\% and $\mathrm{Mg}$-number of hornblende and phlogopite and $\mathrm{Na}_{2} \mathrm{O}$ wt $\%$ of phlogopite in gabbroic xenoliths reported by Costa et al. (2002) with that found at Calbuco.

\begin{tabular}{|c|c|c|c|c|}
\hline \multicolumn{5}{|c|}{$\begin{array}{c}\text { Comparison of } \mathrm{Cr}_{2} \mathrm{O}_{3} \text { wt } \% \text { and Mg-number of Hornblende and Phlogopite and } \mathrm{Na}_{2} \mathrm{O} \text { wt } \% \text { of Phlogopite } \\
\text { From Calbuco with Values From Volcán San Pedro }\end{array}$} \\
\hline \multicolumn{5}{|c|}{ Hornblende } \\
\hline & \multicolumn{2}{|r|}{ Calbuco } & \multicolumn{2}{|c|}{ Volcán San Pedro (Costa et al., 2002) } \\
\hline & $\begin{array}{l}\text { Gabbroic } \\
\text { Average }\end{array}$ & Group 1 & $\begin{array}{c}\text { Group 2 } \\
\text { (w/hornblende) }\end{array}$ & $\begin{array}{c}\text { Group } 2 \\
\text { (w/clinopyroxene) }\end{array}$ \\
\hline $\mathrm{Cr}_{2} \mathrm{O}_{3} \mathrm{wt} \%$ & $0.002-0.08$ & $\leq 1.2$ & $\leq 0.6$ & $\leq 0.6$ \\
\hline$M g \#$ & $65-71$ & $72-80$ & $72-80$ & $64-77$ \\
\hline \multicolumn{5}{|c|}{ Phlogopite } \\
\hline $\mathrm{Cr}_{2} \mathrm{O}_{3} \mathrm{wt} \%$ & 0.02 & $\leq 0.6$ & $\leq 0.4$ & $\leq 0.4$ \\
\hline$M g \#$ & $77-79$ & $77-82$ & $77-84$ & $70-80$ \\
\hline $\mathrm{Na}_{2} \mathrm{O} w t \%$ & $1.34-1.94$ & $2.21-3.36$ & $1.94-4.08$ & $1.13-1.92$ \\
\hline
\end{tabular}




\section{Chapter 6. Plagioclase}

\subsection{Introduction}

Plagioclase is a major igneous mineral phase found in arc settings, and in rocks across the compositional range from basalt to rhyolite, and because of this abundance, is widely studied. This chapter deals with the texture and chemistry of the plagioclase crystal populations found both in Calbuco andesite and basaltic andesite. Topics of discussion include plagioclase zoning, including major, minor, and trace element zoning, along with the types of zoning present in phenocrysts from Calbuco. Controls on trace element incorporation into the plagioclase crystal structure are also discussed. Additionally, plagioclase resorption surfaces, textures, and events are discussed. The chemical composition of volcanic glass trapped within plagioclase grains is also discussed.

\subsection{Crystal Populations and Textural Descriptions}

There are five different plagioclase crystal populations in the eruptive products of Calbuco Volcano. These are: 1) megacrysts, 2) phenocrysts, 3) plagioclase in the cumulate gabbronorite xenoliths, 4) plagioclase in the crystal clusters, and 5) plagioclase formed as a result of hornblende breaking down. Of these five populations, all are found in andesitic samples and only megacrysts, phenocrysts, and plagioclase in the crystal clusters are found in basaltic andesite.

\section{2a Megacrysts}

Plagioclase megacrysts are 1600 microns and larger in size and found in both the andesite and basaltic andesite samples (Figure 62). In both rock types, these crystals are euhedral to subhedral and have no noticeable melt inclusions or resorption features in the 
core; resorption features may be present in the thicker zoned rims. Plagioclase megacrysts have an unzoned core with a very high $\mathrm{An}$ mol\%, ranging from $\mathrm{An}_{87-92}$ in the andesite, with one grain as low as $\mathrm{An}_{83}$, and $\mathrm{An}_{90}$ in the basaltic andesite. Progressing outward from the core, these grains have zoned rims of thicknesses varying from 20-130 microns in the andesite, with two that have thick rims of 180-390 microns, and 200 microns in the basaltic andesite. The zoned rims have a lower An mol\% than the cores; $\mathrm{An}_{49-85}$ in the andesite and $\mathrm{An}_{65-79}$ in the basaltic andesite (Figure 63) (complete electron microprobe data and transect plots of all plagioclase can be found in appendix D).

\section{$6.2 b$ Phenocrysts}

Plagioclase phenocrysts are 1500 microns and smaller in size and found in both the andesite and basaltic andesite. There was not a separate compositional study done of the phenocrysts and microphenocrysts, therefore this group also includes microphenocrysts. The subcategory of microphenocrysts, encompassing approximately $30 \%$ of the plagioclase crystals, includes crystals $0.13 \mathrm{~mm}$ and less in size and will hereafter be included in the phenocryst crystal population. The phenocrysts are euhedral to anhedral and a small percentage are sieve textured. Phenocrysts in both the andesite and basaltic andesite are complexly zoned (Figure 64) with core An compositions that are lower than the core composition of the megacrysts, ranging from $\mathrm{An}_{58-92}$ in the andesitic samples and $\mathrm{An}_{73-90}$ in the basaltic andesite (Figure 65). The phenocryst rims range compositionally from $\mathrm{An}_{35-84}$ in the andesites and $\mathrm{An}_{48-86}$ in the basaltic andesites (complete electron microprobe data and transect plots of all plagioclase can be found in appendix D). The majority of these crystals have normal zoning with overprinted oscillatory zoning. There are a few reverse-oscillatory zoned crystals; however, the 
occurrence is rare. Some crystals also have patchy zoning. Point counting of a representative andesitic lava sample from the Calbuco 4 unit (Table 8) demonstrates that approximately $36 \%$ of these crystals are euhedral and $64 \%$ are anhedral. Many of these grains contain melt inclusions, and an average of $26 \%$ of these inclusions are confined within specific compositional zones within the grain.

\section{$6.2 c$ Cumulate Xenoliths}

Plagioclase in the three cumulate gabbronorite xenoliths is predominantly unzoned, although there are a few grains found which do show a small amount of zoning. One transect was taken of a slightly zoned grain, ranging from $\mathrm{An}_{86}$ at the core to $\mathrm{An}_{79}$ at the rim (Figure 66). Compositionally, these plagioclase grains range from $\mathrm{An}_{90-93}$, with one highly calcic grain of $\mathrm{An}_{97}$, in sample 12-19-18, $\mathrm{An}_{70-93}$, with two less calcic grains ranging from $\mathrm{An}_{56-64}$, in sample 12-20-3, and $\mathrm{An}_{73-92}$ in sample 12-20-8 (complete electron microprobe data of all plagioclase can be found in appendix D). Among the three gabbronorite samples studied, the plagioclase is found in varying stages of stability. The plagioclase is decomposing accompanied by decompression melting of the hornblende in the xenoliths. In sample 12-19-18 the plagioclase is euhedral to anhedral and poikilitically enclosed in one hornblende grain which is enclosing all mineral phases in the thin section. Plagioclase decomposition in this sample is slight, as is the hornblende breakdown (Figure 67). Similarly, the plagioclase decomposition in sample $12-20-8$ is slight, although the hornblende in this sample is more broken down than in sample 12-19-18. Plagioclase grains in this sample are predominantly anhedral and breakdown reactions in the xenolith are taking place between the plagioclase grains (Figure 68). In contrast, the plagioclase in sample 12-20-3 is extremely decomposed 
(Figure 69). Hornblende in this sample, along with all other mineral phases, has broken down the most extensively of the three samples. The entire xenolith has a metamorphic texture (detailed in chapter 4) and the plagioclase is microcrystalline and sometimes spongy with patches of glass.

\section{2d Crystal Clusters}

Crystal clusters are found in both andesite and basaltic andesite samples. These clusters have been grouped into six different categories based on their mineral assemblage, and are discussed in detail in chapter 4. All six of these categories contain euhedral to anhedral plagioclase, most of which is unzoned, however some zoned crystals are incorporated. Plagioclase in type $\mathrm{A} 1$ clusters ranges from $\mathrm{An}_{42-91}$, and in type $\mathrm{A} 2$ clusters ranges from $\mathrm{An}_{90-91}$ with one less calcic crystal at $\mathrm{An}_{61}$. Type $\mathrm{B} 1$ clusters have plagioclase grains which range from $\mathrm{An}_{67-76}$, with one highly calcic grain of $A n_{91}$. Type $\mathrm{B} 2$ crystal clusters have plagioclase which range compositionally from $\mathrm{An}_{64-91}$. Types $\mathrm{C}$ and $\mathrm{D}$ clusters have plagioclase which ranges from $\mathrm{An}_{84-92}$ and $\mathrm{An}_{87-90}$ respectively (complete electron microprobe data of all plagioclase can be found in appendix D).

\section{2e Hornblende Breakdown Product}

Plagioclase is found among the products of hornblende breakdown. These grains are microcrystalline, ranging in size from approximately $<5$ microns, and compositionally range from $\mathrm{An}_{7-83}$. This plagioclase population is discussed in detail in chapter 5 .

\subsection{Zoning}

It has been stated that plagioclase zoning is a stratigraphic record of the magmatic events which occur during crystallization (Singer and Pearce, 1993; Vance, 1962). Plagioclase zonation is caused by elemental variations in the magma as the crystal is 
growing, specifically variations of $\mathrm{Ca}$ and $\mathrm{Na}$. Plagioclase solid solution ranges from anorthite $(\mathrm{An})$, the Ca-rich, high temperature end member to albite $(\mathrm{Ab})$, the Na-rich, lower temperature end member. Plagioclase zoning is manifested in the mineral grain as the variation of anorthite (An) mol\%. Due to the coupled substitution described by Grove et al. (1984) of NaSi for CaAl into the plagioclase crystal structure, major element diffusion is extremely slow and An zoning, once the closure temperature of crystallization has been reached, will remain essentially unchanged under most geologic circumstances (Costa et a1., 2003). Due to this "freezing" of An zoning, individual plagioclase zones can be expected to preserve a record of the conditions inside the magma chamber at the time of crystal formation.

Several different types of zoning are common in plagioclase, but the main types found in the samples from Calbuco are normal zoning, reverse zoning, and oscillatory zoning; minor patchy zoning is also found. Normally zoned crystals have a more An rich core with a progressively more Ab rich rim. Reverse zoning is the opposite of normal zoning, the core has a higher $\mathrm{Ab} \mathrm{mol} \%$ and the rim a higher $\mathrm{An}$ mol\%. Oscillatory zoning is the result of oscillations of An mol\% between a normal and a reverse trend. Although the term "oscillatory" is used to describe this type of zoning, Shore and Fowler (1996) point out that the oscillations in both zone thickness and composition are not necessarily harmonic or regular. Shelly (1993) describes three types of oscillatory zoning, major sharp reversals, small irregular oscillations, and complex oscillatory zoning. The major sharp reversals are large An mol\% spikes followed by normal zonation. Small irregular oscillations are small reversals between normal and reverse zoning. Complex oscillatory zoning is a combination of major sharp reversals and small 
irregular oscillations. Patchy zoning (pictured in Figure 81) is a mixture of remnant plagioclase, representing the outermost zone of the crystal prior to resorption, and plagioclase grown during or immediately after the resorption event (Ginibre et al., 2002b).

The An mol\% of the plagioclase can be affected by several different factors which influence magma and plagioclase compositions. These factors include magma mixing, stratification of the magma chamber, phenocryst recycling, tidally-driven circulation within the magma chamber, plagioclase resorption during magma ascent (Singer and Pearce, 1993), the dissolved water content of the magma, magma storage depth (Singer et al., 1995 and Holten et al., 1997), crystallization kinetics due to fluctuations in $\mathrm{Ca}$ and $\mathrm{Na}$ in the magma immediately surrounding the crystal during growth, magmatic temperature and pressure, decompression, and crystal growth rate (Singer et al., 1995 and Holten et al., 1997). Many authors link recorded An mol\% variations to one or more of these factors to demonstrate specific magmatic process or group of processes at work in the volcanic system studied (examples include Nixon and Pearce, 1987; Stewart and Fowler, 2001; Bottinga et al., 1966; Hattori and Sato, 1996; Stamatelopoulou-Seymour et al., 1990; Kuritani, 1998; Blundy and Shimizu, 1991; Ginibre et al., 2004; Ginibre et al., 2002a,b; Singer et al., 1995; Karsli et al., 2004).

\section{3a Major Element Zoning}

Plagioclase crystals found in most of the eruptive products from Calbuco Volcano display complex zoning patterns. Major element concentrations of plagioclase crystals have been determined using the electron microprobe, which has an analytical error of better than $\pm 1 \mathrm{An}$ mol\% (Sen, personal communication). Electron microprobe transects 
(appendix D) reveal that the plagioclase megacrysts are all normally zoned. With the exception of one megacryst, which exhibits oscillatory zoning over the entire crystal, all of these grains have an unzoned core with normally zoned rims of varying thickness. These rims have varying degrees of fine scale oscillations overprinted on the normal zoning. The zoning oscillates over a range of 1-10 An mol\% (Figure 70). The one megacryst which is completely zoned is found in the andesitic lava and ranges core to rim from $\mathrm{An}_{57-83}$. The oscillations fluctuate over a range of $0.5-14 \mathrm{~mol} \%$ An (Figure 71 ). In the basaltic andesite plagioclase, zoning oscillates over a range of 1-10 An mol\% (Figure 72).

Electron microprobe transects taken of the phenocrysts in both the andesite and basaltic andesite samples show that they are predominantly normally zoned (Figure 73), except for nine crystals which are reversely zoned (Figure 75), seven of which are found in the andesitic lava and two in the basaltic andesite lava. Both the normally zoned and reversely zoned plagioclase grains have fine scale oscillatory zoning overprinting the overall normal or reverse zonation trend. This fine scale oscillatory zoning is discussed in section $6.2 \mathrm{~d}$. The plagioclase found in the gabbronorite xenoliths and clusters within the lava are predominantly unzoned, with only a few slightly zoned crystals. Detailed transects have not been taken of the slightly zoned crystals in the xenoliths or clusters. The plagioclase in the hornblende breakdown product is not zoned.

\section{3b Minor and Trace Element Zoning}

Trace element contents of $\mathrm{Fe}, \mathrm{Ti}, \mathrm{Mg}, \mathrm{Sr}$, and $\mathrm{Ba}$ in plagioclase were measured by electron microprobe transects taken from core to rim over the zoned portions of the megacrysts and phenocrysts within both the andesite and basaltic andesite samples 
(appendix D). Detection limits for these elements on the electron microprobe are approximately $500 \mathrm{ppm}$ at short count times (Beasley, personal communication). Concentrations of $\mathrm{Ba}$ are completely below the detection limit of the microprobe under the operating conditions chosen and will not be considered further. Sr concentrations are below microprobe detection limits at low count times but can be detected at higher count times, therefore there are a limited number of $\mathrm{Sr}$ transects. Ti concentrations are variable at low count times but detectable at higher count times and are also only reported for a limited number of transects. In contrast, concentrations of $\mathrm{Fe}$ and to a lesser extent $\mathrm{Mg}$ are detectable at both low and high count times (Figure 76). The analytical error of the electron microprobe is taken to be $\pm 100 \mathrm{ppm}$ of the elemental concentration (Beasley, personal communication). The transects show that there is also trace element zoning in the plagioclase phenocrysts and megacrysts. However, in accord with the findings of Ginibre et al. (2002b) on plagioclase in lavas from Parinacota Volcano in Northern Chile, the fine-scale oscillations seen in the major element zoning are not duplicated in the trace element zoning.

Attempting to uniquely discriminate between some of the previously discussed factors which cause An mol\% variations (see section 6.2) solely based on binary compositional variation (i.e. Ca and Na variations) may be difficult (Singer et al., 1995). Singer et al. (1995), Ginibre et al. (2002b), and others have found that, in addition to the variation in $\mathrm{An} \mathrm{mol} \%$, it was necessary to examine variations in minor and trace elements, such as $\mathrm{Fe}, \mathrm{Mg}$, $\mathrm{Ti}$, which are incompatible elements in plagioclase, and $\mathrm{Sr}$, which is a compatible element. Since these elements are not inherent to the plagioclase crystal structure, their variations within the mineral are a function of the partition 
coefficient for each element between the mineral and the melt. As a result of this, Singer et al. (1995) concluded that studying the variations in minor and trace elements along with An mol\% variation could help to distinguish between magmatic processes responsible for plagioclase zoning. Each trace element can be used to recognize different magmatic processes due to element-specific factors affecting partition coefficients. 6.3b.i Fe

Details of the incorporation of Fe into plagioclase have been widely published, including Singer et al. (1995), Ginibre et al. (2002b), Bindeman et al. (1998), Longhi et al. (1976), Phinney (1992), Sugawara (2001), Sato (1989), and Wilke and Behrens (1999). According to Bindeman et al. (1998), as Fe is incorporated into plagioclase, there is a strong negative correlation with An content (Figure 77a). Ginibre et al. (2002b) and Sugawara (2001) have suggested that the negative correlation with An content is actually a negative correlation with temperature. Looking separately at both species of iron, ferrous and ferric, ferrous iron $\left(\mathrm{Fe}^{2+}\right)$ will be incorporated into either octahedral (M) or tetrahedral $(\mathrm{T})$ sites in the crystal lattice (Sugawara, 2001), substituting for $\mathrm{Ca}$ in the $\mathrm{M}$ sites and $\mathrm{Al}$ in the $\mathrm{T}$ sites (Wilke and Behrens, 1999). Ferric iron $\left(\mathrm{Fe}^{3+}\right)$ is the preferred species of iron in plagioclase and is incorporated into $\mathrm{T}$ sites replacing $\mathrm{Al}$ (Sugawara, 2001). Partitioning of $\mathrm{Fe}$ into plagioclase is extremely sensitive to oxygen fugacity $\left(f \mathrm{O}_{2}\right)$ (Sugawara, 2001; Bindeman et al., 1998; Ginibre et al., 2002b; Longhi et al., 1976; Sato, 1989; Phinney, 1992; Wilke and Behrens, 1999) due to an increase in the partition coefficient with increasing oxygen fugacity (Sugawara, 2001). An increase in $f \mathrm{O}_{2}$ will increase $\mathrm{Fe}^{3+} / \mathrm{Fe}^{\mathrm{t}}$, and therefore increase the $\mathrm{Fe}$ content of the plagioclase. Since $\mathrm{Fe}^{3+}$ is the dominant iron species in plagioclase, it will be assumed that the behavior of total iron 
$\left(\mathrm{Fe}^{\mathrm{t}}\right)$ in plagioclase is equivalent to the behavior of $\mathrm{Fe}^{3+}$. For simplification, total iron $\left(\mathrm{Fe}^{\mathrm{t}}\right.$ ) will be discussed as iron (Fe). According to Longhi et al. (1976), temperature is not likely to have an effect on the partition coefficient for Fe between plagioclase and liquid. They have reported partition coefficients ranging from $0.058 \pm 0.008$ to $0.18 \pm 0.02$ for plagioclase in basalt. For intermediate rock compositions under water saturated conditions at 5 kbar pressure, Wilke and Behrens (1999) have reported partition coefficients ranging from $0.085-0.66$ and $0.099-0.791$.

In agreement with Bindeman et al., (1998), there is an overall negative correlation between $\mathrm{An}$ mol\% and $\mathrm{Fe}$ concentration for plagioclase in both Calbuco andesite and basaltic andesite (Figure 78). However, within transects of individual plagioclase grains (Figure 79), sharp increases (spikes) in An mol\% tend to be accompanied by an increase in Fe concentration in the plagioclase in the andesite. The plagioclase in the basaltic andesite (Figure 80) showed a similar trend of Fe enrichment and depletion with An spikes. Considering only this trace element, an increase in Fe concentration alone could indicate an increase in $f \mathrm{O}_{2}$ of the magma or mixing with a $\mathrm{Ca}$ and Fe rich magma. Since An $\mathrm{mol} \%$ of the plagioclase is not directly affected by $f \mathrm{O}_{2}$, another accompanying parameter, such as high $f \mathrm{H}_{2} \mathrm{O}$, would be necessary to explain the correlated high $\mathrm{Ca}+\mathrm{Fe}$.

\section{3b.ii Mg}

$\mathrm{Mg}$ partitioning between plagioclase and melt is complex. According to Bindeman et al. (1998) and Ginibre et al. (2002b), there is only a very weak negative correlation between $\mathrm{Mg}$ content and An content (Figure 77b). Longhi et al. (1976) and Ginibre et al. (2002b) report a small temperature dependence on $\mathrm{Mg}$ incorporation into plagioclase, with changes needing to be on the order of several hundred degrees in order 
to vary the Mg partitioning (Singer et al., 1995). Sato (1989) reported no correlation between $\mathrm{Mg}$ content and oxygen fugacity. The complexity of $\mathrm{Mg}$ partitioning into plagioclase can be expected due to sensitivity to pressure, melt composition, or splitting between M and T sites in the crystal structure (Bindeman et al., 1998). Sugawara (2001) report the possibility of $\mathrm{Mg}$ substituting for either $\mathrm{Ca}$ in the $\mathrm{M}$ site or $\mathrm{Al}$ in the $\mathrm{T}$ site. Peters et al. (1995) show a positive correlation between the partition coefficient for $\mathrm{Mg}$ and the activity ratio of $\left[\mathrm{SiO}_{2}\right]_{\mathrm{L}} /\left[\mathrm{Al}_{2} \mathrm{O}_{3}\right]_{\mathrm{L}}$ meaning an increase in $\mathrm{Mg}$ content in plagioclase as the magma differentiates.

The $\mathrm{Mg}$ concentration of plagioclase in andesite and basaltic andesite from Calbuco has an overall negative correlation with An mol\% (Figure 78), however this correlation is not as weak as the correlation between $\mathrm{Mg}$ and $\mathrm{An}$ mol\% found by Bindeman et al. (1998). Within individual plagioclase transects, An spikes are usually accompanied by a decrease in $\mathrm{Mg}$ concentration in plagioclase in both andesite and basaltic andesite (Figure 79, Figure 80). Considering only $\mathrm{Mg}$, the decreased concentration with An spikes could be due to the increase in An mol\% (partitioning effects) or due to mixing with a Ca-rich, Mg-poor magma or an $\mathrm{H}_{2} \mathrm{O}$ rich, Mg-poor magma (Table 9).

\section{3b.iii Ti}

Ti has a strong negative correlation with An content (Figure 77c), however, based on calculations of temperature dependency, the correlation is seemingly independent of temperature (Bindeman et al., 1998; Ginibre et al., 2002b). Peters et al. (1995) concluded that $\mathrm{Ti}$ partitioning into plagioclase is dependant on magma composition and small compositional variations in the liquid could cause large changes in the partition 
coefficient for $\mathrm{Ti}$. Ti is incorporated into the crystal structure in a $\mathrm{T}$ site, substituting for Si (Peters et al., 1995).

The relationship between $\mathrm{Ti}$ and An content of plagioclase in Calbuco andesite and basaltic andesite is negatively correlated (Figure 78). Within transects of individual plagioclase grains in the andesite, there is not a strong tendency for Ti to either increase or decrease with An spikes (Figure 79). On the contrary, in basaltic andesite (Figure 80), there is a tendency for $\mathrm{Ti}$ to decrease with An spikes in plagioclase transects. Considering only $\mathrm{Ti}$, a decrease in $\mathrm{Ti}$ concentration correlated with increases in $\mathrm{An}$ mol\% could be due to the existing negative correlation between An mol\% (partitioning effects) and $\mathrm{Ti}$ concentration, or could be the result of magma mixing with a $\mathrm{Ca}$ rich, Ti poor magma or an $\mathrm{H}_{2} \mathrm{O}$ rich, Ti-poor magma.

\section{3b.iv $\mathrm{Sr}$}

Based on the findings of several people, including Blundy and Wood (1991), Bindeman et al. (1998), and Ginibre et al. (2002b), the controlling factor for $\mathrm{Sr}$ partitioning into plagioclase is the composition of the plagioclase. Sr has a negative correlation with An content (Figure 77d), and fills a crystallographic M site, substituting for Na (Blundy and Wood, 1991). Previous conclusions have shown that pressure at shallow crustal depths, melt composition, temperature, and crystallographic defects within the plagioclase grain do not have an effect on the partitioning of $\mathrm{Sr}$ (Blundy and Wood, 1991).

Sr in plagioclase in Calbuco andesites and basaltic andesites has no clearly defined correlation with An mol\% (Figure 78). This is likely the result of low $\mathrm{Sr}$ concentrations in the plagioclase close to the detection limit of the microprobe. Sr is 
compatible in the plagioclase crystal structure and partition coefficients $\left(\mathrm{Sr}_{\text {plag }} / \mathrm{Sr}_{\text {melt }}\right)$ should range from 1-2 (Hickey-Vargas, personal communication), however the range for $\mathrm{Sr}$ in plagioclase in Calbuco andesite is 0.9-2.5 and in basaltic andesite is 0.8-3.5. This indicates that individual compositional zones may vary in stability in the magma and may indicate mixing with a magma of different $\mathrm{Sr}$ compositions. Within transects of individual plagioclase grains (Figure 79, Figure 80), Sr tends to decrease with An spikes in the plagioclase in the basaltic andesite but a trend is not discernable in the andesitic plagioclase. Decreases in Sr concentration with increases in An mol\% could be due to $\mathrm{Sr}$ tendency to substitute for $\mathrm{Na}$ in the plagioclase crystal structure or could reflect mixing with a $\mathrm{Ca}$ rich, $\mathrm{Sr}$ poor magma or an $\mathrm{H}_{2} \mathrm{O}$ rich, Sr poor magma.

\section{3c Plagioclase Resorption}

As magmatic conditions fluctuate inside a magma chamber, plagioclase crystals may circulate through magma having higher An content. As the crystal comes in contact with magma that has a composition different from the liquid in equilibrium with the outside crystal zone, resorption, or dissolution, of the plagioclase occurs because the crystal is no longer stable in the surrounding magma. Magmatic processes which can cause resorption of plagioclase are 1) increased temperature due to magma mixing with a hotter, more mafic magma, magma recharge, or convection within a temperature gradient, 2) an increase in the wt $\%$ of dissolved water in the magma due to mixing with a hydrous melt or convection within a water gradient. The $\mathrm{H}_{2} \mathrm{O}$ content of the magma may also be affected by crustal contamination, but the effect of this would be recorded in plagioclase on a local scale. Distinguishing petrographically between increased 
temperature and increased $\mathrm{H}_{2} \mathrm{O}$ wt $\%$ is not possible. To make this distinction, trace element fluctuations can be used.

\section{3c.i Resorption Textures}

Sieve textured plagioclase and patchy zoning (Figure 81) are two of the resorption textures preserved in the plagioclase from Calbuco Volcano. Patchy zoning has been interpreted by Ginibre et al. (2002b) to be the result of simultaneous dissolution of the outermost existing zone and crystallization of a higher An zone. Some of the sieve textured grains have glass preserved along with the resorption surface, and some have holes which may have contained glass which was polished out at the time the slide was made. As a result of point counting done on representative plagioclase phenocrysts to determine resorption patterns (Table 8 ), approximately $21 \%$ of the phenocrysts have resorption with preserved glass within a particular crystal growth zone (Figure 82).

\section{3c.ii Resorption Surfaces}

Distinguishable resorption surfaces are found in plagioclase phenocrysts and the outer zones of some of the megacrysts and have been categorized as major and minor resorption surfaces. Major resorption surfaces $(\mathrm{R})$ are resorption events which visibly cut across more than one zone (Figure 83). Minor resorption surfaces (r) cut across only one zone (Figure 84). Textural analysis of resorption surfaces for my samples has only been possible using the petrographic microscope. Due to this, identification of these surfaces has only been done on samples with thin sections which could be used on the electron microprobe (see chapter 3 for details of analysis). Published work has shown that these surfaces can be characterized using high-resolution back scattered imaging (Ginibre et al., 2002b). In this work, plagioclase zones as thin as approximately 1 micron could be 
imaged quite clearly, however, the resolution of the microprobe used for my samples was not as high and the smallest zones clearly imaged are approximately 12 microns. Transects were also taken on plagioclase in the thick rock chips; resorption surfaces can not been seen, chemical variations can be analyzed.

Minor resorption surfaces are characterized by rounded corners on a particular zone, pinching out of a zone, rough surfaces instead of planar, and are sometimes not well pronounced in the crystal. This type of resorption occurs both with and without patchy zoning. Minor resorption surfaces are also found with and without glass/inclusions, varying from small to quite large, and are typically found in the interior of the grain (Figure 84). Major resorption surfaces are typically found near the rim of the grain. This type of resorption is typically found in conjunction with patchy zoning and glass/inclusions. The glass/inclusions found are both large and small in size (Figure 83). Details of the resorption surfaces of individual plagioclase crystals studied are in appendix D.

\section{3d Plagioclase Growth Zones}

The interior portion of the crystal between resorption surfaces has been labeled as a "growth zone" (Figure 85). Within these growth zones, both normal and reverse zoning occur with finer-scale oscillations overprinted. Three types of oscillatory zoning have been identified, labeled type 1 , type 2 , and type 3 . Type 1 oscillatory zoning has An fluctuations up to $2 \mathrm{~mol} \%$ with no visible resorption surfaces similar to the lowamplitude oscillations reported by Ginibre et al. (2002b). Type 2 oscillatory zoning has An fluctuations ranging from approximately 2-5 mol\% and occur without visible resorption surfaces. Type 3 oscillatory zoning has An fluctuations typically as high as 10 
mol\%, with a few sudden sharp increases (spikes) fluctuating higher, and are typically following visible resorption surfaces. These visible resorption surfaces can be either major or minor resorption surfaces. Both types of resorption surfaces are followed immediately by spikes in An content. Minor resorption surfaces are followed by An spikes ranging from $5-10 \mathrm{~mol} \%$ and higher, and major resorption surfaces are followed by An spikes ranging from 3-10 mol\%. An example of this can be found in Figure 85 . Some crystals have abrupt An drops within a growth zone or at the rim ranging from approximately $12-24 \mathrm{~mol} \%$ in the interior of the crystal and approximately $37 \%$ at the crystal rim (Figure 85).

\subsection{Chemical Composition of Glass Found in Plagioclase}

Quenched glass is found in three of the different plagioclase populations: plagioclase phenocrysts, plagioclase in crystal clusters, and plagioclase in cumulate xenoliths. The glass in all three plagioclase populations is clear and brown varying from a medium brown to deep brown. In the phenocrysts, glass is typically found oriented randomly; however, a few grains do have glass trapped within a specific zone (Figure 82). Analysis was done of the glass in plagioclase phenocrysts in one representative sample. The compositional range of the glass is dacitic to rhyolitic (65-74 wt $\left.\% \mathrm{SiO}_{2}\right)$. (This same $\mathrm{SiO}_{2}$ range is also represented in numerous glass inclusions confined within a single plagioclase crystal (dacitic to rhyolitic, $\left.65-74 \mathrm{wt} \% \mathrm{SiO}_{2}\right)$ ). Glass contained in the plagioclase crystals in the crystal clusters is also dacitic to rhyolitic in composition (63$74 \mathrm{wt} \% \mathrm{SiO}_{2}$ ). Coarse grained plagioclase in the cumulate xenoliths has glass inclusions that fall into the same dacitic to rhyolitic compositional range $\left(65-70 \mathrm{wt} \% \mathrm{SiO}_{2}\right)$, however the upper end of this range is lower than in the previous crystal populations 
(Figure 86). It should be noted that glass was also analyzed in pyroxene phenocrysts, pyroxene in the cumulate gabbro xenoliths, and interstitial glass in the crystal clusters and gabbro xenoliths for comparison (details given in chapter 4). The interstitial glass in both the crystal clusters and cumulate xenoliths (64-75 wt\% $\mathrm{SiO}_{2}$ and 61-74 wt\% $\mathrm{SiO}_{2}$ respectively) and the glass in the pyroxene phenocrysts and coarse grains in cumulate xenoliths (65-74 wt $\% \mathrm{SiO}_{2}$ and $69-70 \mathrm{wt} \% \mathrm{SiO}_{2}$ respectively) have a similar $\mathrm{SiO}_{2}$ range to that found in the plagioclase crystals.

The two groups with the largest number of analyses are the glass in the plagioclase phenocrysts and the interstitial glass in the gabbroic xenoliths. Glass in plagioclase phenocrysts has a slightly different composition than the glass in the crystal clusters or gabbroic xenoliths, with some overlap, for all oxides except $\mathrm{TiO}_{2}$ and $\mathrm{P}_{2} \mathrm{O}_{5}$ (Figure 87). The glass in the plagioclase phenocrysts tends to have higher $\mathrm{MgO}, \mathrm{Fe}_{2} \mathrm{O}_{3}$, and $\mathrm{CaO}$ versus $\mathrm{SiO}_{2}$ than the glass in the gabbroic xenoliths or crystal clusters. For all three groups there is an overall negative correlation between $\mathrm{SiO}_{2}$ and $\mathrm{MgO}, \mathrm{Fe}_{2} \mathrm{O}_{3}$, and $\mathrm{CaO}$. Glass in the plagioclase phenocrysts is lower in $\mathrm{Al}_{2} \mathrm{O}_{3}$ than in the other two groups, and all three groups are positively correlated with $\mathrm{SiO}_{2}$. For $\mathrm{TiO}_{2}$ and $\mathrm{P}_{2} \mathrm{O}_{5}$ the glass in all three groups overlaps in composition and there is no correlation between these oxides and $\mathrm{SiO}_{2}$. The concentrations of these groups also overlaps for $\mathrm{K}_{2} \mathrm{O}$, however, glass in the plagioclase phenocrysts has a tightly defined trend which is positively correlated with $\mathrm{SiO}_{2}$ and the glass in the plagioclase in the crystal clusters and gabbroic xenoliths show significant scatter about the phenocryst trend. Compared with bulk rock analyses from Calbuco and Osorno lavas and Calbuco pyroclastic and debris flows and surge and fallout deposits, the bulk analysis of the glass in the three plagioclase populations shows trends 
of the oxide compositions that are not as narrowly defined as those of the eruptive products (Figure 88). Comparison of correlation trends with $\mathrm{SiO}_{2}$ show that the glass and eruptive products are negatively correlated with $\mathrm{SiO}_{2}$ for $\mathrm{MgO}, \mathrm{Fe}_{2} \mathrm{O}_{3}$, and $\mathrm{CaO}$ and positively correlated for $\mathrm{Na}_{2} \mathrm{O} . \quad \mathrm{Al}_{2} \mathrm{O}_{3}$ and $\mathrm{K}_{2} \mathrm{O}$ in the eruptive products have no correlation with $\mathrm{SiO}_{2}$, but the glass is positively correlated with $\mathrm{SiO}_{2}$ for each oxide. The glass pockets show no correlation with $\mathrm{SiO}_{2}$ for $\mathrm{TiO}_{2}$ and $\mathrm{P}_{2} \mathrm{O}_{5}$. The eruptive products show the same correlation for $\mathrm{P}_{2} \mathrm{O}_{5}$ as the glass pockets, however, the eruptive products are negatively correlated with $\mathrm{SiO}_{2}$ for $\mathrm{TiO}_{2}$.

\subsection{Summary}

Plagioclase found in Calbuco andesite and basaltic andesite can be grouped into five different crystal populations; 1) megacrysts, 2) phenocrysts, 3) plagioclase in the cumulate gabbroic xenoliths, 4) plagioclase in the crystal clusters, and 5) plagioclase in the hornblende breakdown reaction products. Megacrysts have large, unzoned, high An cores and thin, zoned outer rims and phenocrysts have lower An cores and are predominantly zoned. Plagioclase in the gabbroic xenoliths is predominantly unzoned with only rare zoned crystals; similarly, plagioclase in the crystal clusters is predominantly unzoned with few zoned crystals. Plagioclase formed by hornblende breakdown is discussed in chapter 5. Rims found on megacrysts are normally zoned while phenocryst zoning is primarily normal zoning overprinted with oscillatory zoning with rare reverse zoning. Some phenocrysts also have patchy zoning. Minor and trace element incorporation with major element zoning in the phenocrysts and megacrysts was also looked at for $\mathrm{Fe}, \mathrm{Mg}, \mathrm{Ti}$, and $\mathrm{Sr}$. Based on partitioning experiments, all four of these elements would be expected to have a negative correlation with An mol\%, which is the 
case for $\mathrm{Mg}$ in the plagioclase in the andesite and basaltic andesite, and $\mathrm{Ti}$ and $\mathrm{Sr}$ in the plagioclase in the basaltic andesite. This trend is not seen for Fe in the plagioclase in both the andesite and basaltic andesite and for $\mathrm{Ti}$ and $\mathrm{Sr}$ in the andesite.

Plagioclase resorption textures and surfaces, and the crystal growth between resorption events, have been examined on phenocrysts in the andesite and basaltic andesite. Resorption can be the result of increased magmatic temperature or increased dissolved $\mathrm{H}_{2} \mathrm{O}$ in the magma. Resorption textures found are patchy zoning and sieve textured plagioclase, and two types of resorption surfaces can be identified; major resorption surfaces, which cut across more than one plagioclase zone, and minor resorption surfaces, which cut across only one other zone. Between these resorption surfaces, plagioclase growth zones contain three different types of oscillatory zoning. Type 1 oscillatory zoning has An mol\% fluctuation up to 2 mol\%, type 2 zoning has An mol\% fluctuation of $2-5 \mathrm{An} \mathrm{mol} \%$, and type 3 zoning has fluctuations of up to $10 \mathrm{An}$ mol\% or higher. Both type 1 and type 2 oscillatory zoning occur without visible resorption surfaces, while type 3 oscillatory zoning occurs with both visible major and minor resorption surfaces.

Glass found in plagioclase phenocrysts, plagioclase in crystal clusters, and plagioclase in gabbroic xenoliths has overlapping compositional ranges of dacitic to rhyolitic, which is also similar to the compositional range of glass found interstitially in gabbroic xenoliths and crystal clusters, as well as pyroxene crystals. For most oxides, glass found in the phenocrysts has a slightly different composition than glass in the gabbroic xenoliths or crystal clusters. Compared with bulk analysis of Calbuco eruptive products (lavas, pyroclastic flows, debris flows, surge deposits, and fallout deposits), the 
glass found in these three plagioclase populations show trends of oxide compositions which are not as narrowly defined as those of the eruptive products. 

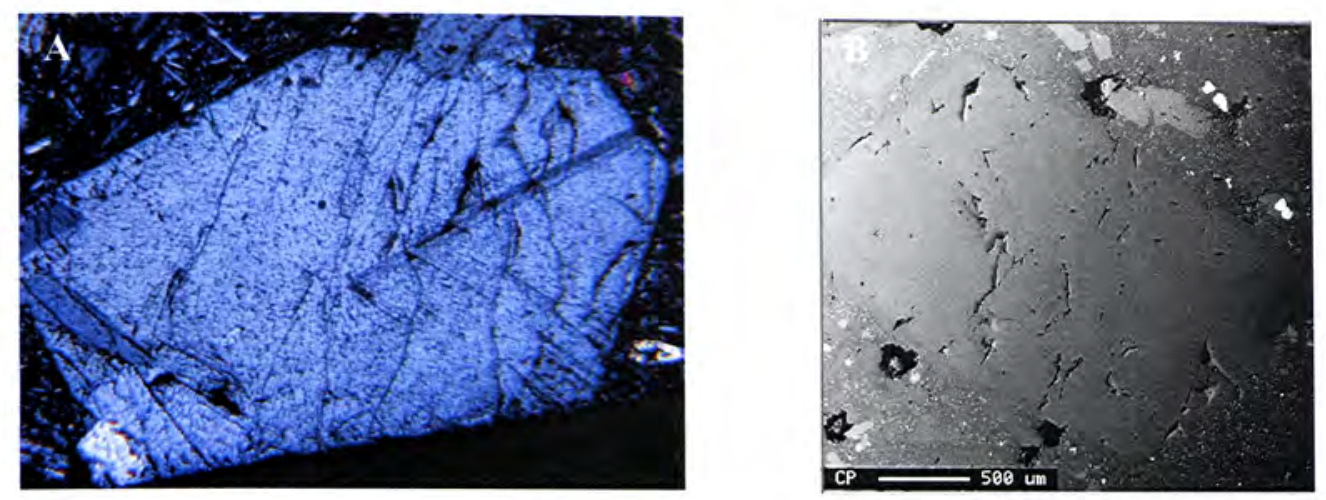

Figure 62: Photomicrographs of plagioclase megacrysts.

A: Photomicrograph of plagioclase megacryst in cross polarized light. Field of view is $2.8 \mathrm{~mm}$. B: Backscattered electron image of plagioclase megacryst.

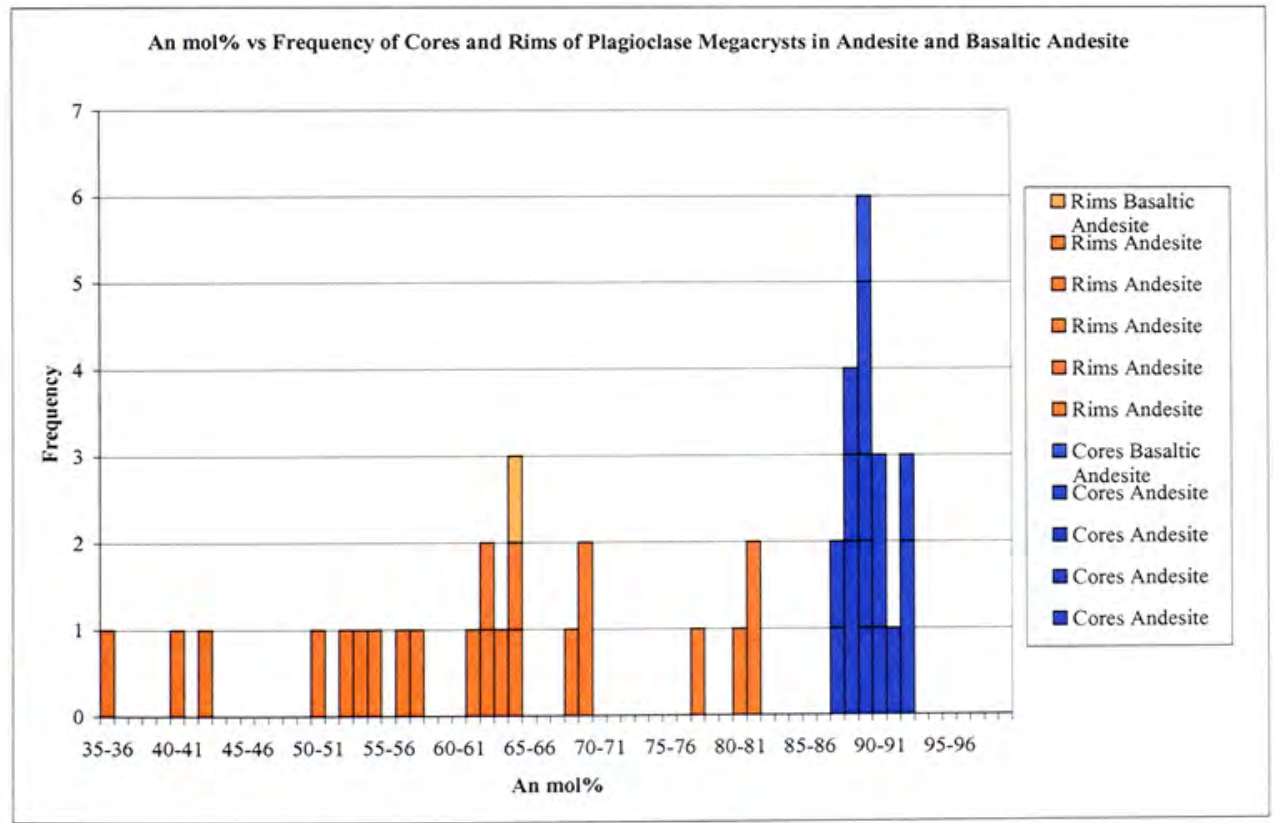

Figure 63: Histogram of plagioclase megacrysts.

Histogram of An mol\% versus frequency of core and rim analyses from plagioclase megacrysts in andesite and basaltic andesite. 

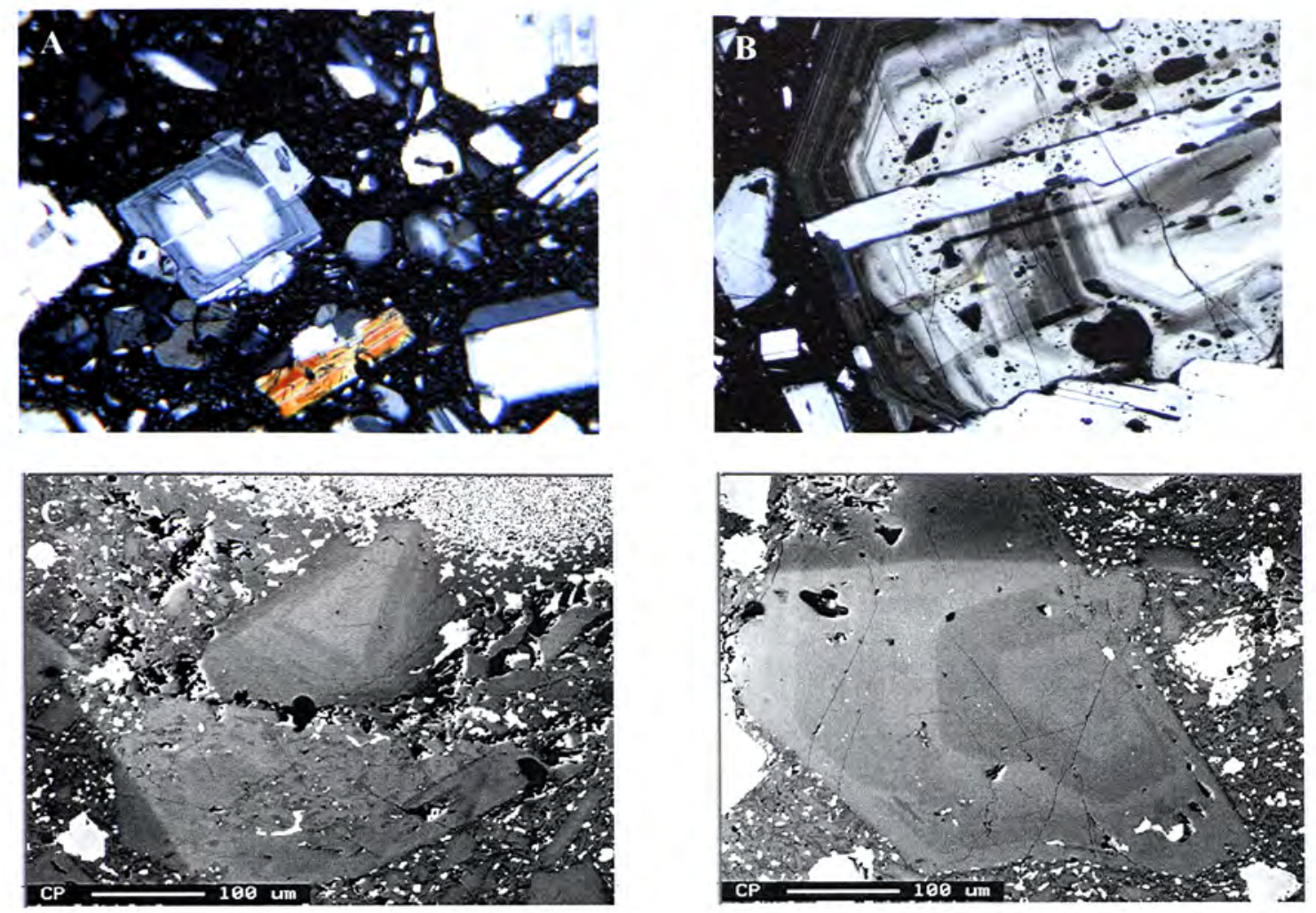

Figure 64: Images of plagioclase phenocrysts.

A, B: Photomicrographs of zoned plagioclase phenocrysts in cross-polarized light. Field of view is $2.8 \mathrm{~mm}$. C, D: Backscattered electron images of zoned plagioclase phenocrysts. 


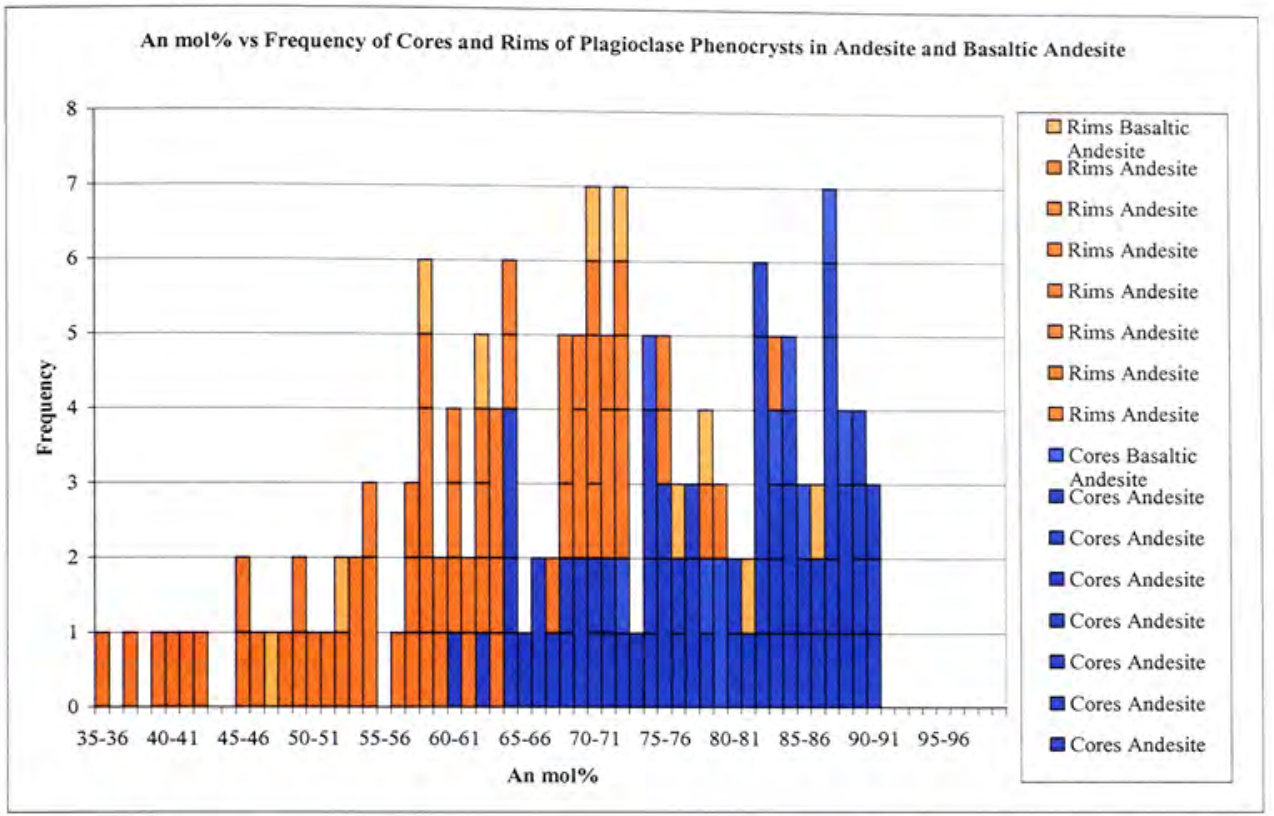

Figure 65: Histogram of plagioclase phenocrysts.

Histogram of An mol\% versus frequency of core and rim analysis of plagioclase phenocrysts in both andesite and basaltic andesite. 
Table 8: Point count analysis of andesite.

Part 1: Point counting analysis showing the modal abundance of the mineral phases in andesitic samples. Part 2: Point count analysis showing modal abundance of melt inclusions/glass.

\begin{tabular}{|c|c|c|}
\hline Part 1 & \multicolumn{2}{|c|}{ Modes } \\
\hline Sample & $12-19-8 a$ & 32825 \\
\hline Groundmass & 44.4 & 48.1 \\
\hline Opaque Minerals & 2.7 & 3.4 \\
\hline Mafic Silicates & 15.1 & 37.2 \\
\hline Plagioclase & 37.9 & 69.1 \\
\hline $\begin{array}{c}\text { Phenocrysts } \\
(>.13 \text { mm) }\end{array}$ & 72.5 & 31.0 \\
\hline $\begin{array}{c}\text { Microphenocrysts } \\
(<.13 \mathrm{~mm})\end{array}$ & 27.9 & \\
\hline
\end{tabular}

\begin{tabular}{|c|c|c|c|}
\hline Part 2 & \multicolumn{3}{|c|}{ Crystal and Melt Inclusion Modes } \\
\hline Sample & $12-19-8 a$ & 32825 & \\
\hline & Phenocrysts & Microphenocrysts & Phenocrysts \\
\hline Melt Inclusions & & 12.8 & 16.1 \\
\hline Clustered in Center & 37.1 & 4.3 & 17.8 \\
\hline Single Zone & 21.0 & 51.1 & 55.2 \\
\hline Spread Out & 63.7 & 4.3 & 21.3 \\
\hline Very Large & 23.4 & 29.8 & 21.8 \\
\hline None & 0.8 & 0 & 0 \\
\hline Radiating & 4.0 & & \\
\hline
\end{tabular}




\begin{tabular}{|c|c|c|c|}
\hline Crystals & \multicolumn{3}{|l|}{} \\
\hline Anhedral & 62.9 & 57.5 & 70.7 \\
\hline Euhedral & 37.1 & 42.6 & 29.3 \\
\hline Resorbed Center & 21.8 & 2.1 & 13.2 \\
\hline Zoned & 88.3 & 68.1 & 86.8 \\
\hline
\end{tabular}



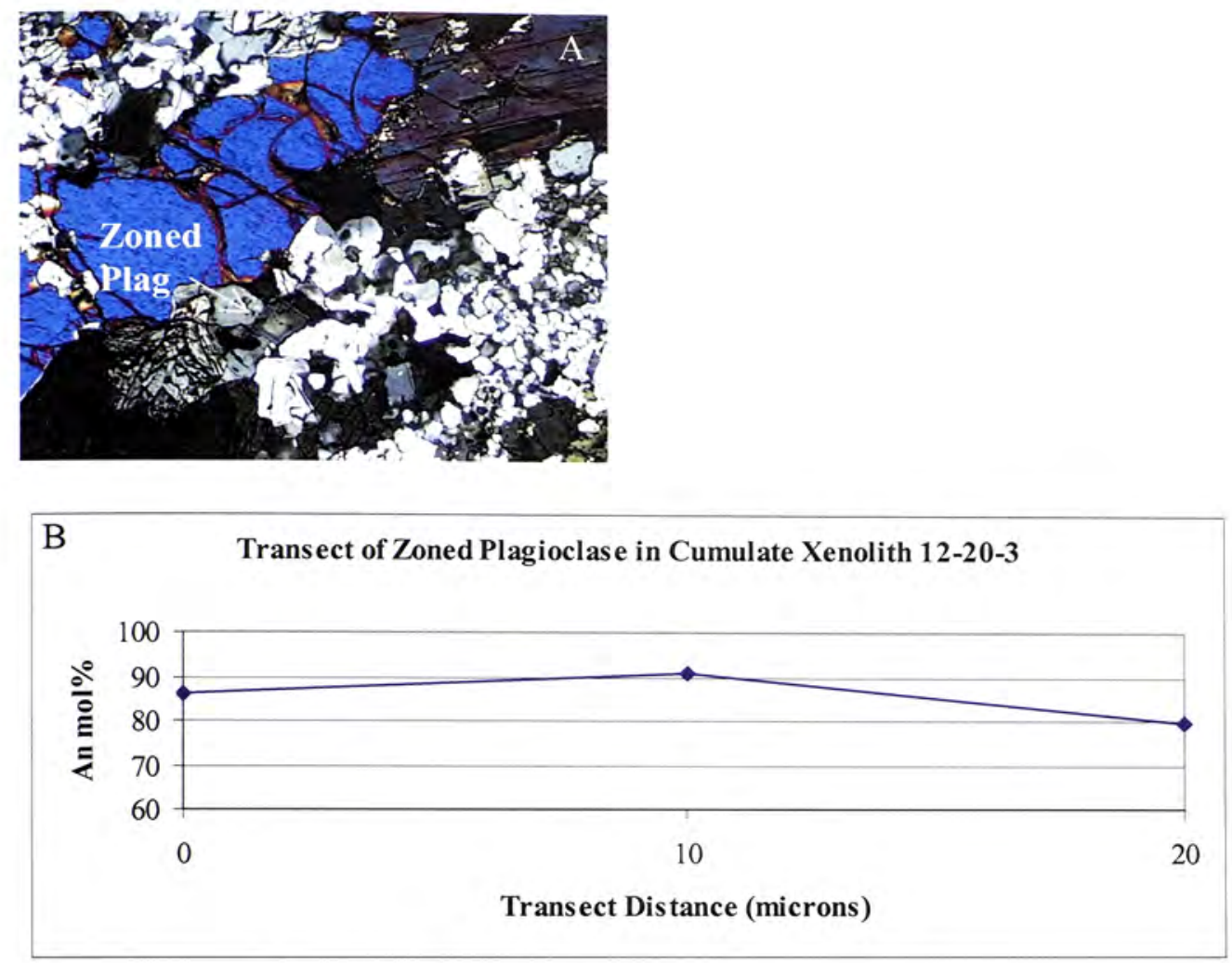

Figure 66: Zoned plagioclase in gabbroic xenolith.

A: Photomicrograph in cross polarized light of zoned plagioclase grain in cumulate gabbroic xenolith. Field of view is $2.8 \mathrm{~mm}$. B: core to rim transect of zoned plagioclase grain.
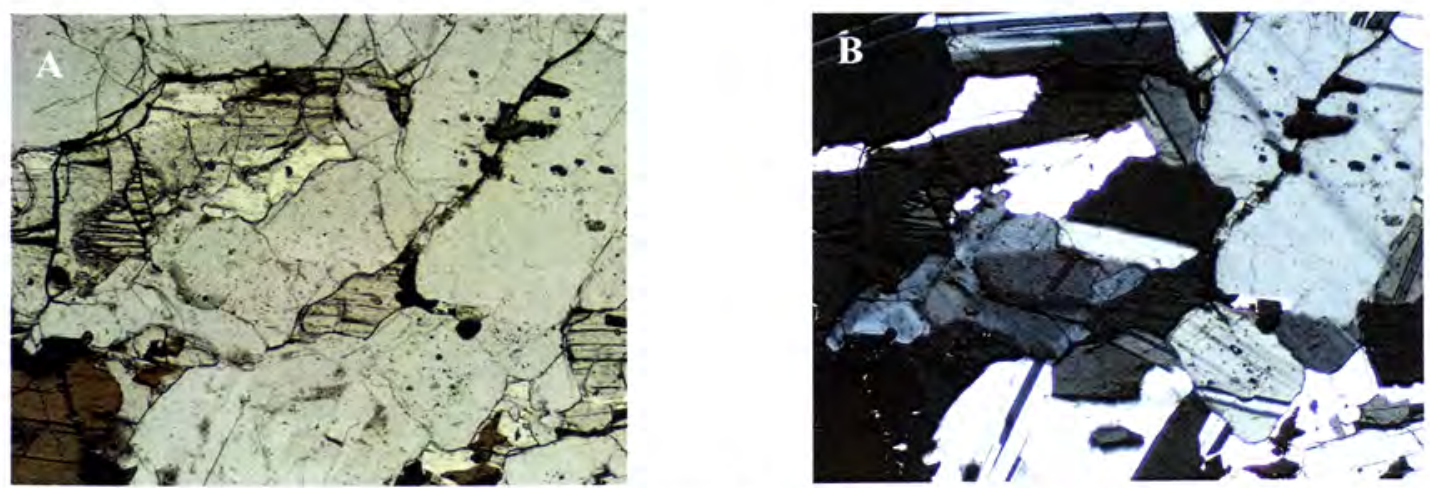

Figure 67: Photomicrographs of plagioclase in gabbroic xenolith 12-19-18.

Photomicrograph in plane polarized (A) and cross polarized (B) of plagioclase in cumulate xenolith sample 12-19-18 showing little or no breakdown. Field of view is 2.8 $\mathrm{mm}$. 

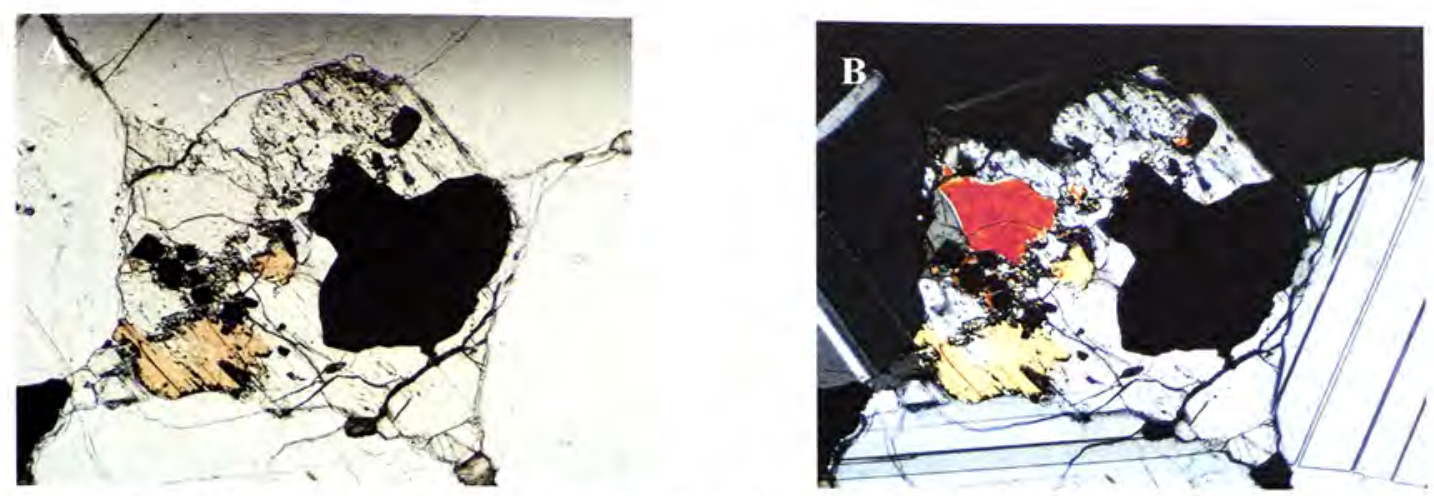

Figure 68: Photomicrographs of plagioclase in gabbroic xenolith 12-20-8.

Photomicrographs in plane polarized (A) and cross polarized (B) light of plagioclase in cumulate xenolith sample 12-20-8 showing little or no breakdown. Field of view is 2.8 mm.
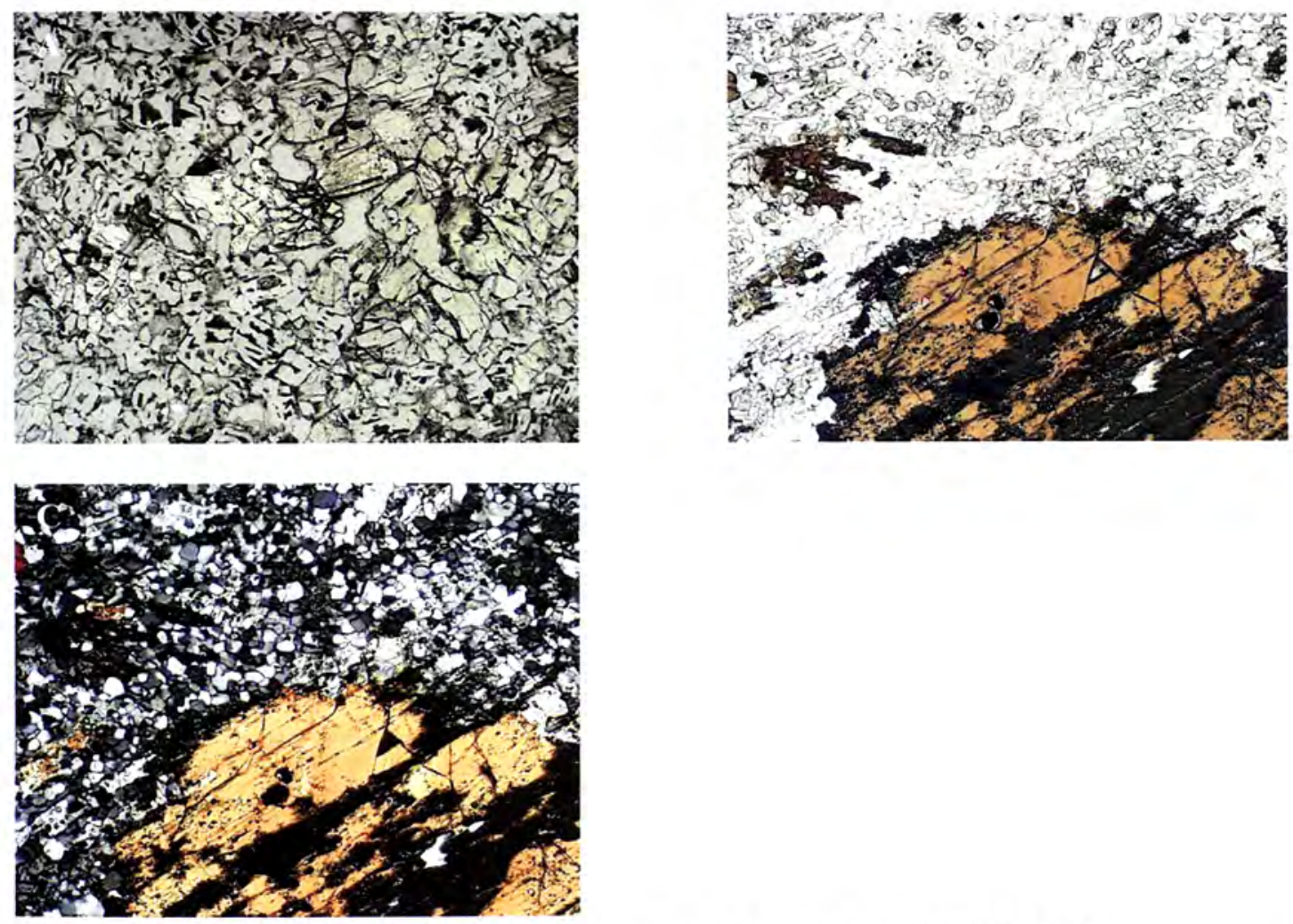

Figure 69: Photomicrographs of plagioclase in gabbroic xenolith 12-20-3.

Photomicrographs in plane polarized (A, B) and cross polarized (C) light of plagioclase in cumulate xenolith sample $12-20-3$. Field of view is $2.8 \mathrm{~mm}$. A shows spongy textured plagioclase with glass. $\mathrm{B}$ and $\mathrm{C}$ show microcrystalline plagioclase. 

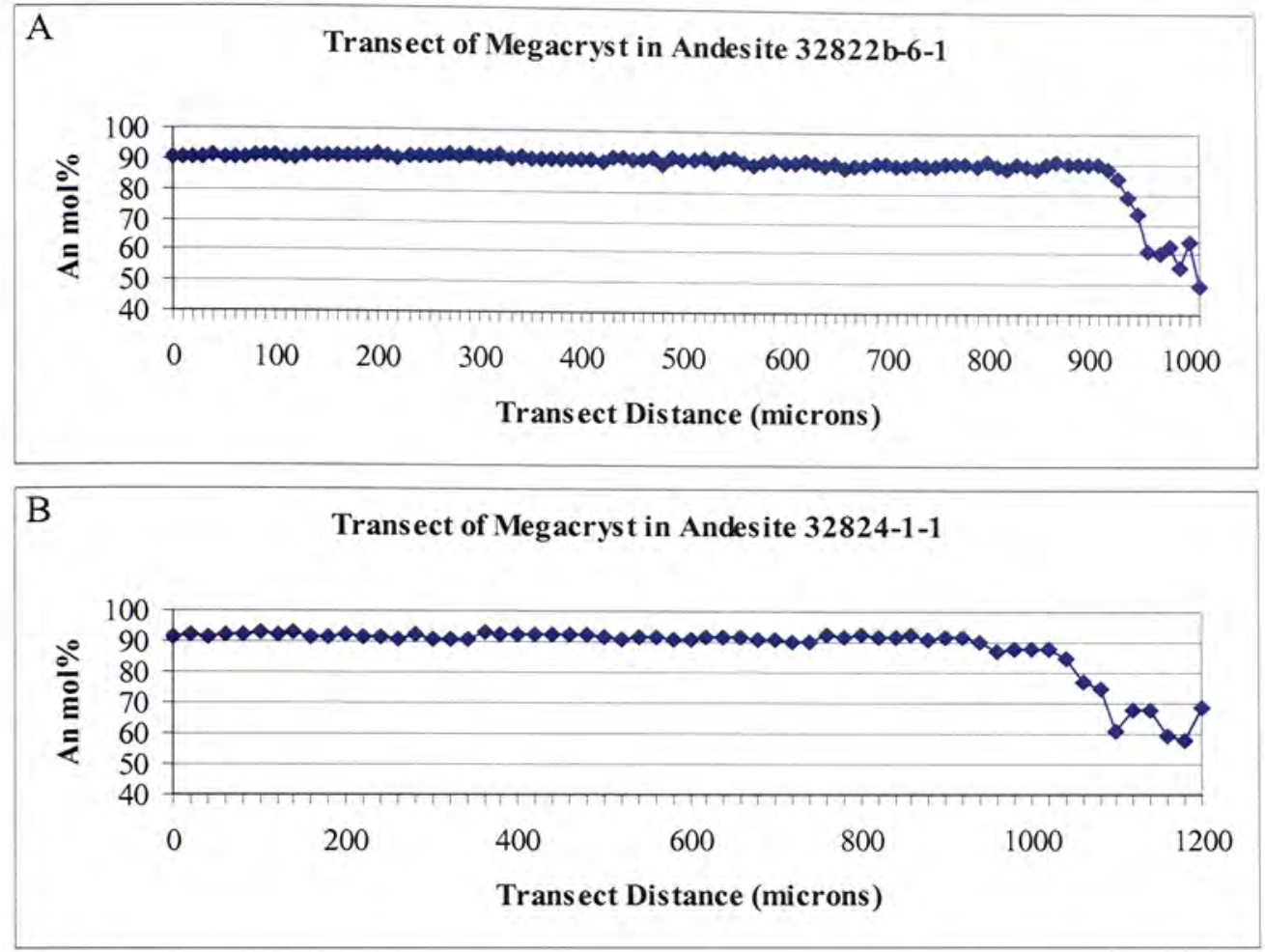

Figure 70: Transects of plagioclase megacrysts in andesite.

Representative plagioclase transects, taken core to rim, of megacrysts in andesite samples. The complete data set is in appendix D.

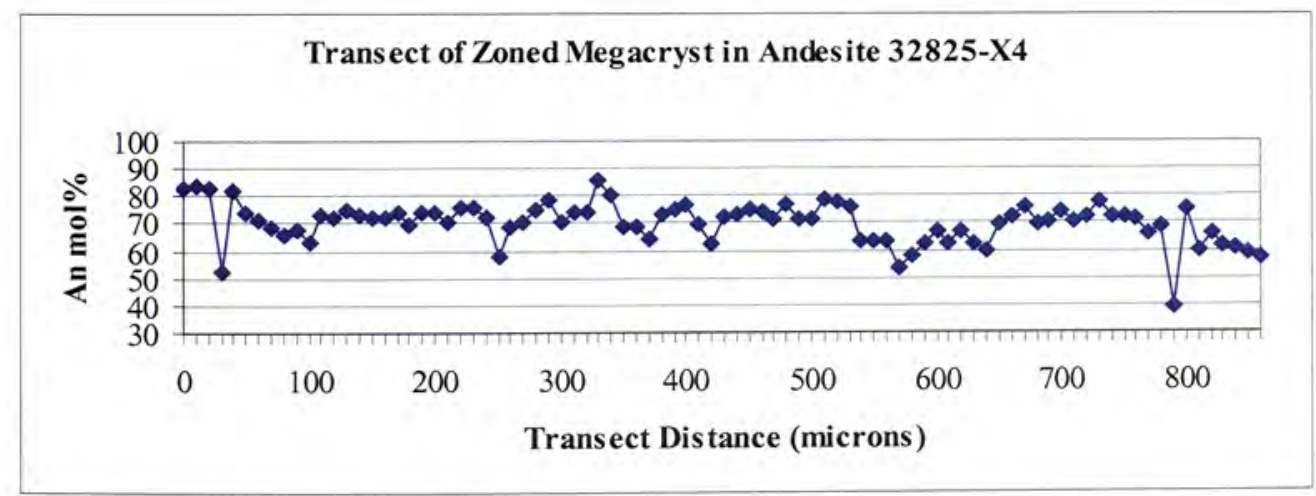

Figure 71: Transect of zoned megacryst in andesite.

Transect of zoned plagioclase megacryst in andesite from core to rim. 


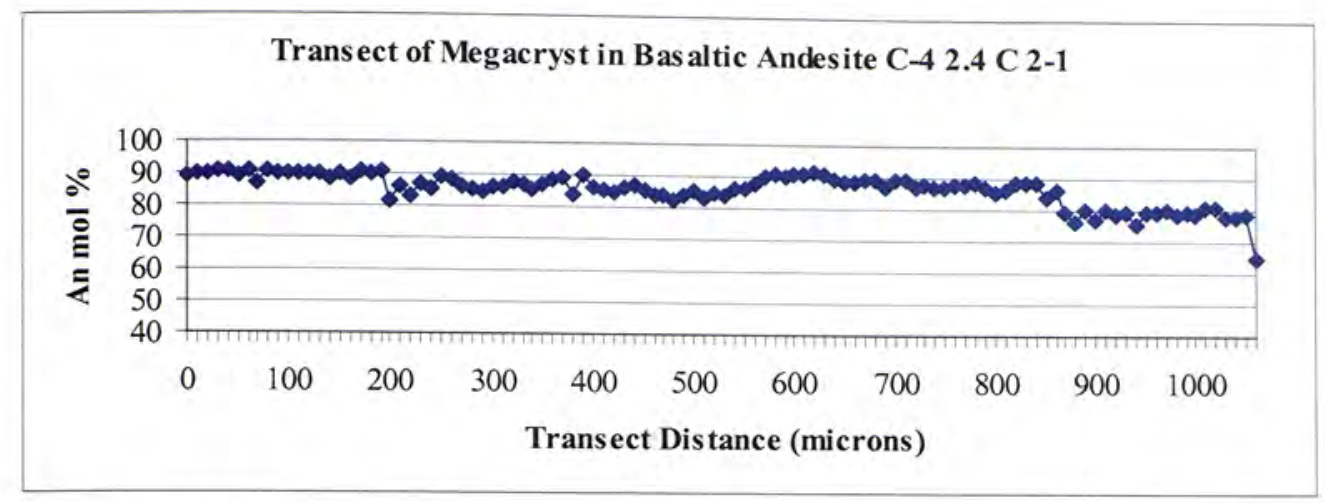

Figure 72: Transect of megacryst in basaltic andesite.

Transect of plagioclase megacryst in basaltic andesite from core to rim.
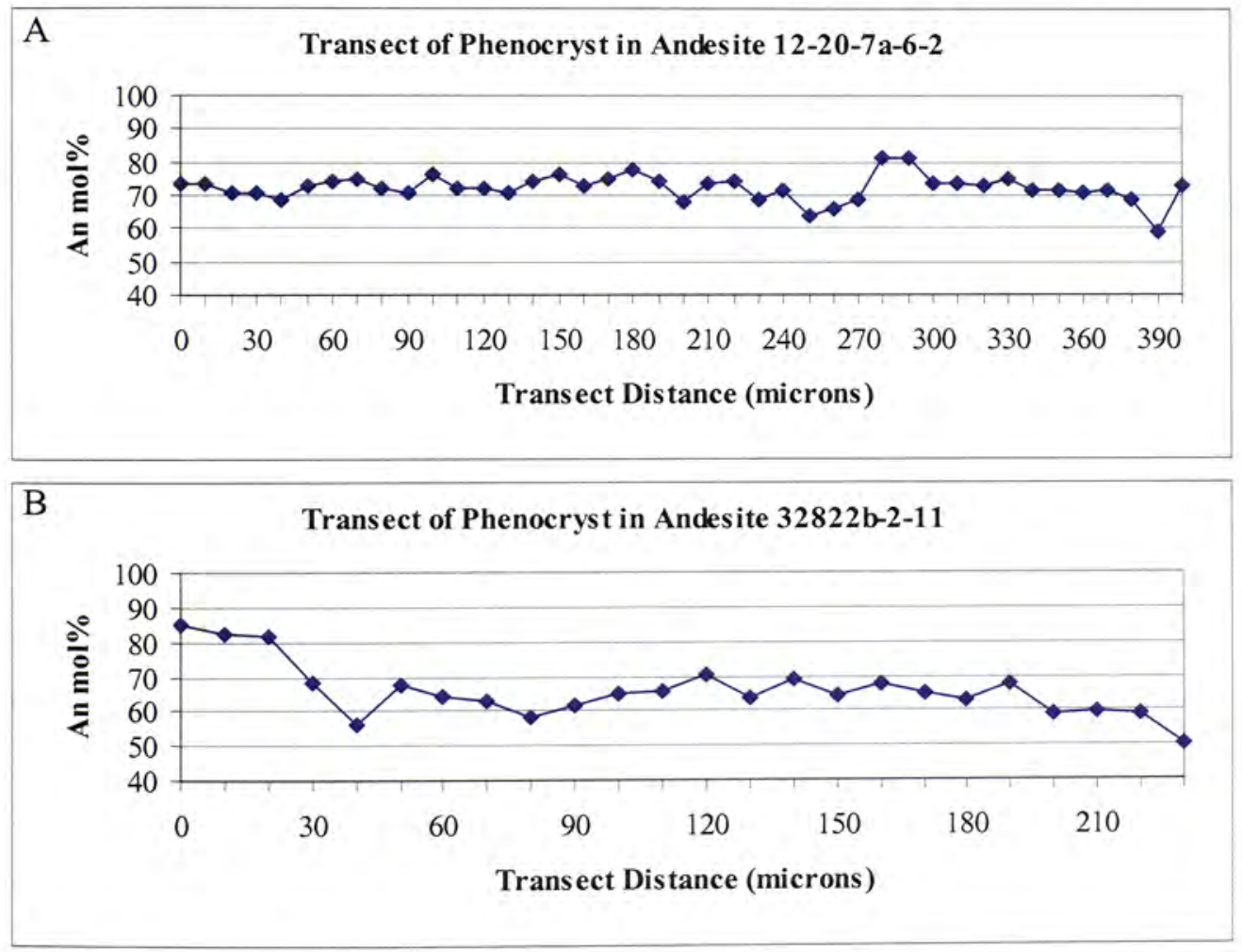

Figure 73: Transects of plagioclase phenocrysts in andesite.

Representative transects of normally zoned plagioclase phenocrysts in andesite, taken from core to rim. Complete data set in appendix D. 

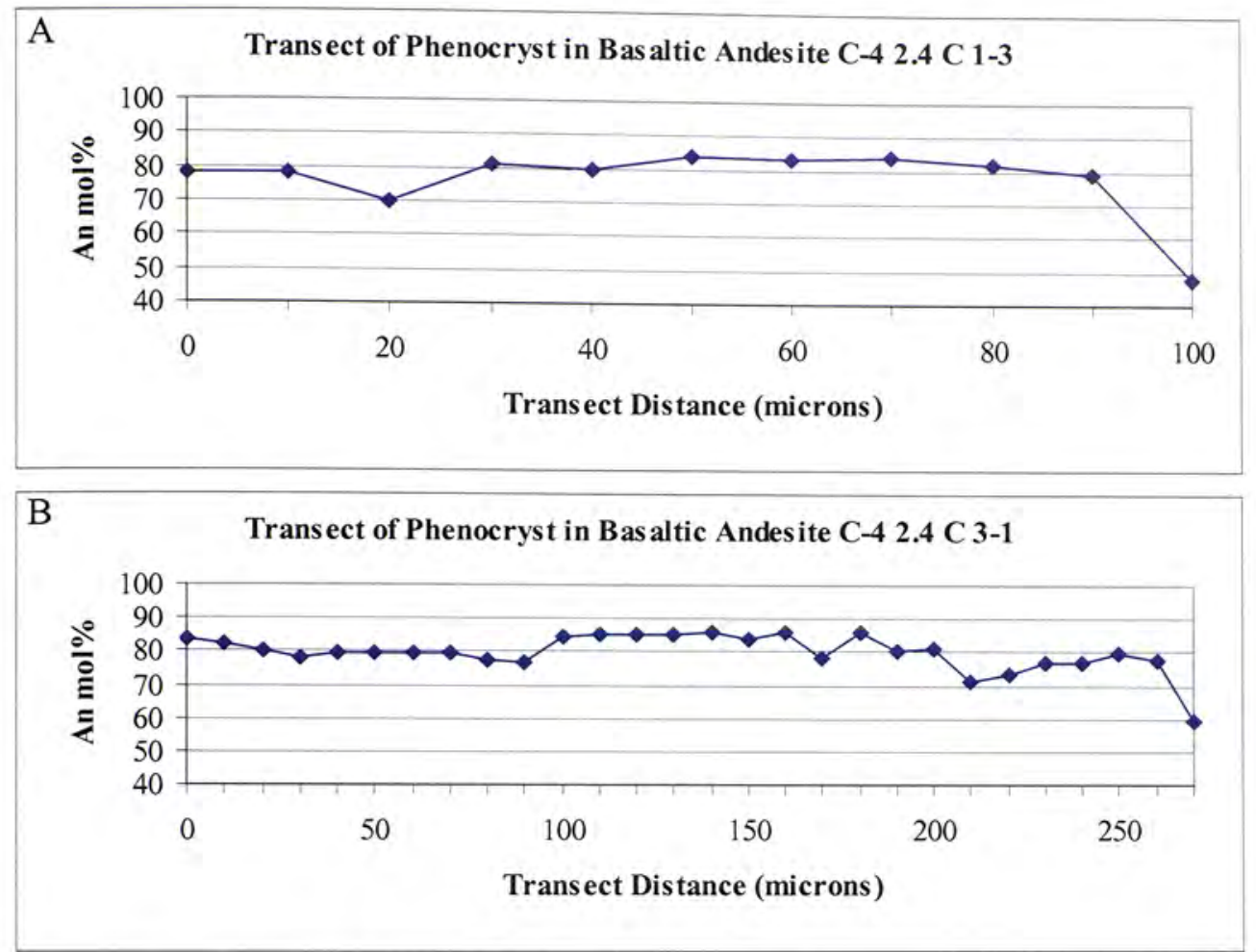

Figure 74: Transects of plagioclase phenocrysts in basaltic andesite.

Representative transects of normally zoned plagioclase phenocrysts in basaltic andesite, taken from core to rim. Complete data set in appendix D.

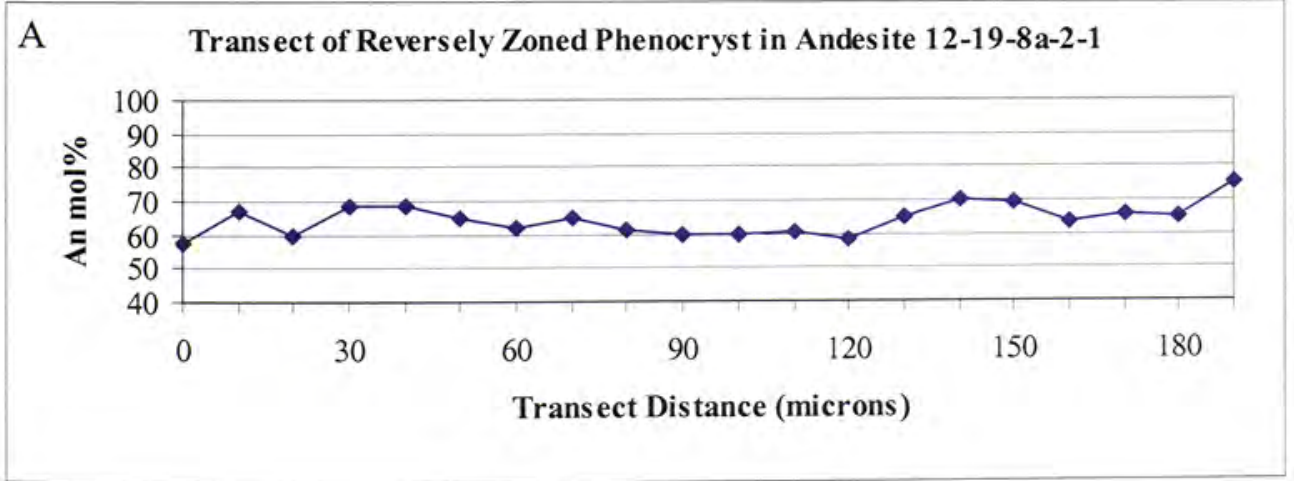



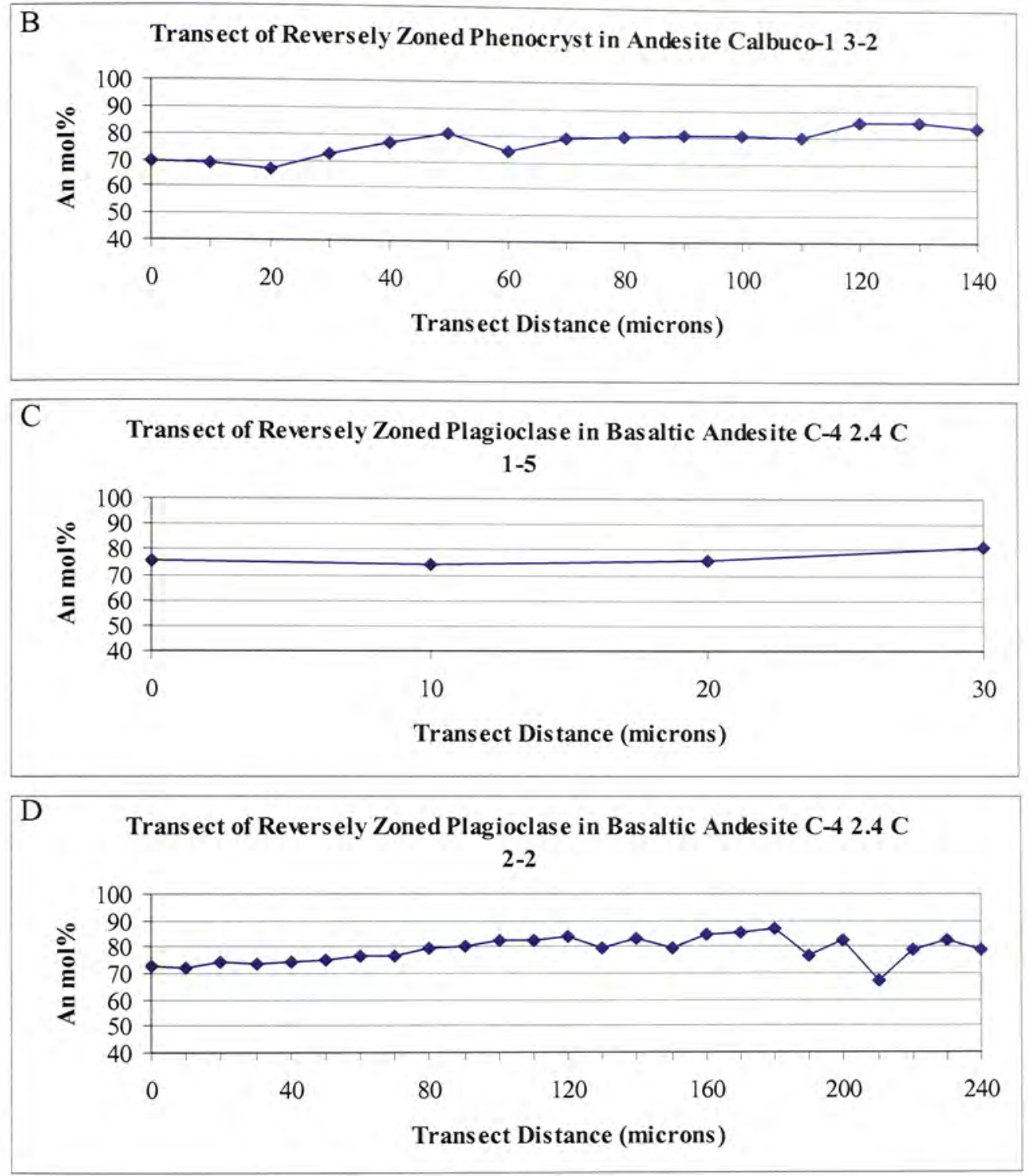

Figure 75: Reversely zoned transects of plagioclase phenocrysts in andesite and basaltic andesite.

Representative transects of reversely zoned plagioclase phenocrysts in andesite (top two) and basaltic andesite (bottom 2), taken from core to rim. Complete data set is in appendix D. 

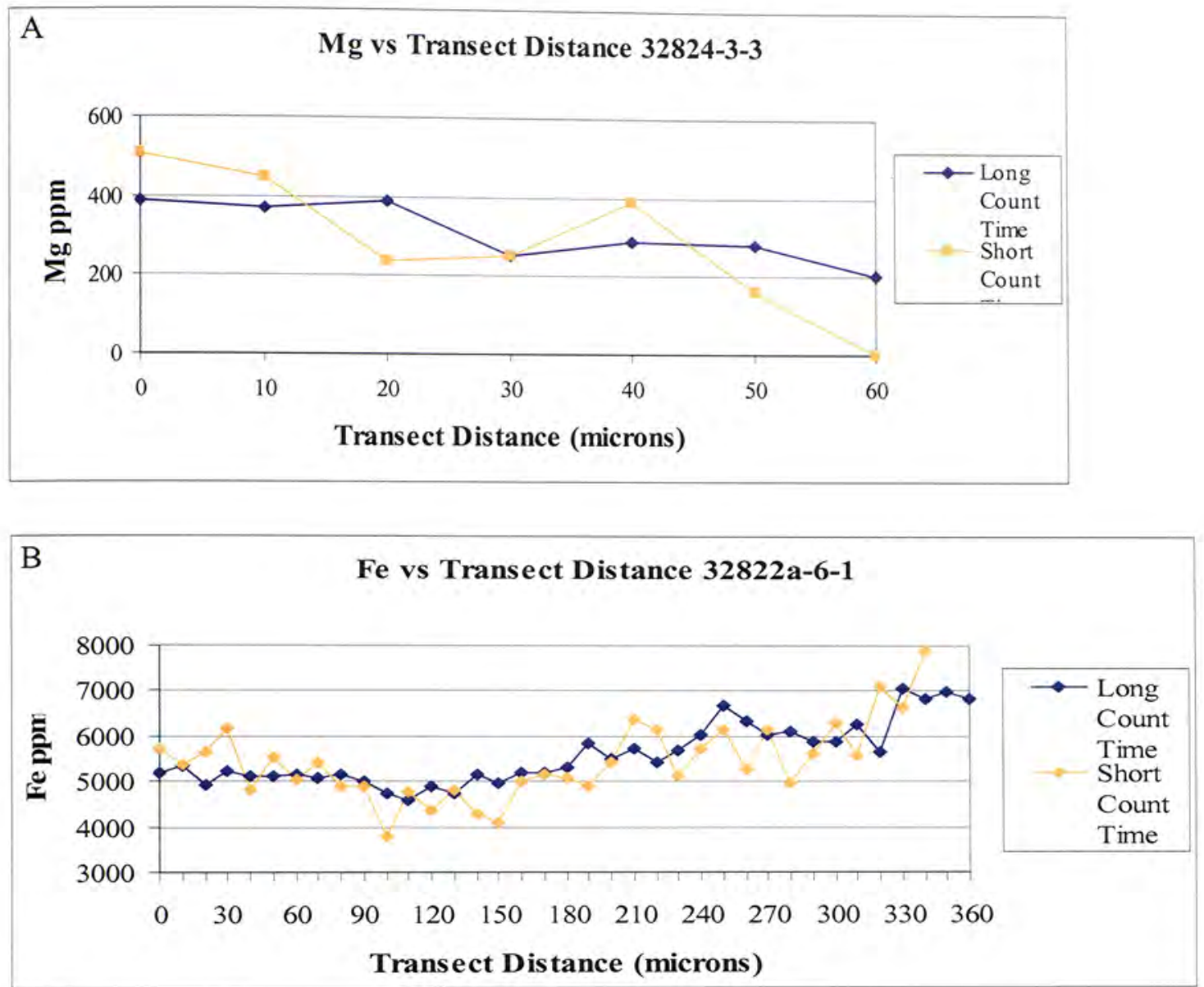

Figure 76: Trace element transects comparing electron microprobe count times.

Transects of plagioclase comparing $\mathrm{Fe}$ and $\mathrm{Mg}$ concentrations detected with long and short count times. Long count times were 240 seconds with 80 seconds background counting and short count times were 30 seconds with 10 seconds background counting. 

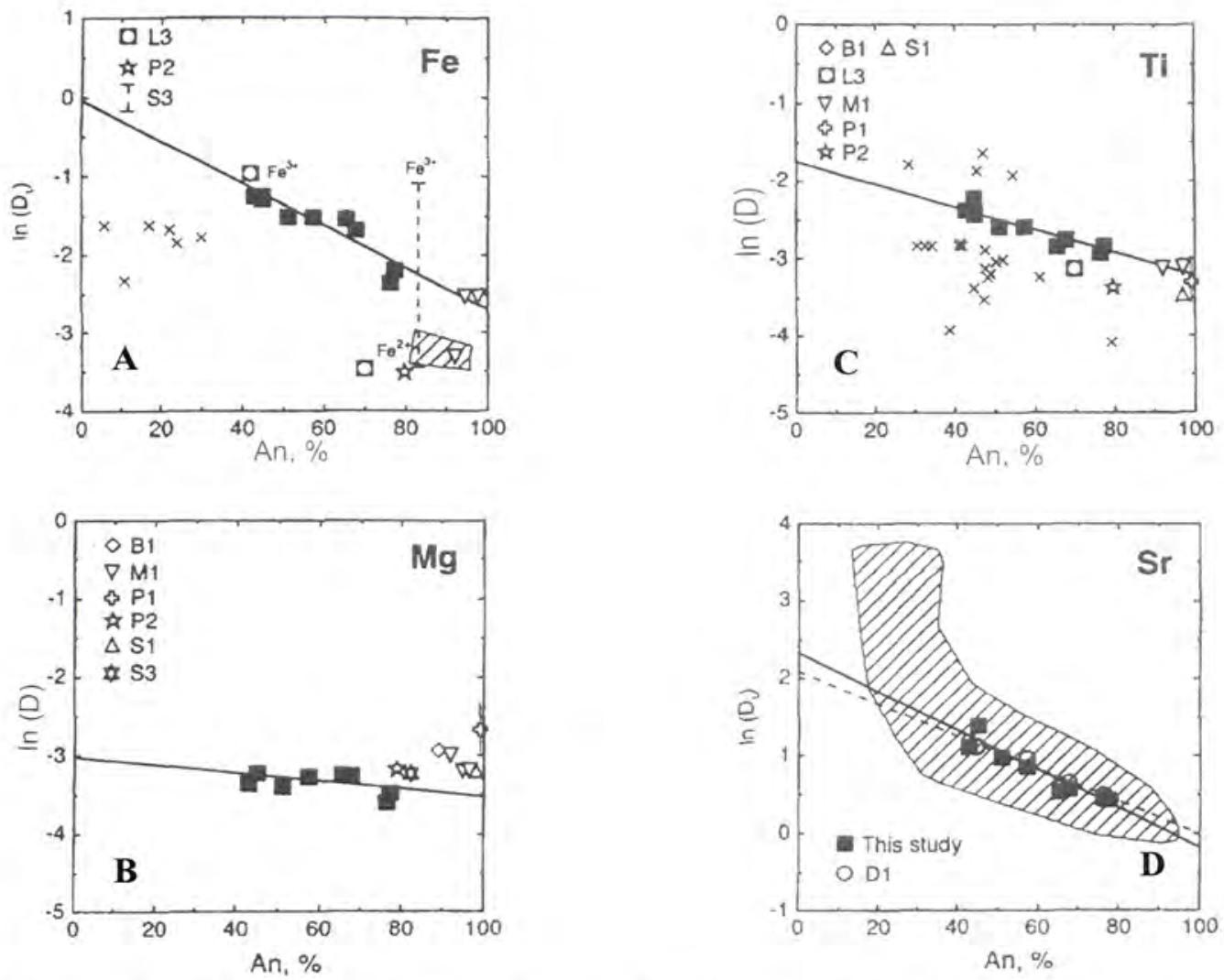

Figure 77: An mol\% versus. trace element partition coefficients.

An mol\% versus partition coefficients for partitioning of $\mathrm{Fe}(\mathrm{A}), \mathrm{Mg}(\mathrm{B}), \mathrm{Ti}(\mathrm{C})$, and $\mathrm{Sr}$ (D) into plagioclase showing a negative correlations. Negative correlation with $\mathrm{Mg}$ is slight. Figures from Bindeman et al. (1998). 


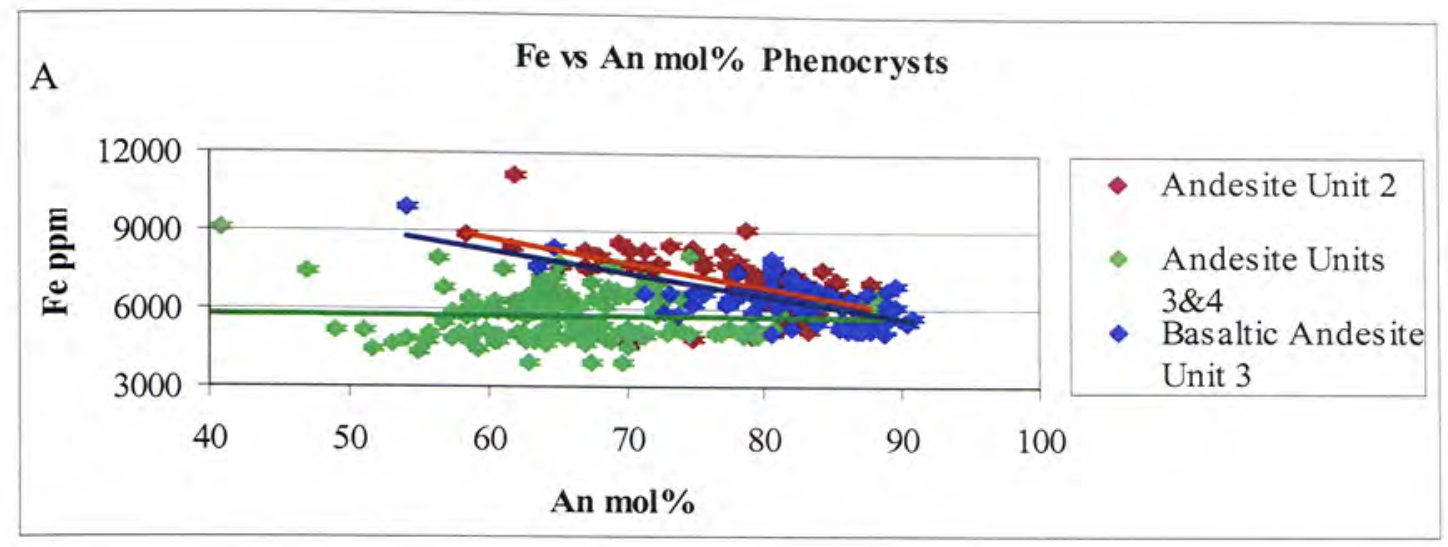

B

Fe us An mol\% Megacrysts
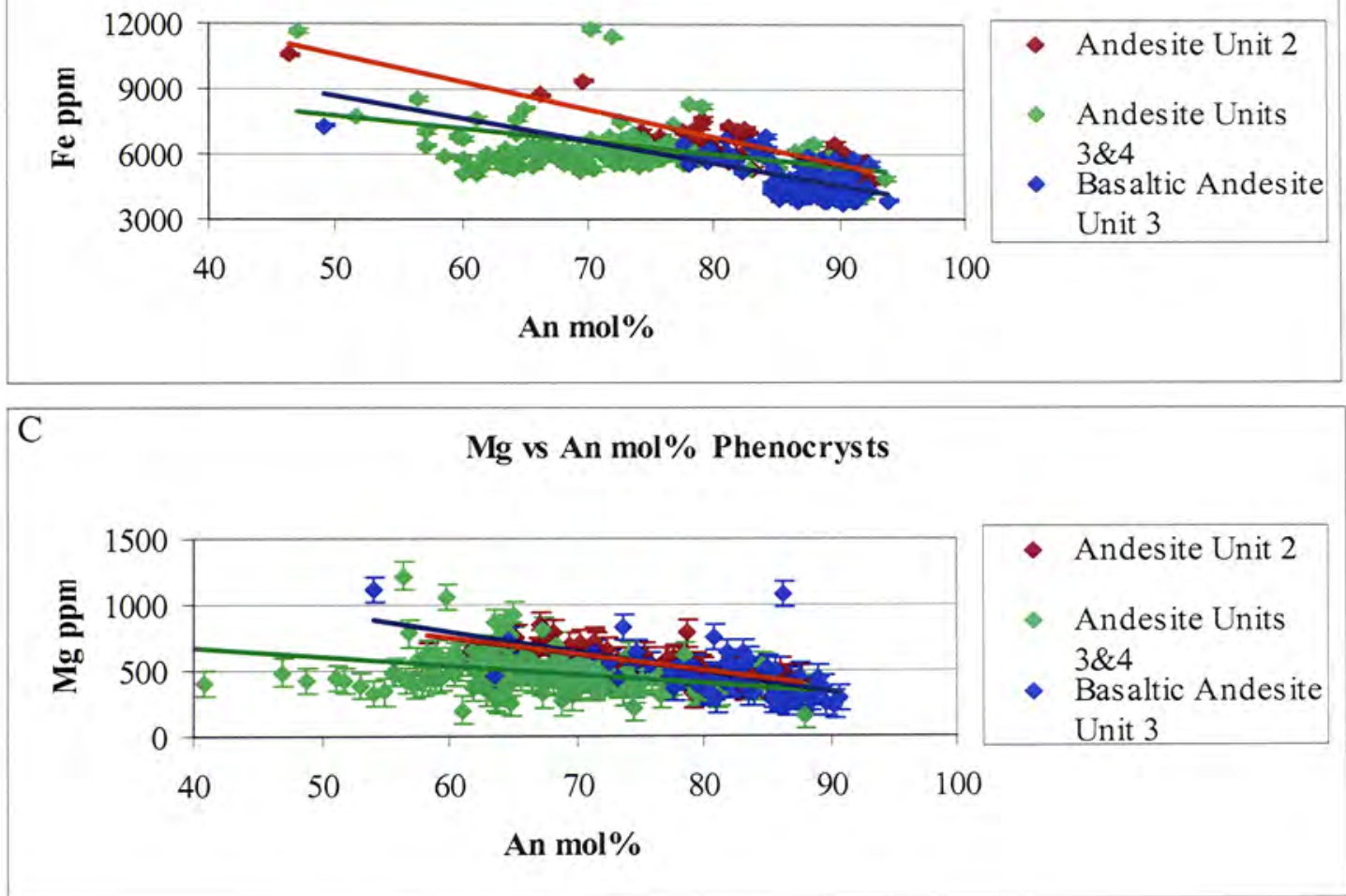

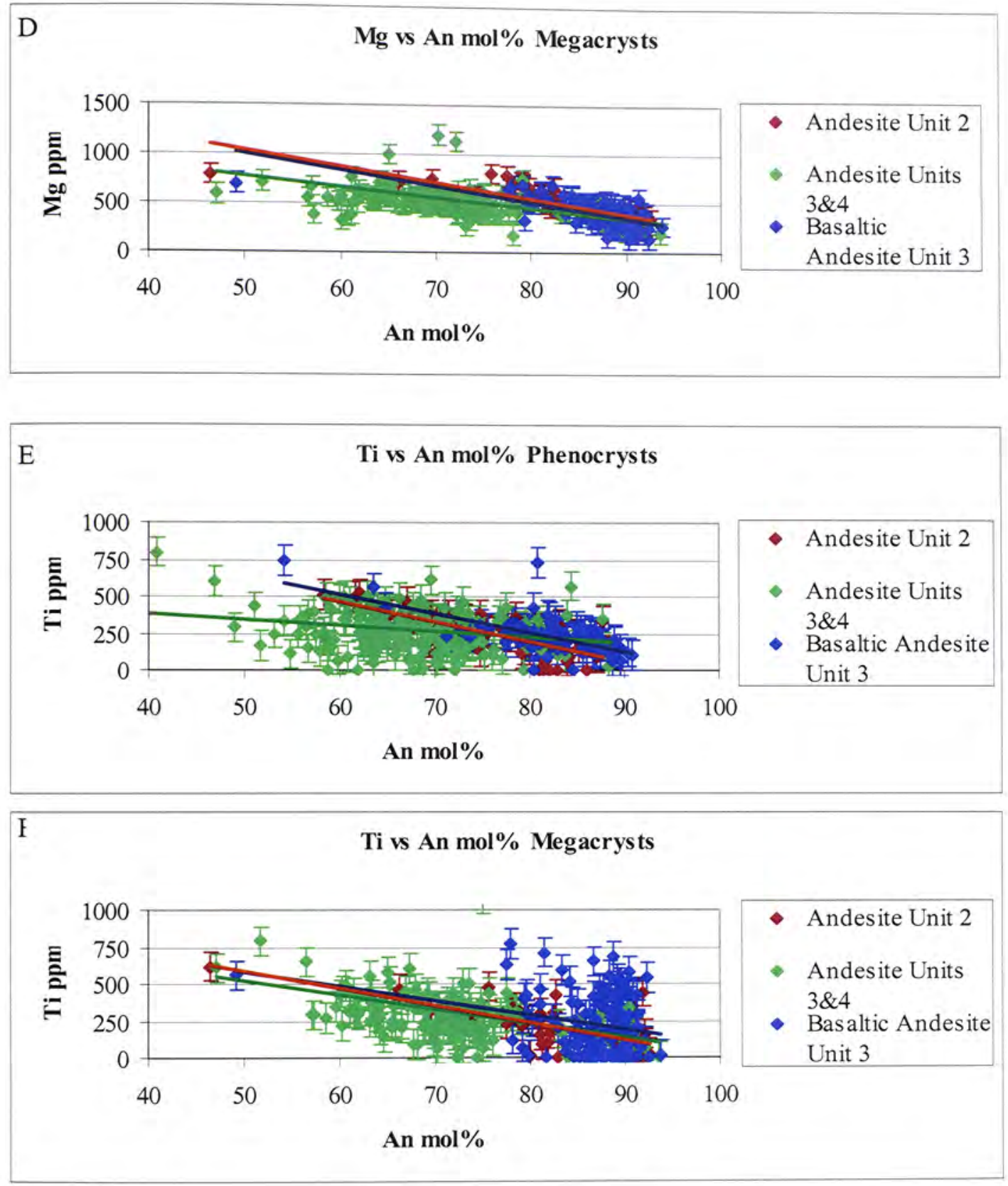

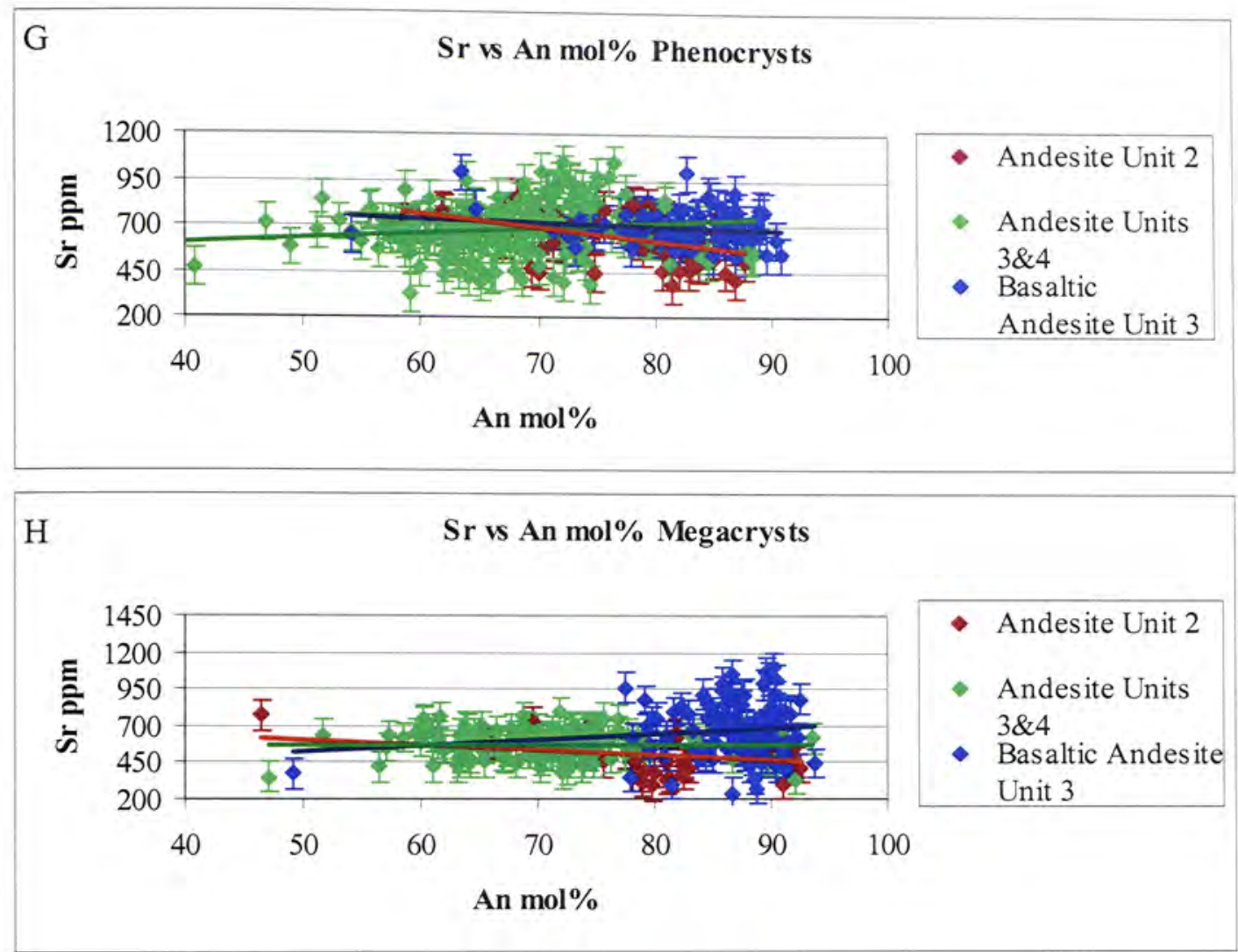

Figure 78: An mol\% versus. trace element concentrations in plagioclase phenocrysts. Plots of An mol\% versus trace element concentration (A, B: Fe; C, D: Mg; E, F: Ti; G, H: $\mathrm{Sr}$ ) in plagioclase phenocrysts and megacrysts from both andesite and basaltic andesite samples. $\mathrm{Fe}, \mathrm{Mg}$, and $\mathrm{Ti}$ show a negative correlation with $\mathrm{An} \mathrm{mol} \%$, although the phenocrysts in unit 3 and 4 andesite show only a slight negative correlation for $\mathrm{Fe}$. $\mathrm{Sr}$ correlation with An $\mathrm{mol} \%$ is more variable. 

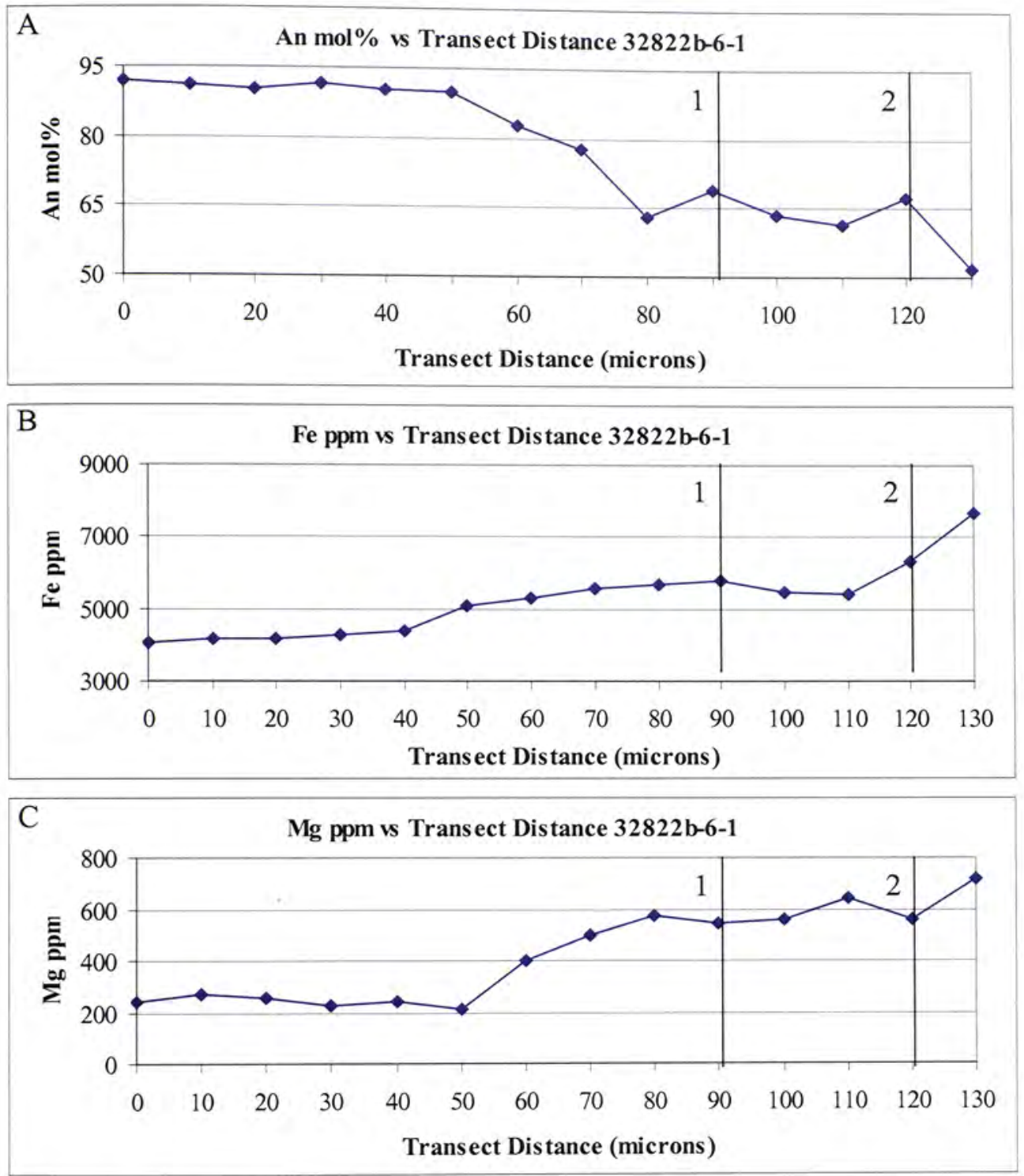

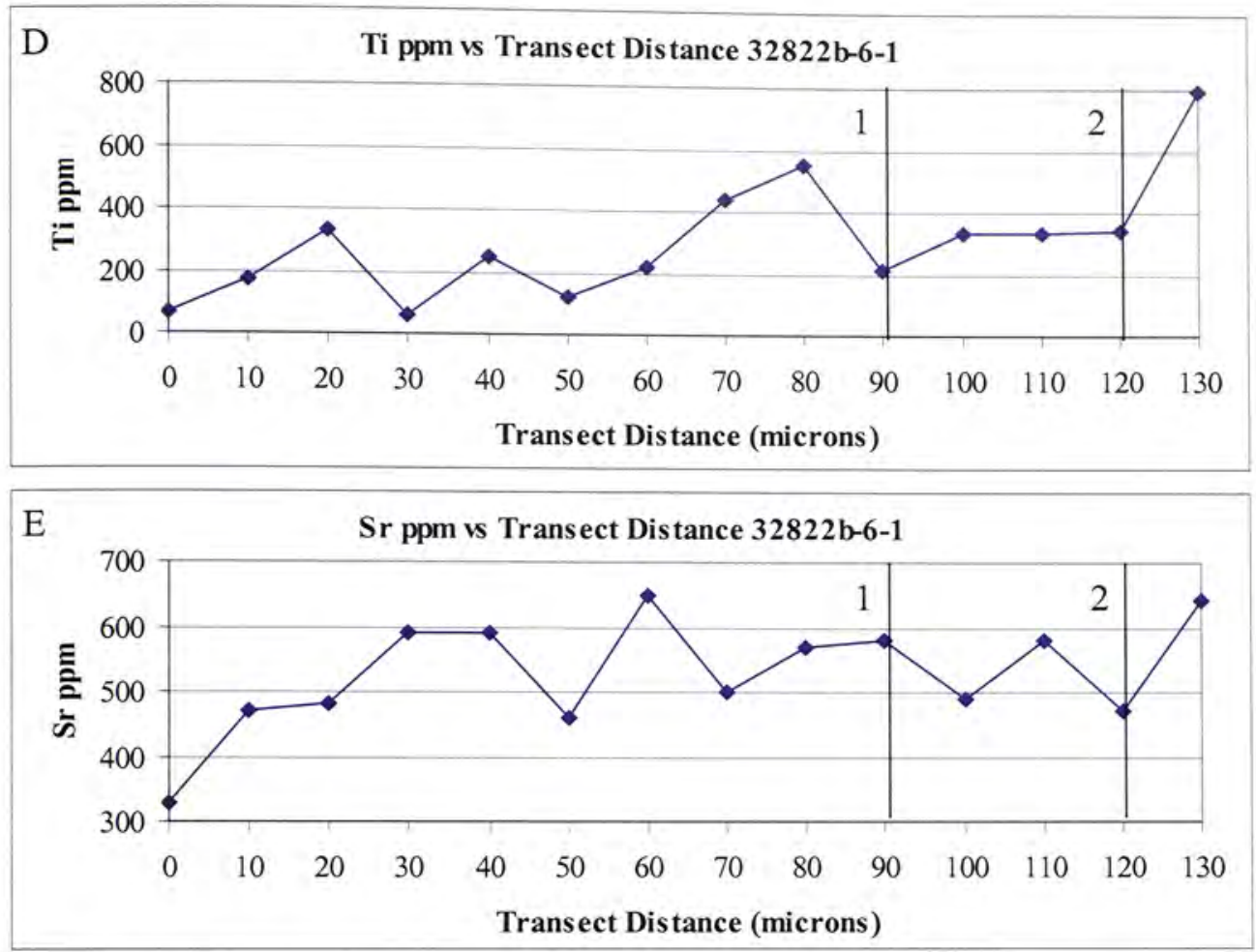

Figure 79: Trace element transect comparison with An mol\% in andesite.

Representative trace element transects of $\mathrm{Fe}, \mathrm{Mg}$, $\mathrm{Ti}$, and $\mathrm{Sr}$ versus $\mathrm{An} \mathrm{mol \%}$ in plagioclase in andesitic samples. Two An mol\% spikes, labeled 1 and 2, of greater than 5 mol\% have been correlated with respective points on the trace element transects. At both points 1 and $2 \mathrm{Fe}$ is increasing with increasing $\mathrm{An} \mathrm{mol} \%$. Mg is decreasing in correlation with both points. Ti is decreasing with $\mathrm{An} \mathrm{mol} \%$ at point 1 but increasing at point 2 . Sr is increasing at point 1 and decreasing at point 2 . The complete data set showing trace element comparisons with An mol\% spikes in andesitic samples is in appendix D. 

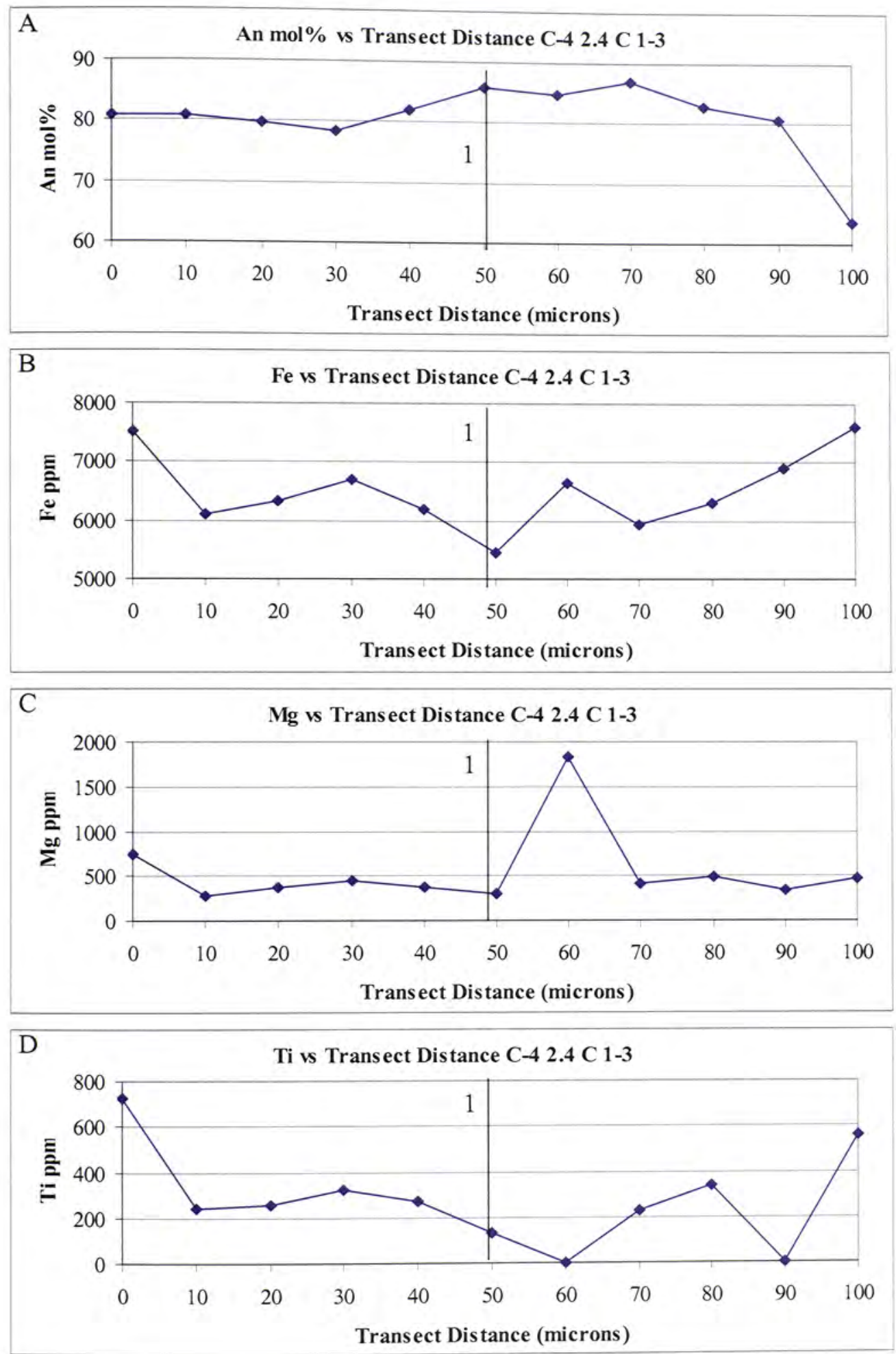


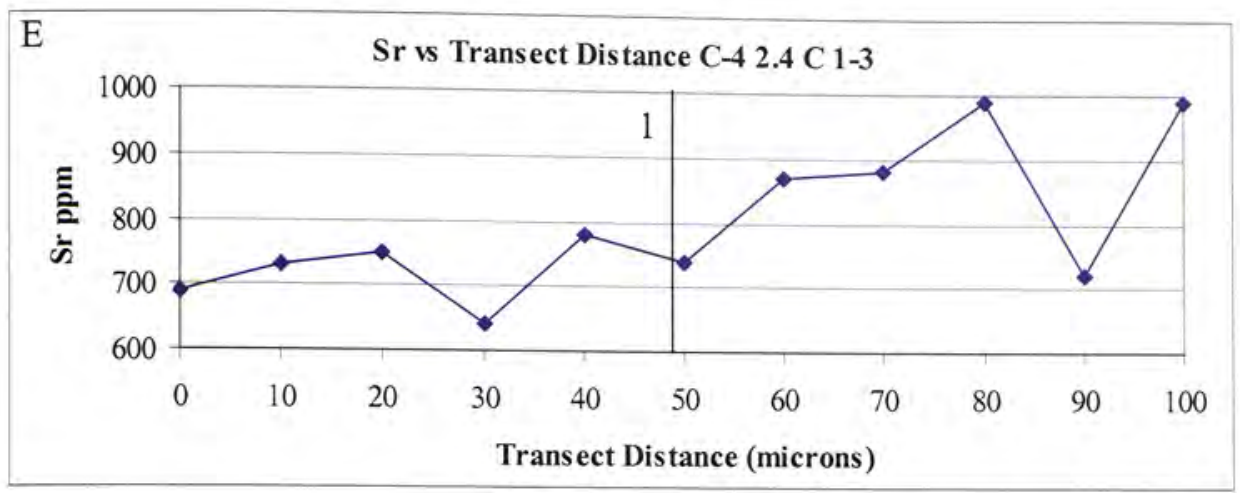

Figure 80: Trace element transect comparison with An mol\% in basaltic andesite.

Representative trace element transects of $\mathrm{Fe}, \mathrm{Mg}$, $\mathrm{Ti}$, and $\mathrm{Sr}$ versus $\mathrm{An} \mathrm{mol} \%$ in plagioclase in basaltic andesite samples. One An mol\% spike, labeled 1, of greater than 5 mol\% has been correlated with respective points on the trace element transects. This example shows all four trace elements decreasing with increasing An mol\%. The complete data set showing trace element comparisons with An mol\% spikes in basaltic andesite is in appendix D. 


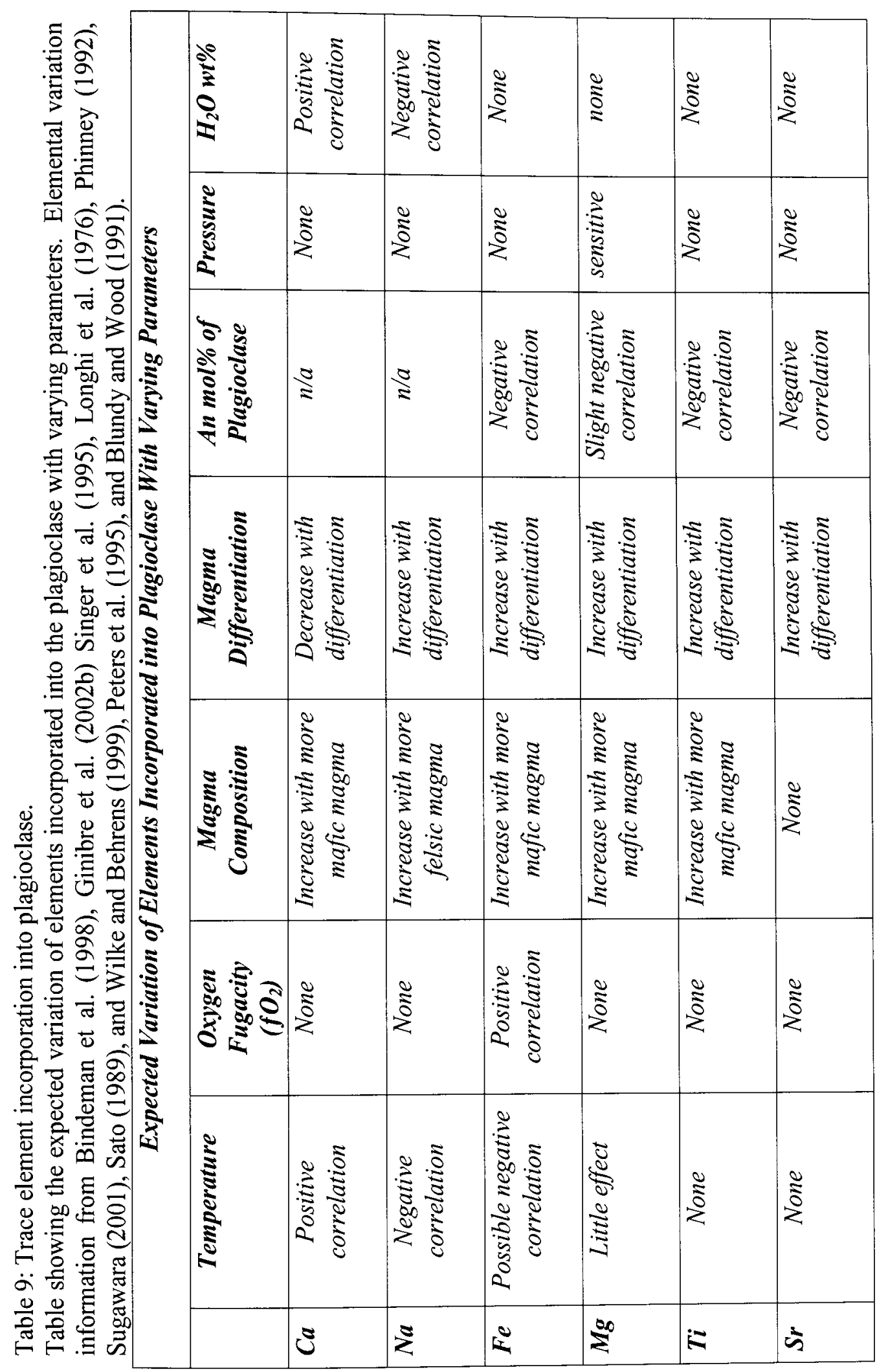



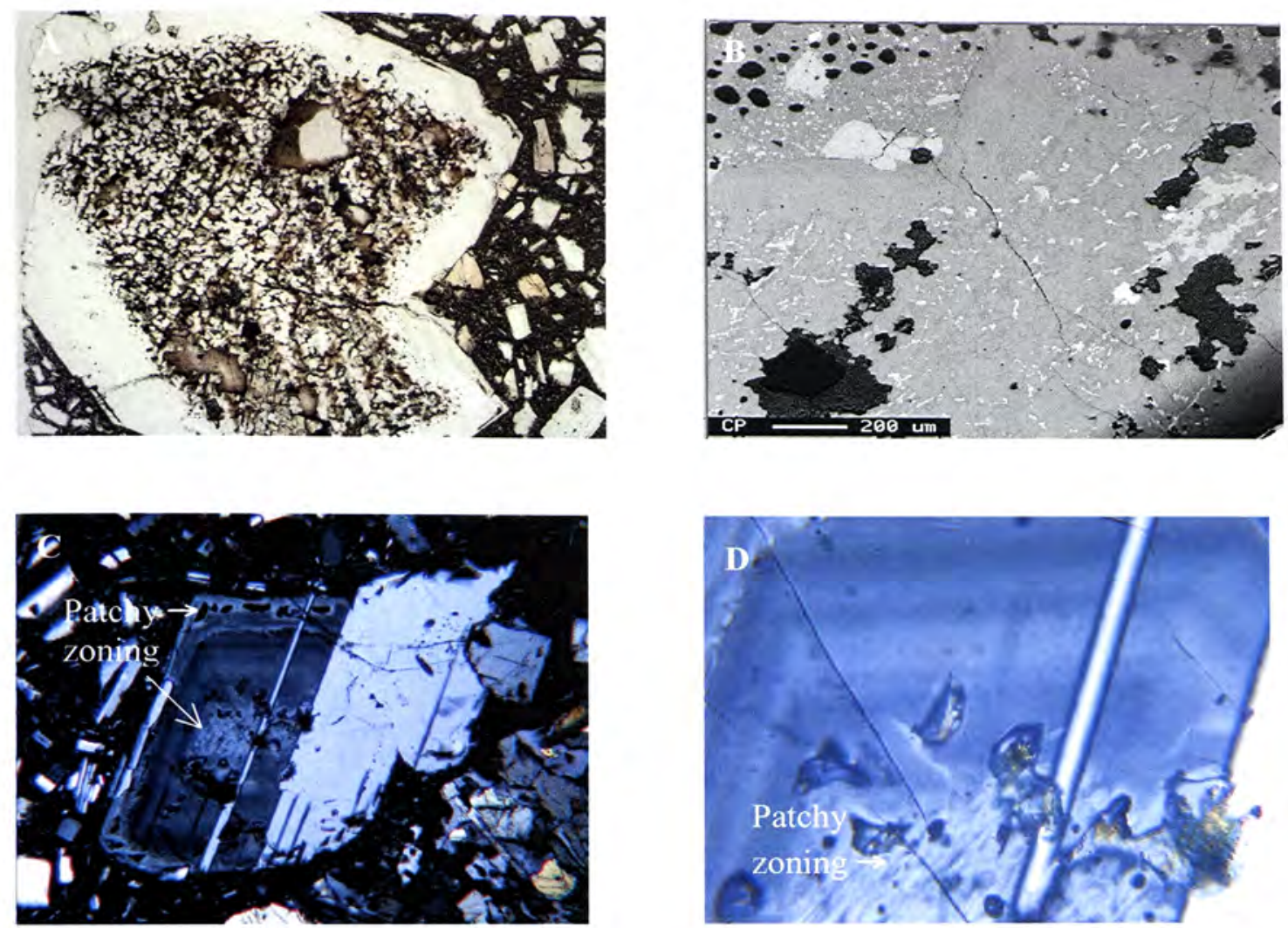

Figure 81: Photomicrographs of plagioclase textures.

Photomicrographs and back scattered electron image showing sieve textures and patchy zoning. A and B show sieve textured plagioclase. $\mathrm{A}$ is a photomicrograph taken in plane polarized light showing sieve textures in the core of a plagioclase grain. Field of view is $2.8 \mathrm{~mm}$. B is a backscattered image of the same plagioclase grain. C and D are showing patchy zoning in plagioclase. Both are photomicrographs taken in cross polarized light of the same plagioclase grain. The field of view for C is $2.8 \mathrm{~mm}$, and for D is $1.1 \mathrm{~mm}$. 

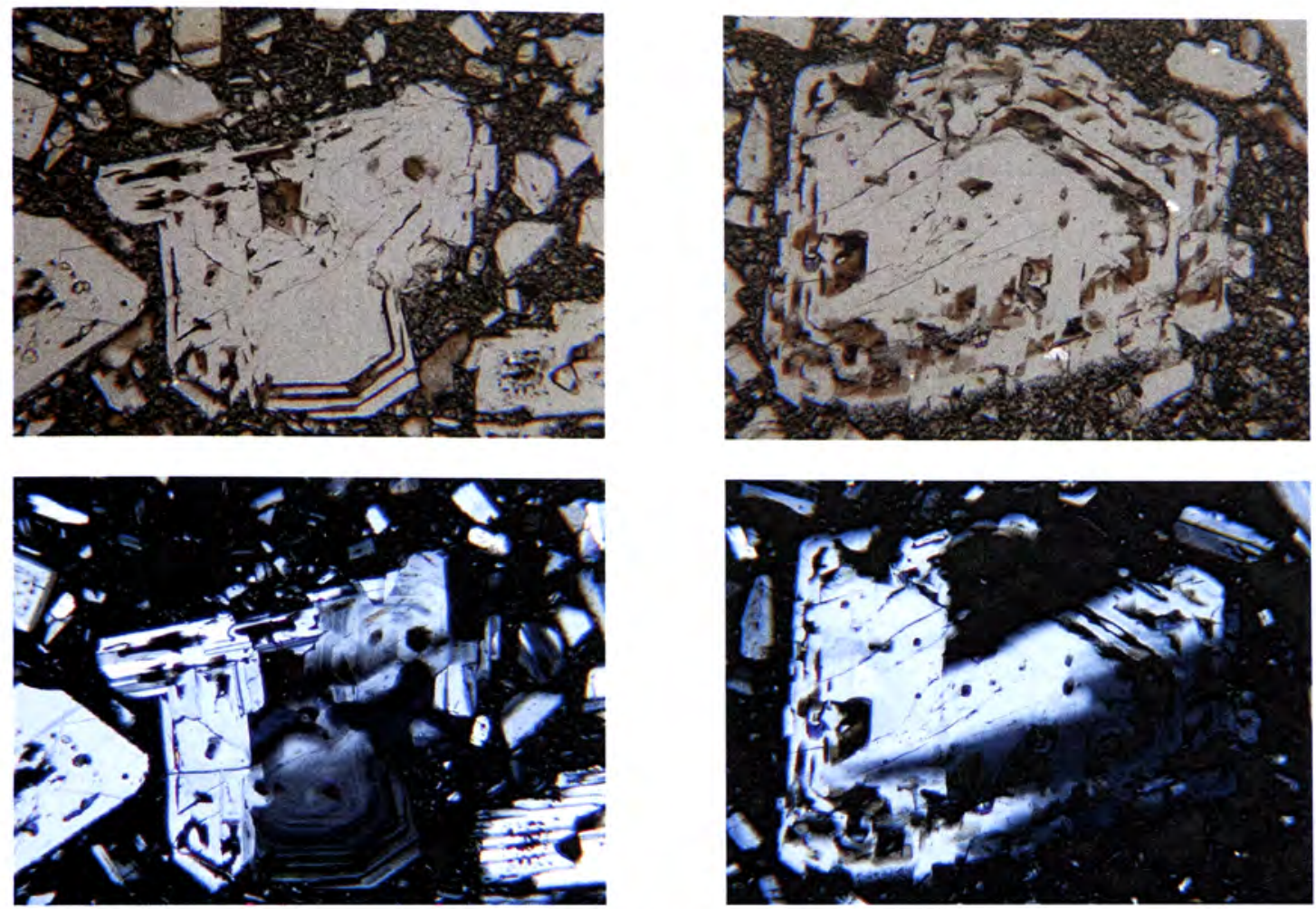

Figure 82: Photomicrographs of volcanic glass in plagioclase.

Photomicrographs in plane and cross polarized light of two plagioclase grains with glass confined within specific growth zones. Field of view is $2.8 \mathrm{~mm}$. 


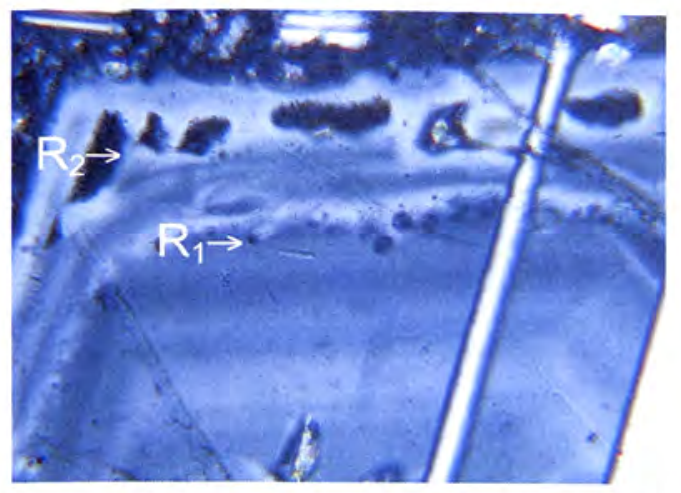

Figure 83: Photomicrograph of major plagioclase resorption zones.

Photomicrograph in cross polarized light showing two major resorption zones. Field of view $1.1 \mathrm{~mm}$.

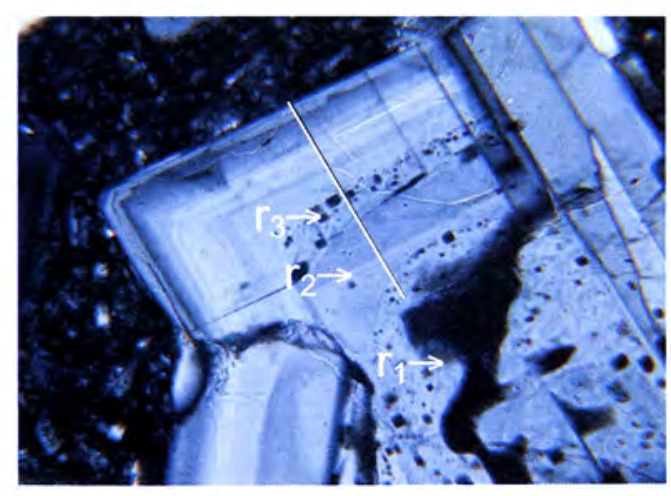

Figure 84: Photomicrograph of minor plagioclase resorption zones.

Photomicrograph in cross polarized light showing three minor resorption zones. Field of view $1.1 \mathrm{~mm}$. 

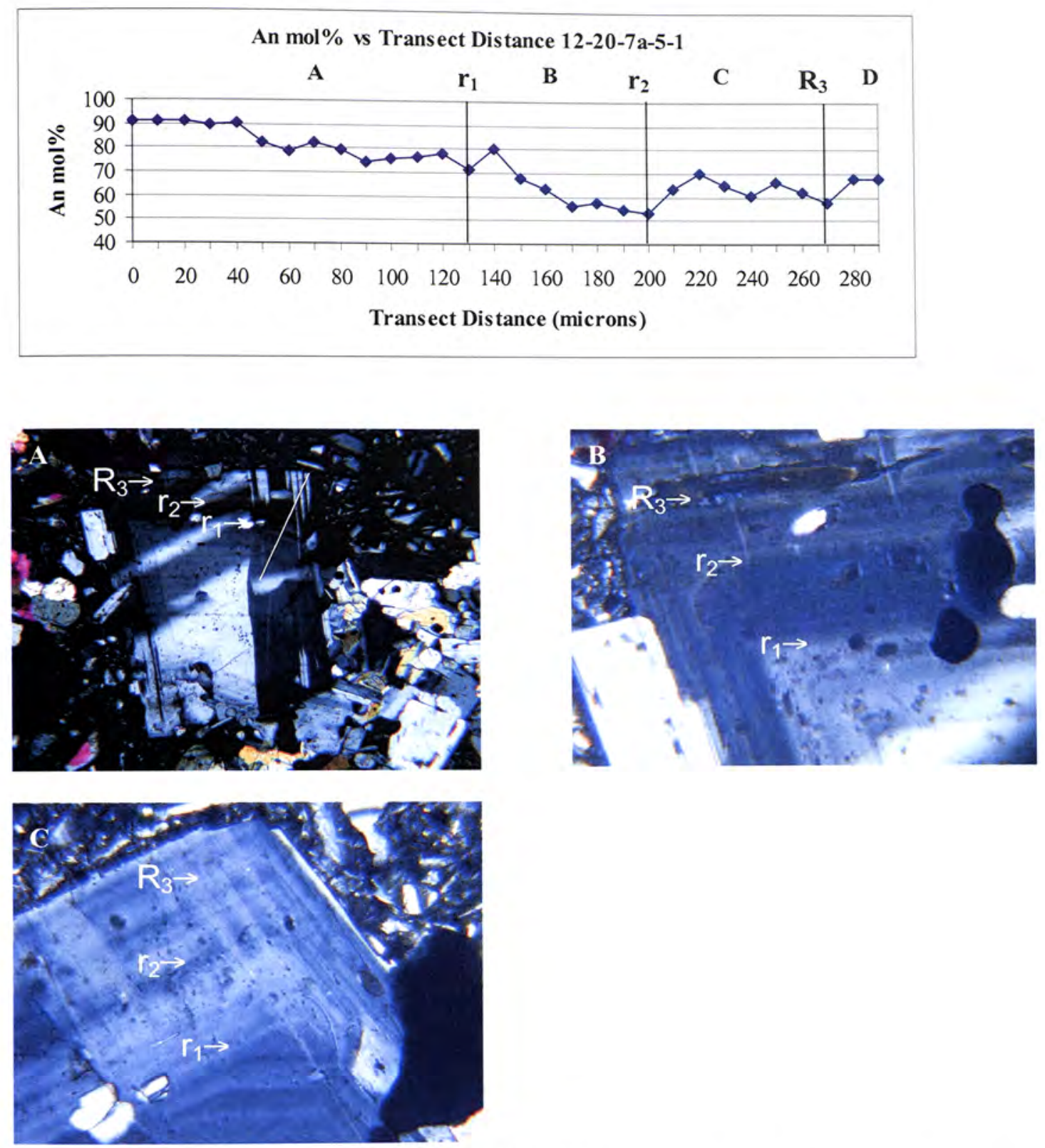

Figure 85: Plagioclase resorption and growth zones.

Representative plagioclase transect (transect line indicated) with major and minor resorption zones indicated $\left(\mathrm{r}_{1}, \mathrm{r}_{2}\right.$, and $\left.\mathrm{R}_{3}\right)$. Resorption zones are followed by $\mathrm{An} \mathrm{mol \%}$ spikes. A, B, C, and D are four growth zones representing time between resorption events. Growth zones A and B both show a sharp drop in An mol\% of $10 \%$ and $12 \%$ respectively. Photomicrographs- A: Showing the location of the electron microprobe transect on plagioclase crystal corresponding to transect 12-20-7a-5-1, B: Location of major $(\mathrm{R})$ resorption zone, and C: Location of minor (r) resorption zones. A: Field of view is $2.8 \mathrm{~mm}, \mathrm{~B}, \mathrm{C}$ : Field of view $1.1 \mathrm{~mm}$. 


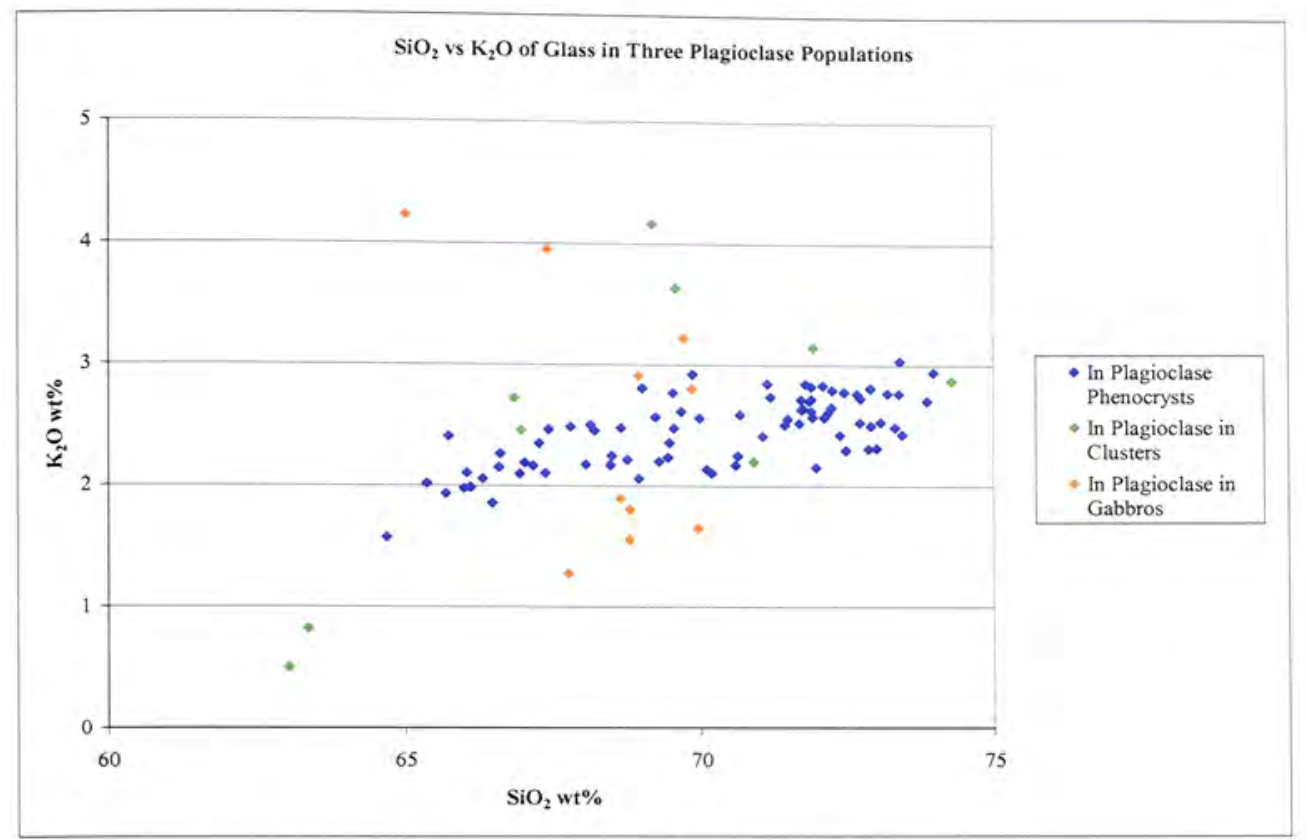

Figure 86: $\mathrm{SiO}_{2}$ versus $\mathrm{K}_{2} \mathrm{O}$ of glass in plagioclase.

Plot of $\mathrm{SiO}_{2}$ wt $\%$ versus $\mathrm{K}_{2} \mathrm{O}$ wt $\%$ of glass trapped within plagioclase phenocrysts and plagioclase grains in cumulate xenoliths and crystal clusters.

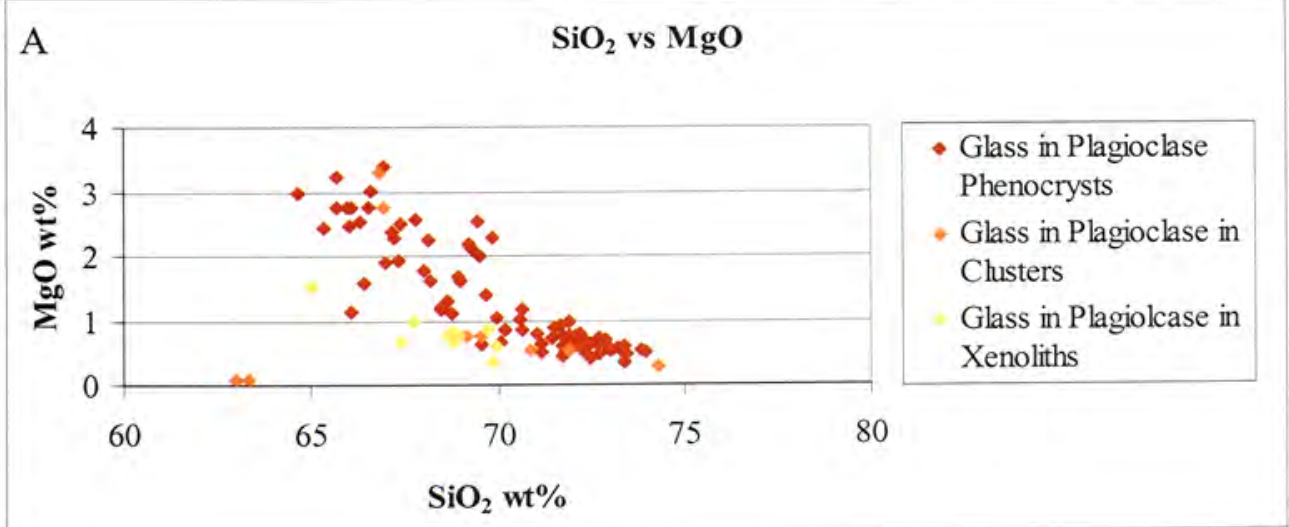



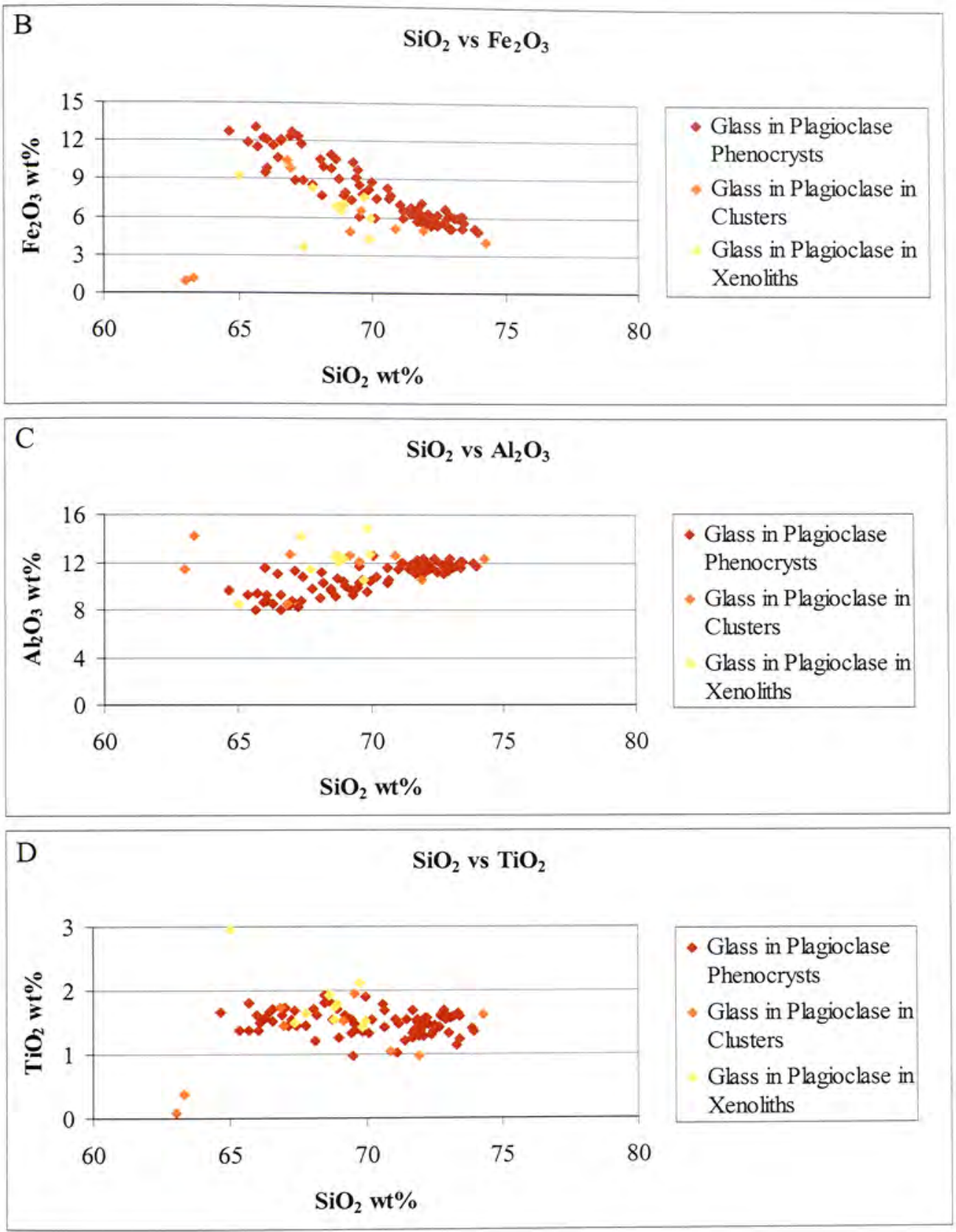

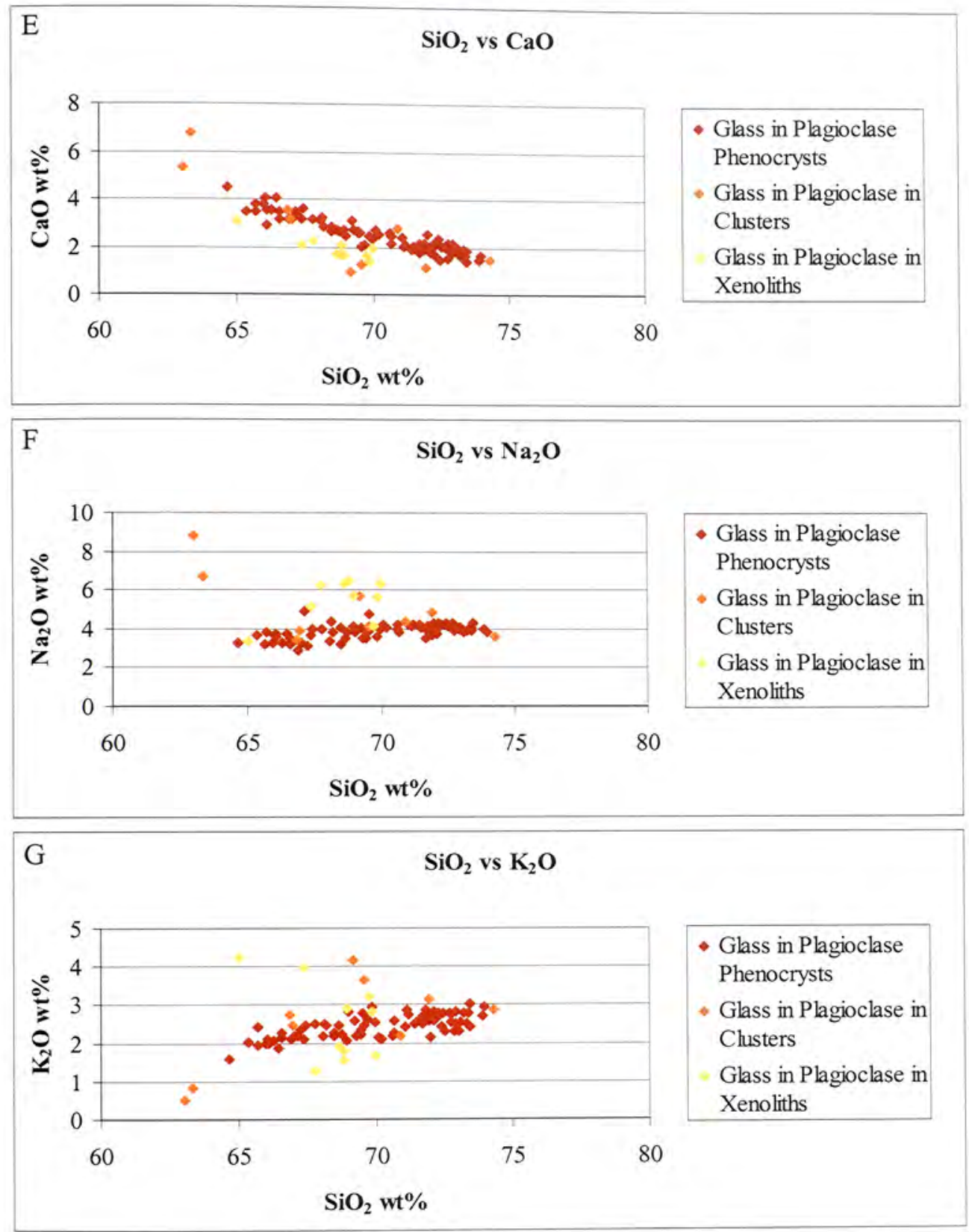


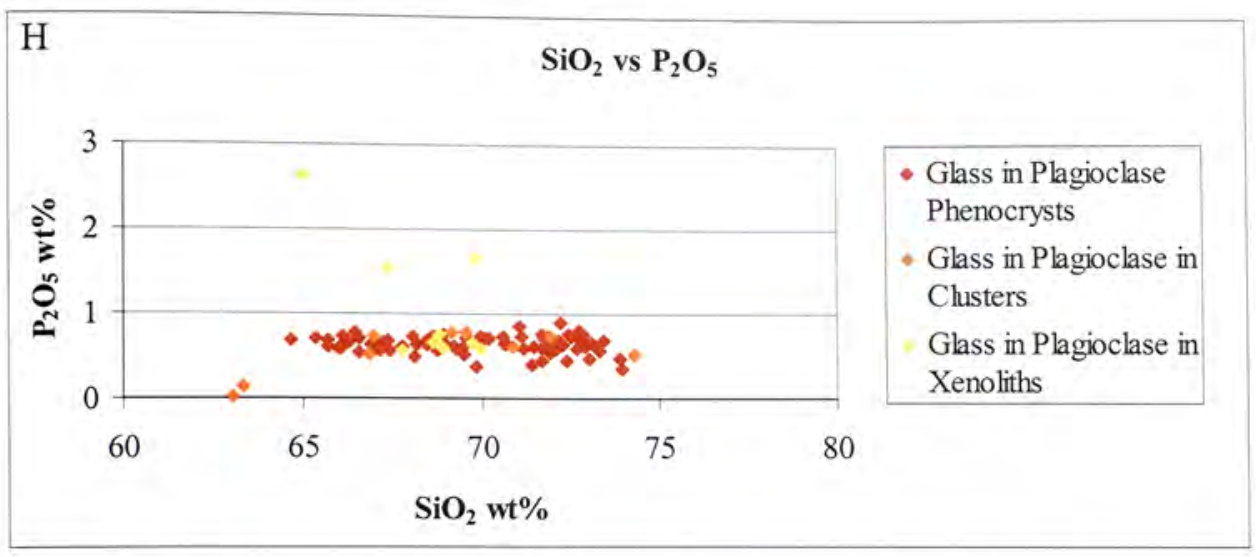

Figure 87: $\mathrm{SiO}_{2}$ versus oxides in bulk glass analysis in plagioclase phenocrysts.

Plot comparing wt $\%$ oxides $\left(\mathrm{MgO}, \mathrm{Fe}_{2} \mathrm{O}_{3}, \mathrm{Al}_{2} \mathrm{O}_{3}, \mathrm{TiO}_{2}, \mathrm{CaO}, \mathrm{Na}_{2} \mathrm{O}, \mathrm{K}_{2} \mathrm{O}\right.$, and $\mathrm{P}_{2} \mathrm{O}_{5}$ ) versus $\mathrm{wt} \% \mathrm{SiO}_{2}$ for bulk analysis of glass trapped in plagioclase phenocrysts, plagioclase in crystal clusters, and plagioclase in cumulate xenoliths. Glass analyses have been screened for crystal structure, however outlying data points may be overlap, due to use of a defocused beam on the electron microprobe, between the glass and host crystals or post entrapment crystals.

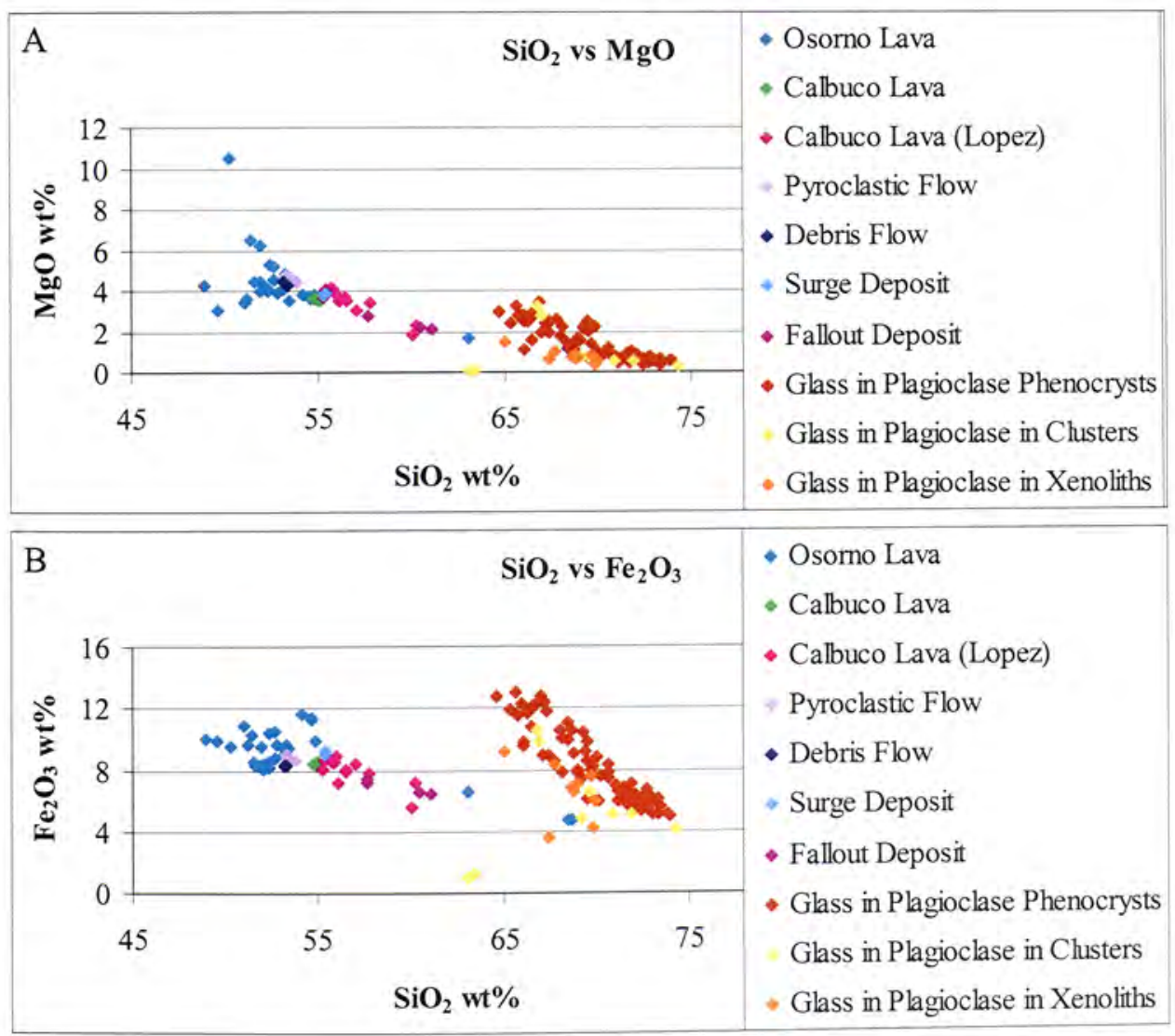



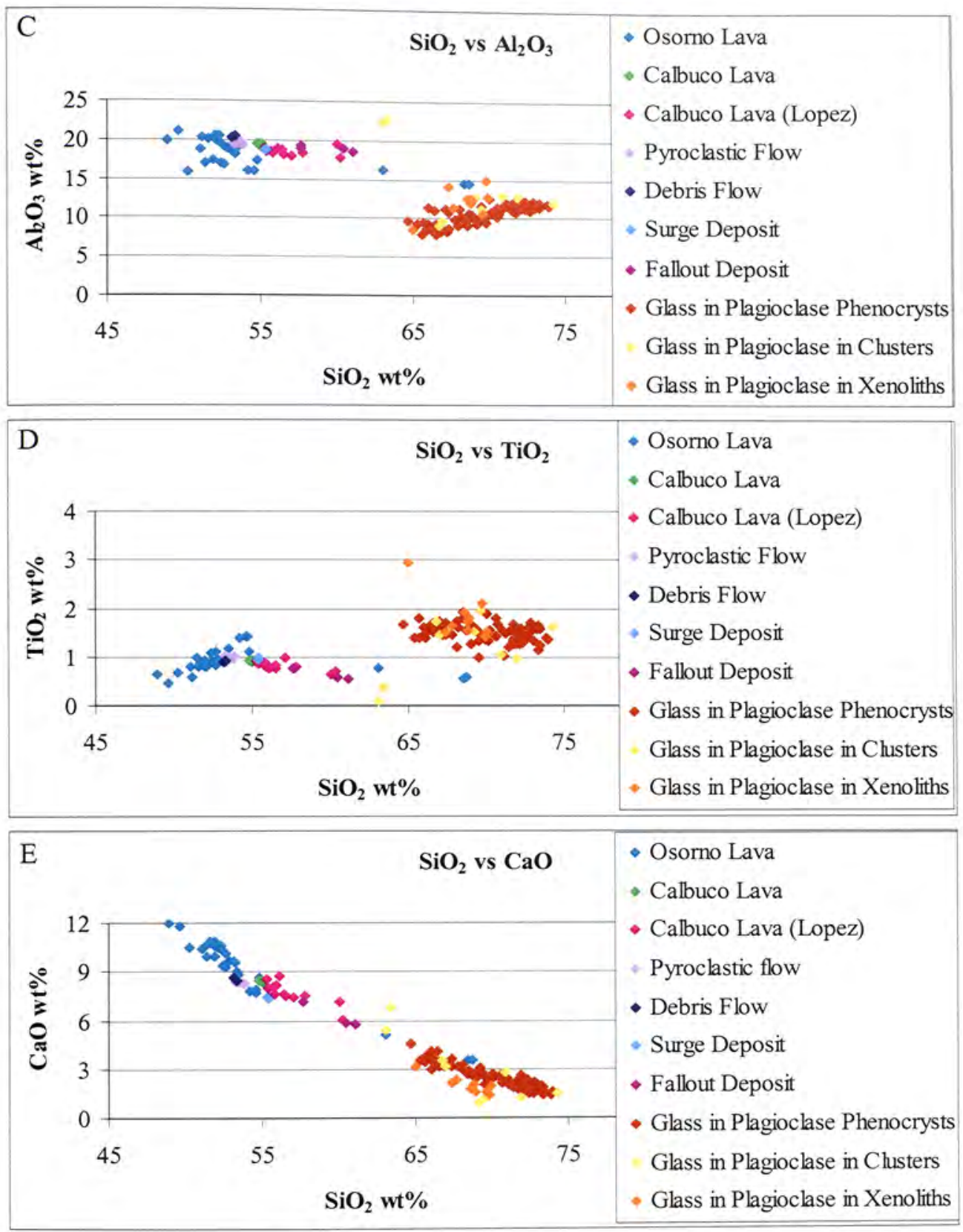

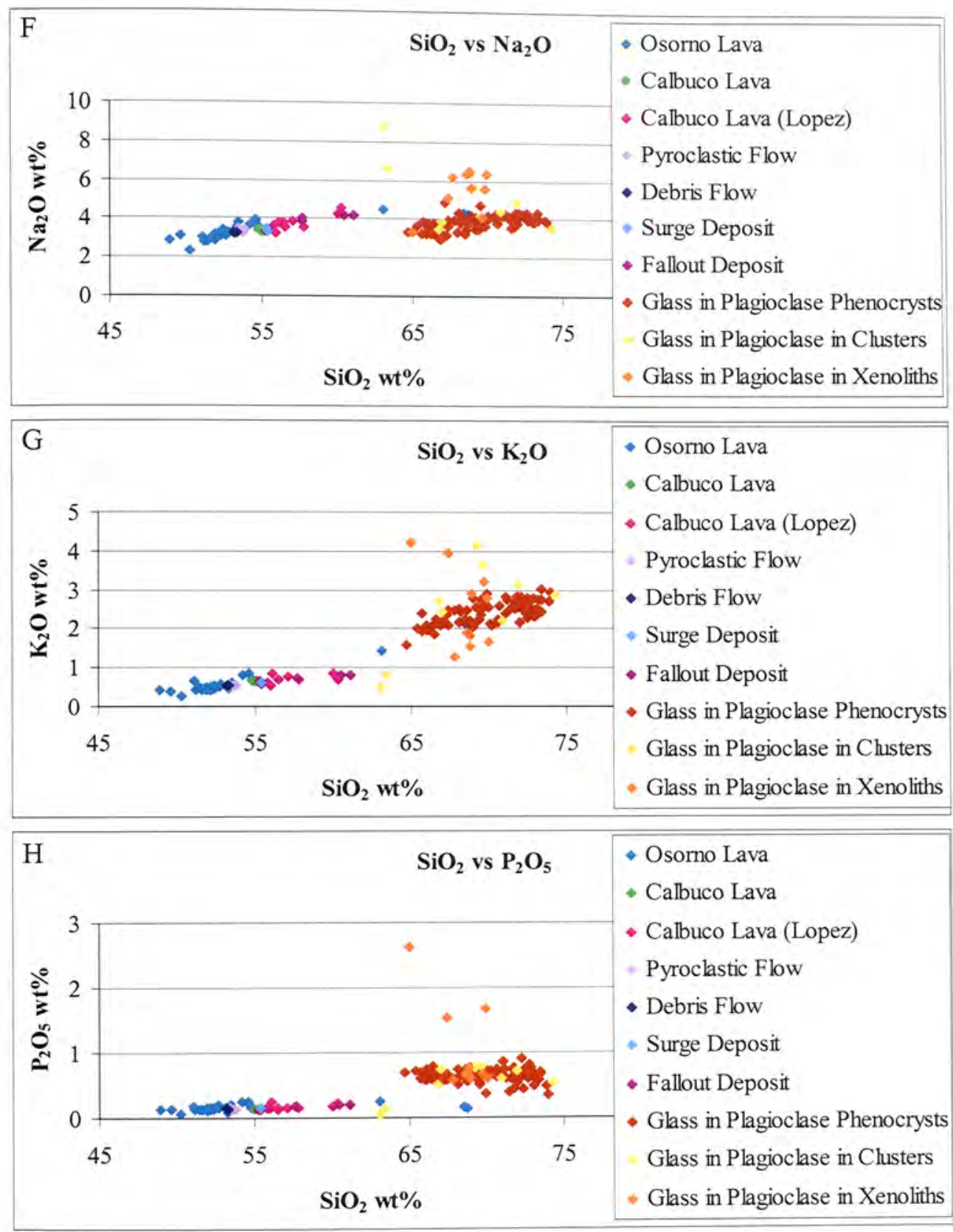

Figure 88: $\mathrm{SiO}_{2}$ versus oxides of bulk glass analysis in all plagioclase populations.

Plot comparing wt $\%$ oxides $\left(\mathrm{MgO}, \mathrm{Fe}_{2} \mathrm{O}_{3}, \mathrm{Al}_{2} \mathrm{O}_{3}, \mathrm{TiO}_{2}, \mathrm{CaO}, \mathrm{Na}_{2} \mathrm{O}, \mathrm{K} 2 \mathrm{O}\right.$, and $\left.\mathrm{P}_{2} \mathrm{O}_{5}\right)$ versus $\mathrm{wt} \% \mathrm{SiO}_{2}$ for bulk analysis of glass trapped in plagioclase phenocrysts, plagioclase in crystal clusters, and plagioclase in cumulate xenoliths with bulk analyses of Calbuco and Osorno lavas, Calbuco pyroclastic and debris flows, and Calbuco fallout and surge deposits. Glass analyses have been screened for crystal structure, however outlying data points may be overlap, due to use of a defocused beam on the electron microprobe, between the glass and host crystals or post entrapment crystals. 


\section{Chapter 7. Discussion}

\subsection{Introduction}

This chapter discusses hornblende crystallization and breakdown, as well as the magmatic processes recorded in plagioclase crystals. The discussion of hornblende crystallization includes the gabbroic xenoliths, chemical stability of the hornblende crystals, Cr content comparisons with hornblende from Volcán San Pedro, and the mineral make-up of hornblende breakdown reaction products. Discussion of specific condition changes in the magma chamber recorded in the plagioclase includes magma mixing, magmatic temperature changes, changes in dissolved $\mathrm{H}_{2} \mathrm{O}$ content of the magma, magma chamber convection driven circulation, magma chamber pressure changes, and plagioclase equilibrium crystallization kinetics. This chapter also contains an overview of the magmatic properties of Calbuco andesite and basaltic andesite, including mineral stability, temperature, pressure, dissolved water content, and magmatic density, as well as an overview of the magmatic processes inside Calbuco, including crystal fractionation, magma chamber convection, and magma recharge.

\subsection{Hornblende Crystallization}

\section{2a Gabbroic Xenoliths}

An understanding of the origin of the gabbroic xenoliths found in Calbuco Volcano's eruptive products is important to an understanding of magmatic processes there. A primary question is whether they are true xenoliths (i.e. fragments of country rock) or whether they are sections of a related cumulate pile entrained in the magma. If they are part of the cumulate pile, they provide information about magmatic evolution of Calbuco lava. If they are xenoliths, they are potential contaminants for the magma. In 
addition to the gabbroic xenoliths, there are also granulite xenoliths which have been previously determined to be country rock incorporated within the magma (Hickey-Vargas et al., 1995). It has also been found that Calbuco has been influenced by crustal contamination (López-Escobar et al., 1995).

\section{1a.i Evidence for Gabbroic Xenoliths Being Cumulate}

Gabbroic xenoliths consist of plagioclase, orthopyroxene, minor clinopyroxene, olivine, hornblende, magnetite \pm ilmenite and accessory phlogopite and apatite, which is the same overall mineral assemblage as the phenocryst mineral assemblage in the lava. This fact alone is not compelling evidence that these gabbroic xenoliths are cumulate since the possibility exists that they could be country rock with a similar igneous origin, and therefore the same mineral assemblage. In order for the gabbros to be cumulate, they must have crystallized from the magma at an earlier time and would therefore be chemically similar to the phenocrysts in the lava. Analysis of the mineral phases shows that the major element chemistry of the coarse grains overlaps that of the individual hornblende, orthopyroxene, clinopyroxene, olivine, and magnetite phenocrysts, and the cores of zoned plagioclase phenocrysts (Figure 89, Figure 90, Figure 91, Figure 92, Figure 93). The Mg-number of all individual mafic phases can be compared (Figure 94) and used to estimate how magnesian the magma was from which the minerals crystallized. This comparison shows that there is some variation in the upper and lower ends of the Mg-number ranges, particularly for clinopyroxene and phlogopite, but that the overall $\mathrm{Mg}$-number ranges of the mafic phases in the gabbroic xenoliths overlaps with that of the phenocrysts. The noted limited Mg-number range in clinopyroxene is likely caused by its low modal abundance. The relatively high $\mathrm{Mg}$-number range of phlogopite 
may also be caused by low modal abundance but could also indicate its formation accompanying the breakdown of hornblende. López-Escobar et al. (1995) and HickeyVargas et al. (1995) also concluded that the gabbroic xenoliths are cumulate based on major element modeling of bull rock data and isotopic constraints.

\section{2b Hornblende Formation by Primary Crystallization}

The conditions required for hornblende crystallization in calc-alkaline magma are the presence of water, high pressure, and high $\mathrm{Na}$ contents of the magma. Figure 95 shows that all of the whole rock analyses of andesite and basaltic andesite, and microprobe analyses of glass trapped in plagioclase and pyroxene phenocrysts and cumulates, with the exception of only a few points, have $\mathrm{Na}_{2} \mathrm{O}$ wt $\%$ greater than $3 \%$. The few points which have low $\mathrm{Na}_{2} \mathrm{O}$ are also associated with the lowest of the $\mathrm{SiO}_{2}$ ranges found in any eruptive product from Calbuco, basalt, and significantly higher $\mathrm{FeO}$ and $\mathrm{MgO}$. Therefore, nearly all Calbuco liquid compositions have greater than $3 \% \mathrm{Na}_{2} \mathrm{O}$. Exchange $\mathrm{Kd}$ values for $\mathrm{Al}-\mathrm{Si}$ in hornblende have been experimentally derived for compositions of high- $\mathrm{Al}_{2} \mathrm{O}_{3}$ basalts through high $\mathrm{SiO}_{2}$ rhyolites (Sisson and Grove, 1993a). Exchange Kd values for Fe-Mg partitioning between hornblende and melt has been determined for high- $\mathrm{Al}_{2} \mathrm{O}_{3}$ basalt through aluminous andesite (Sisson and Grove, 1993a). Figure 96 and Figure 97 are plots showing the exchange of molar Al-Si and Fe-

$\mathrm{Mg}$ respectively between the analyzed hornblende phenocryst and whole rock data. In both instances Calbuco hornblende values coincide with experimentally derived $\mathrm{Kd}$ values. Therefore, these partition coefficients show that hornblende is in equilibrium with melt from Calbuco, which adds to the evidence for hornblende crystallization from the magma. 
According to Costa et al. (2002), gabbroic, hornblende bearing, cumulate xenoliths are commonly found entrained in arc-related eruptive products while hornblende phenocrysts are rare. Based on the scarcity of hornblende phenocrysts, they suggested that hornblende in cumulate xenoliths does not crystallize from the magma but rather forms as a reaction product from the interaction of a cumulate pile and an evolved melt \pm aqueous fluid. As evidence for this, they cite the high modal abundance of hornblende, the high $\mathrm{Cr}_{2} \mathrm{O}_{3}$ wt\% and $\mathrm{Mg}$-number of the hornblende and phlogopite crystals, and the high $\mathrm{Na}_{2} \mathrm{O}$ wt $\%$ of the phlogopite in the cumulate gabbroic xenoliths entrained in the andesite to dacite lava flows of Volcán San Pedro.

In some respects, hornblende and phlogopite found in the cumulate gabbroic xenoliths from Calbuco Volcano differ from those found at Volcán San Pedro. $\mathrm{Cr}_{2} \mathrm{O}_{3}$ weight percentages of both hornblende and phlogopite are not as high as those reported by Costa et al. (2002), with the exception of a few anomalously high points. The overall $\mathrm{Cr}_{2} \mathrm{O}_{3}$ values reported by Costa et al. (2002) are 0.9-1.2 wt \% for hornblende and 0.4-0.6 wt $\%$ for phlogopite. Hornblende from Calbuco has $\mathrm{Cr}_{2} \mathrm{O}_{3}$ values of $0.002-0.08 \mathrm{wt} \%$ for hornblende and $0.02 \mathrm{wt} \%$ for phlogopite, which are significantly lower. The few points with high $\mathrm{Cr}_{2} \mathrm{O}_{3}$ weight percentages, which have up to approximately ten times higher wt $\% \mathrm{Cr}_{2} \mathrm{O}_{3}$, are in sample 12-19-18 which is made up of only one large hornblende grain poikilitically enclosing all other minerals present. Numerous analyses were taken of this one hornblende grain, all of which are low in $\mathrm{Cr}_{2} \mathrm{O}_{3}$, therefore, these few $\mathrm{Cr}$-rich points are probably due to Cr-rich micro-inclusions.

$\mathrm{Kd}$ values for the partitioning of $\mathrm{Cr}$ between hornblende and melt can be used to determine whether equilibrium existed between hornblende and both andesite and 
basaltic andesite from Calbuco, as well as the potential parent basaltic andesite from Osorno. $\mathrm{Kd}$ values for $\mathrm{Cr}$ were calculated from existing hornblende and lava whole rock analyses. Table 10 shows a comparison of these values with published values from Sisson (1994), Luhr and Carmichael (1980), and Dostal (1983). The range of calculated values for partitioning of $\mathrm{Cr}$ between hornblende and andesite from Calbuco match the ranges of values represented by Sisson (1994) and Luhr and Carmichael (1983). The range of calculated values for basaltic andesite from Osorno and hornblende also match published value ranges from Sisson (1994) and Dostal (1983). The range of calculated values for basaltic andesite from Calbuco, which have not been found with hornblende, do not match published values. Based on the outcome of these calculations, the high $\mathrm{Cr}$ contents of the hornblende reported by Costa et al (2002) would need to have crystallized from magma with higher $\mathrm{Cr}$ contents than the $\mathrm{Cr}$ concentrations of Calbuco andesite.

The overall Mg-number range for San Pedro hornblende was 64-80; 70-84 for phlogopite (Costa et al., 2002). These values overlap the Mg-numbers for these minerals from Calbuco; hornblende ranges from 65-71 and phlogopite from 77-79. The high $\mathrm{Na}_{2} \mathrm{O}$ wt $\%$ in phlogopite is also found in the cumulate xenoliths containing phlogopite from Calbuco. Costa et al. (2002) report 1.13-4.08 wt\% $\mathrm{Na}_{2} \mathrm{O}$ which overlaps the 1.34-1.94 $\mathrm{wt} \%$ from Calbuco. However, the phlogopite found in Calbuco is low in modal abundance and restricted to gabbroic xenoliths which have undergone enough interior melting to have acquired a metamorphic (granulitic) texture. Based on this and on their high Mg-number range, the phlogopite has probably crystallized as a result of hornblende crystals breaking down. The appropriate hornblende compositions (Al-Si, Fe-Mg, and $\mathrm{Cr}$ ), appropriate $\mathrm{Na}_{2} \mathrm{O}$ contents of Calbuco lavas and melt inclusions, and the presence of 
hornblende phenocrysts are compelling evidence that Calbuco magma has crystallized hornblende. Despite the claim that few hornblende phenocrysts are found in arc-related volcanism (Costa et al., 2002), hornblende phenocrysts are found in the andesitic lava from Calbuco, albeit a low modal abundance. An alternate explanation for their low abundance is that hornblende crystallized at depth and decomposed during decompression, either in a shallow magma chamber or during eruption.

López-Escobar et al. (1995) also concluded that hornblende crystallized from Calbuco magma. They concluded that the lower than expected $\mathrm{K}_{2} \mathrm{O}$ contents of Calbuco andesites actually reflect abnormally high $\mathrm{SiO}_{2}$ abundances at a given extent of crystallization as fractional crystallization of hornblende drives the residual liquid in the direction of $\mathrm{SiO}_{2}$ enrichment (Sisson and Grove, 1993a; Cawthorn and O'Hara, 1976; Pichavant et al., 2002; López-Escobar et al., 1995; Yagi and Takeshita, 1987; Allen and Boettcher, 1983; Foden and Green, 1992). Consistent with this, López-Escobar et al. (1995) concluded that the $\mathrm{SiO}_{2}$ enrichment trend seen at Calbuco was evidence for fractionation of approximately $30 \%$ of the hornblende gabbro assemblage from the magma (Figure 10 from chapter 2).

\section{2c Breakdown Reaction of Hornblende}

Hornblende phenocrysts and coarse grained hornblende in cumulate xenoliths are undergoing decompression melting during magma ascent due to decreasing pressure. There are three types of reaction products found, 1) a fine to medium grained "gabbroic type" composed of anhedral plagioclase, orthopyroxene, clinopyroxene, and magnetite, 2) a microcrystalline "black type" product composed of minute iron ore and pyroxene minerals (Garcia and Jacobson, 1979) and 3) reaction rims on hornblende phenocrysts. 
Garcia and Jacobson (1979) interpreted the "gabbroic type" reaction products to be caused by dehydration of hornblende as a result of degassing of the magma chamber, and the "black type" hornblende breakdown as products of dehydrogenation and oxidation during extrusion due to decreased $\mathrm{H}_{2} \mathrm{O}$ fugacity and increased oxygen fugacity relative to hydrogen fugacity. The "gabbroic type" is also associated with patches of microcrystalline "black type" reaction products. Two types of reaction rims occur, a microcrystalline black rim and a medium-fine grained white rim consisting of plagioclase, pyroxene, and rare oxides. Opacite rims are the result of opacitization of the hornblende, a process which begins around the outside of the crystal and along fractures and cleavage planes and can completely replace the hornblende crystal, and is characterized by increasing amounts of fine-grained magnetite and anhydrous minerals (Rutherford and Devine, 2003; Devine et al., 1998b). Rutherford and Devine (2003) and Devine et al. (1998b) have interpreted the cause of opacite rims and opacitization to be near surface oxidation of the magma. Based on the fact that the "black type" reaction products described by Garcia and Jacobson (1979) have the same appearance, texture, and mineral make-up as opacite rims, and that both reaction products have been interpreted to result from the same process, "black type" hornblende breakdown products are the same as opacite rim reaction products and the "black type" reaction product is extensive opacitization of the entire crystal. White reaction rims are produced as a result of decompression of the hornblende during magma ascent (Rutherford and Devine, 2003; Devine et al., 1998a, b). Hornblende phenocryst breakdown typically results in reaction phases forming hornblende pseudomorphs which may or may not contain remnants of the original hornblende. Evidence of distinct rims is preserved in the microcrystalline 
pseudomorph. Coarse grained hornblende in the cumulate xenoliths is not typically fully broken down and opacitization is found occurring throughout or rimming the crystal.

In general, the mineral assemblage of the microcrystalline breakdown products consists of plagioclase, clinopyroxene, orthopyroxene, pigeonite or sub-calcic augite, olivine, magnetite \pm ilmenite; however, individual mineral associations can vary (Table 4 and Table 5, chapter 5). Analyses have shown that there are 13 different mineral assemblages out of 22 individual opacite patches throughout gabbroic xenoliths and phenocrysts:

1) $\mathrm{Plag}+\mathrm{Cpx}+$ Low-Ca $\mathrm{Cpx}+\mathrm{Opx}+\mathrm{Ol}+\mathrm{Mag}$

2) $\mathrm{Plag}+\mathrm{Cpx}+$ Low-Ca Cpx + Mag

3) $\mathrm{Plag}+\mathrm{Cpx}+\mathrm{Pig}+\mathrm{Ol}+\mathrm{Mag} \pm \mathrm{Ilm}$

4) $\mathrm{Plag}+\mathrm{Cpx}+\mathrm{Pig}+\mathrm{Opx}+\mathrm{Ol}+\mathrm{Mag}$

5) Plag + Pig + Low-Ca Cpx + Mag

6) $\mathrm{Plag}+\mathrm{Cpx}+\mathrm{Pig}+\mathrm{Opx}+\mathrm{Mag}$

7) Plag + Cpx + Opx + Mag

8) $\mathrm{Plag}+\mathrm{Cpx}+\mathrm{Ol}+\mathrm{Mag}$

9) Plag + Low-Ca Cpx + Mag

10) $\mathrm{Plag}+\mathrm{Cpx}+\mathrm{Mag} \pm \mathrm{Ilm}$

11) $\mathrm{Plag}+\mathrm{Ol}+\mathrm{Mag}$

12) Plag + Opx + Mag

13) Plag + Mag.

The variability of mineral assemblages formed by hornblende breakdown could be an artifact of the small size ( $<5$ microns) of the individual minerals and the imaging 
resolution and spot size of the electron microprobe at FIU. Due to the fact that the reaction products are mostly too small to see with back-scattered imaging on the electron microprobe at FIU, it is not possible to know if the phases analyzed represent all the phases present in any one patch of opacite, and it is possible that it is not representative. Because of this uncertainty of the analysis, it is assumed that all of the phases found (plagioclase, clinopyroxene, orthopyroxene, pigeonite or sub-calcic augite, olivine, magnetite \pm ilmenite) are the collective result of hornblende breakdown. López-Escobar et al. (1995) reported that hornblende was breaking down to plag $+\mathrm{cpx}+$ mag, however this reaction formed "gabbroic type" reaction products rather than opacitic products. Hornblende breakdown reactions have been identified for other volcanic centers and reported mineral assemblages are similar to assemblages listed above. For hornblende in dacite from the Cascade Range, Garcia and Jacobson (1979) report a breakdown reaction of Amph $\rightarrow$ plag $+\mathrm{cpx}+$ opx + mag ("gabbroic type" reaction products). Reaction rims have been reported for hornblende from Soufrière Hills, Mount Pelée, and Colima. At Soufrière Hills the hornblende was in andesite and the breakdown reaction was Hbld $\rightarrow$ cpx + opx + plag + mag + melt (Devine et al., 1998a, b). Hornblende is found in andesite and high-alumina basalt at Mount Pelée and the breakdown reaction reported is Hbld $\rightarrow$ plag + opx + mag (Pichavant et al., 2002). Hornblende in andesite from Colima has the following breakdown reaction: Amph $\rightarrow \mathrm{cpx}+\mathrm{Fe}-\mathrm{Ti}$ oxide (Mora et al., 2002). Experimental hornblende breakdown has also produced a similar reaction of Amph $\rightarrow$ ol $+\operatorname{cpx}+\operatorname{plag}+\mathrm{L} \pm \mathrm{V}$ for hornblende in high-alumina basalt (Foden and Green, 1992) Due to the size of the breakdown phases, it is also not possible to identify the presence or absence of glass (a liquid phase) associated with the reaction or any subsequent reactions 
taking place among the reaction products. Since hornblende is hydrous, the breakdown reaction will release water from the mineral which could result in a separate vapor phase present in the breakdown reaction products in addition to the mineral phases or initiate melting. The presence of a liquid and/or vapor could also initiate a second reaction within the reaction products; the olivine could react with the liquid to form orthopyroxene and oxide minerals.

Crystal clots have been reported by several people and one interpretation of their formation has been as the reaction products of hornblende breakdown (Castro and Stephens, 1992; Scarfe and Fujii, 1987; Garcia and Jacobson, 1979; and Sail et al., 1998; Amma-Miyasaka and Nakagawa, 2003). Clusters of crystals, which do vary in mineral associations but generally consist of plagioclase, orthopyroxene, clinopyroxene, olivine, and magnetite \pm glass, are found entrained in the lavas. Although the mineral assemblage in these clusters is similar to that found in both the "black type" and "gabbroic type" products, the crystal clusters are distinctly different. Contrary to the microcrystalline and medium grain sizes found in the two hornblende reaction products, the crystal clusters are predominantly coarse grained. The occasional presence of zoned plagioclase crystals incorporated in the center of these clusters is compelling evidence that they have not formed by the breakdown of hornblende. The clusters do not resemble hornblende pseudomorphs, there is no evidence of a microcrystalline rim around the outside of the cluster, and they lack the presence of the black microcrystalline material found in all other hornblende breakdown products. Based on these things, I interpret that these clusters are not hornblende breakdown reaction products. It is likely that they are 
accumulations of phenocrysts from the magma chamber walls, from the cumulate pile, or phenocryst agglomerates.

\subsection{Changes in Magma Chamber Conditions Recorded in Plagioclase}

Plagioclase records fluctuations in magma chamber conditions throughout the growth cycle of the crystal. The coupled substitution of $\mathrm{Ca}-\mathrm{Al}$ and $\mathrm{Si}-\mathrm{Na}$ in the crystal structure "freezes" the chemistry of each growth zone prohibiting diffusion across zones (Grove et al., 1984). Plagioclase zoning, or changes in An mol\% of the crystal, from core to rim can indicate the magmatic processes inside the volcano at the time of formation of that particular zone. Many of these magmatic processes can not be distinguished from one another by textural or major element chemical analysis alone, such as increased temperature versus increased $\mathrm{H}_{2} \mathrm{O}$ content. The use of trace elements variations in addition to An mol\% variations can help to distinguish between these (Singer et al., 1995 and Ginibre et al., 2002b). Changes which can be recorded in plagioclase zoning include: 1) magma mixing resulting in compositional change within the magma chamber, 2) magmatic temperature change, 3) change in amount of dissolved $\mathrm{H}_{2} \mathrm{O}$, 4) changes resulting from convection-driven magma chamber circulation, 5) pressure changes, and 6) small-scale equilibrium crystallization kinetics (Singer and Pearce, 1993; Singer et al., 1995; Holten et al., 1997).

\section{3a Magma Mixing}

Magma mixing changes the composition of the magma, and mixes together crystals which were in equilibrium with each magma. The compositional change of the magma will affect the An mol\% of new plagioclase zones crystallizing in equilibrium with the magma. Calcic plagioclase (i.e. high An) crystallizes in equilibrium with mafic 
(calcic) magma, and becomes more sodic as the magma is driven toward a more felsic composition. Mixing events can be recorded as variations in An mol\%. Mixing with a more mafic magma will cause a increase in the calcium content of the magma, and subsequently the lower An mol\% growth zone in contact with the magma will no longer be in equilibrium and resorption will take place. Plagioclase crystallization will continue at a higher An mol\%. Textural and chemical analysis of this plagioclase will show resorption surfaces cutting across one or many zones and An mol\% spikes where mixing with a more mafic magma was recorded. Mixing with a more felsic magma will result in outward crystallization of more sodic plagioclase, and therefore transects of the grains will show sudden drops in An mol\%. Fluctuations in trace element concentrations in plagioclase will also be expected with magma mixing. Mixing with a more mafic magma will bring higher concentrations of $\mathrm{Fe}, \mathrm{Mg}$, and $\mathrm{Ti}$. Crystal structure constraints cause these elements to have a negative correlation with An mol\%, therefore mixing with a more mafic magma and partitioning have opposing effects. Mixing with a more felsic magma is likely to cause an increase in the concentration of $\mathrm{Sr}$ in the plagioclase because Sr partitioning into plagioclase is enhanced by the $\mathrm{Na}$ content of the plagioclase. The decrease in the An mol\% of the plagioclase in equilibrium with a more felsic magma will increase the partitioning of Sr into the crystal structure.

Plagioclase transects from Calbuco show An mol\% spikes as well as occasional An mol\% drops. In thin section, these An spikes can be texturally correlated with resorption surfaces which cut across one or more compositional zone. In plagioclase in the andesite, Fe typically, but not always, increases with $\mathrm{An}$ mol\% spikes while $\mathrm{Mg}$ decreases (Figure 78, chapter 6); Ti typically has no correlation (Figure 78, chapter 6). In 
basaltic andesite, Fe has no apparent correlation with $\mathrm{An}$ mol\% spikes while $\mathrm{Mg}$ tends to increase and Ti typically decreases. Fe, $\mathrm{Mg}$, and $\mathrm{Ti}$ are used as indicators of mafic input, however their inconsistent correlations may indicate that data quality for $\mathrm{Mg}$ and $\mathrm{Ti}$ are poor (see chapter 6); or 1) that mafic magma is not being incorporated into the magma chamber and that An mol\% spikes and resorption zones are indicative of another process, 2) that concentrations of these elements in the original magma and/or the newly introduced magma are low, or 3) that the concentrations of these elements in the plagioclase is low due to the high An mol\% of the plagioclase and the negative correlation of these elements with An content. Basalt and basaltic andesite from Osorno, the possible parent composition for Calbuco (Lopez-Escobar et al., 1995) have similar amounts of $\mathrm{Fe}, \mathrm{Mg}$, and $\mathrm{Ti}$ (as well as $\mathrm{Sr}$ ), to Calbuco basaltic andesite and andesite. This uniformity in the composition of mafic endmembers indicates that the inconsistencies in correlation with An mol\% spikes are not likely caused by differences in the concentrations of these elements between two mixing magmas. Taken alone, the correlation of $\mathrm{Fe}$ with $\mathrm{An} \mathrm{mol} \%$ spikes in the andesite is consistent with input of mafic magma (ex. section 7.3a above). Gradual drops happen over tens of microns (i.e., several analysis points) and abrupt drops are large decreases, ranging from approximately 12-24 An mol\%, within 10 microns. Gradual drops in An mol\% would be consistent with mixing with a more felsic, or differentiated magma as the two magmas will homogenize over time causing a gradual compositional change throughout the whole magma chamber.

\section{3b Temperature Changes}

Temperature plays a role in the composition of the plagioclase crystallized. Higher temperatures will stabilize more calcic plagioclase and the calcium content of the 
plagioclase will decrease as the temperature decreases (Figure 98a). Therefore, a change in the temperature of the magma chamber will result in a change in the An mol\% of the plagioclase crystallizing in equilibrium. Raising the magma temperature will increase the An mol\%. Conversely, decreasing the temperature will crystallize lower An plagioclase. Transects from the core to the rim of a plagioclase grain will show sudden drops in An content if the magmatic temperature has decreased and sudden increases, spikes, in An content with temperature increases. In addition to An spikes, increased temperature will also result in resorption of the outermost zone or zones of the plagioclase which were in equilibrium with the magma before the temperature increase. Temperature fluctuations alone do not have a strong effect on the partitioning of $\mathrm{Mg}$, $\mathrm{Ti}$, or $\mathrm{Sr}$ into plagioclase; however Fe may have a negative correlation with temperature (Ginibre et al., 2002b; Sugawara, 2001). Therefore, considering the effects of temperature variation alone, the $\mathrm{Ca}$ and $\mathrm{Na}$, and possibly $\mathrm{Fe}$, contents of the plagioclase will be observed to change. However, since temperature fluctuations are likely caused by mixing with magma of a different temperature, effects listed above will also be recorded. Transects of plagioclase from Calbuco show both An mol\% drops and spikes, as well as resorption surfaces. This is consistent with both a rise and drop in temperature, which would be expected as a result of periodic mixing between more and less mafic magmas.

\section{3c Dissolved $\mathrm{H}_{2} \mathrm{O}$ Content}

Dissolved $\mathrm{H}_{2} \mathrm{O}$ in the magma also has an effect on the composition of the plagioclase crystallized in equilibrium. An $\mathrm{H}_{2} \mathrm{O}$ rich magma will stabilize calcic plagioclase. Due to the depression of the plagioclase solidus with water saturation (Figure 98b), initial plagioclase crystallization will be suppressed until lower 
temperatures are reached, and therefore higher An plagioclase will be stable at lower temperatures than plagioclase with the same An content in an anhydrous magma. Variations in dissolved water content will be recorded in variations in the An mol\% of the growth zone in equilibrium with magma. A decrease in $\mathrm{H}_{2} \mathrm{O}$ in the magma will cause a decrease in the An mol\% which is in equilibrium.

One likely method for water entering the evolving Calbuco magma is through crustal contamination with hydrous country rocks. López-Escobar et al., 1995 noted that basement rocks consist of several units which could contribute to the water content of the magma during crustal assimilation. One of the metamorphic host rocks for the underlying Miocene Patagonian Batholith is a staurolite-bearing mica schist of the Sotomó Chaiquenes Metamorphic Complex. In addition, the plutons making up the batholith also have hydrous assemblages containing hornblende, and other amphibole varieties, and biotite with minor amounts of muscovite. Based on major, trace element, and isotopic evidence, López-Escobar et al. (1995) and Hickey-Vargas et al. (1995) concluded that a pelitic metamorphic rock, not represented among the xenoliths, was the dominant contaminant for Calbuco lavas. In either of these cases, increased $\mathrm{H}_{2} \mathrm{O}$ contents would be associated with a felsic crustal input. Transects from core to rim of plagioclase grains will show an An spike and resorption if the $\mathrm{H}_{2} \mathrm{O}$ in the magma increases, and a drop in $\mathrm{An} \mathrm{mol} \%$ if $\mathrm{H}_{2} \mathrm{O}$ content decreases. The partitioning of $\mathrm{Fe}, \mathrm{Mg}$, $\mathrm{Ti}$, and $\mathrm{Sr}$ between plagioclase and melt is not directly affected by the $\mathrm{H}_{2} \mathrm{O}$ content of the magma; therefore, fluctuations in these trace elements in correlation with An mol\% fluctuations would not be expected except when related to other changes induced by contamination. 
As discussed above, transects of plagioclase from Calbuco show both An mol\% spikes and drops, and also resorption surfaces. In the andesite, spikes are accompanied by Fe-enrichment, which is inconsistent with felsic input, but could result from increased $\mathrm{Fe}^{3+} / \mathrm{Fe}^{2+}$. In the basaltic andesite, there is no $\mathrm{Fe}$ enrichment, thus increased $\mathrm{H}_{2} \mathrm{O}$ is a possible cause for An mol\% spikes.

Ca\# plots (Figure 99) of bulk rock versus plagioclase phenocryst and megacryst cores and rims relative to experimentally derived exchange partition coefficients $(\mathrm{Kd})$ for $\mathrm{Na}$ and $\mathrm{Ca}$ (Sisson and Grove, 1993a) show that initial crystallization took place in a water rich environment. The exchange $\mathrm{Kd}$ values for $\mathrm{Ca}-\mathrm{Na}$ in plagioclase and melt were derived from water saturated experiments containing 2,4 , and $6 \mathrm{wt} \% \mathrm{H}_{2} \mathrm{O}$ at $2-5,1$, and 2 kbars pressure respectively (Sisson and Grove, 1993a). These Kd values bracket the majority of the core compositions of the phenocrysts and megacrysts suggesting that these cores crystallized in the presence of high $\mathrm{H}_{2} \mathrm{O}$ contents or at $\mathrm{H}_{2} \mathrm{O}$ saturation. The rims of both crystal populations are not as well constrained by the $\mathrm{Kd}$ values. Approximately half of the rims on the phenocryst grains are bracketed by these values, whereas the other half of the phenocryst rims and none of the megacrysts rims are bracketed. Kd values for anhydrous crystallization of plagioclase at atmospheric pressure are also plotted against the rim Ca\# values and successfully bracket some of the rim values for both the phenocrysts and megacrysts. This would suggest that the rims crystallized in the presence of either a lower concentration of dissolved water, or a pressure lower than that represented by the Kd values for the given water contents. In order for the water concentration in the magma to change and affect the plagioclase rim crystallization, one or more of three processes needs to take place. 1) Calbuco would 
need to have undergone degassing to release some of the dissolved water, 2) a decline in the rate or amount of contamination of the magma chamber with hydrous country rocks, and 3) small recharge events with less hydrous magma, both of which would also change the temperature and magma composition.

\section{3d Magma Convection}

Convection driven circulation can be difficult to distinguish from episodic changes in composition, temperature, $\mathrm{H}_{2} \mathrm{O} w t \%$, and pressure. Convection in a magma chamber can take crystals through compositional, temperature, $\mathrm{H}_{2} \mathrm{O}$ wt $\%$, and pressure gradients within the magma chamber (Ginibre et al., 2002b). As the crystal passes through these gradients, the An mol\% is affected in the same way it would be for magma mixing, temperature change, fluctuations in $\mathrm{H}_{2} \mathrm{O}$ content, and changes in pressure. Ginibre et al. (2002b) distinguished convection in the magma chamber from temperature changes due to episodic mixing or differentiation by a lack of correlation of resorption between individual crystals. They concluded that when resorption surfaces are not present in all crystals, there has been convective crystal movement through thermal and compositional gradients, rather than discrete events which affect all crystals. Couch et al. (2001) cited the presence of crystals which display a range of disequilibrium features, such as reversely and normally zoned crystals, resorption surfaces, wide ranges of mineral compositions and minerals not in equilibrium with the surrounding rock matrix as evidence for magma chamber convection through thermal, but not compositional, gradients. In their study, they found crystals displaying all of these disequilibrium features on the scale of a single thin section. In agreement with Couch et al. (2001), a single thin section from Calbuco can contain plagioclase which is normally and reversely 
zoned, sieve textured, and has resorption surfaces within zoning. Similar to the findings of Ginibre et al. (2002b), there is no major element correlation of resorption surfaces between crystals. There is also no correlation between $\mathrm{Fe}, \mathrm{Mg}, \mathrm{Ti}$, or $\mathrm{Sr}$ incorporation into the crystal in connection with resorption surfaces, which would be expected as the result of convection mainly through a compositional gradient. The lack of correlation and presence of a variety of disequilibrium features provides evidence in support of convection through temperature and $\mathrm{H}_{2} \mathrm{O}$ wt $\%$ gradients recorded in plagioclase crystals.

\section{3e Pressure Changes}

Pressure variations in the magma chamber have only a small effect on the composition of plagioclase compared to temperature or water content. According to Ginibre et al. (2002b), there is a variation of $20 \mathrm{~mol} \%$ An in the plagioclase for every 12 kbar of pressure. Therefore, convection through a pressure gradient is not likely to be recorded in plagioclase zoning. Two processes which would cause a large and rapid drop in pressure are degassing and eruption. Degassing releases dissolved volatiles from the magma which lowers the volatile content in the magma. Water, although not the only volatile dissolved in magma, is commonly released during degassing, which would lower the $\mathrm{H}_{2} \mathrm{O}$ content of the magma and therefore cause less calcic plagioclase to begin to crystallize. This type of rapid decompression could be recognized in a transect of a zoned plagioclase by a sudden drop in An content, and may also cause sieve textures to develop in plagioclase (Singer et al., 1995; Hammer and Rutherford, 2002; Couch et al., 2003b). During eruption, plagioclase growth is rapid which causes zones of progressively more sodic plagioclase to crystallize (Singer et al., 1995; Hammer and Rutherford, 2002; Couch et al., 2003b). Eruption events will be seen in plagioclase 
transects as sudden drops in An mol\% at the rim of crystal. Eruption events prior to the final eruption in the life of a crystal may also be recorded throughout the growth history of the crystal due to the fact that not every volcanic eruption will completely empty the magma chamber. $\mathrm{Fe}, \mathrm{Mg}, \mathrm{Ti}$, and $\mathrm{Sr}$ are not affected by variations in pressure. Rare plagioclase with sieve textures are found in Calbuco, and sharp drops in An $\mathrm{mol} \%$ can be found at the rim of one-third of all the analyzed grains as well as in the interior of a few. Crystals with sudden An mol\% drops at the rim are recording the eruption which brought them to the surface, while sudden drops in the interior of the crystal are likely recording prior eruption events. Sieve textured crystals may be recording degassing events, but their low modal abundance may also indicate that the core of the crystal was out of equilibrium with the magma and possibly a xenocryst. Since $\mathrm{Fe}, \mathrm{Mg}, \mathrm{Ti}$, and $\mathrm{Sr}$ are not affected by pressure, correlation between these elements and An mol\% variations would not be expected as a result of pressure changes.

\section{3f Equilibrium Crystallization Kinetics}

During plagioclase crystallization, coupled substitution of CaAl and NaSi determine the An mol\% of the crystal. As plagioclase crystallizes in equilibrium, the magma immediately surrounding the crystal can gradually become depleted in $\mathrm{Ca}$ and $\mathrm{Al}$, thus it begins to incorporate increased amounts of $\mathrm{Na}$ and $\mathrm{Si}$, which in turn gradually enriches the surrounding magma in $\mathrm{Ca}$ and $\mathrm{Al}$. This exchange will result in zoning with low An mol\% variations commonly called oscillatory zoning. In a plagioclase transect from core to rim, these variations can be seen as shifts of up to 2 mol\% An. All of the studied trace elements, $\mathrm{Fe}, \mathrm{Mg}$, $\mathrm{Ti}$, and $\mathrm{Sr}$, have a negative correlation with the $\mathrm{An} \mathrm{mol \%}$ of the plagioclase, however An variations of this magnitude would not correlate with 
significant shifts in their concentration in plagioclase. Fine scale zoning oscillations of 1 2 An $\mathrm{mol} \%$ are seen in plagioclase transects but are overprinted with larger An mol\% fluctuations. This could be indicative of crystals which have seen periods of equilibrium crystallization which were interrupted by one or more of the processes discussed above.

\subsection{Overview of Magmatic Properties-Calbuco Andesite and Basaltic Andesite}

\section{4a Phenocryst Stability-Calbuco Andesite}

Phenocrysts of plagioclase, orthopyroxene, magnetite, and rare hornblende, clinopyroxene and olivine are found in the andesitic eruptive products from Calbuco. Bulk analyses of the andesite plot on the hydrous 2 kbar cotectics of the Cpx-Ol-Qtz and Plag-Cpx-Qtz phase diagrams (Figure 100, Figure 101), indicating that a mineral assemblage of plagioclase, olivine, and clinopyroxene should be stable in the andesite. Despite this, orthopyroxene and plagioclase are the most abundant mineral phases found in the andesite with only rare clinopyroxene and olivine crystals. The olivine, and some of the clinopyroxene, found are in reaction and decomposing and are therefore texturally out of equilibrium with the andesite. Based on partition coefficients for the exchange of Fe-Mg between the crystals and the magma, Figure 102 and Figure 103 show that some crystals of olivine, orthopyroxene, and clinopyroxene are chemically stable in Calbuco andesite. The remaining clinopyroxene and orthopyroxene grains trend to higher concentrations of $\mathrm{Fe}$ than that which would be in equilibrium with the andesite, as well as some of the olivine crystals. A few olivine crystals also trend toward higher $\mathrm{Mg}$ concentrations. The pigeonite rims are much higher in Fe and not stable in the andesite. The finding that not all of the pyroxene and olivine crystals are in equilibrium with the andesite is expected with the occurrence of magma chamber convection. Couch et al. 
(2001) determined that one result of magma chamber convection is the presence of a diverse group of mineral phases which were not in equilibrium with the surrounding rock matrix. Plagioclase phenocrysts show some disequilibrium textures. The cores, however, are stable in Calbuco andesite. Exchange $\mathrm{Kd}$ values for $\mathrm{Ca}-\mathrm{Na}$ under hydrous conditions, ranging from 1-2 kbars (Figure 99), bracket the phenocryst core compositions and show that plagioclase rim compositions range from being stable under the same conditions as the cores to less hydrous, lower pressure conditions. Plagioclase megacryst cores in the andesite plot at the upper limit of the exchange Kd plots and trend to possibly higher water contents than that experimentally produced by Sisson and Grove (1993a), however the rims of these crystals are in the same stability range as the phenocryst rims. The megacrysts have unzoned anorthitic cores with zoned rims of lower An content. The cores of the crystals are fractured and the core and rim are separated by a significant drop in An mol\%. The unzoned nature of the cores and the large An mol\% decrease at the beginning of the zoned rims shows that these crystals are texturally out of equilibrium with the andesite. Chemically however, plagioclase megacryst and phenocryst cores, and approximately half of the rims, are stable in the andesite from Calbuco. Hornblende and olivine crystals show textural evidence of instability and reaction. The factors controlling the stability of hornblende are the pressure of the magma chamber, the dissolved water content of the magma, magma chemistry, and, to a lesser degree, magmatic temperature. Hornblende phenocrysts are rounded and rimmed or completely replaced with opacite formed by the loss of $\mathrm{H}_{2} \mathrm{O}$ and increase of oxygen in the magma. Although these crystals are breaking down, partition coefficients for the exchange of $\mathrm{Al}-\mathrm{Si}$ and $\mathrm{Fe}-\mathrm{Mg}$ between the hornblende and the magma show that the hornblende is in chemical equilibrium with 
the magma (Figure 96, Figure 97). Therefore, hornblende is not stable under the physical conditions of the main body of the magma chamber but is still crystallizing from the magma. This indicates that the deeper portion of the magma chamber is at a high enough pressure and has enough dissolved $\mathrm{H}_{2} \mathrm{O}$ to stabilize hornblende. Due to the convection and recharge of the magma chamber, it is difficult to determine which mineral phases are stable. Chemically, hornblende, some olivine, orthopyroxene, and clinopyroxene, plagioclase cores, and approximately half of the plagioclase rims stable in the andesite from Calbuco, while some orthopyroxene, clinopyroxene, and olivine, and pigeonite rims are not chemically stable. Texturally, hornblende, olivine, and clinopyroxene, and select plagioclase zones are not stable in the andesite. Olivine, clinopyroxene, and hornblende are found only as rare phenocrysts. Hornblende is breaking down and olivine is reacting with the magma, and some of the clinopyroxene phenocrysts are sieve textured. Plagioclase shows complex oscillatory zoning and resorption surfaces. The andesite is likely to be crystallizing plagioclase, orthopyroxene, hornblende, and magnetite with small amounts of olivine and clinopyroxene. Although the hornblende is rare, it is in chemical equilibrium with the magma and is found in more abundantly in the cumulate gabbroic xenoliths (discussed below). Partition coefficients to determine the chemical stability of magnetite in the andesite have not been found, however they are a common mineral phase in arc magmas and there is no textural evidence of instability, therefore they are likely to be stable in the andesite. The majority of the olivine and clinopyroxene are likely to have crystallized before the magma was differentiated to the point of andesite. 


\section{4b Phenocryst Stability-Calbuco Basaltic Andesite}

Phenocrysts of plagioclase, olivine, and orthopyroxene are found in basaltic andesite eruptive products from Calbuco along with microphenocrysts and rims of pigeonite (on olivine phenocrysts). In contrast to andesite, hornblende does not occur as a crystallizing phase. Bulk analysis of the basaltic andesite plotted on Cpx-Ol-Qtz and Plag-Cpx-Qtz phase diagrams (Figure 100, Figure 101) indicate that the stable mineral phases expected are plagioclase and olivine. Despite this, orthopyroxene is also an abundant mineral phase in the basaltic andesite. Compared with andesite plotted on the same Cpx-Ol-Qtz and Plag-Cpx-Qtz phase diagrams, basaltic andesite plots above the 2 kbar saturated cotectics, towards higher water pressures than andesite. Olivine crystals found rimmed with pigeonite and are therefore texturally out of equilibrium with the basaltic andesite. Based on partition coefficients for the exchange of Fe-Mg between the crystals and the magma, Figure 102 and Figure 103 show that pigeonite and the majority of the olivine phenocrysts are chemically unstable in Calbuco basaltic andesite. Some orthopyroxene crystals are stable in the basaltic andesite, however increasing Fe content of the olivine causes it to trend away from the stability line ( $\mathrm{Kd}$ value). This trend of a few olivine and pyroxene crystals stable while the majority trend away from stability is similar to the chemical stability of pyroxene and olivine in Calbuco andesite. Due to magma recharge and subsequent magma chamber convection, mixing of andesite and basaltic andesite, the presence of several mineral phases out of equilibrium with the magma is not unexpected (Couch et al., 2001). Exchange $\mathrm{Kd}$ values for $\mathrm{Ca}-\mathrm{Na}$ in plagioclase under hydrous conditions, ranging from 1-2 kbars (Figure 99), bracket the phenocryst core compositions and show that plagioclase rim compositions range from 
being stable under the same conditions as the cores to less hydrous, lower pressure conditions. Plagioclase megacryst cores in the basaltic andesite plot at the upper limit of the exchange $\mathrm{Kd}$ plots and trend to possibly higher water contents than that experimentally produced by Sisson and Grove (1993a), however the rims of these crystals are in the same stability range as the phenocryst rims. The megacrysts have unzoned anorthitic cores with zoned rims of lower An content. The cores of the crystals are fractured and the core and rim are separated by a significant drop in An mol\%. The unzoned nature of the cores and the large An mol\% decrease at the beginning of the zoned rims shows that these crystals are texturally out of equilibrium with the basaltic andesite. Chemically however, plagioclase megacryst and phenocryst cores, and approximately half of the rims, are stable in the basaltic andesite from Calbuco, while only the most Mg-rich orthopyroxene and olivine are chemically stable. Texturally, olivine is also unstable in the basaltic andesite. Therefore, the basaltic andesite was probably crystallizing plagioclase + orthopyroxene + magnetite + olivine.

\section{4c Magmatic Physical Properties-Calbuco Andesite}

Physical properties of the andesitic magma from Calbuco have been estimated from published density, geothermometry, and geobarometry calculations and experimentally derived phase diagrams for andesite and basaltic andesite from Medicine Lake, Volcán Colima, Soufrière Hills, and Mount Pelée. Temperature estimates using geothermometry calculations were attempted using two-pyroxene thermometry from Lindsley (1983) on clinopyroxene and orthopyroxene phenocrysts with the same range of Mg-numbers and plagioclase-hornblende thermometry from Holland and Blundy (1994).

The two pyroxene thermometry gave a very broad temperature range due to crystal 
compositions clustering over several isotherms on the thermometer quadrilateral, therefore temperature values from this procedure are not reported. Pressure estimates using geobarometry calculations have been done for the analyzed hornblende phenocryst following the regression in Hammarstrom and Zen (1986) for measurements of $\mathrm{Al}$ in hornblende. Density calculations were done using a CIPW norm calculation spreadsheet provided by Kurt Hollocher (http://www.union.edu/PUBLIC/GEODEPT/COURSES/ petrology/norms.htm).

7.4c.i Magmatic Temperature-Calbuco Andesite

Plagioclase-hornblende thermometry calculations give a temperature range for hornblende in the andesite of $840-930^{\circ} \mathrm{C}$. Published phase diagrams (Figure 61, chapter 5) show temperature ranges of possible andesite stability, based on the mineral assemblage, of approximately $810-975^{\circ} \mathrm{C}$. Despite the lack of quartz in the crystallizing assemblage of Calbuco andesite (discussed in chapter 5), the temperature ranges calculated from the $\mathrm{Al}$ in hornblende geothermometry overlap with the ranges from the phase diagrams.

7.4c.ii Magmatic Pressure-Calbuco Andesite

Partition coefficient plots (Figure 99) for the exchange of $\mathrm{Ca}-\mathrm{Na}$ between plagioclase phenocrysts and melt show that the cores of these crystals are stable between approximately 1-2 kbars (3-6 km) under water saturated conditions or 2-5 kbars (6-15 $\mathrm{km})$ with undersaturated conditions, and the majority of the rims from 2-5 kbar (6-15 km) under water undersaturated conditions to atmospheric pressure $(0 \mathrm{~km})$. These same $\mathrm{Kd}$ plots show that plagioclase megacryst cores are stable at $2+$ kbars $(6+\mathrm{km})$ under water saturated conditions and rims are stable under the same pressure conditions as the 
phenocryst rims. Calculated phase diagrams (Figure 100, Figure 101) show that Calbuco andesite could be stable at 2 kbars pressure under either water saturated or unsaturated conditions. Published phase diagrams in Figure 61 (chapter 5) also show that Calbuco andesite could be stable at approximately $1.25-2.25$ kbars pressure, which corresponds to approximately $4-7 \mathrm{~km}$, or at a higher pressure of $4 \mathrm{kbars}(12 \mathrm{~km})$. The only geobarometry method which gives pressure values which do not coincide with other values is the $\mathrm{Al}$ in hornblende regression. The pressure range calculated by this method is 6-8 $\pm 2 \mathrm{kbars}(18-24 \pm 6 \mathrm{~km})$, however this method is expected to return pressure values which are higher than actual values due to the lack of quartz in the crystallizing assemblage (discussed in chapter 5).

7.4c.iii Dissolved Water Content and Magma Density-Calbuco Andesite

Dissolved water is common in arc magmas. Initially, water enters the mantle from dehydration of the subducting slab (Stern, 2002), so Calbuco's initial magma derived from the mantle would be hydrous. In the SVZ, Sellés (2004) suggested that excess water may also be coming from a subducted fracture zone which lies underneath Calbuco, and also Nevado de Longavi, a hornblende-bearing volcano in the TSVZ. The fracture zones expose large amounts of the hydrous mineral serpentinite deep within the subducted lithosphere. For Calbuco, crustal contamination with hydrous country rock probably has also contributed to the water in the andesite (López-Escobar et al., 1995). Dissolved water content for andesite stability extrapolated from published phase diagrams in Figure 61 (chapter 5) is approximately 4.5-6 wt \%. Calculated phase diagrams (Figure 100, Figure 101) show an overlapping dissolved water content range of up to $6 \mathrm{wt} \% \mathrm{H}_{2} \mathrm{O}$. In agreement with this, the dissolved water content range for the 
stability of the plagioclase cores on the $\mathrm{Ca}-\mathrm{Na}$ exchange $\mathrm{Kd}$ plots (Figure 99) is approximately $4-6 \mathrm{wt} \% \mathrm{H}_{2} \mathrm{O}$, and for the plagioclase rims the range is $2-4 \mathrm{wt} \%$. Cores of the plagioclase megacrysts fall into a higher dissolved water content range on the $\mathrm{Ca}-\mathrm{Na}$ exchange $\mathrm{Kd}$ plots of $6+\mathrm{wt} \% \mathrm{H}_{2} \mathrm{O}$, however the rims of these crystals are in the same approximate range as the phenocryst rims $(2-4 \mathrm{wt} \%)$. The average calculated density for the andesite erupted from Calbuco is $2.58 \mathrm{~g} / \mathrm{cm}^{3}$. There is a slight difference in the average andesitic densities of each stratigraphic unit; Calbuco 1 is $2.56 \mathrm{~g} / \mathrm{cm}^{3}$, Calbuco 2 is $2.57 \mathrm{~g} / \mathrm{cm}^{3}$, Calbuco 3 is $2.58 \mathrm{~g} / \mathrm{cm}^{3}$, and Calbuco 4 is $2.59 \mathrm{~g} / \mathrm{cm}^{3}$. This compares with densities of 2.6-2.76 g/cm3 for plagioclase (albite-anorthite respectively) and 3.19-3.56 $\mathrm{g} / \mathrm{cm}^{3}$ for clinopyroxene, $3.21-3.96 \mathrm{~g} / \mathrm{cm}^{3}$ for orthopyroxene, $3.20-3.59 \mathrm{~g} / \mathrm{cm}^{3}$ for hornblende, $3.22-4.39 \mathrm{~g} / \mathrm{cm}^{3}$ for olivine, and $5.18 \mathrm{~g} / \mathrm{cm}^{3}$ for magnetite (Nesse, 2000).

\section{4d Magmatic Physical Properties-Calbuco Basaltic Andesite}

Physical properties of the basaltic andesitic magma from Calbuco have been estimated in a similar manner as those of andesite, using published density calculations and experimentally derived phase diagrams for andesite and basaltic andesite from Medicine Lake, Volcán Colima, Soufrière Hills, and Mount Pelée. Density calculations were done using a CIPW norm calculation spreadsheet provided by Kurt Hollocher (http://www.union.edu/PUBLIC/GEODEPT/COURSES/petrology/norms.htm).

\section{3d.i Magmatic Pressure-Calbuco Basaltic Andesite}

Partition coefficient plots (Figure 99) for the exchange of $\mathrm{Ca}-\mathrm{Na}$ between plagioclase phenocrysts and melt show that the cores of these crystals are stable between approximately 1-2 kbars (3-6 km) under water saturated conditions or 2-5 kbars (6-15 $\mathrm{km})$ with undersaturated conditions and the majority of the rims from $2-5 \mathrm{kbar}(6-15 \mathrm{~km})$ 
under water undersaturated conditions to atmospheric pressure $(0 \mathrm{~km})$. These same $\mathrm{Kd}$ plots show that plagioclase megacryst cores are stable at $2+$ kbars $(6+\mathrm{km})$ under water saturated conditions and rims are stable under the same pressure conditions as the phenocryst rims. These pressure conditions are overlapping the pressures for phenocryst cores and rims and megacryst cores and rims of plagioclase crystals in Calbuco andesite. Calculated phase diagrams (Figure 100, Figure 101) show that Calbuco basaltic andesite could be stable at greater than 2 kbars pressure under either water saturated or unsaturated conditions. Published phase diagrams in Figure 61 (chapter 5) also show that the basaltic andesite could be stable at approximately $1.25-2.5$ kbars pressure, which corresponds to approximately $4-8 \mathrm{~km}$, or at a higher pressure of $4 \mathrm{kbars}(12 \mathrm{~km})$.

7.4d.ii Temperature, Dissolved Water Content, and Density-Calbuco Basaltic Andesite Published phase diagrams (Figure 61, chapter 5) show temperature ranges of possible basaltic andesite stability, based on the mineral assemblage, of approximately $850-900^{\circ} \mathrm{C}$ and broadly from $975-1130^{\circ} \mathrm{C}$ for pressure ranges of $1.25-2.5 \mathrm{kbars}$, and from $930^{\circ} \mathrm{C}$ upwards at 4 kbars. The basaltic andesite is also an inherently hydrous magma due to dehydration of the subducting slab. The fracture zone, discussed above, which was proposed to be subducting beneath Calbuco could be an additional source of water in the basaltic andesite. It has been determined that Calbuco andesite is contaminated with hydrous country rock (López-Escobar et al., 1995), and it is possible that the basaltic andesite is also contaminated with the same hydrous country rock. Isotopic studies would need to be conducted to determine this. Dissolved water content for basaltic andesite stability extrapolated from the published phase diagrams is approximately 2-6.25 wt \%. Calculated phase diagrams (Figure 102, Figure 103) show a probable dissolved 
water content of greater than $6 \mathrm{wt} \% \mathrm{H}_{2} \mathrm{O}$. The dissolved water content range for the stability of the plagioclase cores on the $\mathrm{Ca}-\mathrm{Na}$ exchange $\mathrm{Kd}$ plots (Figure 99) is approximately $4-6 \mathrm{wt} \% \mathrm{H}_{2} \mathrm{O}$, and for the plagioclase rims the range is $2-4 \mathrm{wt} \%$. Cores of the plagioclase megacrysts fall into a higher dissolved water content range on the $\mathrm{Ca}-\mathrm{Na}$ exchange $\mathrm{Kd}$ plots of $6+\mathrm{wt} \% \mathrm{H}_{2} \mathrm{O}$, however the rims of these crystals are in the same approximate range as the phenocryst rims $(2-4 \mathrm{wt} \%)$. Kd plots of the cores of the plagioclase phenocrysts and megacrysts show a dissolved water content for basaltic andesite stability which is similar to water content extrapolated from the published and calculated phase diagrams. The average calculated density for the basaltic andesite erupted from Calbuco is $2.61 \mathrm{~g} / \mathrm{cm}^{3}$, from stratigraphic unit Calbuco 3 .

\section{4e Physical Properties of Entrained Gabbroic Xenoliths-Calbuco Andesite}

Gabbroic xenoliths entrained in the andesite have an overall mineral assemblage of plagioclase, hornblende, orthopyroxene \pm rare clinopyroxene, olivine, magnetite \pm rare ilmenite, and accessory apatite, phlogopite and Fe-sulfide minerals (pyrite or pyrrhotite). In sample 12-19-18, plagioclase, orthopyroxene, and magnetite are texturally stable while olivine is reacting to form orthopyroxene and magnetite. Hornblende poikilitically encloses all other grains and is only slightly broken down with small patches of opacite along cleavage planes. Only one clinopyroxene grain was found. In sample 12-20-3, the only phases which are texturally stable are magnetite and phlogopite. The xenolith has an overall granoblastic texture. Decomposition of plagioclase has left pockets of glass inside small rounded plagioclase grains which are also surrounded by interstitial glass. Hornblende has patches of opacite around the outside and throughout the crystal along cleavage planes. The hornblende, olivine, clinopyroxene, and orthopyroxene are mesh 
textured. Sample 12-20-8 has large grains of magnetite and plagioclase, which show no textural evidence of instability, with interstitial pockets of olivine, reacting to orthopyroxene and magnetite, and hornblende breaking down.

Overall, the maximum and minimum range of $\mathrm{Fe} / \mathrm{Mg}$ in olivine and pyroxene (orthopyroxene and clinopyroxene combined) from all three xenoliths, plotted against exchange Kd values (Figure 102, Figure 103), tend to bracket all of the clinopyroxene phenocryst values from the andesite, half of the orthopyroxene phenocryst values from the andesite and all of the orthopyroxene phenocryst values from the basaltic andesite, and only half of the olivine phenocryst values from both the andesite and basaltic andesite. The Fe/Mg overlap between all of the clinopyroxene phenocrysts and coarse clinopyroxene grains in gabbroic xenoliths indicates that these pyroxenes may have crystallized from magma of similar composition and conditions. The Fe/Mg correlation between orthopyroxene phenocrysts in the andesite and basaltic andesite with coarse orthopyroxene and olivine grains in gabbroic xenolith indicates that the phenocrysts may have crystallized in equilibrium with the coarse gabbroic grains at a magma composition which was less differentiated than andesite, possibly basaltic andesite. In contrast, the overall Ca-number range (Figure 99) from coarse grained plagioclase in all three gabbroic xenoliths falls equilibrium range and overlaps the compositions of the phenocryst and megacryst cores. This correlation with phenocryst and megacryst cores gives the same pressure and dissolved water content approximation for the coarse grained plagioclase of 1-2 kbars water saturated with 4-6 wt $\% \mathrm{H}_{2} \mathrm{O}$ and 2-5 kbars undersaturated at $2 \mathrm{wt} \% \mathrm{H}_{2} \mathrm{O}$. This corresponds to an approximate crystallization depth of 3-6 km and $6-15 \mathrm{~km}$ respectively. 


\section{4f Physical Properties of Entrained Crystal Clusters-Calbuco Andesite}

The overall mineral assemblage of the crystal clusters in Calbuco andesite consists of plagioclase, orthopyroxene, \pm clinopyroxene, \pm olivine, and magnetite. Olivine crystals, where present, are texturally unstable and reacting to from orthopyroxene and magnetite. Clinopyroxene crystals are rare in the clusters and sometimes sieve textured, and plagioclase, orthopyroxene, and magnetite do not show textural evidence of reaction. Based on this, it is likely that the stable phases in the crystal clusters are plagioclase, orthopyroxene, and magnetite.

\section{4g Physical Properties of Entrained Crystal Clusters-Basaltic Andesite}

The overall mineral assemblage of the crystal clusters in Calbuco basaltic andesite consists of plagioclase, orthopyroxene, and magnetite, \pm olivine. Olivine crystals, where present, are texturally unstable and reacting to from orthopyroxene and magnetite. Plagioclase, orthopyroxene, and magnetite do not show textural evidence of reaction. Based on this, it is likely that the stable phases in the crystal clusters are plagioclase, orthopyroxene, and magnetite.

\section{4h Volcanic Glass-Calbuco Andesite}

Volcanic glass is found trapped in plagioclase and pyroxene crystals and interstitially in gabbroic xenoliths and crystal clusters. In plagioclase phenocrysts, coarse grained plagioclase in gabbroic xenoliths, and plagioclase in crystal clusters the $\mathrm{SiO}_{2}$ $\mathrm{wt} \%$ of the glass ranges from dacitic to rhyolitic $\left(65-74 \mathrm{wt} \% \mathrm{SiO}_{2}, 65-70 \mathrm{wt} \% \mathrm{SiO}_{2}\right.$, and 63-74 wt $\% \mathrm{SiO}_{2}$ respectively) (Figure 104). In pyroxene phenocrysts and coarse grained pyroxene in gabbroic xenoliths the trapped volcanic glass ranges from dacitic to rhyolitic with $65-74 \mathrm{wt} \% \mathrm{SiO}_{2}$ and $69-70 \mathrm{wt} \% \mathrm{SiO}_{2}$ respectively. Interstitial glass in the crystal 
clusters and gabbroic xenoliths is similar to that trapped in plagioclase and pyroxene crystals. In general, $\mathrm{MgO}, \mathrm{Fe}_{2} \mathrm{O}_{3}$, and $\mathrm{CaO}$ are negatively correlated with $\mathrm{SiO}_{2}$ for all glass species while $\mathrm{Al}_{2} \mathrm{O}_{3}, \mathrm{Na}_{2} \mathrm{O}$, and $\mathrm{K}_{2} \mathrm{O}$ are positively correlated with $\mathrm{SiO}_{2}$ although the data points tend to be scattered rather than fitting tightly to a trend. $\mathrm{TiO}_{2}$ and $\mathrm{P}_{2} \mathrm{O}_{5}$ do not have either a positive or negative correlation with $\mathrm{SiO}_{2}$. These correlations between $\mathrm{SiO}_{2}$ and other oxides for volcanic glass are similar to the oxide correlations with $\mathrm{SiO}_{2}$ for the eruptive products from Calbuco and Osorno (Figure 105), although the eruptive products data show little or no scatter about the trend. The scatter observed by the glass data could be the result of post entrapment crystallization of the glass as rich as dacite (ranges), as shown by glass inclusions in phenocrysts.

\subsection{Overview of Magmatic Processes}

Based on a synthesis of results from sections 7.1-7.3, I propose the following overview of the magmatic system at Calbuco. The magmatic plumbing system beneath Calbuco Volcano is an open system with the uppermost andesitic magma chamber being fed by recharge with a high- $\mathrm{Al}_{2} \mathrm{O}_{3}$ low-MgO basaltic andesite. The presence of magma recharge suggests that there is another magma chamber or storage/crystallization zone where the basaltic andesite evolves, and since basaltic andesite is not typically thought to be derived directly from the mantle, it is likely that there is more than one other magma chamber. Figure 106 is a sketch of the possible zones of magmatic storage and evolution beneath Calbuco. The upper-crustal level magma chamber is generally andesitic but may differentiate to compositions as evolved as dacite between basaltic andesite recharge events. The mid-crustal level magma chamber is the source of the recharging basaltic andesite. Looking at the system from the bottom, basalt derived from the mantle would 
first fractionate olivine + clinopyroxene + plagioclase \pm magnetite to become high- $\mathrm{Al}_{2} \mathrm{O}_{3}$ low-MgO basalt. Subsequently, the high- $\mathrm{Al}_{2} \mathrm{O}_{3}$ low-MgO basalt would initially fractionate plagioclase + olivine + magnetite \pm clinopyroxene with clinopyroxene crystallization diminishing due to rising magma. This is followed by fractionation of orthopyroxene \pm clinopyroxene + plagioclase + olivine + magnetite to become high$\mathrm{Al}_{2} \mathrm{O}_{3}$ low-MgO basaltic andesite. Ascent of the magma from a lower-crustal level magma chamber to the mid-crustal level magma chamber at a shallower depth causes the magma to lose saturation with clinopyroxene (Figure 100). Since clinopyroxene is not found in the basaltic andesite, it is likely that all phenocrysts have been removed by settling or resorption. Bindeman and Bailey (1999) reported that unzoned anorthite megacrysts crystallize from slow cooling high- $\mathrm{Al}_{2} \mathrm{O}_{3}$ basalt, so their origin would be in the mid-crustal level magma chamber. The high- $\mathrm{Al}_{2} \mathrm{O}_{3}$ low- $\mathrm{MgO}$ basaltic andesite is periodically injected into the upper-crustal magma chamber where it fractionates plagioclase, orthopyroxene, magnetite, and hornblende \pm clinopyroxene and olivine to form andesite. Since there is no additional magma chamber for the andesite to feed into, the magma is likely to differentiate to andesite with higher $\mathrm{SiO}_{2}$ than that of the erupted andesite, and may even become as $\mathrm{SiO}_{2}$ rich as dacite (approximately $63-65 \mathrm{wt} \% \mathrm{SiO}_{2}$ ). Magmatic processes taking place in the andesitic magma chamber, in addition to magma recharge, are magma chamber convection, crystal fractionation, and crustal contamination with hydrous country rock.

\section{5a Crystal Fractionation in Andesitic Magma Chamber}

Minerals crystallizing from Calbuco andesite (plagioclase, orthopyroxene, hornblende, and magnetite) subsequently attach themselves to the walls of the magma 
chamber or settle out of the magma and collect in cumulate piles on the floor of the magma chamber. There has been a long standing question of whether plagioclase would sink or float in the magma (Cawthorn, 2002 and references therein). One of the main controls on the sinking or floating of plagioclase is the density of the magma. The average density of Calbuco andesite is $2.58 \mathrm{~g} / \mathrm{cm}^{3}$ and according to Nesse (2000), the density of plagioclase (anorthite) is 2.76. Therefore, it is possible for plagioclase crystallized from the andesite to sink and collect in the cumulate pile with the denser mafic minerals. This is cumulate pile has been disrupted prior to eruption and entrained in the andesite as the studied gabbroic cumulate xenoliths. The minerals crystallized may also attach to the chamber walls. Disruption and entrainment of this mineral collection is a possible origin for the crystal clusters due to their lack of hornblende. Hornblende is found as rare phenocrysts, all of which have opacite rims. These rims indicate that the hornblende is not physically stable in the magma, however phenocrysts have been shown to be in chemical equilibrium with the magma. Since they are crystallizing from Calbuco andesite, they must only be stable at the bottom of the andesitic magma chamber. This also explains the increased abundance of hornblende fractionating out of the magma and being incorporated into the cumulate xenoliths without the presence of opacite rims. The little opacite found in the coarse grained hornblende in these gabbroic cumulates is mostly along cracks or cleavage plains suggesting that it formed during eruption.

\section{5b Magma Chamber Convection in Andesitic Magma Chamber}

Magma chamber convection circulates crystals through temperature, compositional and dissolved water gradients within the andesitic magma. One process which would be responsible for sustaining magma convection is basaltic andesite 
recharge which would cause a variation in magma composition and temperature and possibly a variation in dissolved water content. According to Cawthorn (2002), vigorous convection is responsible for keeping phenocrysts in suspension in the magma rather than allowing them to settle into the cumulate pile. This process is particularly evident is oscillatory zoned plagioclase and can also be seen in the disequilibrium of minerals found in the andesite.

\section{5c Recharge of Andesitic Magma Chamber with Basaltic Andesite}

Due to the narrow $\mathrm{SiO}_{2}$ range of Calbuco over its lifetime, recharge is likely to happen through small, frequent basaltic andesite pulses. These frequent pulses would carry enough basaltic andesite to mix with the more silicic, possibly dacitic, magma in the upper-crustal magma chamber and form a hybrid andesite with approximately 55-60 wt $\% \mathrm{SiO}_{2}$, however they would also have to be small enough not to cause regular eruptions. Dacite has not been reported as an eruptive product of Calbuco. This could be because the dacite in the magma chamber is too crystal rich to erupt and must mix with basaltic andesite, causing resorption of some of the crystals, in order to enable eruption, or that the recharge with basaltic andesite, which would mix with dacite to form andesite, is at a steady enough rate to ensure that the overall composition of Calbuco remains andesitic. Another reason for the lack of reported dacitic compositions for Calbuco could be that a comprehensive study of pumice and other fallout deposits from Calbuco's eruptive events has yet to be done, future work in this area may uncover dacite erupted from Calbuco. Evidence for the mixing of the andesite and basaltic andesite after recharge can be found in the pigeonite rims and microphenocrysts in the basaltic andesite as well as the presence of plagioclase megacrysts. 


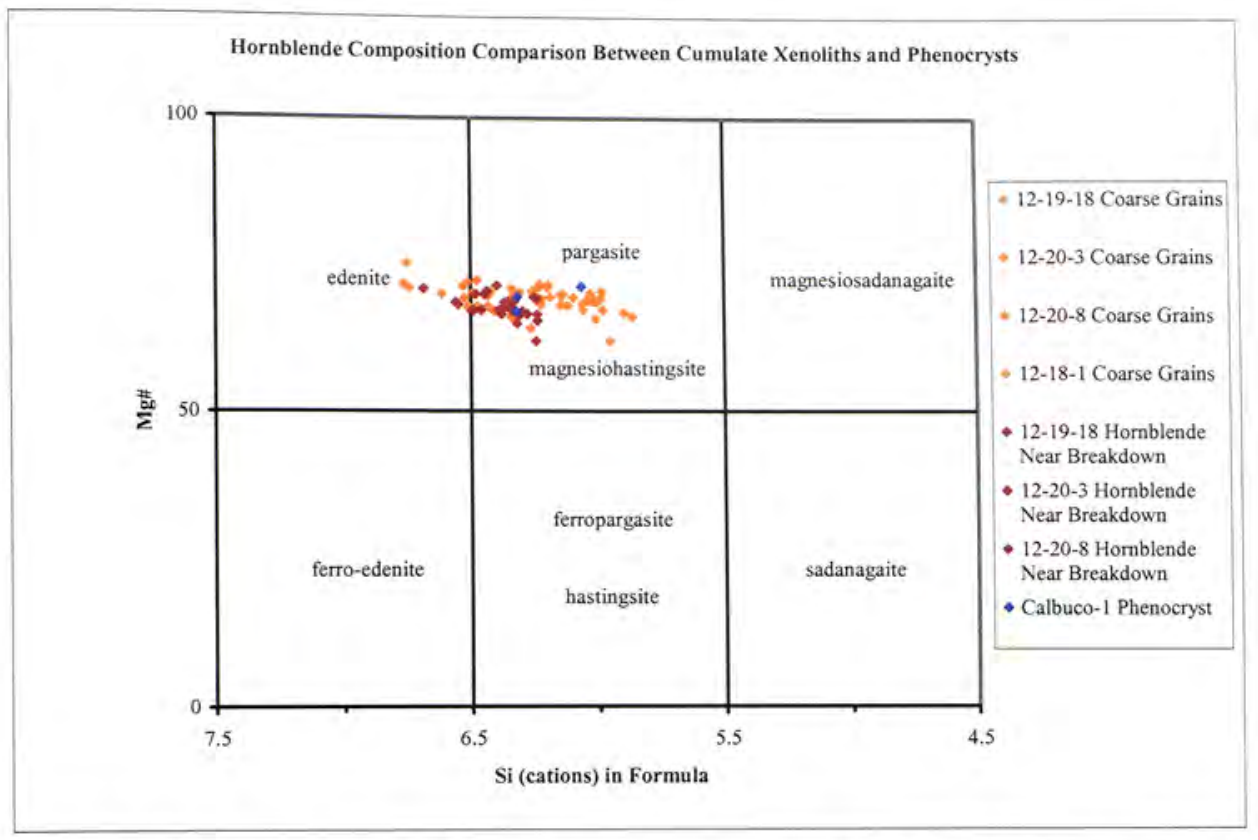

Figure 89: Composition of hornblende phenocrysts and from gabbroic xenoliths.

Plot of hornblende Mg-number versus $\mathrm{Si}$ cations in hornblende formula showing comparison of phenocryst and cumulate xenolith coarse grain compositions. Recalculation and plot after Leake et al. (1997)

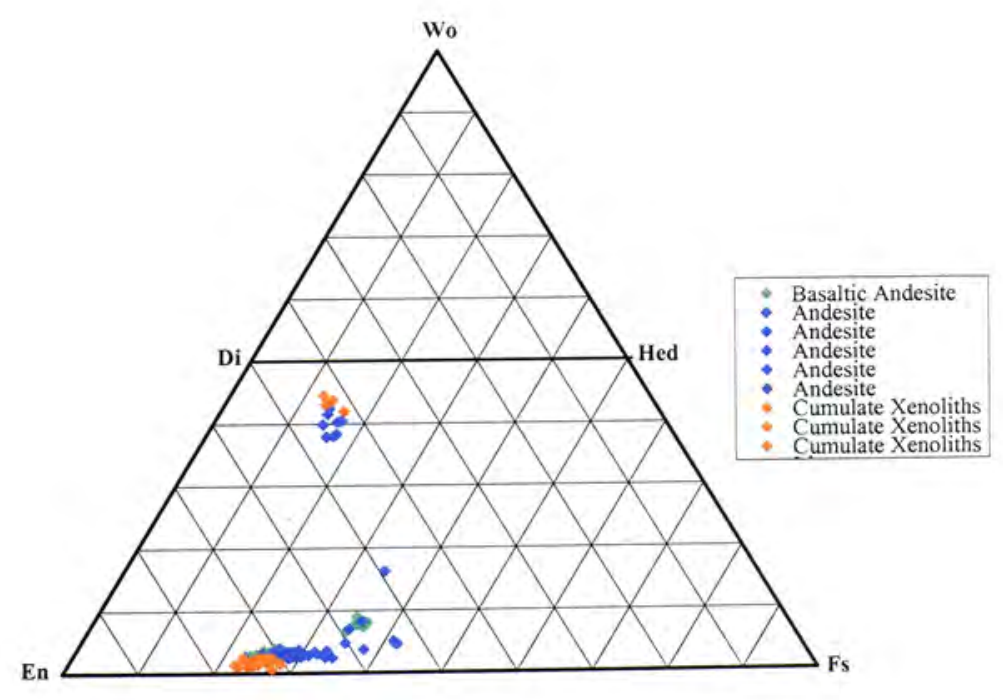

Figure 90: Composition of pyroxene phenocrysts and from gabbroic xenoliths. Ternary plot of pyroxene end member compositions comparing ortho- and clinopyroxene phenocrysts with cumulate xenolith coarse grains. 


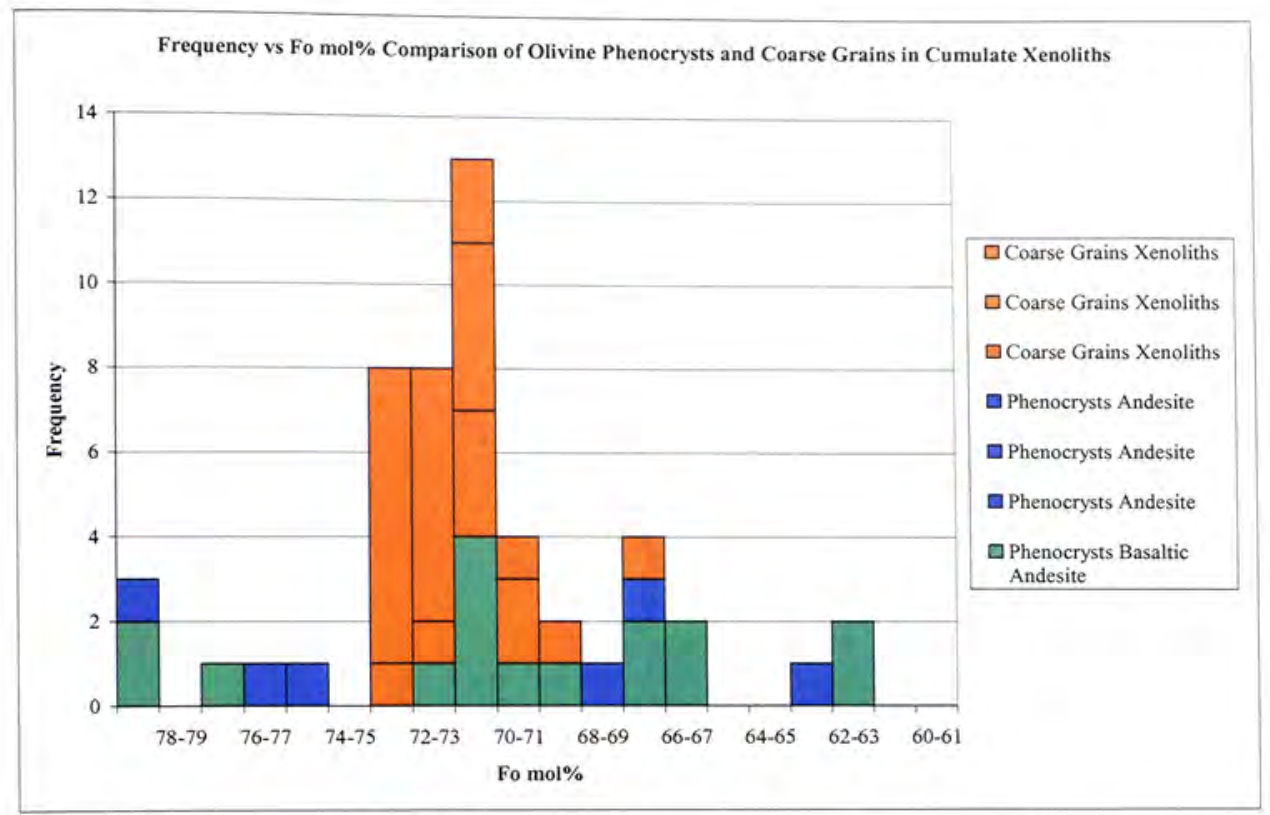

Figure 91: Composition of olivine phenocrysts and from gabbroic xenoliths. Histogram of frequency versus Fo mol\% of olivine phenocrysts compared with cumulate xenolith coarse grains.

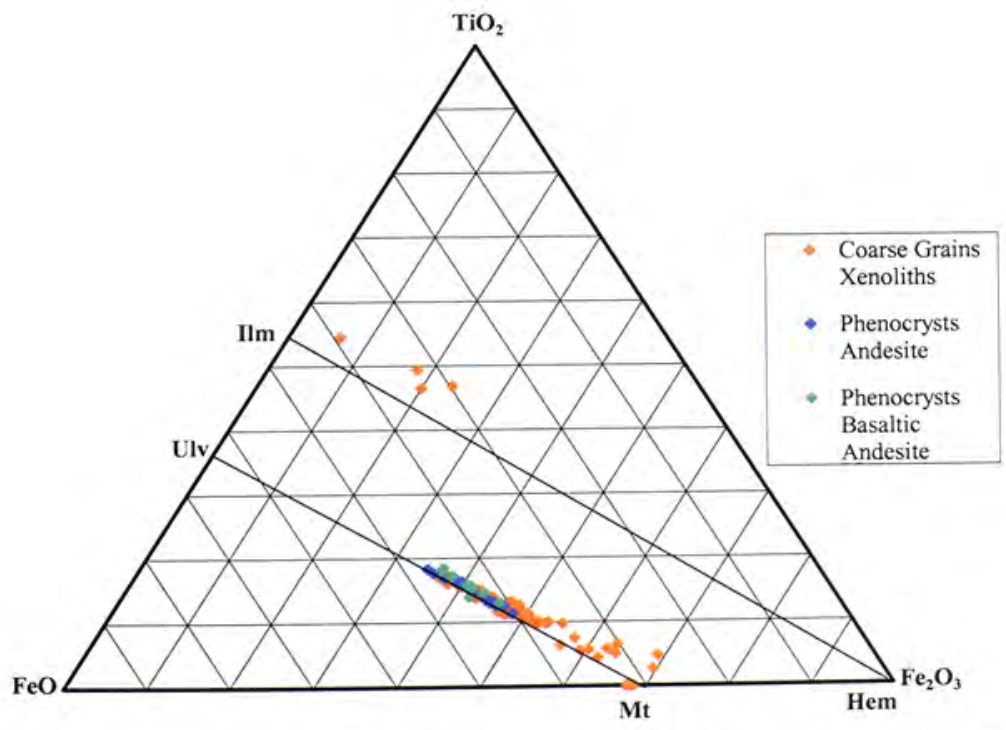

Figure 92: Composition of oxide phenocrysts and from gabbroic xenoliths.

Ternary plot of magnetite and ilmenite compositions of both phenocrysts and cumulate xenolith coarse grains. 


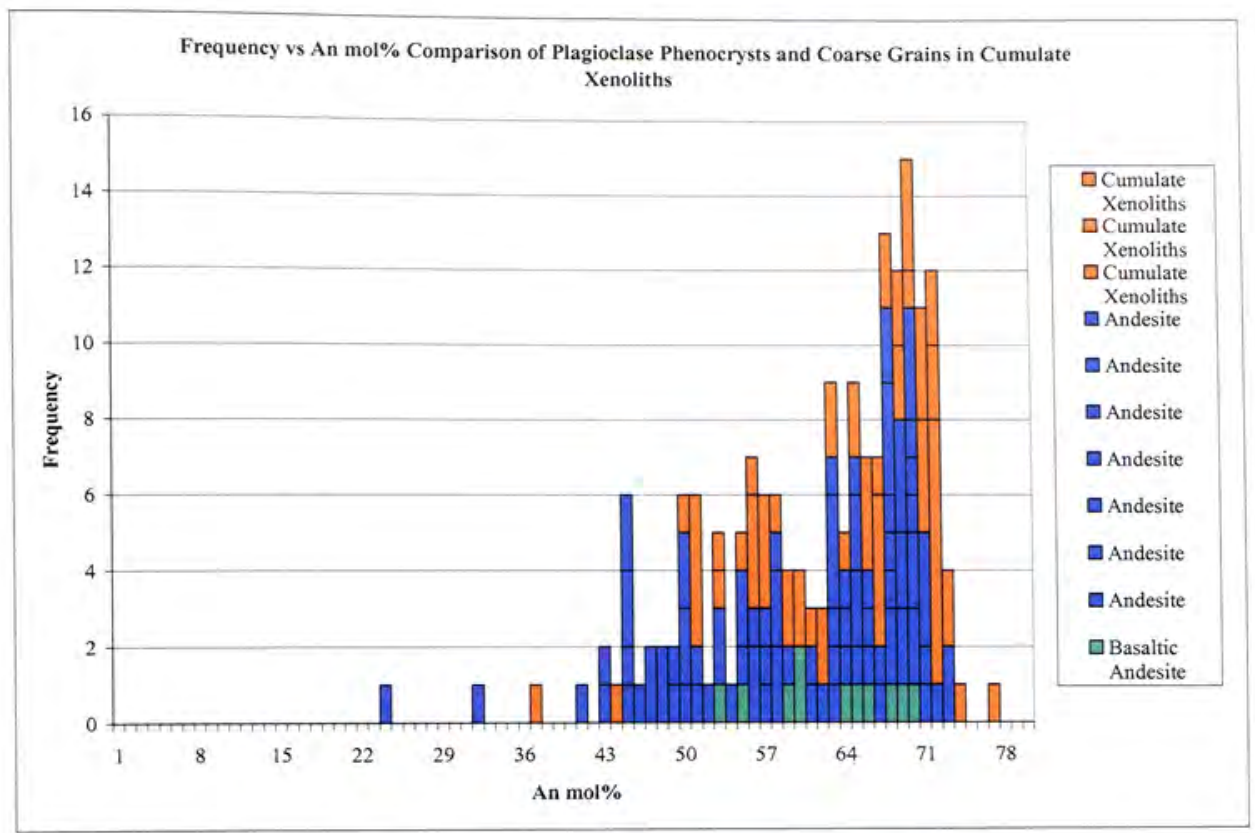

Figure 93: Composition of plagioclase phenocrysts and from gabbroic xenoliths. Histogram of frequency versus An mol\% of plagioclase phenocrysts and cumulate xenolith coarse grains.

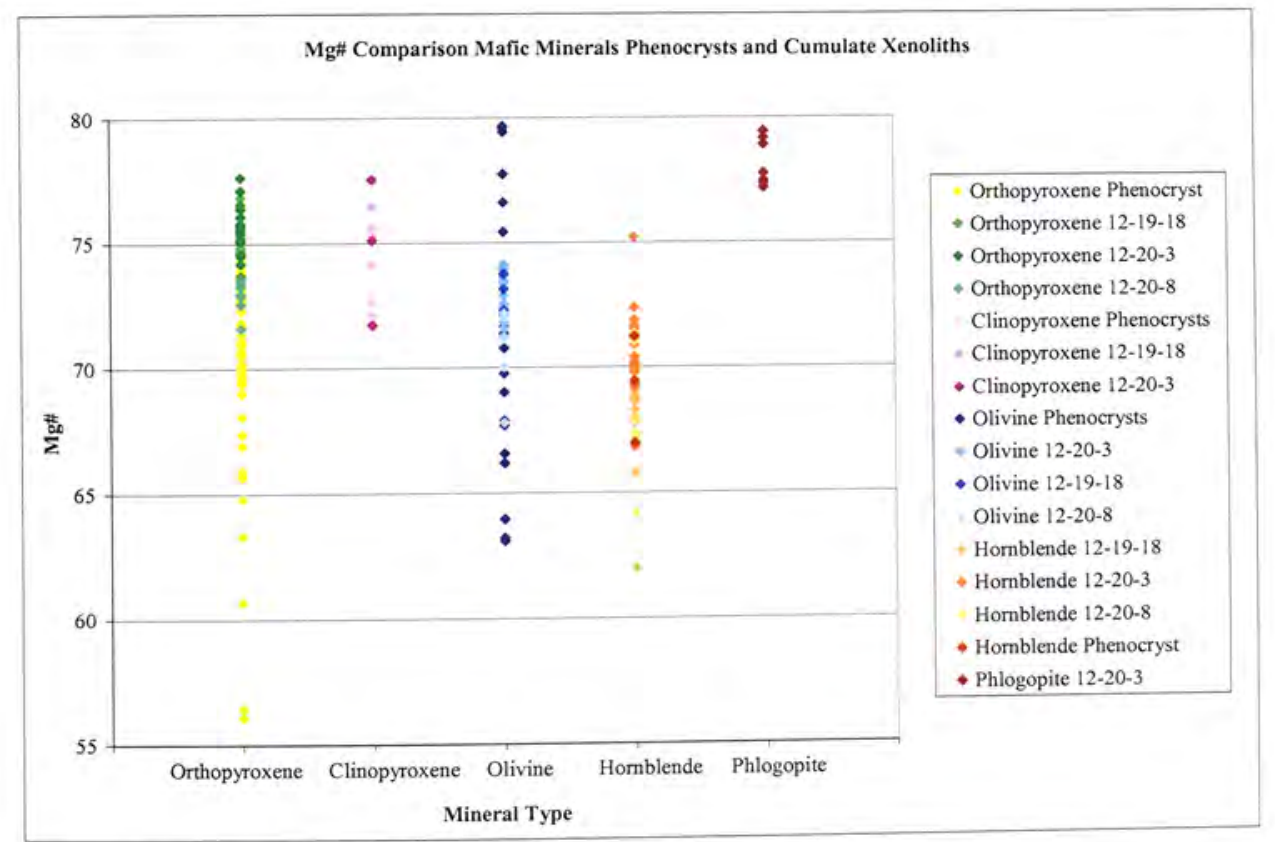

Figure 94: Mg\# of mafic phenocrysts and gabbroic phases.

Plot of the Mg-number ranges of individual mafic mineral phases of phenocrysts and cumulate xenolith coarse grains. 


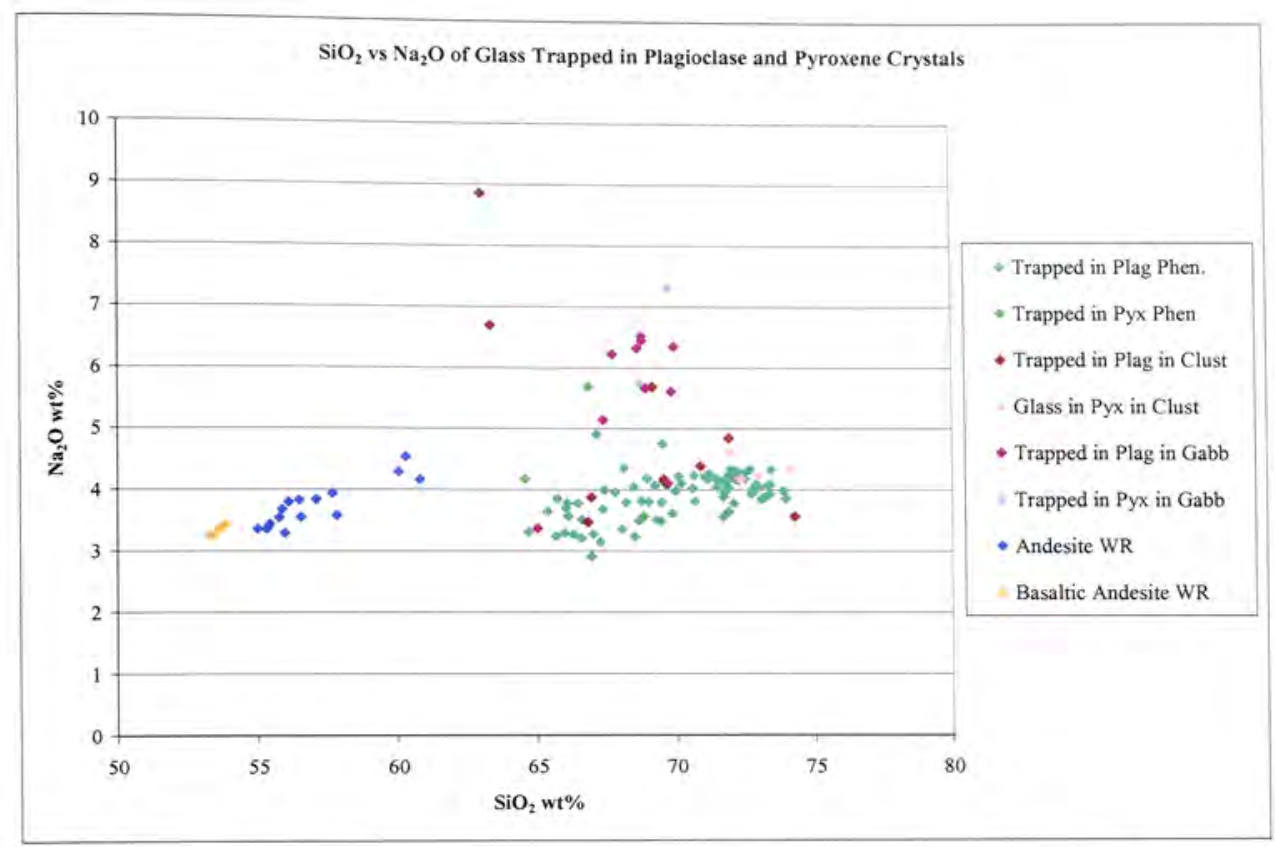

Figure 95: Volcanic glass in plagioclase and pyroxene, and interstitial glass.

Plot showing wt $\% \mathrm{Na}_{2} \mathrm{O}$ versus $\mathrm{SiO}_{2}$ of glass trapped in plagioclase and pyroxene phenocrysts and cumulate xenolith coarse grains. Overlap between glass and enclosing mineral phase may be possible for small glass pockets due to diffused beam size, therefore outlying values may be overlapped data.

Table 10: Cr concentrations of hornblende.

Calculated partition coefficient $(\mathrm{Kd})$ value ranges from $\mathrm{Cr}$ concentrations in hornblende and whole rock analyses compared with published $\mathrm{Cr} \mathrm{Kd}$ values for andesite and basaltic andesite following the formula $\mathrm{Kd}=\mathrm{Cr}^{\mathrm{min}} / \mathrm{Cr}^{\text {liq }}$. Average bulk rock $\mathrm{Cr}$ concentrations were used as liquid concentrations and hornblende concentrations used were from individual analyses of hornblende in cumulate xenoliths and one phenocryst. The range of calculated Kd values reported is compared with published Kd values for respective magma types.

\begin{tabular}{|c|c|c|c|c|}
\hline \multicolumn{6}{|c|}{ Kd Values Calculated From Cr Concentrations in Hornblende and Whole Rock Analyses } \\
Versus Published Values
\end{tabular}




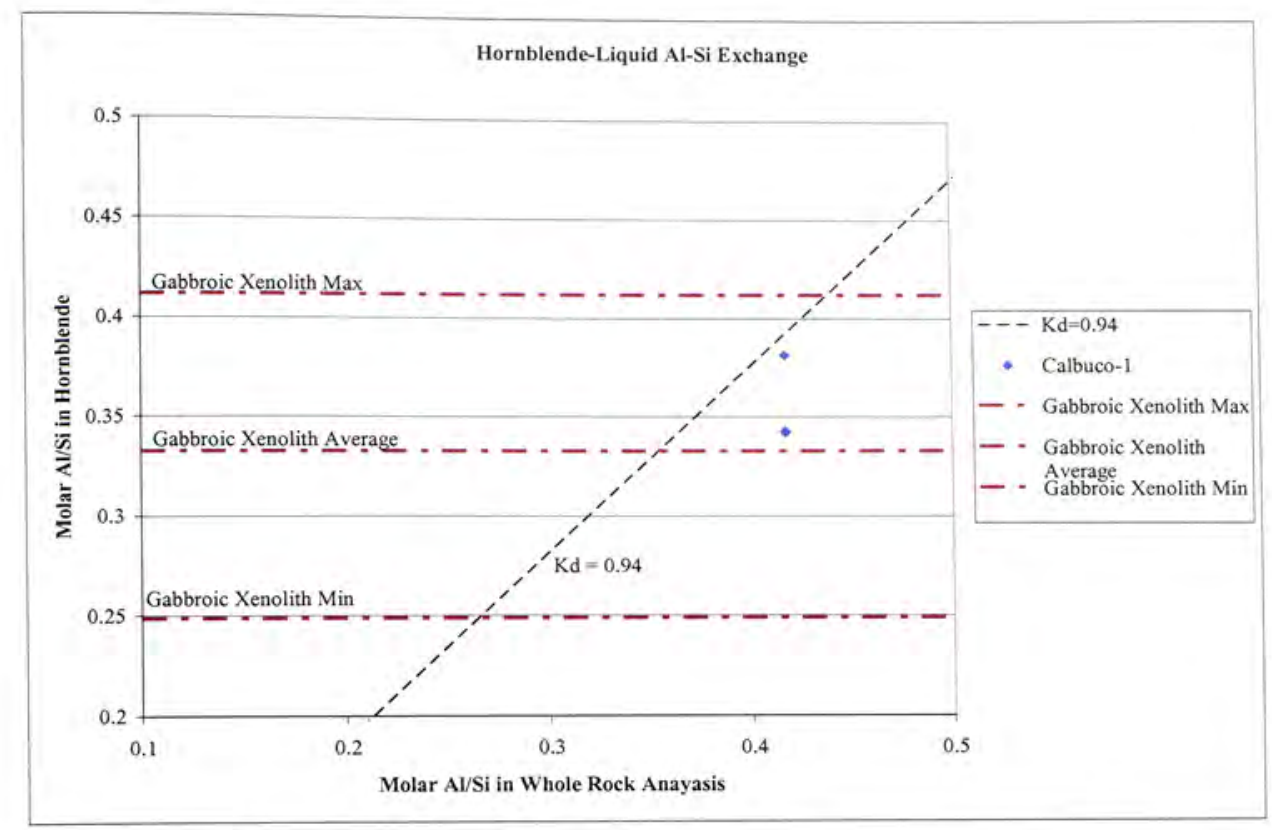

Figure 96: Al-Si exchange in hornblende.

Molar Al-Si exchange plot of $\mathrm{Al} / \mathrm{Si}$ in hornblende versus melt. $\mathrm{Kd}$ value for hornblende in equilibrium with high- $\mathrm{Al}_{2} \mathrm{O}_{3}$ basalt to rhyolite (Sisson and Grove, 1993a).

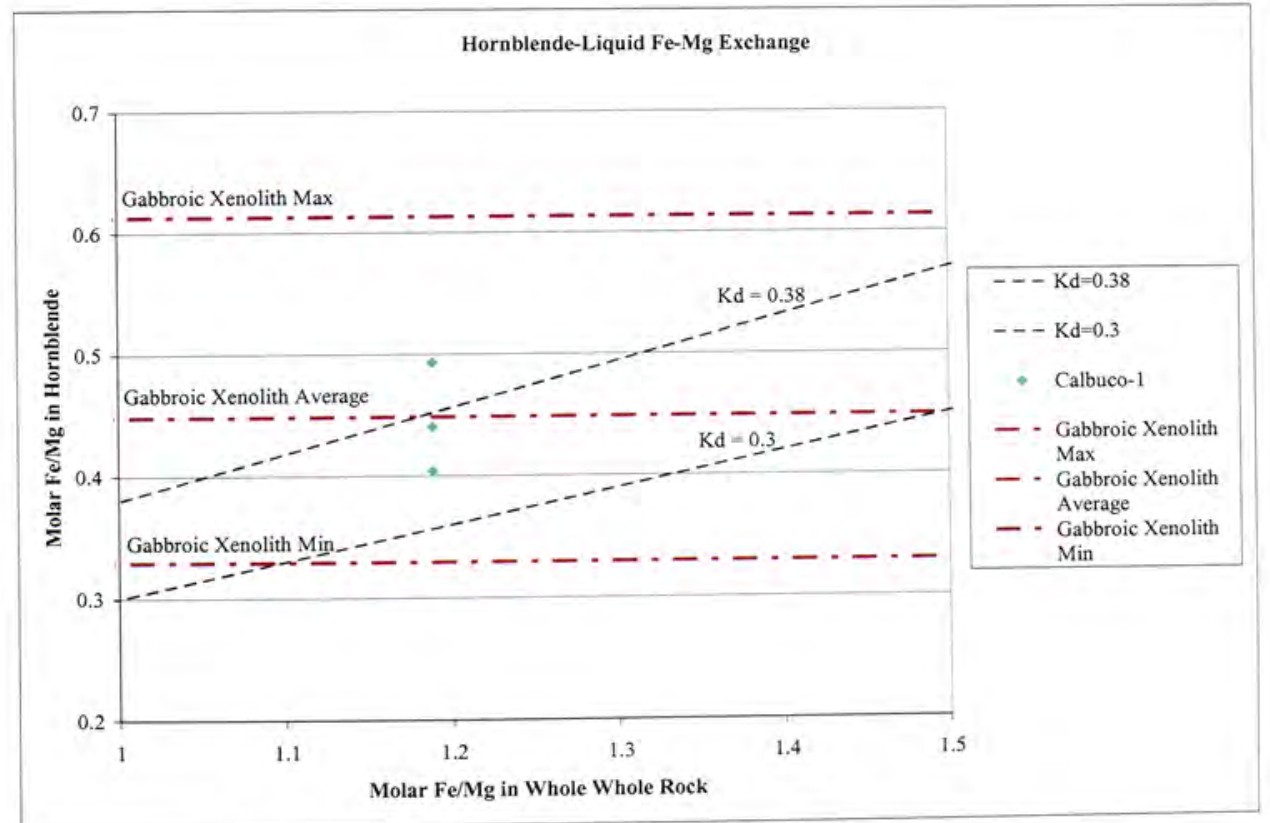

Figure 97: Fe-Mg exchange in hornblende.

Molar $\mathrm{Fe}-\mathrm{Mg}$ exchange plot of $\mathrm{Fe} / \mathrm{Mg}$ in hornblende versus melt. $\mathrm{Fe}$ is total iron. $\mathrm{Kd}$ value for hornblende in equilibrium with high- $\mathrm{Al}_{2} \mathrm{O}_{3}$ basalt to andesite (Sisson and Grove, 1993a). 


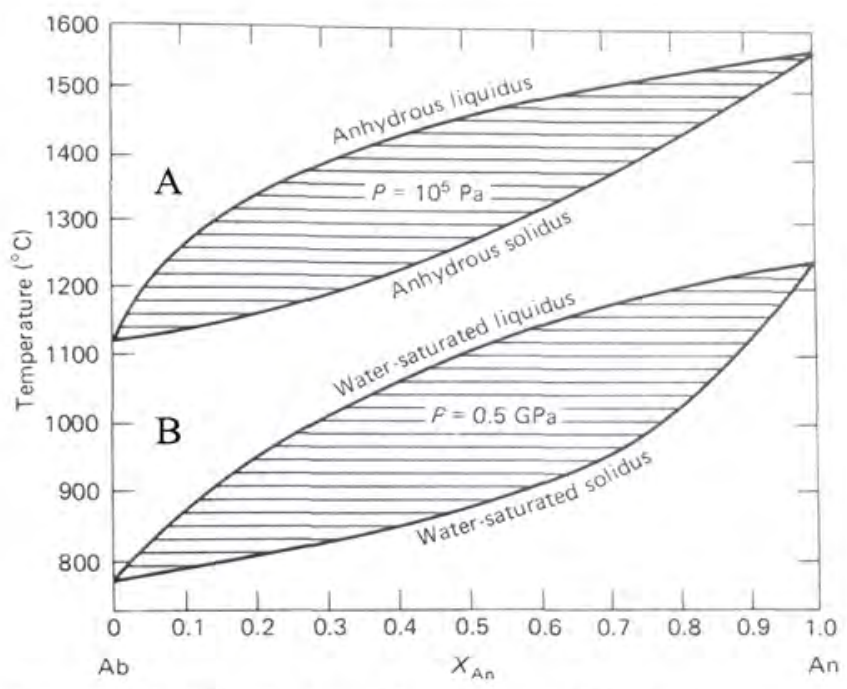

Figure 98: Plagioclase liquidus-solidus loop.

Plagioclase phase diagram showing the positions of the solidus and liquidus under anhydrous (A) and hydrous (B) conditions. Water saturation depresses the solidus causing more calcic plagioclase to crystallize at lower temperatures. Diagram from Philpotts, 1990.

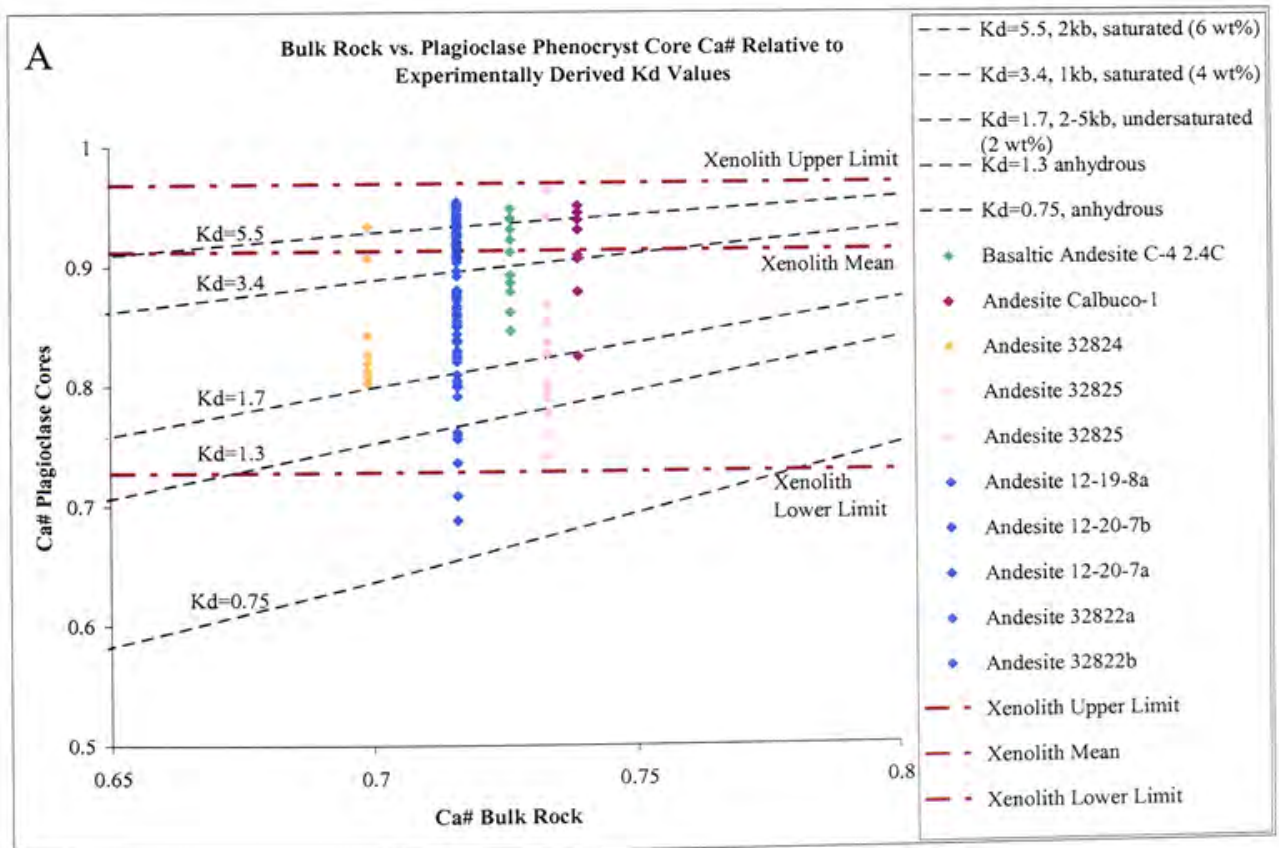



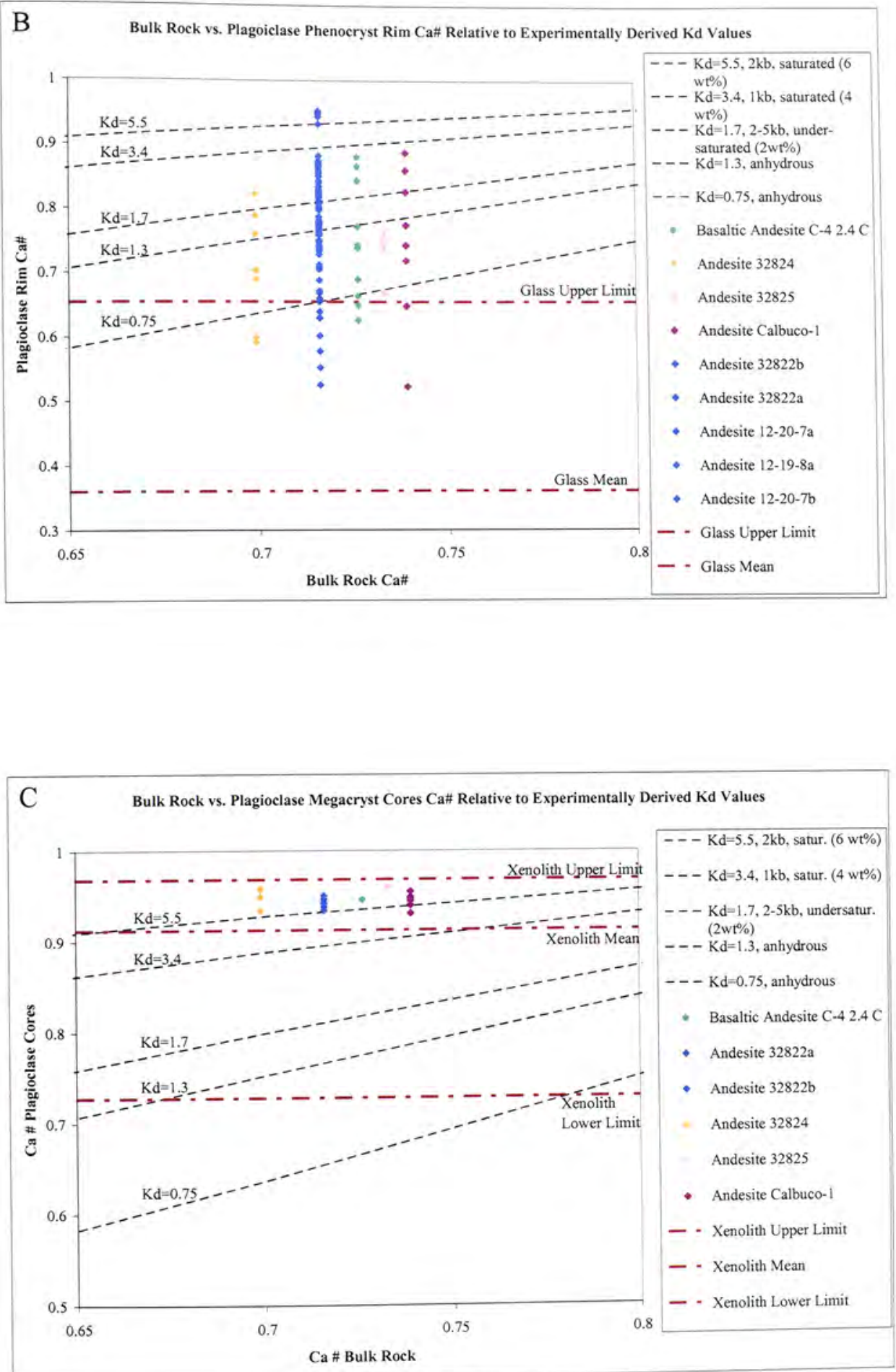


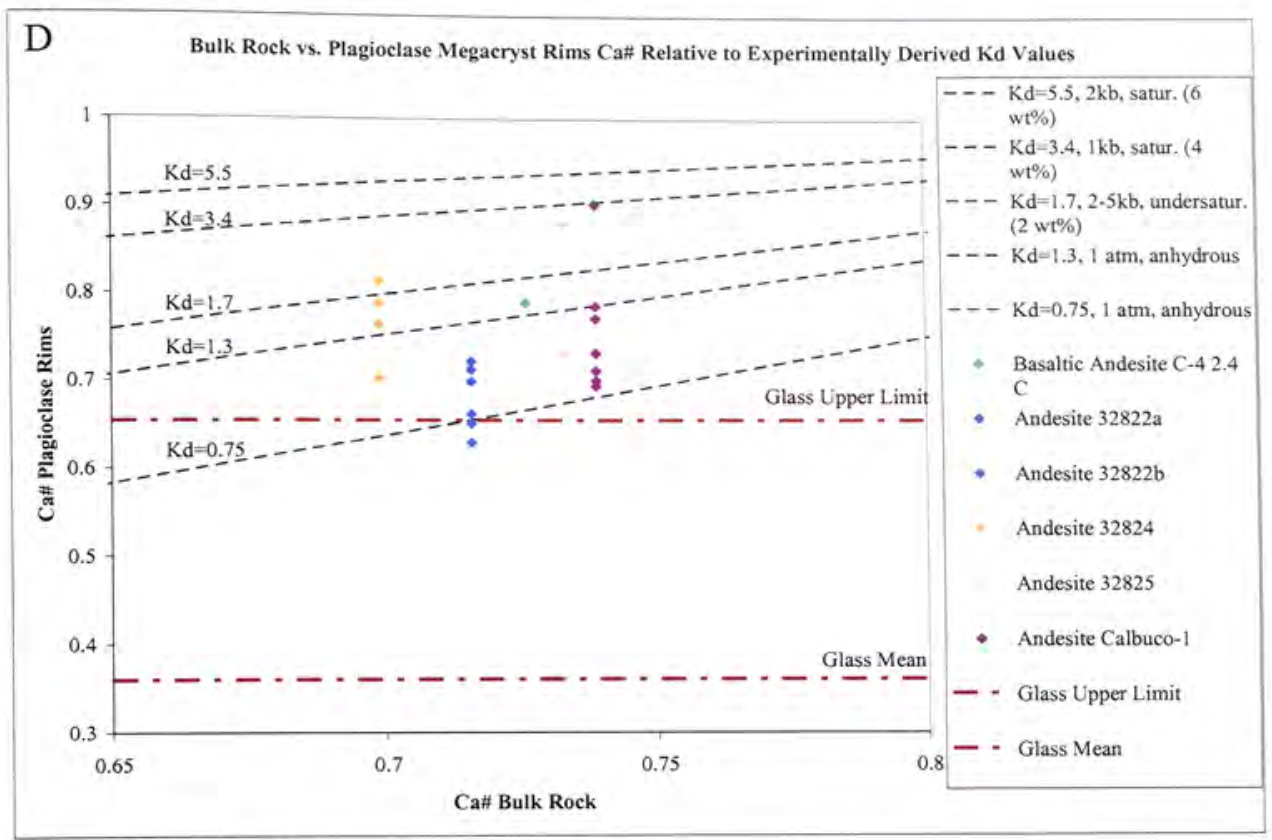

Figure 99: $\mathrm{Ca}-\mathrm{Na}$ exchange in plagioclase phenocrysts and megacrysts.

$\mathrm{Ca} \#[\mathrm{molar} \mathrm{Ca} /(\mathrm{Ca}+\mathrm{Na})]$ of the plagioclase grains versus. Ca\# of the bulk rock analyses. Upper and lower limits, along with the majority, of the Ca\# of the plagioclase grains in the entrained gabbros and upper limits and majority values of the Ca\# of volcanic glass are also shown. Experimentally derived $\mathrm{Kd}$ values $\left[\mathrm{Kd}=\left(\mathrm{Ca} / \mathrm{Na}\right.\right.$ plag $\left./(\mathrm{Ca} / \mathrm{Na})_{\text {liq }}\right]$ (Sisson and Grove, 1993a) from water bearing calc-alkaline rocks have been plotted to constrain the magmatic conditions. The $\mathrm{Kd}$ values correspond to different pressure conditions and water weight percentages: $\mathrm{Kd}=5.5$ is at $2 \mathrm{~kb}$, water saturated, with $6 \mathrm{wt} \% \mathrm{H}_{2} \mathrm{O}, \mathrm{Kd}=3.4$ is at $1 \mathrm{~kb}$, water saturated, with $4 \mathrm{wt} \% \mathrm{H}_{2} \mathrm{O}$, and 1.7 is from $2-5 \mathrm{~kb}$, water under-saturated, with $2 \mathrm{wt} \% \mathrm{H}_{2} \mathrm{O}$. (A) Ca\# of the cores of the zoned plagioclase crystals with the upper and lower limits and majority of the cores of the plagioclase in the entrained gabbros; (B) $\mathrm{Ca}$ of the rims of the zoned plagioclase grains; (C) Ca\# of the cores of the plagioclase megacrysts with the upper and lower limits and majority of the cores of the plagioclase in the entrained gabbros; (D) Ca\# of the rims of the plagioclase megacrysts. Diagram and anhydrous Kd values after Rodriquez-Durand and Sen, 2004. 


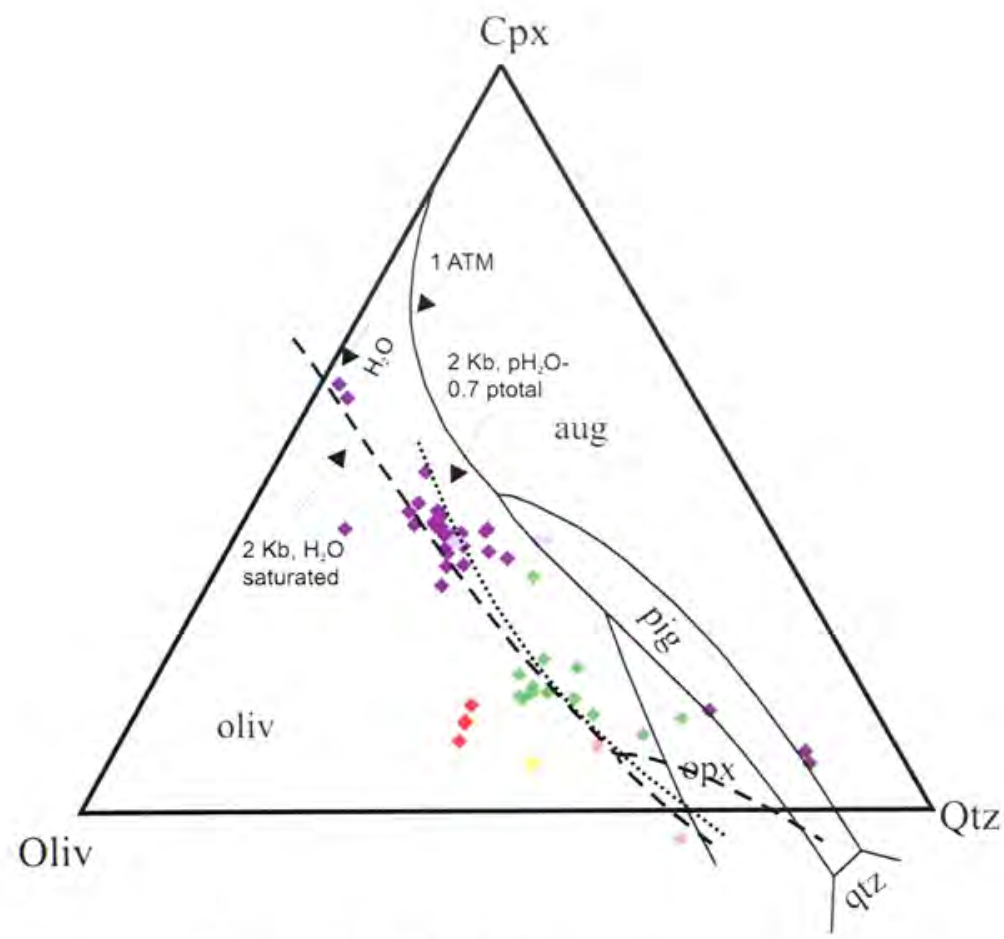

Figure 100: Ternary Cpx-Ol-Qtz phase diagram.

Ternary Cpx-Ol-Qtz phase diagram projected from plagioclase with atmospheric and 2 kbars hydrous cotectics plotted. 2 kbar cotectics are at water saturation as well as undersaturation. Olivine, orthopyroxene, clinopyroxene, pigeonite, and quartz stability fields are shown. Cotectics, from Grove et al. (1983) at atmospheric pressure and Sisson and Grove (1993a) at 2 kbar pressure, decrease the size of the olivine stability field and eliminate the pigeonite stability field with increased dissolved water content. Eruptive products from Calbuco and Osorno are shown. Osorno basalt, basaltic andesite, and dacite are dark purple diamonds. Light purple diamonds represent a calculated composition after subtraction of $30 \%$ gabbroic mineral assemblage from Osorno basalt (López-Escobar et al., 1995). Green diamonds are andesitic lava flows from Calbuco, tan diamonds are Calbuco fallout deposits (andesite), yellow diamonds are Calbuco surge deposits (andesite), and red diamonds are basaltic andesite debris and pyroclastic flows from Calbuco. 


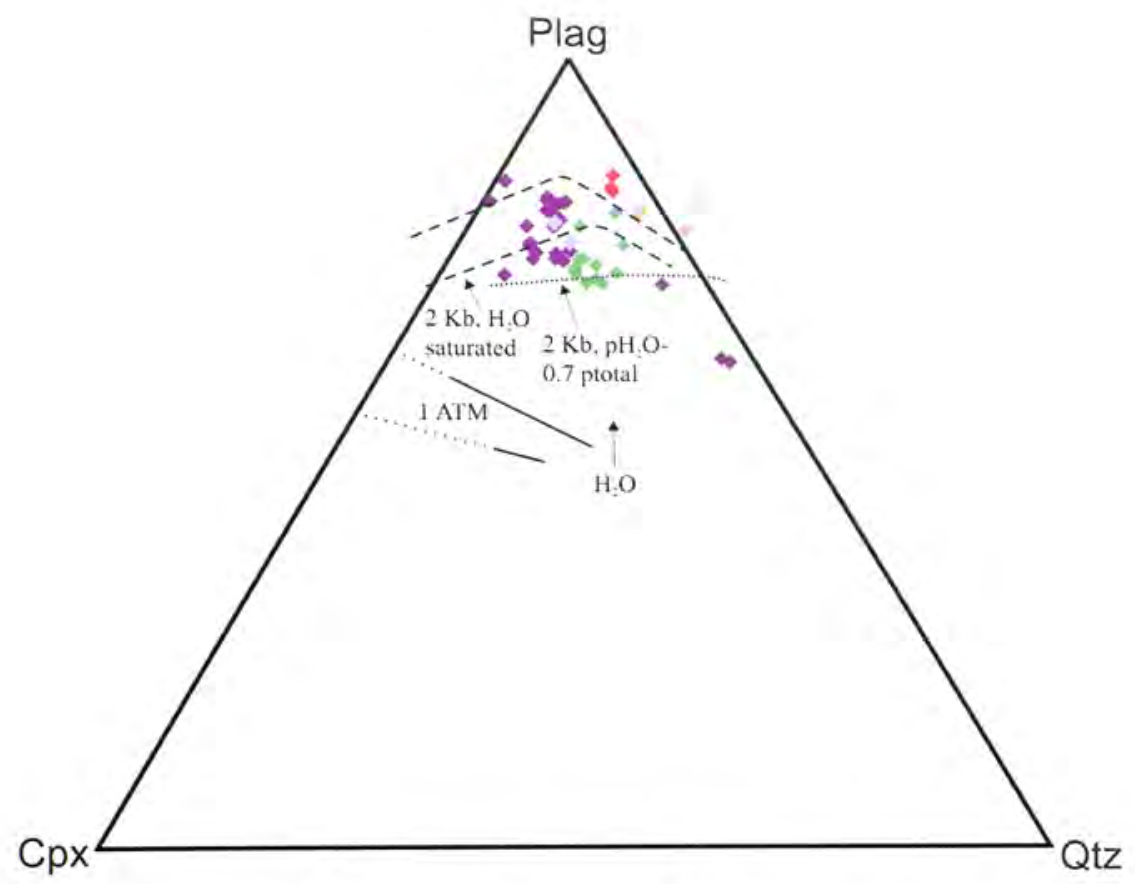

Figure 101: Ternary Plag-Cpx-Qtz phase diagram.

Ternary Plag-Cpx-Qtz phase diagram projected from olivine with atmospheric and 2 kbars hydrous cotectics plotted. 2 kbar cotectics are at water saturation or $\mathrm{pH}_{2} \mathrm{O}$ at $0.7 \%$ total pressure. Cotectics, from Sisson and Grove (1993a) at atmospheric pressure and at $2 \mathrm{kbar}$ pressure, shift in the direction of plagioclase with increased dissolved water content. Eruptive products from Calbuco and Osorno are shown. Osorno basalt, basaltic andesite, and dacite are dark purple diamonds. Light purple diamonds represent a calculated composition after subtraction of $30 \%$ gabbroic mineral assemblage from Osorno basalt (López-Escobar et al., 1995). Green diamonds are andesitic lava flows from Calbuco, tan diamonds are Calbuco fallout deposits (andesite), yellow diamonds are Calbuco surge deposits (andesite), and red diamonds are basaltic andesite debris and pyroclastic flows from Calbuco. 


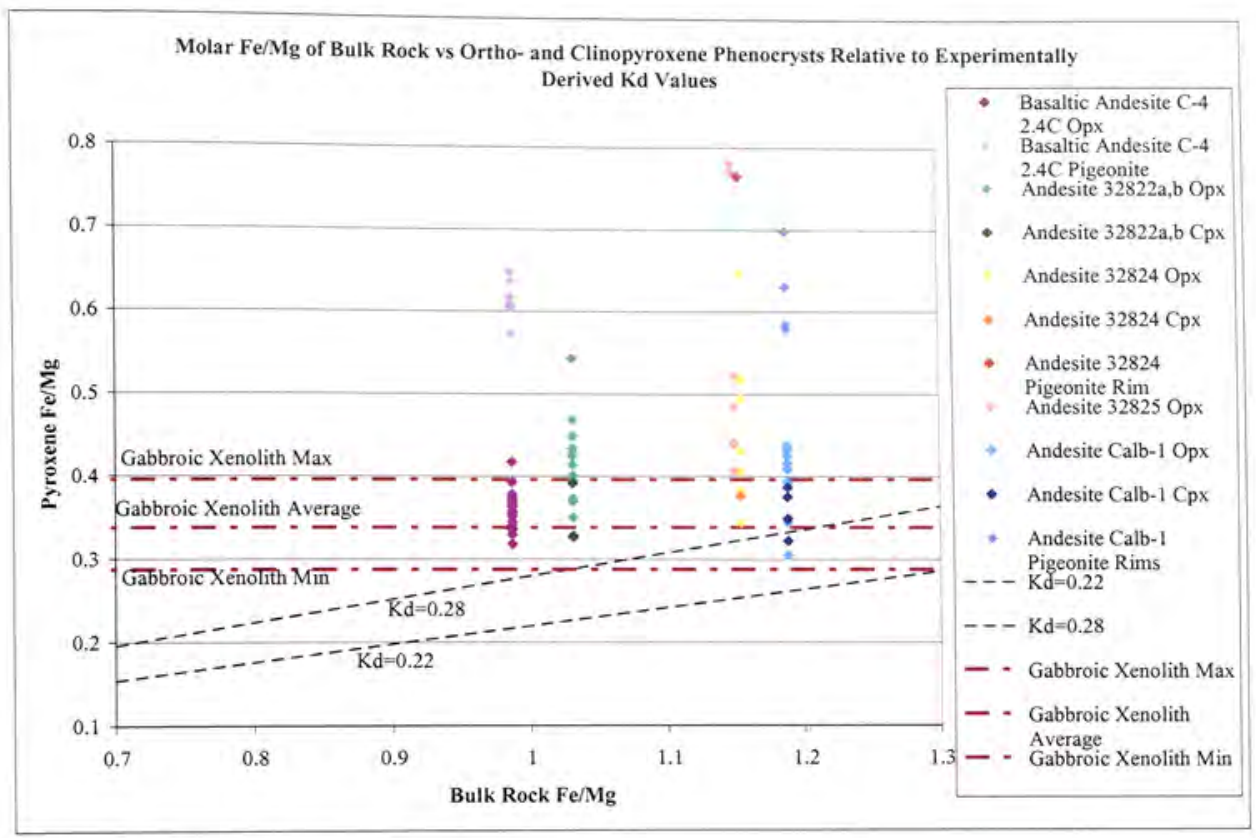

Figure 102: Fe-Mg exchange in pyroxene.

$\mathrm{Molar} \mathrm{Fe} / \mathrm{Mg}$ of the orthopyroxene, clinopyroxene, and pigeonite grains versus. $\mathrm{Fe} / \mathrm{Mg}$ of the bulk rock analyses. Upper and lower limits, along with the majority, of the $\mathrm{Fe} / \mathrm{Mg}$ of the pyroxene grains in the entrained gabbros are also shown. Experimentally derived $\mathrm{Kd}$ values $\left[\mathrm{Kd}=\left(\mathrm{Fe} / \mathrm{Mg}_{\text {pyx }} /(\mathrm{Fe} / \mathrm{Mg})_{\text {liq }}\right]\right.$ (Sisson and Grove, 1993a) from water bearing calcalkaline rocks have been plotted to constrain the magmatic conditions. 


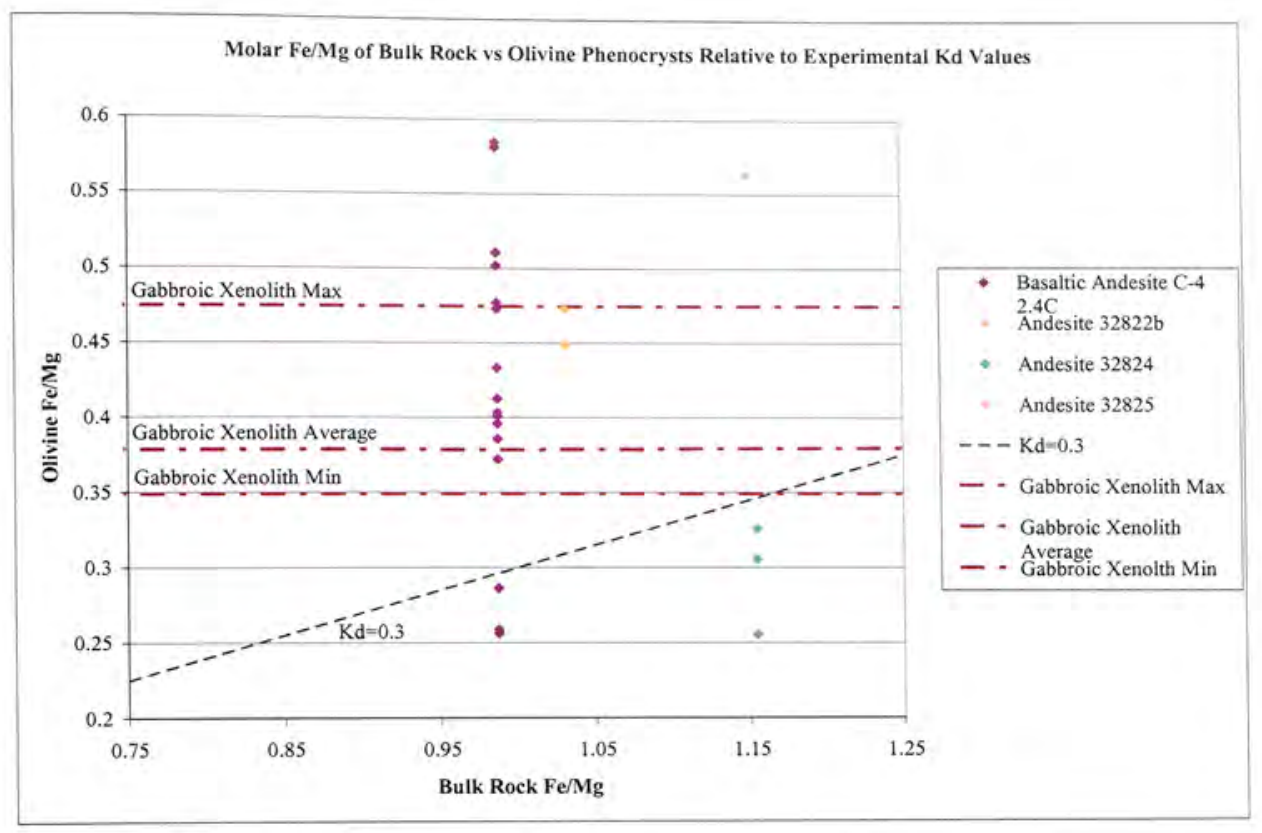

Figure 103: Fe-Mg exchange in olivine.

Molar $\mathrm{Fe} / \mathrm{Mg}$ of the olivine grains versus. $\mathrm{Fe} / \mathrm{Mg}$ of the bulk rock analyses. Upper and lower limits, along with the majority, of the $\mathrm{Fe} / \mathrm{Mg}$ of the olivine grains in the entrained gabbros are also shown. Experimentally derived $\mathrm{Kd}$ values $\left[\mathrm{Kd}=\left(\mathrm{Fe} / \mathrm{Mgol} /(\mathrm{Fe} / \mathrm{Mg})_{\text {liq }}\right]\right.$ (Sisson and Grove, 1993a) from water bearing calc-alkaline rocks have been plotted to constrain the magmatic conditions.

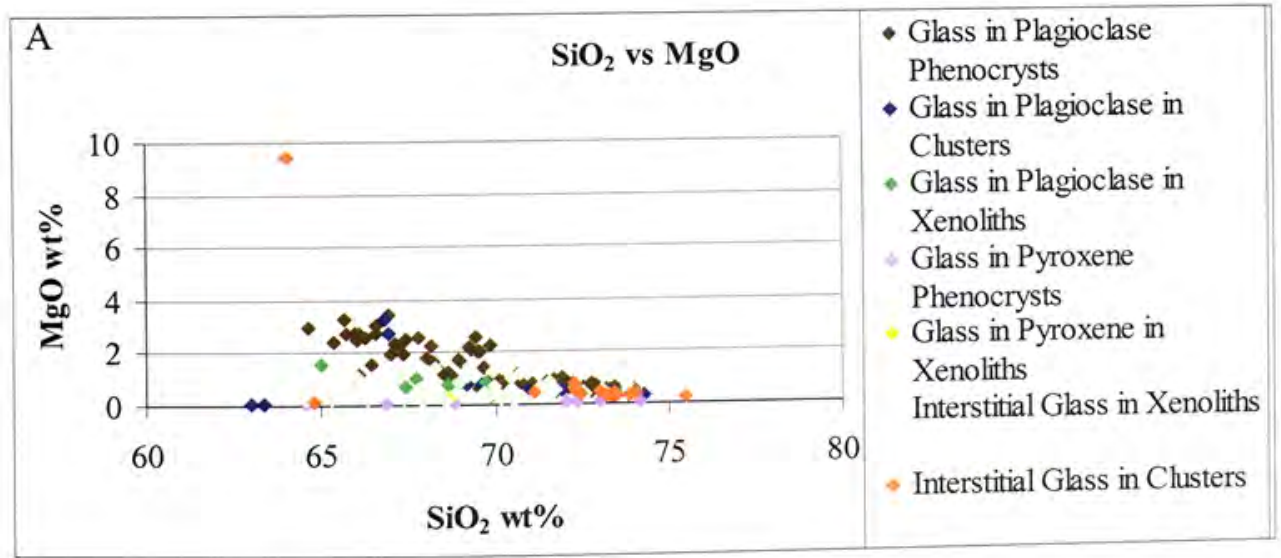




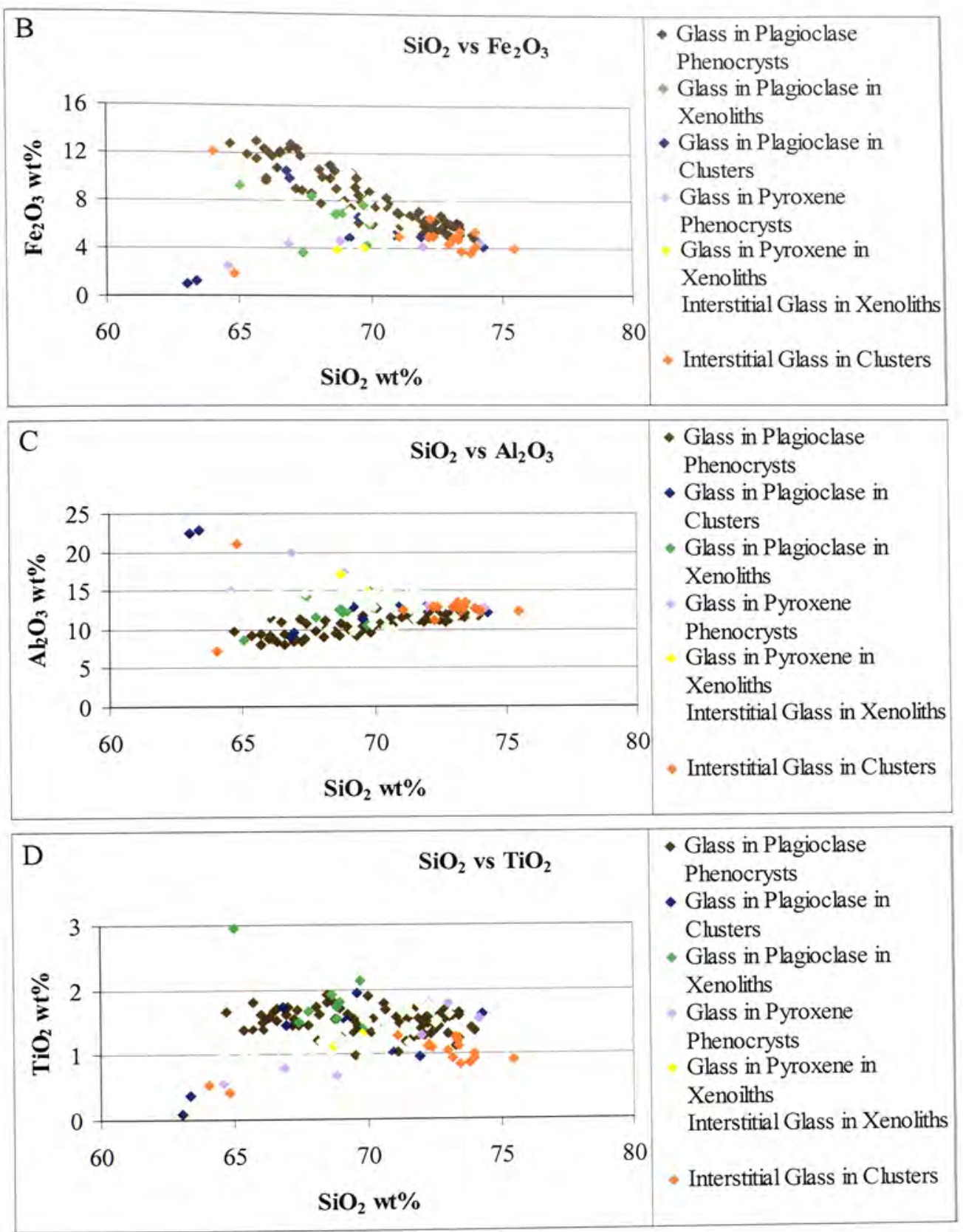



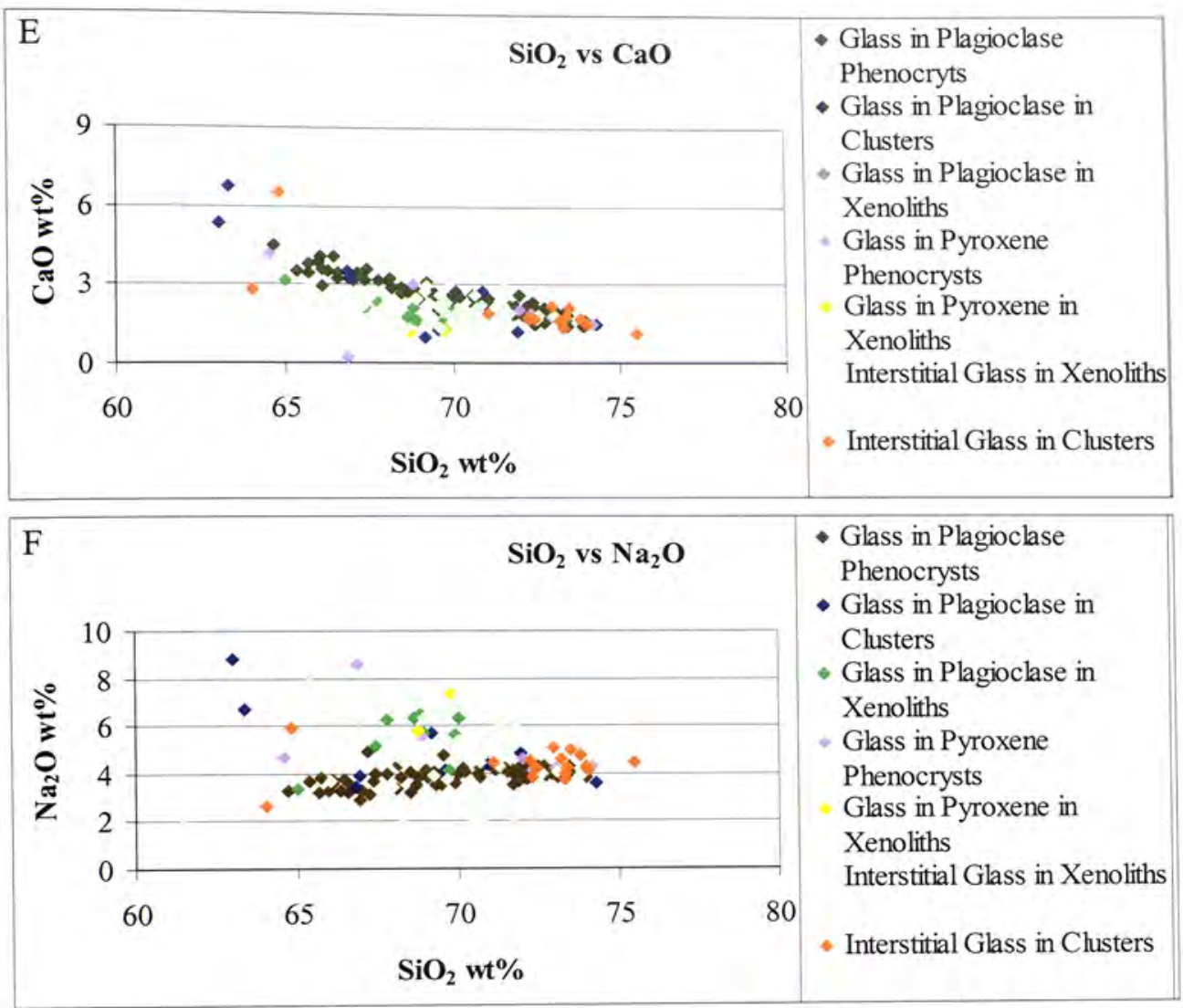

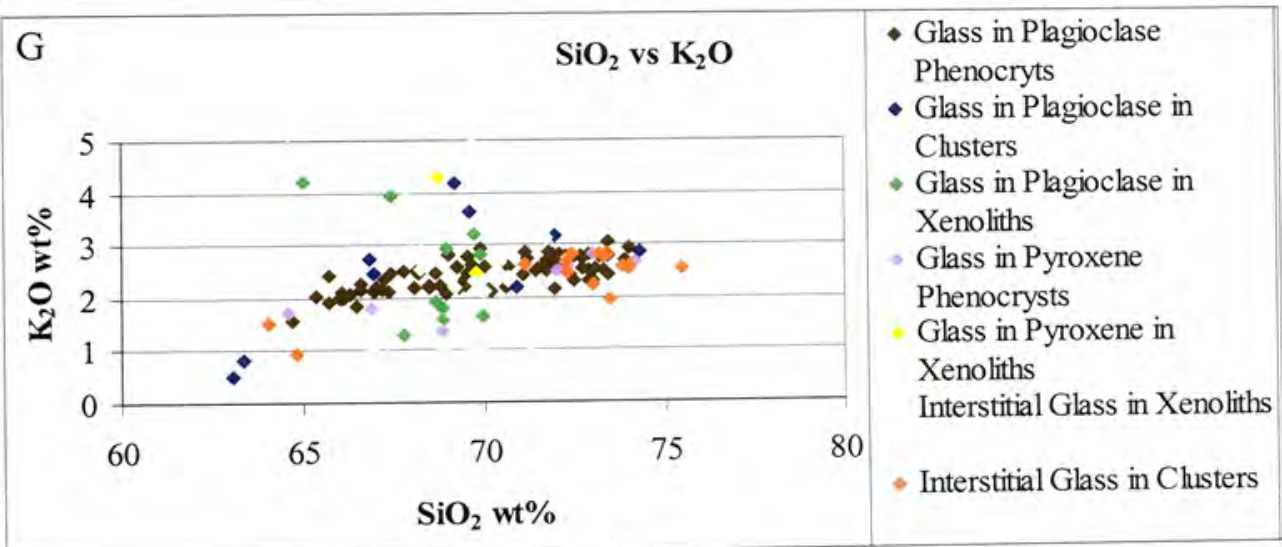




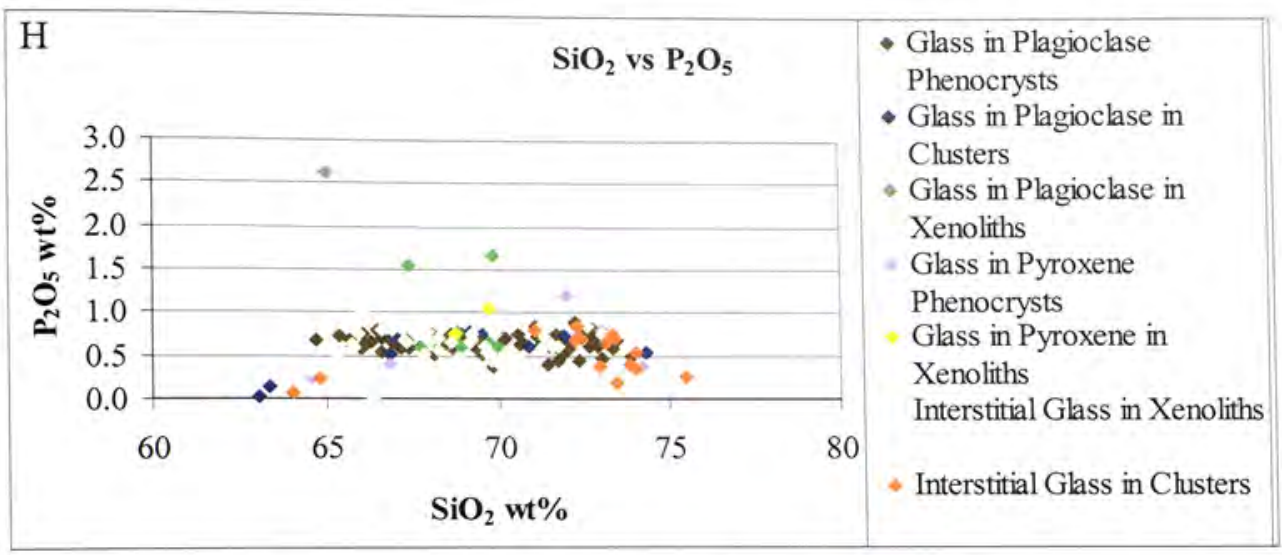

Figure 104: Bulk analysis of glass in plagioclase, pyroxene, and interstitial glass.

Plot comparing wt $\%$ oxides $\left(\mathrm{MgO}, \mathrm{Fe}_{2} \mathrm{O}_{3}, \mathrm{Al}_{2} \mathrm{O}_{3}, \mathrm{TiO}_{2}, \mathrm{CaO}, \mathrm{Na}_{2} \mathrm{O}, \mathrm{K}_{2} \mathrm{O}\right.$, and $\mathrm{P}_{2} \mathrm{O}_{5}$ ) versus $\mathrm{wt} \% \mathrm{SiO}_{2}$ for bulk analysis of glass trapped in plagioclase phenocrysts, plagioclase in crystal clusters and cumulate xenoliths, pyroxene phenocrysts and coarse grains in cumulate xenoliths, and interstitial glass in crystal clusters and cumulate xenoliths. Glass analyses have been screened for crystal structure, however outlying data points may be overlap, due to use of a defocused beam on the electron microprobe, between the glass and host crystals or post entrapment crystals.

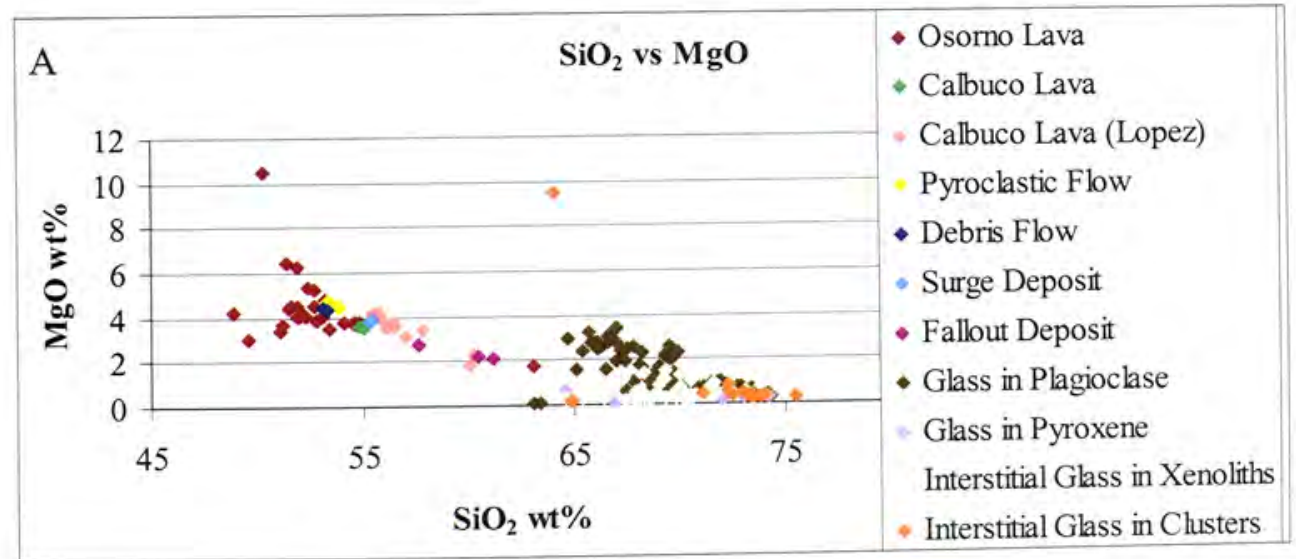



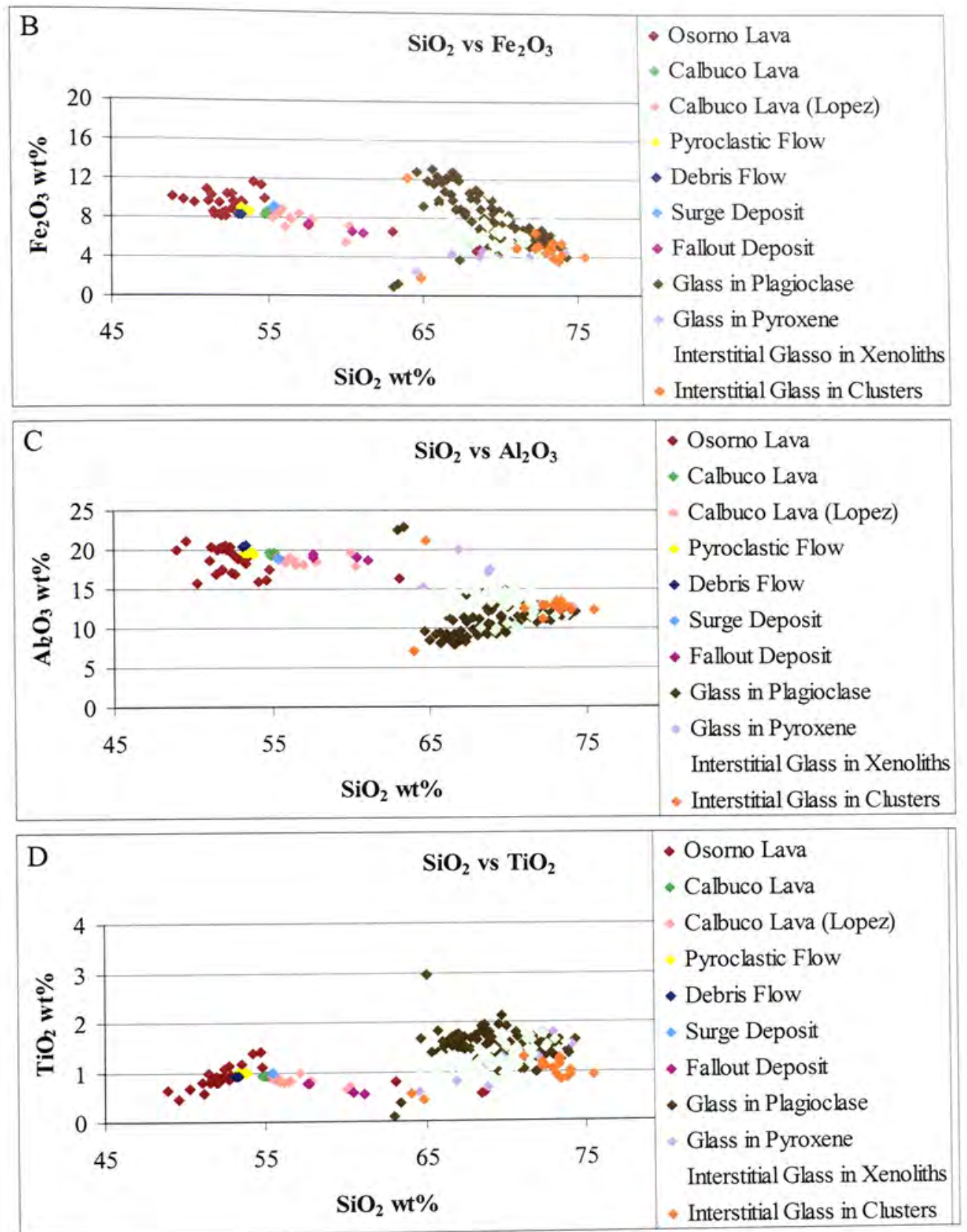

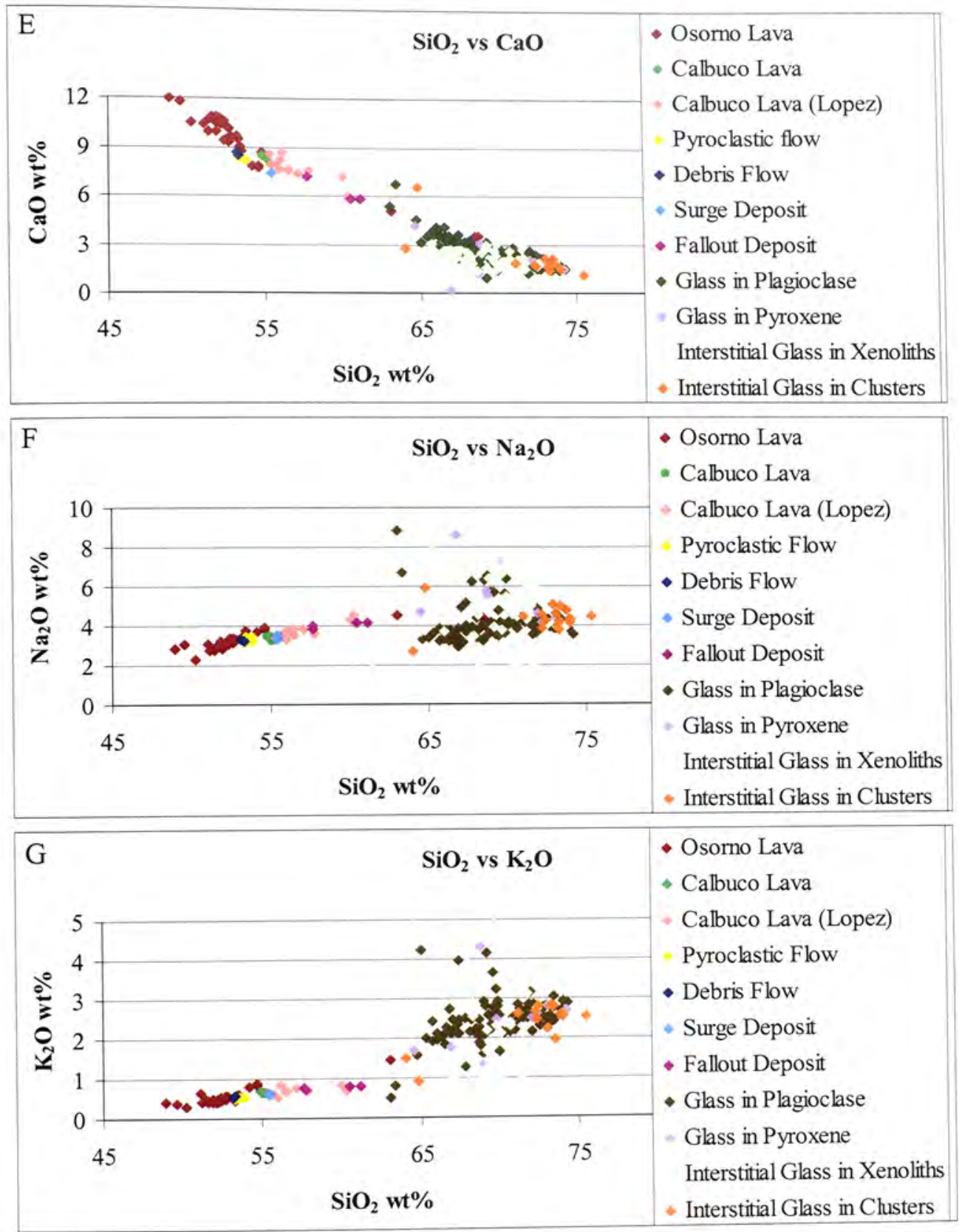


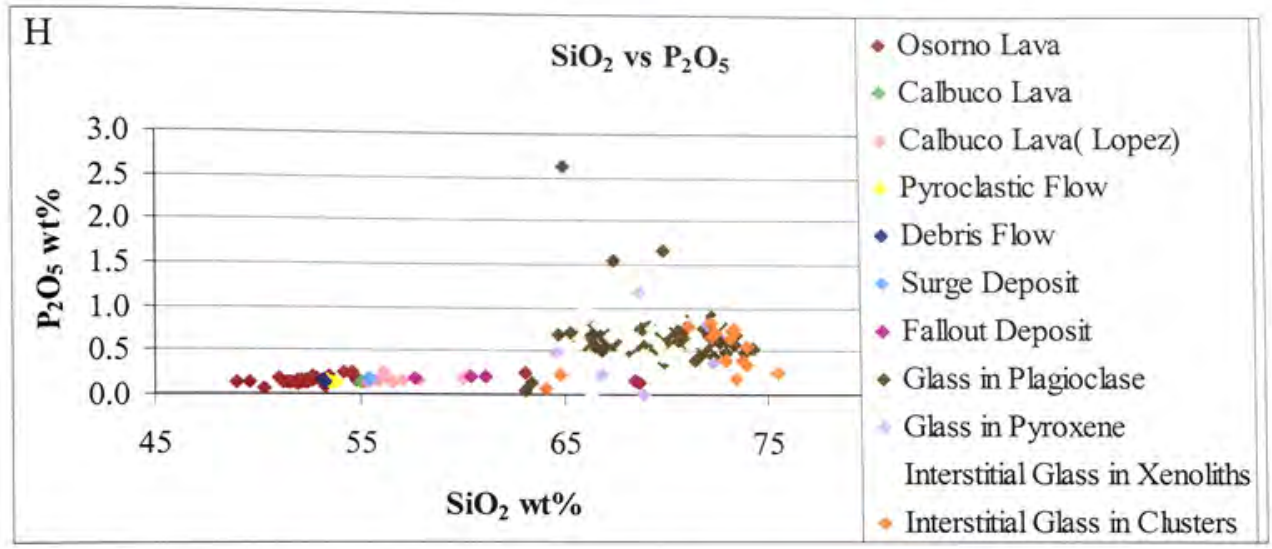

Figure 105: Bulk analysis of glass and Calbuco and Osorno eruptive products.

Plot comparing wt $\%$ oxides $\left(\mathrm{MgO}, \mathrm{Fe}_{2} \mathrm{O}_{3}, \mathrm{Al}_{2} \mathrm{O}_{3}, \mathrm{TiO}_{2}, \mathrm{CaO}, \mathrm{Na}_{2} \mathrm{O}, \mathrm{K}_{2} \mathrm{O}\right.$, and $\left.\mathrm{P}_{2} \mathrm{O}_{5}\right)$ versus $\mathrm{wt} \% \mathrm{SiO}_{2}$ for bulk analysis of glass trapped in plagioclase phenocrysts, plagioclase in crystal clusters and cumulate xenoliths, pyroxene phenocrysts and coarse grains in cumulate xenoliths, and interstitial glass in crystal clusters and cumulate xenoliths compared with bulk analyses of Calbuco and Osorno lavas, Calbuco pyroclastic and debris flows, and Calbuco fallout and surge deposits. Glass analyses have been screened for crystal structure, however outlying data points may be overlap, due to use of a defocused beam on the electron microprobe, between the glass and host crystals or post entrapment crystals. 


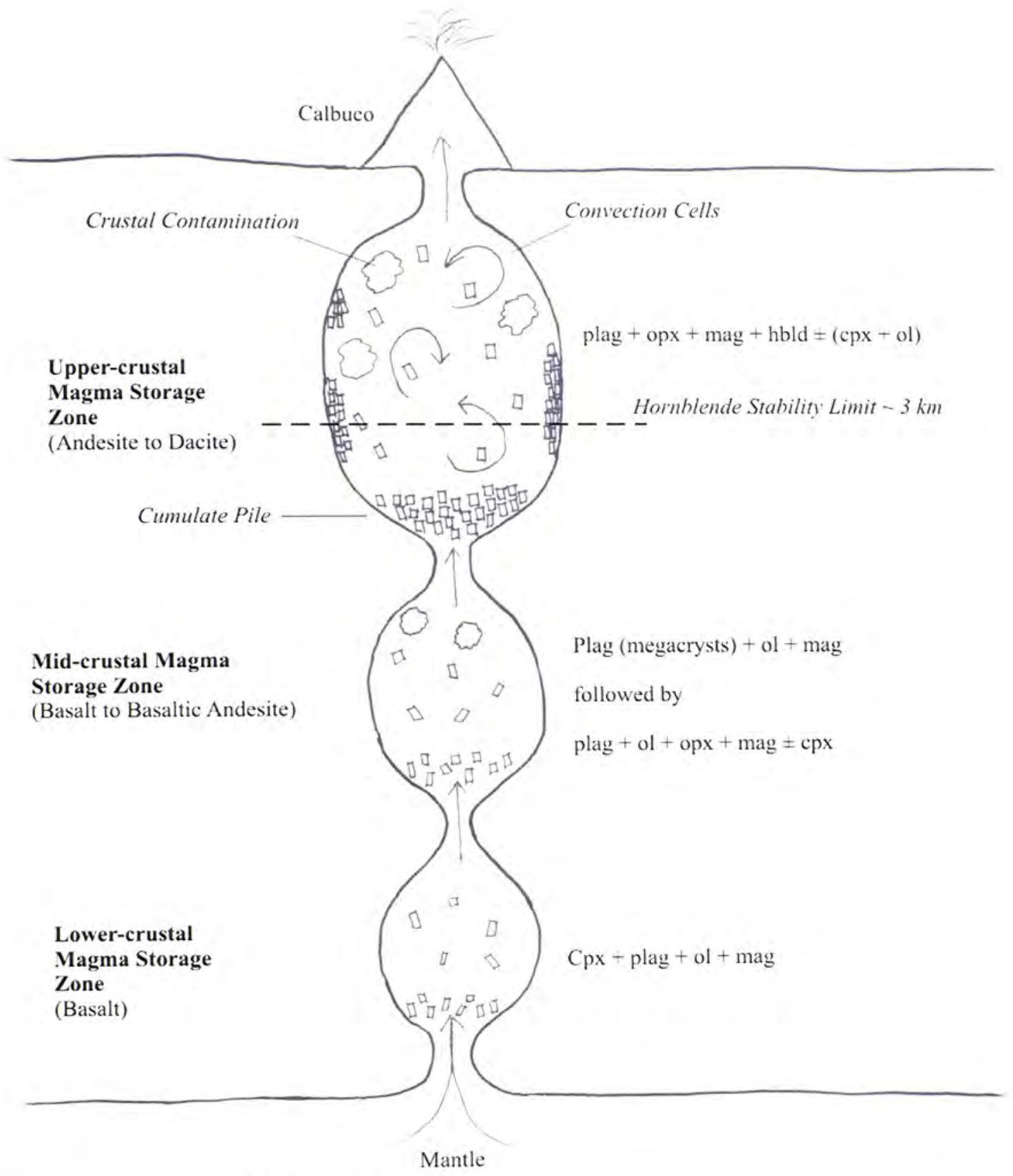

Figure 106: Sketch of Calbuco Magma Storage Zones.

Sketch is not to scale.

Caption on following page. 
Schematic drawing of Calbuco magma storage zones (not drawn to scale). 1) Basalt feeds lower-crustal magma storage zone and fractionates clinopyroxene, plagioclase, olivine, and magnetite to become high- $\mathrm{Al}_{2} \mathrm{O}_{3}$ basalt (HAB).

2) $\mathrm{HAB}$ feeds mid-crustal magma storage zone, clinopyroxene crystallization diminishes, $\mathrm{HAB}$ fractionates plagioclase megacrysts, olivine and magnetite to become high- $\mathrm{Al}_{2} \mathrm{O}_{3}$ basaltic andesite (HABA).

3) HABA fractionates plagioclase, olivine, magnetite, orthopyroxene, and possibly clinopyroxene.

4) HABA feeds upper-crustal magma storage zone and fractionates plagioclase, orthopyroxene, magnetite, hornblende, and possibly clinopyroxene and olivine to become andesite, andesite differentiates possibly as far as dacite between inputs of HABA during recharge events. 


\section{Chapter 8. Conclusions}

Calbuco Volcano, at $41^{\circ} 20^{\prime} \mathrm{S}$ latitude, in the Central Southern Volcanic Zone (CSVZ) in Southern Chile is a predominantly andesitic volcanic center in contrast to the many basaltic volcanic centers which surround it. In addition to being andesitic, Calbuco's eruptive products contain gabbroic cumulate and granulitic xenoliths and phenocrysts of hornblende. This thesis has generated the following conclusions relating to the origin of these features.

\subsection{Hornblende Crystallization}

Results of this work suggest that hornblende crystallizes from Calbuco magmas starting at basaltic andesite to andesitic compositions. Two new lines of evidence support this. First, hornblende phenocryst compositions are in equilibrium with the andesite liquid. Partition coefficients for the exchange of $\mathrm{Al}-\mathrm{Si}$ and $\mathrm{Fe}-\mathrm{Mg}$ in high-alumina basalt to rhyolite and high-alumina basalt to andesite respectively demonstrate the existence of equilibrium between hornblende phenocrysts and the lava. Plots of both element pairs show the analyzed hornblende phenocryst to be in equilibrium with the lava. Second, lavas have characteristics that are consistent with hornblende crystallization based on experimental studies. Important factors are dissolved $\mathrm{H}_{2} \mathrm{O}$ in the magma and $\mathrm{Na}_{2} \mathrm{O}$ contents of at least 3 wt\% (Sisson and Grove, 1993a; Cawthorn and O'Hara, 1976). The explosive nature of Calbuco suggests that there is dissolved $\mathrm{H}_{2} \mathrm{O}$ in the magma, and high $\mathrm{H}_{2} \mathrm{O}$ contents are indicated by plagioclase phenocryst compositions (see discussion below). Whole rock analyses show that all eruptive products from Calbuco have $\mathrm{Na}_{2} \mathrm{O}$ higher than $3 \mathrm{wt} \%$, and glass trapped in plagioclase and pyroxene crystals, both phenocrysts and coarse grains in the cumulate xenoliths, predominantly have $\mathrm{Na}_{2} \mathrm{O} w \mathrm{wt} \%$ 
higher than $3 \%$. The conclusion that hornblende is a crystallizing phase is consistent with that of López-Escobar et al. (1995), who showed that the unusually high $\mathrm{SiO}_{2}$ contents relative to other oxides found in whole rock analyses of Calbuco lavas is consistent with approximately $30 \%$ fractionation of the crystallizing hornblende gabbro assemblage from the magma. Crystallization of hornblende will drive the residual liquid toward increased $\mathrm{SiO}_{2}$ relative to other oxides (Sisson and Grove, 1993a; Cawthorn and O’Hara, 1976; López-Escobar et al., 1995; Pichavant et al., 2002; Yagi and Takeshita, 1987; Allen and Boettcher, 1983; Foden and Green, 1992).

\section{1 a Are hornblende-bearing gabbroic xenoliths cognate cumulates?}

Coarse grained gabbroic xenoliths entrained in the lava from Calbuco are cognate cumulates. Evidence for this is: 1) gabbroic xenoliths have the same mineral assemblage as the phenocryst assemblage in the lavas (i.e. plagioclase, orthopyroxene, hornblende, magnetite, and rare clinopyroxene and olivine). Electron microprobe analysis of these phases shows that major element compositions overlap between respective coarse grain and phenocryst phases. 2) In general, the Mg-number ranges of the mafic phenocrysts and coarse grains also overlap, both within and between mineral phases, indicating that the crystals have crystallized from a similarly magnesian magma. These results contrast with those of Costa et al. (2002) for hornblende in gabbroic cumulate xenoliths in the eruptive products from Volcán San Pedro in Southern Chile. Hornblende Mg-numbers from phenocrysts and coarse grains in cumulate xenoliths are as high as those found by Costa, however, the $\mathrm{Cr}_{2} \mathrm{O}_{3} \mathrm{wt} \%$ of the hornblende is significantly lower and appropriate for equilibrium with Calbuco andesite. Results from this thesis are consistent with isotopic analyses of one cumulate xenolith. ${ }^{143} \mathrm{Nd} /{ }^{144} \mathrm{Nd}$ and ${ }^{87} \mathrm{Sr} /{ }^{86} \mathrm{Sr}$ values reported by 
Hickey-Vargas et al. (1995) also show that the gabbroic xenoliths are isotopically similar to lavas. Based on the striking compositional similarities between the mineral phases, whole rock analyses, and isotopes, the coarse grained gabbroic xenoliths are in fact cognate cumulates entrained in the magma. This conclusion is in agreement with Hickey-Vargas et al. (1995), Abdollahi (1990), McKelvey and Hickey-Vargas (2005), McKelvey and Hickey-Vargas (2004), and Horst and Hickey-Vargas (2006).

\subsection{How does hornblende break down?}

Two types of homblende breakdown reaction products can be observed in Calbuco lavas, a medium-grained "gabbroic type" and a microcrystalline "black type", which are similar with findings of Garcia and Jacobson (1979). I infer that opacite rims found on hornblende phenocrysts are similar to the microcrystalline "black type" reaction products. Gabbroic types also have patches of black microcrystalline reaction products which are associated with the coarser grains of plagioclase, pyroxene, and oxides. The "black type" reaction is found associated in varying degrees with all hornblende crystals in the eruptive products. Due to the fact that it has a microcrystalline texture, it is likely that it was formed as the result of rapid breakdown and therefore possibly contains mineral phases not in equilibrium with one another. This rapid breakdown is likely the result of eruption, although rapid degassing is another possibility.

Microprobe analysis of hornblende phenocrysts and coarse grains from cumulate xenoliths demonstrates that this breakdown is altering the composition of the hornblende crystal. As the hornblende breaks down, the reaction draws out elements such as Fe, Mg, $\mathrm{Ca}$, and $\mathrm{Al}$, faster than $\mathrm{Si}$. As a result, some pargasitic hornblende grains are even being altered to edenite, which has higher Si than pargasite. López-Escobar et al. (1995), and 
references therein, reported the presence of phenocrysts of both pargasite and edenite in the lava, however, the edenite is not crystallizing from the magma but is actually the result of phenocryst breakdown.

The mineral assemblage of the hornblende breakdown reaction for hornblende from Calbuco is:

Hbld $\rightarrow$ plag + opx $+\mathrm{cpx}+\mathrm{ol}+\operatorname{mag}( \pm$ ilmenite $) \pm \mathrm{V} \pm \mathrm{L}$

Noting the difficulty of analysis and the uncertainty of the breakdown mineral assemblage, an alternative reaction could be:

Hbld $\rightarrow$ plag + cpx + ol + mag $( \pm$ ilmenite $) \pm \mathrm{V} \pm \mathrm{L}$ with a subsequent simultaneous reaction of $\mathrm{Ol}+\mathrm{L} \rightarrow$ opx

These reactions are similar to those published for breakdown assemblages for hornblende from the Cascade Range, Calbuco, Soufrière Hills, Mount Pelée, Colima, and experimental products which include:

Amph $\rightarrow$ plag + cpx + opx + mag (Cascade Range; Garcia and Jacobson, 1979)

Hbld $\rightarrow$ plag + cpx + mag (Calbuco; López-Escobar et al., 1995)

Hbld $\rightarrow$ cpx + opx + plag + mag + melt (Soufrière Hills; Devine et al., 1998a, b)

Hbld $\rightarrow$ plag + opx + mag (Mount Pelée; Pichavant et al., 2002)

Amph $\rightarrow$ cpx + Fe-Ti oxide (Colima; Mora et al., 2002)

Amph $\rightarrow \mathrm{ol}+\mathrm{cpx}+\mathrm{plag}+\mathrm{L} \pm \mathrm{V}$ (experimental; Foden and Green, 1992) 


\subsection{What changes in magma chamber conditions are recorded in plagioclase zoning?}

Compositional zoning in plagioclase records magma chamber conditions. Plagioclase compositions and zoning in phenocrysts from Calbuco give evidence of equilibrium crystallization, the presence of water in the magma, eruption events, temperature fluctuations, convection within the magma chamber, and magma recharge.

\section{3a Evidence for Recharge}

Plagioclase crystals record the occurrence of recharge events within the magma chamber and subsequently record magma chamber temperature variations. Several lines of evidence for recharge occurring at Calbuco include An mol\% spikes in plagioclase zoning and correlating resorption textures, specifically types 2 and 3 oscillatory zoning, patchy zoning in phenocrysts, the presence of plagioclase megacrysts in the andesite, the presence of disequilibrium textures in plagioclase and minerals out of equilibrium with the andesite, and the presence of pigeonite microphenocrysts and rims in the basaltic andesite. Transects of plagioclase phenocrysts from Calbuco show that the crystals are normally zoned overall, but the crystals also have oscillatory zoning which records both An spikes of $10 \mathrm{~mol} \%$ or greater and drops of up to $37 \mathrm{An} \mathrm{mol} \%$. Type 1 oscillatory zoning (An mol\% fluctuations of 1-2 mol\% and occur without resorption surfaces) is not a result of magma mixing. Type 2 oscillatory zoning (An fluctuations of $2-5 \mathrm{~mol} \%$ without resorption) and type 3 oscillatory zoning (An fluctuations of up to $10 \mathrm{~mol} \%$ or higher with petrographically visible resorption surfaces) and patchy zoning all indicate temperature and compositional variations as a result of magma mixing.

Major element transects of the megacrysts show that they have unzoned, high An mol\% cores followed by a large decrease in An content connecting the unzoned, high An 
cores with the lower An, zoned rims. A few phenocrysts, although smaller is size, display the same profile pattern of an unzoned, high An core with a large, gradual An drop and a zoned rim. The unzoned nature of the core and the overall size of the megacrysts suggest that they have not crystallized in the same magma chamber as oscillatory zoned plagioclase, however the drop in An mol\% followed by the lower An, zoned rims suggest that they were introduced to the magma chamber prior to eruption.

Olivine, clinopyroxene, and hornblende crystals in the andesite are rare. Olivine and clinopyroxene have reaction textures indicating instability and hornblende is breaking down. López-Escobar et al. (1995) have suggested that olivine and clinopyroxene are early crystallizing phases which led to the formation of the low-MgO, high- $\mathrm{Al}_{2} \mathrm{O}_{3}$ parental magma, therefore they are likely to have crystallized at an earlier stage in the differentiation history of Calbuco; these minerals are largely introduced in the mafic mixing end member. Comparison of hornblende phenocrysts with partition coefficients for the exchange of $\mathrm{Al}-\mathrm{Si}$ and $\mathrm{Fe}-\mathrm{Mg}$ between the crystal and the magma from Sisson and Grove (1993a) shows that they have crystallized from the andesite. Pigeonite has a Mg-number range which is lower than orthopyroxene and olivine and is found in the basaltic andesite only as microphenocrysts and rims on olivine crystals. The low Mg-numbers and presence as thin rims and microphenocrysts are consistent with compositional variation from magma mixing.

\section{$8.3 b$ Evidence for the Presence of Water in the Magma}

The presence of dissolved water in Calbuco magma is borne out by 1) the crystallization of calcic plagioclase and its stability in the magma as reflected by partition coefficients for the exchange of $\mathrm{Ca}-\mathrm{Na}$ between plagioclase and hydrous melt, and 2) the 
crystallization of hornblende from the magma (discussed above). Cores of plagioclase phenocrysts, megacrysts, and coarse grains in cumulate gabbroic xenoliths are highly calcic $\left(\mathrm{An}_{58-92}, \mathrm{An}_{87-92}\right.$, and $\mathrm{An}_{56-97}$ respectively). Water initially enters subduction zone magmas as a result of dehydration of the subducting plate. This results in suppression of the plagioclase solidus (Figure 98, chapter 7) allowing highly calcic plagioclase to crystallize at lower temperatures that would be needed to stabilize the same An content in anhydrous magmas. In the case of Calbuco, water is also coming from contamination of the magma chamber with hydrous country rock (López-Escobar et al., 1995), and may also be coming from a subducted fracture zone beneath Calbuco (Sellés, 2004). In addition to the high An mol\% of the plagioclase, comparison with experimental exchange $\mathrm{Kd}$ values at various dissolved $\mathrm{H}_{2} \mathrm{O}$ amounts and various pressures from Sisson and Grove (2002a) (Figure 99, chapter 7) show that the cores of the three plagioclase populations above crystallized in the presence of water. Based on the experiments of Sisson and Grove (2002a), the phenocryst cores in the andesite and basaltic andesite and coarse grains in cumulate xenoliths are likely stable at pressures ranging from 1-5 kbars with 2-6 wt\% dissolved water at both saturated and undersaturated conditions. These experiments also show that the cores of the megacrysts in the andesite and basaltic andesite are likely stable at and above 2 kbars under water saturated conditions with $6^{+}$ wt $\%$ dissolved water. These same $\mathrm{Kd}$ values and the Ca-numbers of the zoned rims of both the phenocrysts and megacrysts in the andesite and basaltic andesite indicate that they may have crystallized under progressively lower pressure conditions (1-5 kbars, hydrous, to $1 \mathrm{~atm}$, anhydrous) or progressively lower dissolved water content (anhydrous to $6 \mathrm{wt} \%$ dissolved $\mathrm{H}_{2} \mathrm{O}$ ), or a more likely combination of both. 


\section{3c Evidence for Magma Chamber Convection}

Plagioclase phenocrysts, along with the overall mineral assemblage, are recording magma chamber convection through temperature, compositional, and dissolved water gradients in Calbuco andesite. That continuous convection occurred, in addition to episodic recharge and mixing, is indicated by the lack of correlation of An mol\% spikes between individual plagioclase phenocrysts. Evidence for either process is the coexistence of plagioclase crystals with disequilibrium textures, and other crystal phases out of equilibrium with the andesite. An mol\% spikes occur within plagioclase zoning as a result of temperature and dissolved water changes in the magma caused by recharge with hotter magma, and magma compositional changes as a result of recharge with basaltic andesite and fractional crystallization of the gabbroic mineral assemblage. Types 2 and 3 oscillatory zoning are prevalent in plagioclase phenocrysts, yet specific resorption events can not be correlated between crystals, in agreement with the findings of as also found by Ginibre et al. (2002b) at Parinacota volcano. On the scale of a single thin section, plagioclase crystals show both normal and reverse zoning in addition to sieve textures and resorption zones, indicating magma chamber convection. The mineral assemblage of Calbuco andesite contains minerals (orthopyroxene, clinopyroxene, and olivine) which are out of equilibrium with the andesite; basaltic andesite also contains pigeonite microphenocrysts and rims which are out of equilibrium with the basaltic andesite. The presence of disequilibrium textures is in agreement with the findings of Couch et al. (2001) for Soufrière Hills. 


\section{3d Evidence for Recorded Eruption Events}

Eruption or degassing events are recorded in plagioclase crystals as sudden, sharp An $\mathrm{mol} \%$ drops. Plagioclase crystallization is only affected by sudden, large scale fluctuations in pressure, such as a major degassing event or volcanic eruption. Sudden, sharp drops of up to $37 \mathrm{An}$ mol\% are seen in electron microprobe transects of plagioclase at the rim of one-third of the crystals, as well as a few drops of $12-24 \mathrm{An}$ mol\% found in the interior of some grains. The An mol\% drops within the crystal may record degassing of the volcano or prior eruption events, however, the location of the majority of the An drops at the outer rim, indicates that these crystals have likely recorded the eruption which brought them to the surface.

\section{3f Evidence for Equilibrium Crystallization}

Equilibrium crystallization of plagioclase is recorded in phenocrysts from Calbuco as type 1 oscillatory zoning. As plagioclase growth proceeds, it creates a cyclic pattern of depletion in $\mathrm{Ca}$ and $\mathrm{Na}$ in the surrounding magma which produces fine scale oscillatory zoning with An variation of 1-2 mol\%. At Calbuco the type 1 oscillatory zoning is overprinting with type 2 and 3 oscillatory zoning indicating that, with the open system magma chamber found at Calbuco, equilibrium crystallization is recorded in plagioclase but is not a dominant process. For Calbuco, equilibrium crystallization represents a return to magma homogenization after mixing and a hiatus from eruption events and local magmatic convection.

\subsection{Synthesis of Calbuco and the Magma Storage Zone}

Despite the zone of magma storage beneath Calbuco being an open system, the eruptive products have remained within a very narrow $\mathrm{SiO}_{2}$ range $(55-60 \mathrm{wt} \%$ ) over the 
life of the volcano. The magma storage zone below Calbuco is being fed by high- $\mathrm{Al}_{2} \mathrm{O}_{3}$, high-MgO basaltic magma similar to that from neighboring Osorno. This basalt evolves, most likely in a lower-crustal magma storage zone, by fractionating olivine, clinopyroxene, plagioclase and magnetite, resulting in a high- $\mathrm{Al}_{2} \mathrm{O}_{3}$, low-MgO basaltic magma and contributes to the calc-alkaline nature of the volcano. High-An plagioclase megacrysts crystallize from this high- $\mathrm{Al}_{2} \mathrm{O}_{3}$, low- $\mathrm{MgO}$ basalt as it cools slowly and differentiates to high- $\mathrm{Al}_{2} \mathrm{O}_{3}$, low-MgO basaltic andesite. Megacryst crystallization and differentiation to basaltic andesite may take place in a second, mid-crustal level magma storage zone because clinopyroxene has not been found in the basaltic andesite. Water enters Calbuco magma initially through dehydration of the subducting plate, and possibly also as a result of the subduction of a fracture zone directly beneath Calbuco. The rapid uplift rate beneath Calbuco further contaminates the magma, beginning at the basaltic andesite stage, with hydrous country rock, significantly adding to the dissolved $\mathrm{H}_{2} \mathrm{O}$ content of the magma. The magma storage zone where the andesite evolves is separate from the basaltic andesite storage zone, allowing the periodic recharge of the andesite with basaltic andesite. The $\mathrm{H}_{2} \mathrm{O}$ incorporated as a result of contamination, along with high $\mathrm{Na}_{2} \mathrm{O}$ contents, causes orthopyroxene and hornblende in the andesite, in addition to the magnetite and plagioclase which are still crystallizing, to begin to crystallize, at the expense of olivine and clinopyroxene. Crystallization of hornblende drives the residual magma toward higher $\mathrm{SiO}_{2}$ contents. Although the basaltic andesite also has elevated water contents from contamination and high $\mathrm{Na}_{2} \mathrm{O}$ contents, hornblende is not crystallizing due to temperatures above that which would stabilize hornblende. As crystallization is taking place in the andesitic magma chamber, fractionation is also 
occurring with crystals settling out of the magma. Cumulate piles of the fractionated assemblage (hornblende, orthopyroxene, plagioclase, and magnetite) are collecting at the base of the magma chamber. In addition to hornblende crystallization, fractionation of a mafic mineral assemblage and crustal contamination are also contributing to driving the residual magma toward higher $\mathrm{SiO}_{2}$ contents. Differentiation of the magma may drive the $\mathrm{SiO}_{2}$ content as high as a dacitic composition, and throughout the differentiation process the magma chamber has been subject to internal convection cells and continuous contamination with hydrous country rock, increasing the dissolved $\mathrm{H}_{2} \mathrm{O}$ content of the magma. To account for the fact that andesite is erupted rather than dacite, periodic inputs of fresh basaltic andesite from a mid-crustal magma chamber are mixing in with the differentiated magma causing fluctuations in temperature and dissolved $\mathrm{H}_{2} \mathrm{O}$ as well as once again lowering the $\mathrm{SiO}_{2}$ contents of the magma. Since the $\mathrm{SiO}_{2}$ range of all eruptive products is so narrow over a long period of time, the injections of basaltic andesite must be frequent and small; large inputs would likely cause more frequent eruptions, which would allow the eruptive products to sample the wider $\mathrm{SiO}_{2}$ range actually existing below Calbuco. Volcanic eruptions may be caused by periodic large injections of parental basalt, or by the build up of pressure from temperature and dissolved $\mathrm{H}_{2} \mathrm{O}$ fluctuations, or both. The crystallizing mineral assemblage in the andesitic upper magma chamber is plagioclase, orthopyroxene, magnetite, and hornblende, however the hornblende is only stable towards the bottom of the magma chamber where the pressure is high enough to sustain crystallization. Hornblende crystals are fractionated into cumulate piles a the bottom of the magma chamber without opacite rims present, indicating that they are stable, however, hornblende phenocrysts of the same composition as the fractionated 
hornblende which have been circulated to higher levels of the magma chamber, possibly through convection, have opacite rims and are therefore not stable. The mineral assemblage found in the andesite, which has an average density of $2.58 \mathrm{~g} / \mathrm{cm}^{3}$, is likely to be stable at temperatures of $810-975^{\circ} \mathrm{C}$ under pressure of 2 kbars and less with up to 6 wt\% dissolved $\mathrm{H}_{2} \mathrm{O}$. The mineral assemblage of the basaltic andesite, which has a density of $2.61 \mathrm{~g} / \mathrm{cm}^{3}$, is likely to be stable at temperature above $975^{\circ} \mathrm{C}$ and pressures of greater than 2 kbars with $6+$ wt $\%$ dissolved $\mathrm{H}_{2} \mathrm{O}$. 


\section{References}

Abdollahi, M.J., 1990. Petrological and geochemical study of crustal xenoliths from Calbuco Volcano, Chile (latitude $41^{\circ} 20^{\prime} \mathrm{S}$ ). Master's thesis, Florida International University.

Allen, J.C. and Boettcher, A.L., 1978. Amphiboles in andesite and basalt: II. Stability as a function of $P-T-f \mathrm{H}_{2} \mathrm{O}-f \mathrm{O}_{2}$. American Mineralogist, vol. 63, p. 1074-1087.

Allen, J.C. and Boettcher, A.L., 1983. The stability of amphibole in andesite and basalt at high pressures. American Mineralogist, vol. 68, p. 307-314.

Amma-Miyasaka, M. and Nakagawa, M., 2002. Origin of anorthite and olivine megacrysts in island-arc tholeiites: petrological study of 1940 and 1962 ejecta from Miyake-Jima Volcano, Izu-Mariana arc. Journal of Volcanology and Geothermal Research, vol. 117, p. 263-283.

Amma-Miyasaka, M. and Nakagawa, M., 2003. Evolution of deeper basaltic and shallower andesitic magmas during the AD 1469-1983 eruptions of Miyake-Jima Volcano, Izu-Mariana arc: inferences from temporal variations of mineral compositions in crystal-clots. Journal of Petrology, vol. 44, no. 12, p. 2113-2138.

Anderson, A.T., 1980. Significance of hornblende in calc-alkaline andesites and basalts. American Mineralogist, vol. 65, p. 837-851.

Anderson, D.J. and Lindsley, D.H., 1988. Internally consistent solution models for FeMg-Mn-Ti oxides: Fe-Ti oxides. American Mineralogist, vol. 73, p. 714-726.

Aslan, Z., 2005. Petrography and petrology of the calc-alkaline Sarihan Granitoid (NE Turkey): an example of magma mingling and mixing. Turkish Journal of Earth Sciences, vol. 14, p. 185-207.

Barclay, J., Rutherford, M.J., Carroll, M.R., Murphy, M.D., Devine, J.D., Gardner, J., and Sparks, R.S.J., 1998. Experimental phase equilibria constraints on pre-eruptive storage conditions of the Soufrière Hills magma. Geophysical Research Letters, vol. 25 , no. 18 , p. $3437-3440$.

Barclay, J. and Carmichael, I.S.E., 2004. A hornblende basalt from Western Mexico: Water-saturated phase relations constrain a pressure-temperature window of eruptibility. Journal of Petrology, vol. 45, no. 3, p. 485-506.

Beard, J.S., 1986. Characteristic mineralogy of arc-related cumulate gabbros: implications for the tectonic setting of gabbroic plutons and for andesite genesis. Geology, vol. 14, p. 848-851.

Beard, J.S. and Lofgren, G.E., 1992. An experiment-based model for the petrogenesis of high-alumina basalts. Science, vol. 258, p.112-114. 
Bindeman, I.N. and Bailey, J.C., 1999. Trace elements in anorthite megacrysts from the Kurile Island Arc: a window to across-arc geochemical variation in magma compositions. Earth and Planetary Science Letters, vol. 169, p. 209-226.

Bindeman, I.N., Davis, A.M., and Drake, M.J., 1998. Ion microprobe study of plagioclase-basalt partition experiments at natural concentration levels of trace elements. Geochimica et Cosmochimica Acta, vol. 62, no. 7, p. 1175-1193.

Blundy, J.D., and Shimizu, N., 1991. Trace element evidence for plagioclase recycling in calc-alkaline magmas. Earth and Planetary Science Letters, vol. 102, p. 178-197.

Blundy, J.D. and Wood, B.J., 1991. Crystal-chemical controls on the partitioning of Sr and $\mathrm{Ba}$ between plagioclase feldspar, silicate melts, and hydrothermal solutions. Geochimica et Cosmochimica Acta, vol. 55, p. 193-209.

Blundy, J. and Wood, B., 2003. Partitioning of trace elements between crystals and melts. Earth and Planetary Science Letters, vol. 210, p. 383-397.

Bottinga, Y., Kudo, A., and Weill, D., 1966. Some observations on oscillatory zoning and crystallization of magmatic plagioclase. American Mineralogist, vol. 51, p. 792-806.

Brophy, J.G., Dorais, M.J., Donnelly-Nolan, J., and Singer, B.S., 1996. Plagioclase zonation styles in hornblende gabbro inclusions from Little Glass Mountain, Medicine Lake Volcano, California: implications for fractionation mechanisms and the formation of composition gaps. Contributions to Mineralogy and Petrology, vol. 126, p. 121-136.

Bryan, W.B., 1974. Fe-Mg relationships in sector-zoned submarine basalt plagioclase. Earth and Planetary Science Letters, vol. 24, p. 157-165.

Castro, A. and Stephens, W.E., 1992. Amphibole-rich polycrystalline clots in calcalkaline granitic rocks and their enclaves. Canadian Mineralogist, vol. 30, p. 1093-1112.

Cawthorn, R.G., 2002. Delayed accumulation of plagioclase in the Bushveld Complex. Mineralogical Magazine, vol. 66, no. 6, p. 881-893.

Cawthorn, R.G. and O'Hara, M.J., 1976. Amphibole fractionation in calc-alkaline magma genesis. American Journal of Science, vol. 276, p. 309-329.

Cembrano, J., Hervé, F., and Lavenu, A., 1996. The Liquiñe-Ofqui fault zone: a longlived intra-arc fault system in southern Chile. Tectonophysics, vol. 259, p. 55-66.

Cembrano, J., Schermer, E., Lavenu, A., and Sanhueza, A., 2000. Contrasting nature of deformation along an intra-arc shear zone, the Liquiñe Ofqui fault zone, southern Chilean Andes. Tectonophysics, vol. 319, p. 129-149. 
Choe, W. and Jwa, Y., 2004. Petrological and geochemical evidences for magma mixing in the Palgongsan Pluton. Geosciences Journal, vol. 8, no. 4, p. 343-354.

Costa, F., Dungan, M.A., and Singer, B.S., 2002. Hornblende- and phlogopite-bearing gabbroic xenoliths from Volcán San Pedro $\left(36^{\circ} \mathrm{S}\right)$, Chilean Andes: Evidence for melt and fluid migration and reactions in subduction-related plutons. Journal of Petrology, vol. 43, no. 2, p. 219-241.

Costa, F., Chakraborty, S., and Dohmen, R., 2003. Diffusion coupling between trace and major elements and a model for calculation of magma residence times using plagioclase. Geochimica et Cosmochimica Acta, vol. 67, no. 12, p. 2189-2200.

Couch, S., Harford, C.L., Sparks, R.S.J., and Carroll, M.R., 2003a. Experimental constraints on the conditions of formation of highly calcic plagioclase microlites at the Soufrière Hills volcano, Montserrat. Journal of Petrology, vol. 44, no. 8, p. $1455-1475$.

Couch, S., Sparks, R.S.J., and Carroll, M.R., 2001. Mineral disequilibrium in lavas explained by convective self-mixing in open magma chambers. Nature, vol. 411 , p. 1037-1039.

Couch, S., Sparks, R.S.J., and Carroll, M.R., 2003b. The kinetics of degassing-induced crystallization at Soufrière Hills Volcano, Montserrat. Journal of Petrology, vol. 44 , no. 8 , p. $1477-1502$.

Deer, W.A., Howie, R.A., and Zussman, J., 1966. An introduction to the rock-forming minerals. Longmans, Green and Co, Limited, London.

Devine, J.D., Murphy, M.D., Rutherford, M.J., Barclay, J., Sparks, R.S.J., Carroll, M.R., Young, S.R., and Gardner, J.E., 1998a. Petrologic evidence for pre-eruptive pressure-temperature conditions, and recent reheating, of andesitic magma erupting at the Soufrière Hills Volcano, Montserrat, W.I. Geophysical Research Letters, 25, 19, 3669-3672.

Devine, J.D., Rutherford, M.J., and Gardner, J.E., 1998b. Petrologic determination of ascent rates for the 1995-1997 Soufrière Hills Volcano andesitic magma. Geophysical Research Letters, vol. 25, no. 19, p. 3673-3676.

Devine, J.D., Rutherford, M.J., Norton, G.E., and Young, S.R., 2003. Magma storage region processed inferred from geochemistry of $\mathrm{Fe}-\mathrm{Ti}$ oxides in andesitic magma, Soufrière Hills Volcano, Montserrat, W.I. Journal of Petrology, vol. 44, no. 8, p. $1375-1400$.

Dostal, J., Dupuy, C., Carron, J.P., Le Guen de Kerneizon, M., and Maury, R.C., 1983. Partition coefficients of trace elements; application to volcanic rocks of St. 
Vincent, West Indies. Geochimica et Cosmochimica Acta, vol. 47, no. 3, p. 525533.

Droop, G.T.R., 1987. A general equation for estimating $\mathrm{Fe}^{3+}$ concentrations in ferromagnesian silicates and oxides from microprobe analyses, using stoichiometric criteria. Mineralogical Magazine, vol. 51, p. 431-435.

Fichaut, M., Marcelot, G., and Clocchiatti, R., 1989. Magmatology of Mt. Pelée (Martinique, F.W.I.). II: petrology of gabbroic and dioritic cumulates.

Foden, J.D. and Green, D.H., 1992. Possible role of amphibole in the origin of andesite: some experimental and natural evidence. Contributions to Mineralogy and Petrology, vol. 109, p. 479-493.

Gaetani, G.A., Grove, T.L., and Bryan, W.B., 1993. The influence of water on the petrogenesis of subduction related igneous rocks. Nature, vol. 365, p. 332-334.

Garcia, M.O. and Jacobson, S.S., 1979. Crystal clots, amphibole fractionation and the evolution of calc-alkaline magmas. Contribution to Mineralogy and Petrology, vol. 69 , p. $319-327$.

Gardner, J.E., Rutherford, M., Carey, S., and Sigurdsson, H., 1995. Experimental constraints on pre-eruptive water contents and changing storage prior to explosive eruptions of Mount St. Helens Volcano. Bulletin of Volcanology, vol. 57, p. 117.

Ghiorso, M.S. and Evans, B.W., 2002. Thermodynamics of the amphiboles: CA-Mg$\mathrm{Fe}^{2+}$ quadrilateral. American Mineralogist, vol. 87, no. 1, p. 79-98.

Ginibre, C., Kronz, A., and Wörner, G., 2002a. High-resolution quantitative imaging of plagioclase composition using accumulated backscattered electron images: new constraints on oscillatory zoning. Contributions to Mineralogy and Petrology, vol. 142 , p. $436-448$.

Ginibre, C., Wörner, G., and Kronz, A., 2002b. Minor- and trace-element zoning in plagioclase: implications for magma chamber processes at Parinacota Volcano, northern Chile. Contributions to Mineralogy and Petrology, vol. 143, p. 300-315.

Ginibre, C., Wörner, G., and Kronz, A., 2004. Structure and dynamics of the Laacher See magma chamber (Eifel, Germany) from major and trace element zoning in Sanidine: a cathodoluminescence and electron microprobe study. Journal of Petrology, vol. 45, no. 11, p. 2197-2223.

Green, T.H. and Ringwood, A.E., 1967. Crystallization of basalt and andesite under high pressure hydrous conditions. Earth and Planetary Science Letters, vol. 3, p. 481489. 
Grove, T.L., 1993. Corrections to expressions for calculation mineral components in "origin of calc-alkaline series lavas at Medicine Lake Volcano by fractionation, assimilation and mixing" and "experimental petrology of normal MORB near the Kane Fracture Zone: $22^{\circ}-25^{\circ} \mathrm{N}$, mid-Atlantic ridge". Contributions to Mineralogy and Petrology, vol. 114, p. 422-424.

Grove, T.L. and Baker, M.B., 1983. Effects of melt density on magma mixing in calcalkaline series lavas. Nature, vol. 305, no. 5933, p. 416-418.

Grove, T.L. and Baker, M.B., 1984. Phase equilibrium controls on the tholeiitic versus calc-alkaline differentiation trends. Journal of Geophysical Research, vol. 89, no. B5, p. 3253-3274.

Grove, T.L., Baker, M.B., and Kinzler, R.J., 1984. Coupled CaAl-NaSi diffusion in plagioclase feldspar: experiments and applications to cooling rate speedometry. Geochimica et Cosmochimica Acta, vol. 48, p. 2113-2121.

Grove, T.L., Elkins-Tanton, L.T., Parman, S.W., Chatterjee, N., Muntener, O., and Gaetani, G.A., 2003. Fractional crystallization and mantle-melting controls on calc-alkaline differentiation trends. Contributions to Mineralogy and Petrology, vol. 145, p. 515-533.

Grove, T.L., Gerlach, D.C., and Sando, T.W., 1982. Origin of calc-alkaline series lavas at Medicine Lake Volcano by fractionation, assimilation and mixing. Contributions to Mineralogy and Petrology, vol. 80, p. 160-182.

Grove, T.L., Gerlach, D.C., Sando, T.W., and Baker, M.B., 1983. Origin of calc-alkaline series lavas at Medicine Lake Volcano by fractionation, assimilation and mixing: corrections and clarifications. Contributions to Mineralogy and Petrology, vol. 82 , p. $407-408$.

Hammarstrom, J. and Zen, E., 1986. Aluminum in hornblende: an empirical igneous geobarometer. American Mineralogist, vol. 71, p. 1297-1313.

Hammer, J.E. and Rutherford, M.J., 2002. An experimental study of the kinetics of decompression-induced crystallization in silicic melt. Journal of Geophysical Research, vol. 107, no. BI, p. 2021.

Hattori, K. and Sato, H., 1996. Magma evolution recorded in plagioclase zoning in 1991 Pinatubo eruption products. American Mineralogist, vol. 81, p. 982-994.

Hickey, R. L., Gerlach, D.C., and Frey, F. A., 1984. Geochemical Variations in Volcanic Rocks from Central-South Chile (33-42 S). In: Andean Magmatism Chemical and Isotopic Constraints, (Eds. R. S. Harmon and B. A. Barreiro), p. 72-95; Shiva Publishing Limited, UK. 
Hickey-Vargas, R., Abdollahi, M.J., Parada, M.A., López-Escobar, L., and Frey, F.A., 1995. Crustal xenoliths from Calbuco Volcano, Andean Southern Volcanic Zone: implications for crustal composition and magma-crust interaction. Contributions to Mineralogy and Petrology, vol. 119, p. 331-344.

Higgins, M.D., 2000. Measurement of crystal size distributions. American Mineralogist, vol. 85 , p. $1105-1116$.

Higgins, M.D. and Roberge, J., 2003. Crystal size distribution of plagioclase and amphibole from Soufrière Hills Volcano, Montserrat: evidence for dynamic crystallization-textural coarsening cycles. Journal of Petrology, vol. 44, no. 8, p. 1401-1411.

Hochstaedter, A.G., Kepezhinskas, P. and Defant, M., 1996. Insights into the volcanic arc mantle wedge from magnesian lavas from the Kamchatka arc. Journal of Geophysical Research, vol. 101, no. B1, p. 697-712.

Holland, T. and Blundy, J., 1994. Non-ideal interactions in calcic amphiboles and their bearing on amphibole-plagioclase thermometry. Contributions to Mineralogy and Petrology, vol. 116, p. 433-447.

Holten, T., Jamtveit, B., Meakin, P., Cortini, M., Blundy, J., and Austrheim, H., 1997. Statistical characteristics and origin of oscillatory zoning in crystals. American Mineralogist, vol. 82, p. 596-606.

Horst, T. and Hickey-Vargas, R., 2006. Magmatic Processes Contributing to the Explosive Nature of Calbuco Volcano in Southern Chile. Poster Session Abstract, AAPG Student Expo.

Izbekov, P.E., Eichelberger, J.C., Patino, L.C., Vogel, T.A., and Ivanov, B.V., 2002. Calcic cores of plagioclase phenocrysts in andesite from Karymsky Volcano: evidence for rapid introduction by basaltic replenishment. Geology, vol. 30, no. 9, p. 799-802.

Johnson, M.C. and Rutherford, M.J., 1989. Experimental calibration of the aluminum-inhormblende geobarometer with application to Long Valley caldera (California) volcanic rocks. Geology, vol. 17, p. 837-841.

Karsli, O., Aydin, F., and Sadiklar, M.B., 2004. Magma interaction recorded in plagioclase zoning in granitoid systems, Zigana Granitoid, Eastern Pontides, Turkey. Turkish Journal of Earth Sciences, vol. 13, p. 287-305.

Kawamoto, T., 1996. Experimental constraints on differentiation and $\mathrm{H}_{2} \mathrm{O}$ abundances of calc-alkaline magmas. Earth and Planetary Science Letters, vol. 144, p. 577-589. 
Kuritani, T., 1998. Boundary layer crystallization in a basaltic magma chamber: evidence from Rishiri Volcano, northern Japan. Journal of Petrology, vol. 39, no. 9, p. 1619-1640.

Klohn, E., 1963. The February 1961 eruption of Calbuco Volcano. Bulletin of the Seismological Society of America, vol. 53, no. 6, p. 1435-1436.

Lavenu, A. and Cembrano, J., 1999. Compressional- and transpressional-stress pattern for Pliocene and Quaternary brittle deformation in fore arc and intra-arc zones (Andes of Central and Southern Chile). Journal of Structural Geology vol. 21, p. 1669-1691.

Leake, B.E., Woolley, A.R., Arps, C.E.S., Birch, W.D., Gilbert, M.C., Grice, J.D., Hawthorne, F.C., Kato, A., Kisch, H.J., Krivovichev, V.G., Linthout, K., Laird, J., Mandarino, J.A., Maresch, W.V., Nickel, E.H., Rock, N.M.S., Schumcher, J.C., Smith, D.C., Stephenson, N.C.N., Ungaretti, L., Whittaker, E.J.W., and Youzhi, G., 1997. Nomenclature of amphiboles: Report of the subcommittee on amphiboles of the International Mineralogical Association, Commission on New Minerals and Mineral Names. American Mineralogist, vol. 82, p. 10191037.

Lindsley, D.H., 1983. Pyroxene thermometry. American Mineralogist, vol. 68, p. 477493.

Lindsley, D.H. and Anderson, D.J., 1983. A two-pyroxene thermometer. Journal of Geophysical Research, vol. 88, supplement, p. A887-A906.

Longhi, J., Walker, D., and Hays, J.F., 1976. Fe and Mg in plagioclase. Proceedings of the $7^{\text {th }}$ Lunar Science Conference, p.1281-1300.

López-Escobar, L., 1984. In: Andean Magmatism Chemical and Isotopic Constraints, (Eds. R. S. Harmon and B. A. Barreiro), p. 72-95; Shiva Publishing Limited, UK.

López-Escobar, L. and Parada, M.A., 1991. Diferencias geoquimicas y petrograficas entre los volcanes vecinos, Calbuco y Osorno, y Centros Eruptivos Menores, Andes del sur, $41-42^{\circ} \mathrm{S}$, Chile. In Congreso Geologico Chileno, Resumenes Ampliados, p.27-29.

López-Escobar, L., Parada, M., Hickey-Vargas, R., Frey, F., Kempton, P., and Moreno, H., 1995. Calbuco Volcano and minor eruptive centers distributed along the Liquiñe-Ofqui Fault Zone, Chile $\left(41^{\circ}-42^{\circ} \mathrm{S}\right)$ : contrasting origin of andesitic and basaltic magma in the Southern Volcanic Zone of the Andes. Contributions to Mineralogy and Petrology vol. 119, p. 345-361.

López-Escobar, L., Parada, M.A., Moreno, H., Frey, F.A., and Hickey-Vargas, R.L., 1992. A contribution to the petrogenesis of Osorno and Calbuco Volcanoes, 


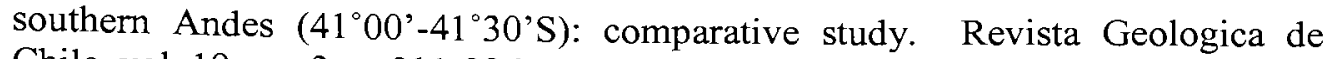
Chile, vol. 19, no. 2, p. 211-226.

Luhr, J.F., 2002. Petrology and geochemistry of the 1991 and 1998-1999 lava flows from Volcán de Colima, México: implications for the end of the current eruptive cycle. Journal of Volcanology and Geothermal Research, vol. 117, p. 169-194.

Luhr, J.F. and Carmichael, I.S.E., 1980. The Colima volcanic complex, Mexico; I. postcaldera andesites from Volcán Colima. Contributions to Mineralogy and Petrology, vol. 71, no. 4, p.343-372.

Marsh, B.D., 1995. Solidification fronts and magmatic evolution (the 1995 Hallimond lecture). Mineralogical Magazine, vol. 60, p. 5-40.

Martel, C., Pichavant, M., Holtz, F., and Scaillet, B., 1999. Effects of $f \mathrm{O}_{2}$ and $\mathrm{H}_{2} \mathrm{O}$ on andesite phase relations between 2 and 4 kbar. Journal of Geophysical Research, vol. 104, no. B12, p. 29453-29470.

McKelvey, T. and Hickey-Vargas, R., 2004. The andesites of Calbuco Volcano: crystal compositions and textures. Poster Session Abstract, IAVCEI General Assembly.

McKelvey, T. and Hickey-Vargas, R., 2005. Plagioclase crystal populations in lavas from Calbuco Volcano, Chile. Poster Session Abstract, AGU Fall Meeting.

Moore, G. and Carmichael, I.S.E., 1998. The hydrous phase equilibria (to $3 \mathrm{kbar}$ ) of an andesite and basaltic andesite from western Mexico: constraints on water content and conditions of phenocryst growth. Contributions to Mineralogy and Petrology, vol. 130, p. 304-319.

Mora, J.C., Macias, J.L., Saucedo, R., Orlando, A., Manetti, P., and Vaselli, O., 2002. Petrology of the 1998-2002 products of Volcán de Colima, Mexico. Journal of Volcanology and Geothermal Research, vol. 117, p. 195-212.

Moreno-Roa, H., López-Escobar, L., and Naranjo, J.A., 2004. Field trip guide C-4, Osorno and Calbuco Volcanoes. IAVCEI General Assembly.

Morimoto, N., Fabries, J., Ferguson, A.K., Ginzburg, I.V., Ross, M., Seifert, F.A., Zussman, J., Aoki, K., and Gottardi, G., 1988. Nomenclature of pyroxenes. American Mineralogist, vol. 73, p. 1123-1133.

Murphy, M.D., Sparks, R.S.J., Barclay, J., Carroll, M.R., Lejeune, A-M., Brewer, T.S., Macdonald, R., Black, S., and Young, S., 1998. The role of magma mixing in triggering the current eruption at the Soufrière Hills Volcano, Montserrat, West Indies. Geophysical Research Letters, vol. 25, no. 18, p. 3433-3436.

Nesse, W.D., 2000. Introduction to mineralogy. Oxford University Press, New York. 
Nixon, G.T. and Pearce, T.H., 1987. Laser-interferometry study of oscillatory zoning in plagioclase: the record of magma mixing and phenocryst recycling in calcalkaline magma chambers, Iztaccíhuatl Volcano, Mexico. American Mineralogist, vol. 72, p. 1144-1162.

Ochs, F.A. and Lange, R.A., 1999. The density of hydrous magmatic liquids. Science, vol. 283, p. 1314-1317.

Pallister, J.S., Hoblitt, R.P., Meeker, Gregory, P., Knight, R.J., and Siems, D. F., 1996. Magma mixing at Mount Pinatubo: petrographic and chemical evidence from the 1991 deposits. U.S. Geological Survey.

Panjasawatwong, Y., Danyusheversusky, L.D., Crawford, A.J., and Harris, K.L., 1995. An experimental study of the effects of melt composition on plagioclase-melt equilibria at 5 and $10 \mathrm{kbar}$ : implications for the origin of magmatic high-An plagioclase. Contributions to Mineralogy and Petrology, vol. 118, p. 420-432.

Parada, M.A., 1990. Composicion de fenocristales en lavas del Volcán Calbuco y sus implicancias en la historia temprana de cristalizacion. Actas XI Congreso Geologico Argentino vol. 1, p. 101-104.

Parada, M.A., Godoy, E., Hervé, F., and Thiele, R., 1987. Miocene calc-alkaline plutonism in the Chilean southern Andes. International Symposium on Granites and Associated Mineralization (ISAGM), Salvador, Brasil Geociencias, vol. 17, no. 4 , p. $450-455$.

Pearce, T.H., Russel, J.K., and Wolfson, I., 1987. Laser-interference and Nomarski interference imaging of zoning profiles in plagioclase phenocrysts from the May 18, 1980, eruption of Mount St. Helens, Washington. American Mineralogist, vol. 72, p. 1131-1143.

Peters, M.T., Shaffer, E.E., Burnett, D.S., and Kim, S.S., 1995. Magnesium and titanium partitioning between anorthite and type B CAI liquid: dependence on oxygen fugacity and liquid composition. Geochimica et Cosmochimica Acta, vol. 59, no. 13, p. 2785-2796.

Pichavant, M., Martel, C., Bourdier, J., and Scaillet, B., 2002. Physical conditions, structure, and dynamics of a zoned magma chamber: Mount Pelée (Martinique, Lesser Antilles arc). Journal of Geophysical Research, vol. 107, no. B5, 2093.

Philpotts, A.R., 1990. Principles of igneous and metamorphic petrology. Prentice Hall, New Jersey.

Phinney, W.C., 1992. Partition coefficients for iron between plagioclase and basalt as a function of oxygen fugacity: implications for Archean and lunar anorthosites. Geochimica et Cosmochimica Acta, vol. 56, p. 1885-1895. 
Price, R.C., Gamble, J.A., Smith, I.E.M., Stewart, R.B., Eggins, S., and Wright, I.C., 2005. An integrated model for the temporal evolution of andesites and rhyolites and crustal development in New Zealand's North Island. Journal of Volcanology and Geothermal Research, vol. 140, p. 1-24.

Rodriquez-Durand, S. and Sen, G., 2004. Preeruption history of the Grande Ronde Formation lavas, Columbia River Basalt Group, American Northwest: Evidence from phenocrysts. Geology, vol. 32, no. 4, p. 293-296.

Rutherford, M.J. and Devine, J.D., 1998a. Changing magma conditions and ascent rates during the Soufrière Hills eruption on Montserrat. GSA Today, vol. 8, no. 3.

Rutherford, M.J. and Devine, J.D., 1998b. The May 18, 1980, eruption of Mount St. Helens 3. stability and chemistry of amphibole in the magma chamber. Journal of Geophysical Research, vol. 93, no. B10, p. 11949-11595.

Rutherford, M.J. and Devine, J.D., 2003. Magmatic conditions and magma ascent as indicated by hornblende phase equilibria and reactions in the 1995-2002 Soufrière Hills magma. Journal of Petrology, vol. 44, no. 8, p. 1433-1454.

Sail, A.N., Ferreira, V.P., Fallick, A.E., and Jeronimo, M., 1998. Amphibole-rich clots in calc-alkaline granitoids in the Borborema province, northeastern Brazil. Journal of South American Earth Sciences, vol. 11, no. 5, p. 457-471.

Sato, H., 1989. Mg-Fe partitioning between plagioclase and liquid in basalts of Hole 504B, ODP LEG 111: a study of melting at $1 \mathrm{~atm}$. Proceedings of the Ocean Drilling Program, Scientific Results, vol. 111, p. 17-26.

Scarfe, C.M. and Fujii, T., 1987. Petrology of crystal clots in the pumice of Mount St. Helens' March 19, 1982 eruption; significant role of Fe-Ti oxide crystallization. Journal of Volcanology and Geothermal Research, vol. 34, p. 1-14.

Schmincke, H., 2004. Volcanism. Springer-Verlag, Berlin.

Shelly, D., 1993. Igneous and metamorphic rocks under the microscope; classifications, textures, microstructures, and mineral preferred orientations. Chapman and Hall, London.

Shore, M. and Fowler, A.D., 1996. Oscillatory zoning in minerals: a common phenomenon. Canadian Mineralogist, vol. 34, p. 1111-1126.

Sellés, D., Rodriguez, C., and Dungan, M.A., 2004. Amphibole fractionation from water-rich magmas and the incompatible element-poor nature of Nevado do Longavi magmas (Andean SVZ). Symposium Abstract, IAVCEI General Assembly. 
Singer, B.S., Dungan, M.A., and Layne, G.D., 1995. Textures and Sr, Ba, Mg, Fe, K, and Ti compositional profiles in volcanic plagioclase: clues to the dynamics of calcalkaline magma chambers. American Mineralogist, vol. 80, p. 776-798.

Singer, B.S. and Pearce, T.H., 1993. Plagioclase zonation in a basalt to rhyodacite eruptive suite, Seguam Island, Alaska: observations by Nomarski contrast interference. Canadian Mineralogist, vol. 31, p. 459-466.

Singer, B.S., Pearce, T.H., Kolisnik, A.M., and Myers, J.D., 1993. Plagioclase zoning in mid-Pleistocene lavas from the Seaguam volcanic center, central Aleutian arc, Alaska. American Mineralogist, vol. 78, p. 143-157.

Sisson, T.W., 1994. Hornblende-melt trace element partitioning measured by ion microprobe. Chemical Geology, vol. 117, no. 1-4, p. 331-344.

Sisson, T.W. and Grove, T.L., 1993a. Experimental investigations of the role of $\mathrm{H}_{2} \mathrm{O}$ in calc-alkaline differentiation and subduction zone magmatism. Contributions to Mineralogy and Petrology, vol. 113, p. 143-166.

Sisson, T.W. and Grove, T.L., 1993b. Temperatures and $\mathrm{H}_{2} \mathrm{O}$ contents of low-MgO high-alumina basalts. Contributions to Mineralogy and Petrology, vol. 113, p. 167-184.

Spencer, K.J. and Lindsley, D.H., 1981. A solution model for coexisting iron-titanium oxides. American Mineralogist, vol. 66, p. 1189-1201.

Stamatelopoulou-Seymour, K., Vlassopoulos, D., Pearce, T.H., and Rice, C., 1990. The record of magma chamber processes in plagioclase phenocrysts at Thera Volcano, Aegean volcanic arc, Greece. Contributions to Mineralogy and Petrology, vol. 104, p. 73-84.

Stern, R.J., 2002. Subduction zones. Reviews of Geophysics, vol. 40, no. 4, p. 3-1 - 338.

Stewart, D.C., 1975. Crystal clots in calc-alkaline andesites as breakdown products of high-Al amphiboles. Contributions to Mineralogy and Petrology, vol. 53, p. 195204.

Stewart, M.L. and Fowler, A.D., 2001. The nature and occurrence of discrete zoning in plagioclase from recently erupted andesitic volcanic rocks, Montserrat. Journal of Volcanology and Geothermal Research, vol. 106, p. 243-253.

Stormer, J.C., 1983. The effects of recalculation on estimates of temperature and oxygen fugacity from analyses of multicomponent iron-titanium oxides. American Mineralogist, vol. 68, p. 586-594. 
Sugawara, T., 2001. Ferric iron partitioning between plagioclase and silicate liquid: thermodynamics and petrological applications. Contributions to Mineralogy and Petrology, vol. 141, p. 659-686.

Tormey, D.R., Grove, T.L., and Bryan, W.B., 1987. Experimental petrology of normal MORB near the Kane Fracture Zone: $22^{\circ}-25^{\circ} \mathrm{N}$, mid-Atlantic ridge. Contributions to Mineralogy and Petrology, vol. 96, p. 121-139.

Tormey, D.R., Hickey-Vargas, R., Frey, F.A., and López-Escobar, L, 1991. Recent lavas from the Andean volcanic front (33 to $\left.42^{\circ} \mathrm{S}\right)$; interpretations of along-arc compositional variations. In: Andean Magmatism and its Tectonic Setting, (Eds. R.S. Harmon and C.W. Rapela), p.57-77; The Geological Society of America, Colorado.

Thorpe, R. S., 1984. The Tectonic Setting of Active Andean Volcanism. In: Andean Magmatism Chemical and Isotopic Constraints, (Eds. R. S. Harmon and B. A. Barreiro), p.4-8; Shiva Publishing Limited, UK.

Vance, J.A., 1962. Zoning in igneous plagioclase: normal and oscillatory zoning. American Journal of Science, vol. 260, p. 746-760.

Wilke, M. and Behrens, H., 1999. The dependence of the partitioning of iron and europium between plagioclase and hydrous tonalitic melt on oxygen fugacity. Contributions to Mineralogy and Petrology, vol. 137, p. 102-114.

Yagi, K. and Takeshita, H., 1987. Impact of hornblende crystallization for the genesis of calc-alkaline andesites. Magmatic Processes: Physiochemical Properties. In: The Geochemical Society, Special Publications No. 1, (Ed. B.O. Mysen) p.183-190.

Zellmer, G.F., Sparks, R.S.J., Hawkesworth, C.J., and Wiedenbeck, M., 2003. Magma emplacement and remobilization timescales beneath Montserrat: insights from $\mathrm{Sr}$ and $\mathrm{Ba}$ zonation in plagioclase phenocrysts. Journal of Petrology, vol. 44, no. 8, p. 1413-1431. 


\section{List of Appendices on CD}

Appendix A: $\quad$ Global Volcanism Program-Calbuco-Eruptive History

Laser Ablation Report from the Chemistry Department

Appendix B: $\quad$ Electron Microprobe Data for Coarse Grains in Gabbroic Xenoliths

Electron microprobe Data for Minerals in Crystal Clusters

Electron Microprobe Data for Phenocrysts in Andesite and Basaltic

Andesite

Appendix C: $\quad$ Electron Microprobe Data for Hornblende and Associated

Breakdown Phases

Appendix D: $\quad$ Electron Microprobe Data-Major, Minor, and Trace Element

Transects

Electron Microprobe Major Element Transect Plots of Plagioclase

Electron Microprobe Trace Element Transect Plots of Plagioclase

Major and Trace Element Transect Plots Showing An mol\%

Spikes

Major Element Transect Plots Showing Resorption and Growth

Zones 